MARIA ALEXANDRE DE OLIVEIRA

\title{
A Literatura para crianças e jovens no Brasil de ontem e de hoje: caminhos de Ensino
}

Tese apresentada à Faculdade de Educação da Universidade de São Paulo para obtenção do título de Doutor em Didática

Área de Concentração: Didática, Teorias de Ensino e Práticas Escolares

Orientadora: Prof ${ }^{a} \mathrm{Dr}^{\mathrm{a}}$ Heloísa Dupas de Oliveira Penteado. 


\section{FOLHA DE APROVAÇÃO}

Maria Alexandre de Oliveira

A Literatura para crianças e jovens no Brasil

de ontem e de hoje: caminhos de Ensino

Tese apresentada à Faculdade de Educação da Universidade de São Paulo para obtenção do título de Doutor.

Área de Concentração: Didática, Teorias de Ensino e Práticas Escolares

Aprovado em:

\section{Banca Examinadora}

Prof.Dr.

Instituição

Assinatura

Prof.Dr.

Instituição

Assinatura

Prof.Dr.

Instituição

Assinatura

Prof.Dr.

Instituição

Assinatura

Prof.Dr.

Instituição Assinatura 
Dedico

ao meu pai Joaquim e minha mãe Aparecida (in memorian) 


\section{AGRADECIMENTOS}

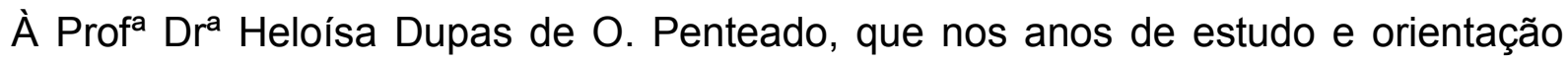
muito me ensinou com sua dedicação e paciência.

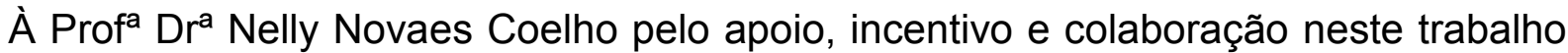
e pelo que ela representa para a Literatura Infantil brasileira.

À minha professora do curso primário, Dona Nelma, que me encantava com as histórias lidas ou contadas em sala de aula, tornando-as sementes fecundas dentro de $\operatorname{mim}$.

Às Irmãs de minha Congregação que me apoiaram, especialmente Irmã Maria Antonieta Bruscatto, que compreendeu a importância deste estudo.

À FEUSP pela qualidade do serviço prestado ao longo desse período de estudo, através da Coordenação, Professores e Secretaria. 
"Até quando as estratégias de formação de professores em serviço e as políticas públicas de acesso à língua escrita continuarão a desconsiderar o fato de que é preciso que os professores se tornem narradores, autores de suas práticas, leitores e escritores de suas histórias, para que possam ajudar as crianças a também se tornarem leitores e escritores reais, retirando prazer do falado e do lido e gostando de escrever?" Sonia Kramer 


\section{RESUMO}

OLIVEIRA, Maria Alexandre. A Literatura para crianças e jovens no Brasil de ontem e de hoje: caminhos de Ensino. 2007. 196 f. Tese (Doutorado) - Faculdade de Educação, Universidade de São Paulo, São Paulo, 2007.

Esta pesquisa visa contribuir com o ensino da Literatura Infantil em sala de aula no Ensino Fundamental I, considerando importante o papel do professor como mediador entre a criança e a obra literária. Com o objetivo de propiciar aos educadores um aprofundamento do conhecimento sobre a Literatura Infantil e do trabalho a ser realizado no contexto educacional de ensino, ressaltamos nessa literatura seu potencial formativo junto às crianças. Destacamos alguns possíveis critérios para escolha de obras infantis a serem trabalhadas em sala de aula que satisfaçam as exigências essenciais para serem consideradas Literatura para crianças e estejam adequadas aos propósitos de ensino e às possibilidades cognitivas dos alunos. Para tanto, selecionamos para análise 34 obras de 3 períodos distintos (Clássico, Tradicional e Contemporâneo), das quais 9 histórias foram tomadas para exploração das propriedades formativas do texto que apresentam nitidamente as características dos períodos em que se encontram. Consideramos importante apresentar, também, sugestões de propostas pedagógicas que abram caminhos aos docentes para viabilizar trabalhos que possibilitem a decodificação de metáforas contidas no texto e a transposição de seus significados para a vida e experiência dos alunos, impulsionando neles o imaginário e a criatividade. Para isso, precisamos nos debruçar sobre duas questões relevantes que, hoje, se colocam: a ausência da concepção de Literatura Infantil e da Literatura Infantil como campo de conhecimento nos documentos oficiais que orientam a Educação Brasileira.

Palavras chaves: Educação, Literatura Infantil, Ensino 


\begin{abstract}
OLIVEIRA, Maria Alexandre. The Literature for children and young peoples in Brazil past and present: ways of teaching. 2007. $196 \mathrm{f}$. Thesis (Doctoral) - Faculdade de Educação, Universidade de São Paulo, São Paulo, 2007.

The present research aims at contributing to the Children's Literature in Grade School, considering the teacher's important role as the mediator between the child and the literary work. With the purpose of helping educators to deepen their knowledge on Children's Literature and on the work to be accomplished in the teaching educational context, we emphasize literature's formative potential for children. We highlight some possible criteria for choosing children's books to be worked in the classroom that meet the essential demands in order to be considered Children's Literature and that are adequate for teaching purposes and for the students' cognitive possibilities. With that in mind, we have selected for analysis 34 works from three distinct periods (Classic, Traditional and Contemporary). Nine stories were taken to explore the text's formative attributes that clearly show the features of the periods they belong to. We also find it important to bring suggestions of pedagogical proposals that open paths for the teachers to produce works that enable the decoding of metaphors found in the text and the transposition of their meanings to the students' life and experience, stimulating imaginary thought and creativity in them. To do so, we must analyse two relevant matters today: the lack of a conception of Children's Literature and Children's Literature as a field of knowledge in the official documents guiding the Brazilian education.
\end{abstract}

Key words: Education, Children's Literature, Teaching. 


\section{SUMÁRIO}

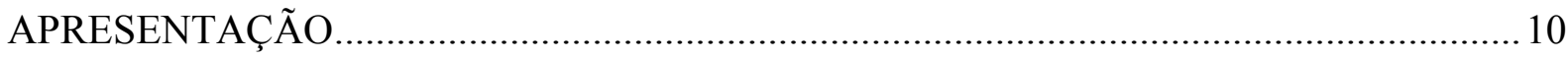

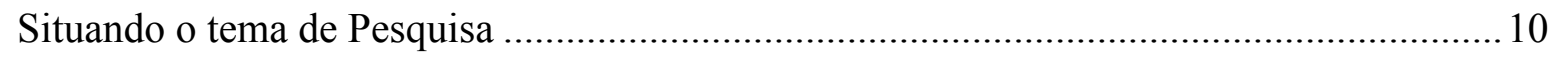

O Ensino atual da Literatura Infantil: constatações......................................................... 13

I - A Literatura Infantil, o ensino e formação de professores ................................................. 17

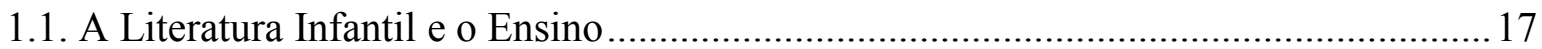

1.2 - Literatura Infantil e formação de Professores........................................................... 20

II - Breve esboço histórico da Literatura Infantil no Brasil ......................................................32

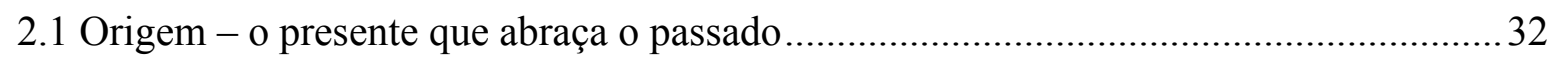

2.2 A Literatura Infantil no Brasil Colônia ............................................................................. 33

2.3 A Literatura Infantil no Brasil Reino - Dom João VI ................................................. 34

2.4 Literatura Infantil e política educacional no Brasil ....................................................... 37

2.5 A Literatura Infantil no Brasil Imperial de Dom Pedro II ........................................... 38

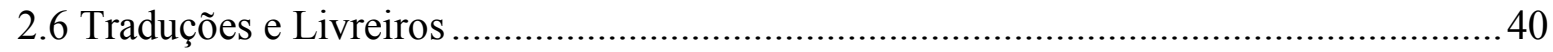

2.7 Precursores da Literatura Infantil Brasileira........................................................... 42

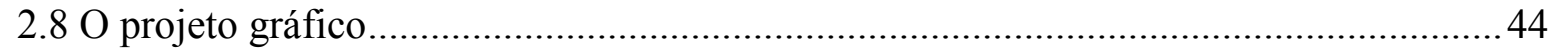

2.9 A presença da ilustração na Literatura Infantil.......................................................... 45

2.10 O papel da imprensa na Literatura Infantil Brasileira ..............................................51

2.11 Monteiro Lobato, o escritor da criança brasileira ...................................................52

2.11.1 A criação do Sítio do Pica-pau Amarelo - espaço do imaginário infantil .............55

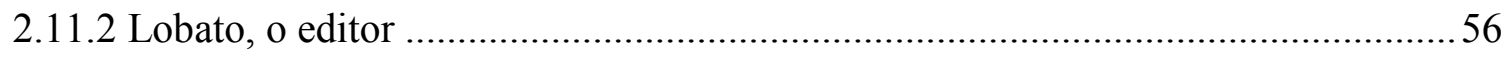

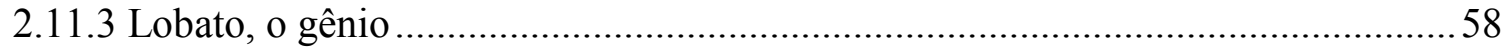

III - A Literatura Infantil caminhos da Educação e do ensino no Brasil ................................. 61

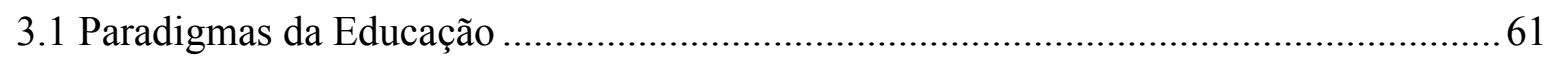

3.3 A defasagem entre a esfera literária e a educacional .................................................. 70

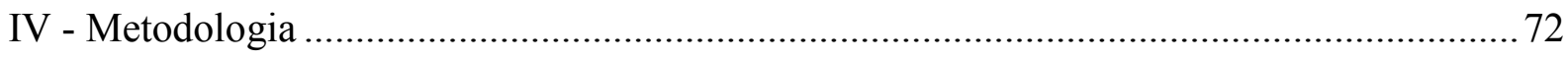

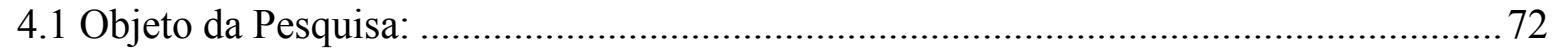

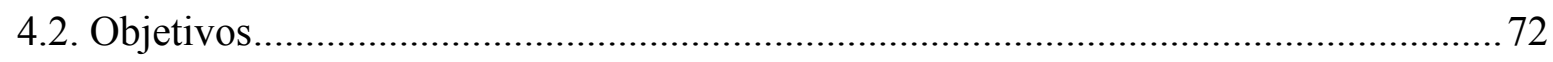

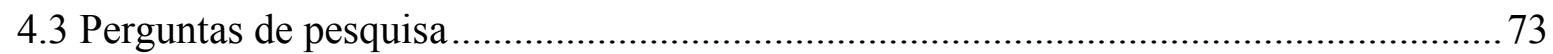




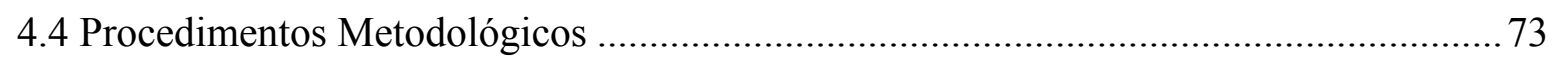

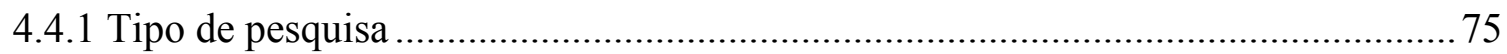

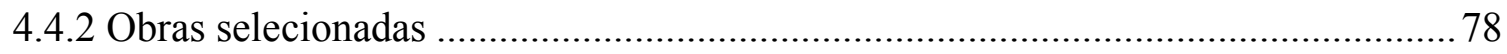

4.3. Classificação das obras selecionadas em períodos ....................................................... 81

$\mathrm{V}$ - Análise dos períodos da Literatura Infantil considerados e das obras selecionadas.......... 85

5.1. Caracterização geral dos três períodos da Literatura infantil ...................................... 85

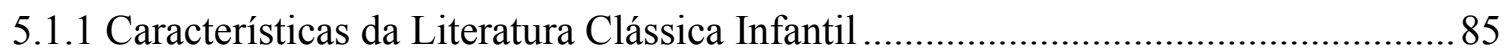

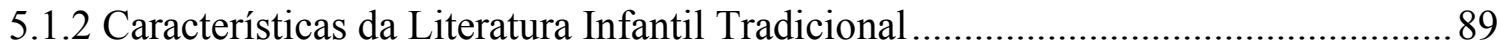

5.1.3 Características da Literatura Infantil Contemporânea ...........................................90

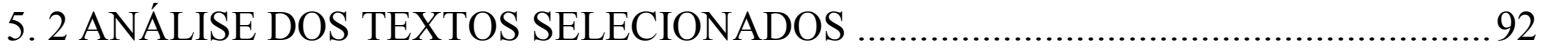

5.2.1Quadros demonstrativos de análise dos textos .................................................... 95

5.2.2. Complementando a caracterização dos períodos .................................................. 100

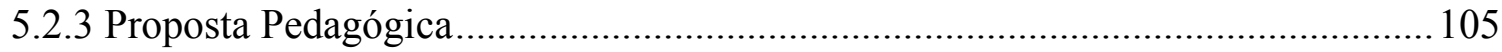

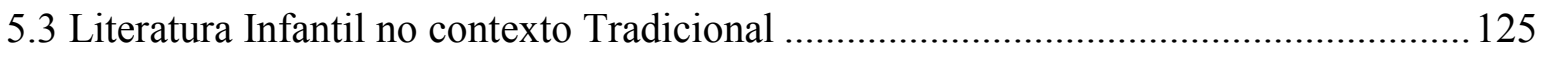

5.4 Literatura Infantil no contexto Contemporâneo ......................................................... 133

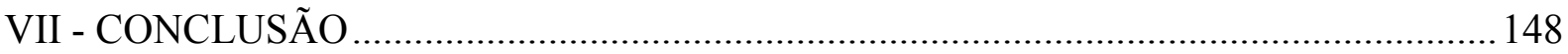

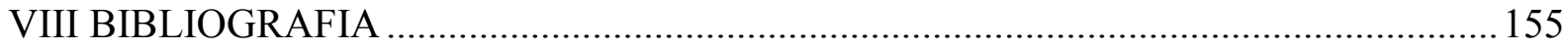

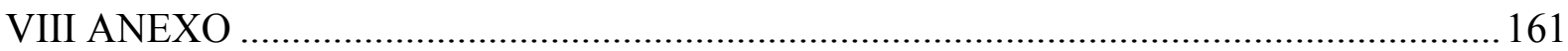

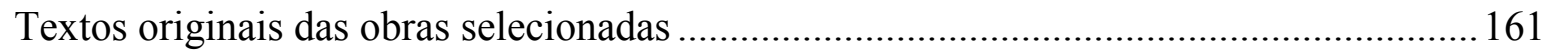

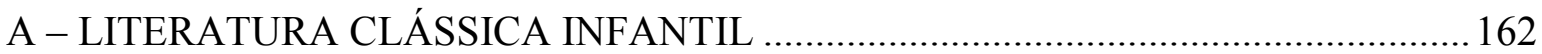

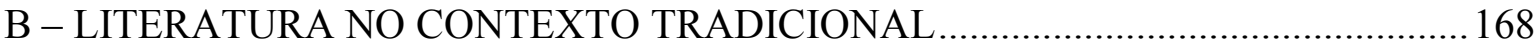

C - LITERATURA NO CONTEXTO CONTEMPORÂNEO …....................................... 178 


\section{APRESENTAÇÃO}

\section{SITUANDO O TEMA DE PESQUISA}

Inicialmente, nosso projeto de pesquisa voltava-se para a leitura da L.I. ${ }^{*}$ exercida pelo aluno e pelo professor, com o objetivo de verificar características de compreensão de um leitor e de outro. O que propiciaria ao professor confrontar sua leitura com a do aluno. Esse cruzamento de leituras possibilitaria elaboração de critérios de docência para crescimento tanto do professor quanto do aluno. O tema era $A$ mediação do professor na decodificação da leitura feita pelo aluno da Literatura Infantil.

A observação e coleta de dados se realizariam junto a alunos e professores do Ensino Fundamental I. Pretendia-se explicitar características da leitura da L.I. feita pelo adulto (professor) e pela criança (aluno) para ampliar a compreensão do papel mediador que o professor deve ter no ensino de L.I., de tal forma que possibilitasse aos alunos desenvolvimento pessoal e social.

No decorrer do processo de estudo para pesquisa, e em constante diálogo com a orientadora, foi se delineando uma outra proposta para levantamento de material a ser pesquisado, que nos pareceu anteceder a proposta anterior de pesquisa. Assim chegamos a um consenso: alterar os objetivos da proposta anterior de pesquisa.

Em continuidade à dissertação apresentada em nosso Mestrado no ano de 1995, com o título Leitura Prazer: interação participativa da criança com a Literatura Infantil na escola, nosso foco voltou-se para os livros de L.I. adequados ao Ensino Fundamental I.

\footnotetext{
* Sempre que nos referirmos à Literatura Infantil, usaremos a abreviatura L.I.
} 
Verificamos naquela ocasião que a seleção dos livros pelos professores se fazia de modo mais ou menos aleatório: ausência de critérios de escolha, que pudessem orientá-los em relação à qualidade literária do texto conjugado aos objetivos do ensino (a educação escolar é um ato intencional). Reorientamos então nosso trabalho.

Analisaremos livros de L.I. produzidos no Brasil ( ou de autores brasileiros ) desde as primeiras décadas do século XX até o início do século XXI. Devido à constante presença dos Contos Clássicos - maravilhosos e de fada no universo imaginário infantil - incluiremos, também, seis contos clássicos em nossa análise. Assim, nosso tema atual de pesquisa é: Literatura para crianças e jovens no Brasil de ontem e de hoje: caminhos de ensino.

Pelo fato da L.I. e Educação serem parceiras na formação do leitor, pretendemos verificar, nesse intervalo de tempo definido para a realização da pesquisa de doutorado, a intencionalidade dos textos em relação à criança, analisando os seguintes tópicos:

- se o texto contribui para o desenvolvimento do imaginário infantil propiciando novas descobertas;

- se propicia o desenvolvimento da fantasia e da criatividade infantil levando a possíveis desdobramentos da história;

- se apresenta conseqüências inibidoras a atitudes de coragem e ousadia;

- se se apresenta como instrumento de coerção, a partir de modelos de comportamento ideal, de obediência e submissão, herméticos a outras possibilidades.

Entendemos que o esclarecimento de tais tópicos permitirá estabelecer 
as concepções de "criança" que suportam cada obra, esclarecimento este que permitirá ao professor confrontá-las com a concepção que orienta sua docência junto aos alunos.

A partir de levantamento e análise do conteúdo dos textos literários produzidos no intervalo de tempo definido para essa pesquisa, pretendemos elaborar critérios que auxiliem o professor a proceder a escolhas menos aleatórias, mais conscientes de obras de qualidade literária e de valores veiculados pelos conteúdos. E que sejam condizentes com os propósitos requeridos por um ensino voltado para o exercício de uma vida saudável e de uma cidadania criativa, solidária, colaborativa, autônoma e ética. 


\title{
O ENSINO ATUAL DA LITERATURA INFANTIL: CONSTATAÇÕES
}

\author{
"E, por acreditar ainda na literatura como veículo essencial \\ para o desenvolvimento da imaginação criadora, bem como para a \\ perpetuação de valores fundamentais, tal preocupação, como não po- \\ deria deixar de ser, volta-se, \\ e de maneira incisiva, para o ensino literário". \\ Maria Thereza Rocco
}

A pesquisa de mestrado, realizada na FEUSP entre 1991 e 1994 com professores do Ensino Fundamental I, mostrou que o trabalho com a Literatura Infantil na escola era marcado muito mais pela expectativa de que os alunos memorizassem a história do que pela possibilidade de desenvolverem a compreensão do mundo através dela. Não se criava espaço para a exploração do imaginário e da fantasia em relação à obra lida, o que possibilitaria intensa troca didática entre os sujeitos da educação, alunos-professor. Praticamente isso não ocorreu ou ocorreu muito pouco. Houve pouca ou nenhuma oportunidade para deixar aflorar, fluir, brotar algo da espontaneidade da criança e da sua fantasia.

Constatou-se também o despreparo dos professores para o ensino de L.I. em sua formação inicial e continuada.

Ainda nessa pesquisa, uma experiência realizada com alunos do Ensino Fundamental I de uma Escola Estadual de Osasco, SP, que trabalha a L.I. desde a $1^{\text {a }}$ série, surpreendeu-nos sobremaneira a constatação da capacidade dos alunos da $2^{\mathrm{a}}$ série em estabelecerem com muito mais espontaneidade e rapidez a relação entre texto literário e contexto sócio-político-cultural, vivido por eles, do que fizeram os alunos da $3^{\mathrm{a}}$ e $4^{\mathrm{a}}$ séries ( e até mesmo os professores, que tiveram a mesma experiência nos cursos de formação continuada por mim ministrados.)

Dessas constatações surgiu uma indagação: por que a relação texto literário/contexto estabelecida pelas crianças diminui ou fica mais inibida à medida 
que avançam nas séries de escolaridade? A busca de resposta a essa questão apontou para a importância de se desenvolver um trabalho interativo com a L.I. em sala de aula. Ao promover o desdobramento da obra pela criança, o professor proporciona aos educandos condições para ampliar as possibilidades de comunicação do leitor não só com a obra, mas consigo mesmo e também com a vida, numa prática pedagógica que não se detém no ensino informativo do saber já produzido. Ao contrário, avança a partir desse saber rumo à construção de um saber novo que considera o saber da criança ${ }^{1}$ e propicia a sua re-elaboração.

Esse avanço exige que já a escolha da obra literária a ser trabalhada com os alunos seja orientada por critérios que explicitem para o professor o que ele pode desenvolver junto aos alunos no trabalho com o texto, definir-se por um texto adequado. Do ponto de vista aqui adotado, o trabalho com a L.I. não se esgota em mero exercício de leitura, de gramática, ou simplesmente em lazer. O seu ponto forte se traduz no fato de, através de uma atividade prazerosa a ser realizada com uma obra escrita especificamente para crianças, permitir explorar toda a propriedade formativa de que tal obra é portadora.

Para que isso ocorra é preciso que estejam claras para o professor as características compreendidas por uma obra literária infantil, dentre as quais destacamos:

- a concepção de infância que suporta a obra;

- $\quad$ tipo de linguagem escrita (formal, coloquial);

- tipo de discurso: autoritário, argumentativo, interativo;

- presença de ilustração adequada ao texto escrito;

- $\quad$ tempo histórico de sua produção;

- valores destacados;

\footnotetext{
${ }^{1}$ Quando falamos sobre o saber da criança, estamos considerando, aqui, o contexto cultural vivido por ela, isto é, as significações culturais experienciadas em seu cotidiano.
} 
- valores de uma educação conservadora;

- valores de uma educação emancipadora.

Esse avanço ocorre por meio de um exercício de problematização da obra que, na verdade, caracteriza uma prática pedagógica renovada com a L.I:

- possibilitando ao leitor, no nosso caso, o professor e os alunos, experiências, interações iniciais e individuais do leitor com a obra literária, mediante a exploração da história e a comunicação que se estabelece com as personagens;

- propiciando um processo de interação/participação entre os alunos e a história, de abertura para outras perspectivas educacionais de apreensão da mesma;

- dando oportunidade às crianças de descobrirem as múltiplas leituras que uma obra sempre admite.

Todavia o peso do modelo tradicional do ensino reprodutor na formação do professor é tão grande que, mesmo entre aqueles que através da formação continuada foram preparados para o ensino da L.I. (o que compreende o exercício da construção de sentido a partir da leitura e compreensão da obra), é possível que ocorra a mesma conduta reprodutora no ensino com as crianças, ainda que alterada qualitativamente. Ou seja, é possível que o professor agora oriente sua ação docente pela expectativa de reprodução de uma determinada decodificação da simbologia da história, aquela que ele, professor, conseguiu fazer. A participação dos professores nos cursos de formação continuada sobre o ensino de L.I., por mim ministrados, levou-os à descoberta de significados decorrentes dos exercícios de decodificação simbólica, a partir de seus pressupostos culturais, cujo entusiasmo sem precedentes - aliado 
ao papel reprodutor da cultura na construção das subjetividades - pode servir de suporte à hipótese da reprodução.

Foi diante desse problema educacional em aberto e dos resultados dessas primeiras pesquisas (animadoras, mas longe de serem suficientes) que, para a realização deste novo estudo visando ao doutorado, nos animamos a prosseguir nessa mesma linha de investigação, agora dirigindo nosso foco para a obra de LI. Seria contextualizando-a em seu momento de produção e de uso docente. 


\section{I - A LITERATURA INFANTIL, O ENSINO E FORMAÇÃO DE PRO- FESSORES}

\subsection{A LITERATURA INFANTIL E O ENSINO}

Um dos problemas, ainda em aberto neste início do século XXI, é a necessária articulação da Literatura (para crianças e adolescentes) com os projetos e métodos de ensino. Por que Literatura? Em que ela é importante para a formação das crianças e jovens, visando a adultos conscientes e atuantes? São interrogações necessárias e com respostas em constante elaboração.

Consultando a História, vemos que no âmbito do Ensino Fundamental, no Brasil, de alguma maneira, ainda que não trabalhada enquanto obra literária, a Literatura sempre esteve presente. No final do séc. XIX, com o processo de consolidação do sistema social consagrado pelo II Império (Dom Pedro II), a L.I. era considerada como caminho de transformação e, por isso foi inserida no contexto escolar. Vejamos o que dizem Zilberman e Lajolo ${ }^{2}$ a respeito:

[...] por causa da aliança entre literatura infantil e escola, foram os pedagogos os primeiros a se preocupar com o aparecimento e valor dos livros para crianças. Carlos Jansen, professor do Colégio D.Pedro II, foi tradutor e adaptador de histórias européias [...]. Na mesma época, José Veríssimo, crítico literário de renome, escreve A educação nacional, no qual reivindica livros brasileiros para crianças brasileiras.

E, ainda, podemos citar Leonardo Arroyo $^{3}$, no seu precioso trabalho Literatura Infantil Brasileira:

\footnotetext{
${ }^{2}$ ZILBERMAN, Regina \& LAJOLO, Marisa. Um Brasil para crianças - para conhecer a literatura infantil brasileira: histórias, autores e textos. São Paulo: Global Editora, 1988, pp.250251.

${ }^{3}$ ARROYO, Leonardo. Literatura Infantil Brasileira. São Paulo: Melhoramentos, 1988, p.172.
} 
[...] Devemos destacar desde logo a atuação de Carlos Jansen, a quem se deve a apresentação, em tradução brasileira, de muitas obras clássicas da literatura infantil, assim consideradas. Desde logo percebeu o ilustre professor do Colégio Pedro II as deficiências que havia no Brasil no terreno da literatura infantil e juvenil e as já manifestas inconveniências representadas pelas traduções ou originais portugueses. Carlos Jansen inscreve-se, desse modo, entre os pioneiros de nossa literatura infantil não só pelas traduções que realizou, como também pela consciência que tinha do problema.

Sendo a escola órgão-síntese dos valores da sociedade que a mantém, a Literatura oferecida às crianças, nessa época de consolidação do Sistema Social consagrado pelo II Império (Dom Pedro II) e prolongado pela República, servia para transmitir e preservar tais valores, ideais, normas de conduta, etc. O racional superou o literário e, no âmbito escolar, a Literatura servia principalmente para o estudo da língua, das normas gramaticais ou de simples instrumento moralista.

Todavia, a transformação cultural é um fato histórico. Esse fato nos permite recuperar a evidência, freqüentemente obscurecida por atuações culturais conservadoras e autoritárias, de que o homem é o autor da cultura e, como tal, é também o seu agente transformador. Tudo depende da qualidade das relações que com ela estabelece.

Isto nos alerta para a importância do papel da L.I. no ensino transformador e emancipador e do papel do professor, como mediador entre a criança e a literatura.

E para que a comunicação da criança com o enredo da história, sua relação com as personagens e situações focalizadas e a expressão de tais relações ocorram, é preciso que o professor proceda à escolha de obras condizentes com as necessidades de vida de seus alunos para que possam promover a interação participativa deles com a obra; crie espaços implementadores (não inibidores) das propriedades dessa leitura: provoque o desenvolvimento da fantasia, da imaginação, do brin- 
car; em síntese, crie o espaço da interação participativa* da criança com a história. É preciso propiciar a exploração da L.I. pela criança enquanto recurso emancipador que permite o estabelecimento de conexões de sentido com o que ela vive; o que permite a re-elaboração de medos, de fantasias, ampliando a elaboração pela criança de juízos de valor, a exposição a juízos diferentes, elaborados por diferentes leitores, o que conseqüentemente remete ao mundo da ética e sua construção. Isso será possível em uma pedagogia que contemple a cultura do aluno, usando métodos eficazes de ensino como afirma Saviani ${ }^{4}$ :

[...] serão métodos que estimularão a atividade e iniciativa dos alunos, sem abrir mão, porém, da iniciativa do professor; favorecerão o diálogo com a cultura acumulada historicamente; levarão em conta os interesses dos alunos, os ritmos de aprendizagem e o desenvolvimento psicológico, mas sem perder de vista a sistematização lógica dos conhecimentos, [...] dos conteúdos cognitivos.

\footnotetext{
* Denominamos "interação participativa" o desdobramento da história, junto à criança, quando: - possibilita ao professor e aos alunos conhecer as interações iniciais individuais do leitor com a obra através da exploração da história e a comunicação com os personagens;

- instaura um processo de participação ativa com a história entre os alunos; - é um processo enriquecedor e propiciador da abertura de outras perspectivas de apreensão da história;

-intensifica e potencializa o processo de interação inicialmente estabelecido entre o leitor e a obra.

${ }^{4}$ SAVIANI, Dermeval. Escola e Democracia. São Paulo: Cortez, 1983, p.79.
} 


\title{
1.2 - LITERATURA INFANTIL E FORMAÇÃO DE PROFESSORES
}

Para a concretização de tais propostas, faz-se necessário que o professor tenha uma formação sólida, consistente, reflexivo-crítica como nos apresenta Penteado: ${ }^{5}$

\begin{abstract}
É preciso atuar como um propiciador/agilizador da comunicação de saberes para que ocorra em fluxo contínuo entre as relações professor/aluno, aluno/aluno, resultando em reelaborações de qualidade. Qualidade esta a ser garantida pelo agir comunicacional e pelas ciências de referência das disciplinas escolares postas a serviço da compreensão de questões da realidade trazidas por professores e alunos e significativas para eles.
\end{abstract}

Será, portanto, com uma bagagem de formação que inclua a Pedagogia da Comunicação que o professor poderá contribuir para que a L.I., além de enriquecer o imaginário e a fantasia da criança, possa levá-la a se encantar e emocionar diante de uma história e possa se identificar, re-conhecer e enriquecer a realidade por ela vivida.

A prática docente que encaminha tal interação do aluno com a obra constituise simultaneamente em recurso que permite ao professor ampliar seu conhecimento sobre o universo de vida de seus alunos e os valores que por ele transitam.

Dessa forma, a Metodologia Comunicacional do ensino utilizada no trabalho com a L.I. permite que o professor esteja atento às possibilidades de cognição dos alunos, decorrentes de seu estágio de compreensão, e desenvolva estratégias que os levem a interagir com a leitura para:

\footnotetext{
${ }^{5}$ PENTEADO, Heloísa Dupas. Comunicação Escolar - uma metodologia de ensino. São Paulo: Editora Salesiana, 2002, p.34.
} 
- a construção de sentido da trama e compreensão do tema, através de um exercício de intracomunicação a partir do texto que resultará no discernimento dos valores aí encontrados;

- a contextualização dos valores do conteúdo da obra e de suas qualidades literárias que possibilitem uma escolha condizente com os propósitos de uma educação emancipadora, cidadã e democrática;

- um exercício de alteridade na intercomunicação que exponha a polissemia do texto, decorrente das diferentes decodificações possíveis, decorrentes das experiências de vida que referenciam a leitura de cada leitor, bem como das possibilidades de cognição decorrentes das diferentes faixas etárias dos leitores (bem distintas, no caso do professor e do aluno do Ensino Fundamental I). Em suma, com tal estratégia de leitura os alunos familiarizar-se-ão com as características da qualidade literária e dos valores humanos contidos no conteúdo da obra de L.I. nacional ou estrangeira. E o professor estará vivendo, deste modo, um processo de formação contínua, uma vez que alargará, a cada experiência de leitura, assim orientada, a compreensão do universo dos alunos, das potencialidade formativa das obras literárias e da articulação do trabalho com L.I. e os objetivos de sua docência.

Um dos objetivos desta nossa pesquisa é o de auxiliar o professor a descobrir a natureza específica do literário presente no livro a ser escolhido para o seu trabaIho docente, e a partir daí poder ter condições de atrair o aluno para a sua leitura e para as inúmeras descobertas, invenções, discussões, que a interação leitor/livro poderá provocar. É na escolha consciente das obras, a serem lidas pelos alunos, que começa o trabalho do professor. 
O discurso sobre a formação do educador é bastante contundente. A formação profissional, de maneira geral, está hoje sendo questionada: estará ela adequada à realidade de hoje? Estará ela buscando novos fundamentos epistemológicos? A indagação/reflexão sobre a prática ou ação docente inclui-se nos saberes do professor?

Entre avanços e recuos, o sistema educacional no Brasil está ainda buscando soluções para responder às necessidades formativas, exigidas pelo mundo atual, em acelerada mudança. Sob a influência dos multimeios de comunicação, impõe-se em nossos dias o sistema da Imagem e da Velocidade, que não abre espaço para a leitura e para a Literatura. Uma agravante expressiva desse fenômeno é a precária qualidade de formação dos professores, que, por sua vez, têm a seu cargo a formação de novas gerações. Tal lacuna pode ser minimizada com processos de "formação contínua", mas esses não são ainda suficientes, quer porque os órgãos governamentais da área educacional não investem de maneira adequada na importância do aprender contínuo, quer porque os empresários da escola nem sempre promovem o aperfeiçoamento e atualização do seu quadro docente. Ou ainda porque o próprio professor não cogita da necessidade de um aprimoramento contínuo, posto que em questão de ensinar, a formação está sempre inacabada, sempre em construção.

Um dos grandes meios para a necessária formação profissional do professor do Ensino Básico (e do aluno) é a L.I. que hoje vem ganhando espaço no cenário editorial. Faz-se urgente que ela seja divulgada, valorizada e explorada em seu potencial propiciador do crescimento intelectual, cultural e social dos leitores. 
neira subliminar, a fortalecer-se: pode sugerir e levá-la a abandonar sua condição de dependência infantil e ajudá-la a crescer com mais

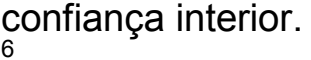

A L.I. é uma semente fecunda, carregada de vida, pronta para desabrochar na mente e nos corações dos leitores a esperança de um futuro mais humano. Como toda semente, necessita de cultivo. A mediação do educador, nesse processo de trabalho didático com decodificação da leitura feita pelo aluno, propiciará a este um novo olhar sobre a realidade, desvelando as múltiplas possibilidades que o cerca e o modo de lidar com essa realidade. Sensibilizados para o alcance do ensino da L.I. junto às crianças, os professores devem necessariamente desenvolver um processo formador e emancipatório que envolve:

- decodificação por parte deles, professores, do simbolismo e da fantasia contidas no texto de L.I. a serem trabalhados a partir da cultura docente;

- a compreensão de seu papel docente de mediador na relação da "cultura da criança com a obra literária", encaminhando o pequeno leitor para experiências de re-elaboração cultural, através do jogo, brincadeira, implementadores do sonho, do desejo, móveis da capacidade humana de criar cultura e desenvolver ações transformadoras.

Em outras palavras, esse processo envolve compreensão, por parte dos professores, do sentido emancipador da mediação didática que pode desenvolver a captação sensório/cognitiva do ser humano enquanto sujeito produtor/produto da cultura.

\footnotetext{
${ }^{6}$ CÂNDIDO, Amélia Fernandes. Literatura Infantil... mais além: a especificidade da literatura infantil como instrumento de estímulo ao desenvolvimento da linguagem. 2001.179 f. Dissertação (Mestrado em Estudos Comparados de Literaturas de Língua Portuguesa) Faculdade de Filosofia Letras e Ciências Humanas, Universidade de São Paulo, 2001, p.168.
} 
A L.I., explorada em suas propriedades formativas, constitui fértil possibilidade para esse intercâmbio. Enquanto produto cultural, ela interfere na cultura do aluno, reforçando-a, negando-a ou provocando-a, de diferentes formas, propiciando novos conhecimentos e uma re-elaboração de sua visão de mundo.

Corral ${ }^{7}$ afirma:

[...] a autêntica literatura infantil oferece, mediante um diálogo cultural específico, a abertura de uma nova forma de entender o universo e uma fértil multiplicação das experiências vitais, contribuindo, deste modo, para superar e complementar as limitações naturais, sobretudo na idade escolar.

É, portanto, fundamental que o professor esteja capacitado para usar as dinâmicas de leitura e levar o aluno para além da compreensão linear das histórias, a descobrir seus múltiplos significados. Sobre as múltiplas estratégias para vivificar a leitura da L.I. em sala de aula, nos detivemos detalhadamente no livro Dinâmicas em

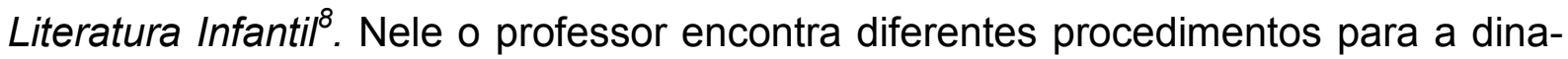
mização do trabalho com a L.I. em sala de aula.

Ao considerarmos o educando um sujeito concreto, inserido em um contexto sócio-político-econômico-cultural, mergulhado no mundo da tecnologia mediática da imagem, do som e da informática, não podemos deixar de pensar a educação, hoje, senão como um Processo de Comunicação que ${ }^{9}$

[...] considera o amplo e diversificado leque de linguagens presentes na sociedade atual, por meio das quais se abordam os objetivos do conhecimento e se realiza a comunicação humana, o que nos encaminha a lidar com a multiplicidade delas no ensino. E, além de refinar o uso da linguagem oral e escrita tradicionalmente presentes na escola, procura garantir dentro dela o uso de linguagens alternativas

\footnotetext{
${ }^{7}$ CORRAL, Luis Sánches. Literatura Infantil y lenguaje literario. Buenos Aires: Ediciones Piados Ibérica, 1995, p.161.

${ }^{8}$ OLIVEIRA,Maria Alexandre. Dinâmicas em Literatura Infantil. 12 ed. São Paulo:

Paulinas, 2006, pp.17-40.

9 PENTEADO. 2002, op. cit., p. 43.
} 
que se apresentam como recurso nas sociedades contemporâneas, entre elas a pictórica, a musical, a literária, a corporal etc.

Falar em educação, enquanto processo de comunicação, significa avançar em uma nova direção pedagógica. Se por um lado sentimos a urgência de organizar o ensino de maneira compatível com as novas exigências da sociedade, por outro lado, fortes marcas de formação tradicional e autoritária se impõem como resistência ao novo. Defrontamo-nos com um impasse a ser superado através do diálogo e do intercâmbio com a cultura e com o conhecimento dos sujeitos cognocentes, alunos e professores. A L.I. tem a força de romper com esse impasse, conforme Cândido ${ }^{10}$ :

\begin{abstract}
A literatura infantil estimula vários sentidos: seu estilo singular pode mostrar à criança uma nova gramática da comunicação sem regras muito fixas, unindo, dessa forma, o verbal, o imagético e o sensorial. $\mathrm{O}$ acesso a diferentes linguagens pode proporcionar um conhecimento da própria identidade. A consciência de nós mesmos depende não só da percepção das nossas sensações e da observação de nossas experiências pessoais, mas, principalmente, da percepção do outro.
\end{abstract}

É importante lembrar, como afirma Penteado ${ }^{11}$ :

[...] as novas tecnologias comunicacionais são apenas e tão somente prolongamentos refinados, recursos sofisticados, aptos a potencializar a capacidade comunicacional inerente ao ser humano, que o caracteriza como animal social por excelência e produtor de cultura.

Através da identificação do leitor com a obra e as trocas culturais em sala de aula, intensificadas pela mediação do professor, as visões de mundo do aluno defrontam-se com visões de mundo, da obra e de outras leituras de seus colegas. Não se detêm necessariamente em uma ou em outra, nem necessariamente se contra-

\footnotetext{
${ }^{10}$ CÂNDIDO, op. cit., p.170.

${ }^{11}$ PENTEADO, Heloísa Dupas (org. e aut.). Pedagogia da Comunicação teorias e práticas. São Paulo: Cortez, 1998, p.13.
} 
põem, mas propiciam o tecido de novas tramas, possíveis embriões de novas compreensões.

Penteado $^{12}$, ao tratar da Pedagogia da Comunicação, postula a aprendizagem como um fenômeno que:

Só acontece em um real processo de comunicação entre os interlocutores postos um em presença do outro; começa antes do encontro na escola e continua para muito além dela; tem na escola um tempo e um espaço para ser cuidada, fecundada, cultivada.

Compete à formação do educador capacita-lo para viabilizar, através da escola, esse processo de comunicação por meio de sua prática pedagógica, tendo presente o educando como um sujeito-em-formação, em processo de construção de sua identidade e do seu próprio conhecimento.

Esse processo de comunicação, segundo Penteado ${ }^{13}$, não é linear e ocorre no intercâmbio das culturas:

[...] interferências culturais, que ocorrem na intertextualidade, ou seja, no entrecruzamento de diferentes textos (o televisual, o literário, o cinematográfico, o radiofônico etc.), dentre os quais a própria leitura de realidade, ou meio ambiente, feita pelos agentes sociais, se constitui em um deles, uma vez que os processos comunicacionais não ocorrem no vácuo e muito menos incidem em sujeitos vazios.

Ao lidar com a L.I., em sala de aula, o professor pode propiciar a relação dialógica com o aluno e o aluno com sua cultura, com seus colegas, com sua realidade e consigo próprio, pois ao professor compete criar condições para que ele lide com a história a partir de seus pontos de vista, trocando impressões, brincando e jogando

12 PENTEADO, Heloísa Dupas. Televisão e Escola, conflito ou cooperação. São Paulo: Cortez, 1991, p.167.

${ }^{13}$ PENTEADO. 2002, op. cit., p.42. 
com ela, assumindo posições ante os fatos narrados, defendendo posições e personagens, criando novas situações pelas quais ele vai desdobrando a história original.

Uma história literária, por mais simples que pareça, traz em seu bojo um leque de possibilidades formativas para o processo de ensino-aprendizagem do educando. Entre essas possibilidades estão: as qualidades literárias do texto, os valores neles contidos, as situações focalizadas, as personagens descritas. Nas sociedades tecnológicas atuais, em que nos encontramos inseridos, há que se considerar a presença das mídias eletrônicas, também trabalhando valores de maneira sedutora, com linguagens que de alguma forma precisam ser incluídas no texto literário, enquanto mídia impressa, para que adquiram qualidades comunicacionais fortemente expressivas para crianças da sociedade atual, na qual muitas vezes se encontram entregues aos "cuidados da atraente babá eletrônica TV".

Na perspectiva da Pedagogia da Comunicação, Penteado ${ }^{14}$ afirma:

[...] será tão somente na vivência de uma didática que exercite a capacidade comunicacional humana e pratique a educação como um processo específico de comunicação que as tecnologias comunicacionais ganharão a possibilidade de exercer o seu poder transformador, rumo a uma educação escolar formadora, reveladora, suporte para o exercício pleno da verdadeira cidadania.

A envolvente presença da mídia eletrônica nas sociedades tecnológicas não pode ser ignorada na produção literária, enquanto mídia impressa, acrescentando às narrativas uma nova linguagem, que se verifica nas características imagéticas da produção gráfica. E, conseqüentemente, interferem na recepção dessa produção, que não pode ser ignorada na exploração da obra.

O livro é, também, uma mídia, produto de avanços da tecnologia que já vem dos tempos de Gutenberg.

${ }^{14}$ PENTEADO. 1998, op.cit., pp.13-15. 
A L.I. é, sobretudo, COMUNICAÇÃO, pois cria a relação entre sujeitos comunicantes: autor e leitor. As propriedades formativas e informativas da L.I. só se realizam e se concretizam na comunicação da criança com a história. Nesse sentido, é preciso considerar que na L.I. o mundo é reproduzido de forma simbólica, mediante a fantasia, o fantástico, o sonho, o mágico. Pelo rompimento das barreiras e limitações do real, cria as condições para que a criança, apesar de sua pouca idade, se defronte com questões complexas da realidade, tais como: egoísmo, fraternidade, competição, colaboração, fidelidade, falsidade, morte, desigualdades sociais, injustiças, guerras, violência, desemprego, direitos, e outras. E, por meio de uma linguagem acessível, com valores diversos, através do recurso da fantasia, é permitido à criança raciocinar no nível de suas possibilidades cognitivas, sobre situações da realidade complexa, de seu mundo e do mundo das coisas.

Zilberman ${ }^{15}$ falando da recepção da obra literária pelo leitor, afirma:

De um lado, situa-se o efeito, condicionado pela obra que transmite orientações prévias e, desse modo, imutáveis, porque o texto conserva-se o mesmo, ao leitor; de outro lado, a recepção, condicionada pelo leitor, que contribui com suas vivências pessoais e códigos coletivos, para dar vida à obra e dialogar com ela. Sobre essa base, de mão dupla, acontece a fusão de horizontes, equivalente à concretização do sentido.

Iser ${ }^{16}$, também nessa mesma direção, afirma: "O ato da recepção de um texto não se funda na identificação de duas experiências diferentes, uma nova e outra sedimentada, mas na interação destas duas; ou seja, na sua reorganização".

No contato da criança com a obra literária, estabelece-se uma dupla relação: do leitor com as personagens e das personagens com o leitor. Nessa comunicação, aquele se identifica ou não com as personagens ou com a situação vivida por elas.

\footnotetext{
${ }^{15}$ ZILBERMAN, Regina. Estética da Recepção e História da Literatura. São Paulo: Ática, 1989, p.65.

${ }^{16}$ ISER, Wolfgang. $\mathrm{O}$ ato da leitura, uma teoria do efeito estético. Trad. Johannes Kretschmer, São Paulo: Editora 34, 1999, p.52.
} 
Não é raro o leitor colocar-se no lugar da personagem, e essa experiência vivida por ele no campo subjetivo, levá-lo a uma comunicação com seu mundo interior, na busca da superação de seus conflitos e na elaboração de seu equilíbrio.

Bruno Bettelheim, ${ }^{17}$ educador e terapeuta infantil, dá força a nossa proposta de trabalhar a Literatura, em seu livro $A$ psicanálise dos contos de fadas. Como terapeuta, Bettelheim relata suas experiências e sua tarefa de encontrar alternativas e caminhos para ajudar crianças no seu desenvolvimento, a fim de capacitá-las a enfrentar seus conflitos, seus medos, suas angústias. Ele escreve:

[...] Fui confrontado com o problema de deduzir quais as experiências na vida infantil mais adequadas para promover sua capacidade de encontrar sentido na vida; dotar a vida, em geral, de mais significados. Com respeito a esta tarefa, nada é mais importante que o impacto dos pais e outros que cuidam da criança; em segundo lugar vem a nossa herança cultural, quando transmitida à criança da maneira correta. Quando as crianças são novas, é a literatura que canaliza melhor este tipo de informação.

Bettelheim, além de reconhecer a importância da Literatura no desenvolvimento da criança, não somente na expectativa de formar um leitor crítico, reflexivo, futuro cidadão em busca do seu espaço na sociedade, ele também reflete sobre como "lidar de maneira correta" com a L.I., e avança ${ }^{18}$ :

[...] A aquisição de habilidades, inclusive a de ler, fica destituída de valor quando o que se aprendeu a ler não acrescenta nada de importante à nossa vida. [...] A idéia de que aprendendo a ler, a pessoa, mais tarde, poderá enriquecer sua vida é vivenciada como uma promessa vazia quando as estórias que a criança escuta ou está lendo no momento são ocas. [...] Para que uma estória realmente prenda a atenção da criança deve entretê-la e despertar sua curiosidade. Mas para enriquecer sua vida, deve estimular-Ihe a imaginação: ajudá-la a desenvolver seu intelecto e a tornar claras suas emoções; estar harmonizada com suas ansiedades e aspirações; reconhecer plena-

\footnotetext{
${ }^{17}$ BETTELHEIM, Bruno. A psicanálise dos contos de fadas. 6.ed. Trad. Arlene Caetano. Rio de Janeiro: Paz e Terra, 1980, p.12.

${ }^{18}$ BETTELHEIM. op.cit., p.13.
} 
mente suas dificuldades e, ao mesmo, tempo, sugerir soluções para os problemas que a perturbam. Resumindo, deve de uma só vez relacionar-se com todos os aspectos de sua personalidade - e isso sem nunca menosprezar a criança, buscando dar inteiro crédito a seus predicamentos e, simultaneamente, promovendo a confiança nela mesma e no seu futuro.

Para que as possibilidades formativas da L.I. (adesão a alguns valores, resistências a outros, re-elaboração de alguns, disponibilidade para a ação) se desenvolvam ao máximo em sua potencialidade, é preciso oportunizar e intensificar as relações possíveis da L.I. com a vida da criança, através de brincadeiras e jogos com situações e personagens apresentadas no texto. A comunicação da criança com a história deve ocorrer de tal forma que aquela se envolva plenamente com esta, de modo a avançar para além da história e de modo que o professor possa conhecer a visão de mundo de cada aluno.

Essa intimidade da criança com a obra precisa ser proporcionada, captada pelo professor, para que as situações de ensino organizadas favoreçam o desenvolvimento das propriedades formativas do texto, apresentadas pelas múltiplas leituras de alunos e professores. Isto exige do trabalho docente:

- própria leitura do adulto;

- disponibilidade para propiciar e dinamizar a intimidade da criança com a obra, de modo que ela possa vivenciar a história a partir de seu contexto cultural de origem;

- habilidade para criar canais de comunicação ou troca com as crianças, por meio dos quais a leitura adulta de professor possa ser inserida como mais uma leitura entre tantas outras feitas pelas crianças.

Focalizamos até aqui uma dimensão da educação enquanto processo de comunicação: a comunicação interpessoal-presencial (professor/ aluno e alunos entre si), além da comunicação interpessoal à distância da criança com o autor. 
Todavia, para que o professor possa vivenciar essa "comunicação" é indispensável que ele tenha adquirido de antemão certos conhecimentos que (como dizia Paulo Freire) possam servir de leitura-de-mundo a "iluminar" as histórias, para além de seu conteúdo narrativo. Trata-se de conhecimentos que, no geral, são indispensáveis para o professor conhecer e sentir o significado maior da matéria literária com que está trabalhando.

Tais conhecimentos visam a situar o professor histórica e culturalmente no contexto brasileiro da L.I. Portanto, importante se faz que ele disponha de conhecimentos que lhe permitam responder às seguintes questões:

- Quando a L.I. começou a circular na sociedade brasileira?

- Qual a relação entre L.I. e escola?

- Quais as relações existentes entre os valores consagrados pela sociedade e a literatura para crianças?

- Quando e por quem foi criada a L.I. brasileira?

- Quais as características da L.I. que surgem no "boom" dos anos 1970?

- Como trabalhar didaticamente com a L.I., no sentido de formar a consciência de mundo dos novos, explorando o prazer da leitura?

Na história da L.I. no Brasil é que vamos encontrar subsídios para essas respostas. 


\section{II - BREVE ESBOÇO HISTÓRICO DA LITERATURA INFANTIL NO}

\section{BRASIL}

\subsection{ORIGEM - O PRESENTE QUE ABRAÇA O PASSADO}

A leitura não é prática neutra.

Ela é campo de disputa, é espaço de poder." Márcia Abreu

Qualquer que seja o espaço onde se pretenda rastrear a origem da L.I. seja de ordem geográfica (Ocidente-Oriente), seja cultural (africana-indígena-lusitana), seja ainda histórico (clássica, barroca, moderna) há um, "lugar" em que todas as divisões e ou subdivisões irão se encontrar: na oralidade. Para fundamentar essa premissa, citaremos três estudiosos com propriedade reconhecida. Comecemos por Paul Zumthor ${ }^{19}$ :

Admitir que um texto, num momento qualquer de sua existência, tenha sido oral é tomar consciência de um fato histórico que não se confunde com a situação de que subsiste a marca escrita, e que jamais aparecerá (no sentido próprio da extensão) 'a nossos olhos'. Então, trata-se para nós de tentar ver a outra face desse texto-espelho, de raspar, ao menos, um pouco o estanho. Lá atrás, além das evidências de nosso presente e da racionalidade de nossos métodos, há este resíduo: o múltiplo sem origem unificadora nem fim totalizante, a 'discórdia' de que fala Michel Serres e cujo conhecimento pertence ao ouvido.

Fryda Mantovani ${ }^{20}$ escreveu:

El libro para niños es conquista moderna. No asi la literatura infantil, cuya origen se remonta a la edad oral del mito: nodrizas, rapsodas y pedagogos transmitian de viva voz a la infância, primero em Grécia y luego em Roma, las tradiciones de sus antepasados, fabulas, leyendas heróicas y religiosas y aventuras extraordinárias; triunfaba el arte

\footnotetext{
${ }^{19}$ ZUMTHOR, Paul. A letra e a voz: a Literatura Medieval. Trad. Amalio Pinheiro e Jerusa Pires Ferreira, São Paulo: Companhia das Letras, 2001, p.35.

${ }^{20}$ MANTOVANI, Fryda. Sobre las hadas. Buenos Aires: Editorial Nova, 1959, p. 22.
} 
de contar y la discipliba de escuchar, dice Battistelli, tratadista italiana de este tema.

Ecléa Bosi ${ }^{21}$ defende: "Sempre houve dois tipos de narrador: o que vem de fora e narra suas viagens; e o que ficou e conhece sua terra, seus conterrâneos, cujo passado o habita. [...] A arte da narração não está confinada nos livros, seu veio épico é oral”.

Valendo-nos dessas citações, pontuaremos a origem da L.I. Brasileira na história com a miscigenação das três etnias que, originalmente, formaram o povo brasileiro: a indígena, a européia e a negra. Autênticas fontes da literatura oral, esses contadores de histórias assentaram as primeiras pedras para construir a "Casa da Memória" de um povo que nascia... memória oral construída na mistura de três povos, três culturas... Literatura perpetuada e recitada ainda no tempo presente, que descobre e redescobre os valores das tradições que continuam escrevendo as estórias para nossas crianças e que sempre estarão por terminar.

\title{
2.2 A LITERATURA INFANTIL NO BRASIL COLÔNIA
}

\author{
"Hay más de um modo de \\ cometer infanticidios, y uno \\ de ellos es asesinar a la infância \\ sin asesinar al infante." \\ Chesterton
}

Ainda que muitos estudiosos e pesquisadores na área de História, leitura e L.I. no Brasil não encontrem documentos que atestem a existência de uma literatura escrita voltada para crianças nas primeiras décadas do Brasil-Colônia, não podemos deixar no esquecimento o acervo de contos orais populares, que nos foram trazidos pelos primeiros colonizadores e que deviam alimentar a imaginação dos primeiros habitantes do Brasil. Se não há registro histórico da entrada dessa Literatura popular

${ }^{21} \mathrm{BOSI}$, Ecléa. Memória e Sociedade: lembranças de velhos. 2.ed. São Paulo: EDUSP, 1987, p.43. 
em nossa terra, temos o testemunho da tradição: no Nordeste, por onde entraram grandes levas de colonizadores e de escravos, as histórias infantis que correm de boca em boca, até os nossos dias, são chamadas de Histórias de $\operatorname{Trancoso}^{22}$. O que indica que para cá foram trazidas as Histórias de Proveito e Exemplos, do autor português Gonçalo Fernandes Trancoso, publicadas em 1575 e, provavelmente, nessa época trazidas para cá, pois faziam grande sucesso no meio popular português. A tal ponto chegou esse sucesso que o nome do autor passou a caracterizar um gênero narrativo popular: Histórias do Trancoso, que divertem crianças e adultos.

Naquele tempo recuado do Brasil Colônia, quando o principal era a luta pela sobrevivência no enfrentamento com a natureza livre, podemos imaginar que, nos momentos de descanso, histórias fossem contadas, como, talvez, as dos indígenas, negros e portugueses.

\subsection{A LITERATURA INFANTIL NO BRASIL REINO - DOM JOÃO VI}

Ameaçado pela França bonapartista e refém economicamente da Inglaterra, D. João VI abandonou Lisboa, até então, capital durante sete séculos de Portugal — e transferiu a Corte para o Rio de Janeiro. D. João VI e sua corte (cerca de 15.000 pessoas) aportaram no dia 07 de março de 1808 em meio a grandes festas. Reinado em decadência, Portugal ainda mantinha o pé fincado em quatro continentes: (Angola - África; Macau-Ásia; Brasil-América; Portugal-Europa). Para o Brasil, até então colônia, sediar a capital do Império significava muito. Entre vantagens e problemas, a presença da Corte portuguesa no Brasil trouxe mais vantagens do que prejuízos,

${ }^{22}$ Conforme apostila da Prof. Nelly Novaes Coelho, 1999. 
principalmente, na cultura e educação. Valemo-nos de um relato de Caldeira ${ }^{23}$, para desenhar o cenário de um povo, que até então, não era admitido na Europa:

Numa colônia isolada como o Brasil, esse contato foi um enorme avanço. Senhores dos conhecimentos da terra, graças aos casamentos com as índias, aos brasileiros faltava a noção de que poderiam se governar - até porque ocultar isso fora uma deliberada política portuguesa. A falta de escolas, livros, tipografia era fruto de um grande planejamento, que agora se dissolvia.

A abertura dos portos brasileiros às nações amigas de Portugal (leia-se Inglaterra), a criação do Jardim Botânico, autorização para a abertura de uma faculdade, surgimento de teatros, escolas de música, liceus, colégios faziam pairar sobre aquela antiga aldeia colonial novos ares. Abria-se um novo horizonte que deixaria um marco importante na história do ensino. Vale citar Arroyo ${ }^{24}$

É do período de D. João VI no Brasil uma formulação inteiramente nova sobre a necessidade de ensino no país. É ela lembrada por Helio Vianna quando recorda que D. João VI 'por si' ou por seus ministros, cuidou atentamente da instrução pública em seus primeiros graus. Para tanto permitiu a qualquer pessoa a abertura de escolas de primeiras letras, independente de exame de licença, isto depois de ter ele mesmo ordenado a criação de muitas escolas dessas por todo o Brasil.

E Caldeira ${ }^{25}$ completa com a seguinte observação:

A abertura para o mundo completou-se com a presença de um tipo até então proibido de entrar no país: o estrangeiro. Em três séculos, a colônia tropical da América ganhara uma imagem de exotismo na Europa - que passaria afinal pelo crivo da experiência direta. Começava a leva de livros feitos a partir de viagens pelo país, onde o fascínio se misturava com horror. Fascínio pela natureza, pela vegetação. E horror por tudo que viam como diferente: ruas acanhadas, alimentação estranha, informalidade, proximidade dos escravos, negação do valor do trabalho, sexo. Os relatos misturavam preconceito

${ }^{23}$ CALDEIRA, Jorge et al. Viagem pela História do Brasil. São Paulo: Companhia das Letras, 1997, p.124.

${ }^{24}$ ARROYO, op. cit., p. 66.

${ }^{25}$ CALDEIRA, op. cit., p. 128. 
e realidade, mas os brasileiros não tinham como se defender. Nascia a condenação aos hábitos formados em contato com a realidade tropical.

Contudo, mesmo nesse novo cenário, a L.I. - autêntica, genuína, da cor da terra, com cheiro das matas e sabor de fruta tropical, ao gosto da criança brasileira ainda esperaria mais de um século para florescer e criar a sua própria história.

Com as medidas sociais e políticas tomadas com a chegada de Dom João VI e a Família Real Portuguesa ao Brasil, vislumbrava-se um novo cenário para a educação e cultura naquela colônia estagnada que era o Brasil.

Mesmo considerando que todas as medidas tomadas pelo príncipe regente atendiam tão somente aos seus interesses e de sua Corte, aquele momento histórico significou um passo marcante não só para a história da L.I. Brasileira, como também para outras histórias, uma vez que o Brasil se tornaria brevemente nação independente. Foi o começo de uma radical mudança cultural. Os historiadores divergem desse acontecimento político. Entre os que discutem o seu alcance está Nelson Werneck Sodré26:

A abertura dos portos, a liberdade comercial, a franquia tarifária, proporcionaram sem dúvida alguma, um desenvolvimento e uma difusão maior na atividade comercial. Isso influiu para acelerar a urbanização. [...] O que não aconteceu, nem podia acontecer, foi a radical mudança que, alguns intérpretes superficiais supõem. Não existiu nenhuma alteração na posição relativa das classes; nem mesmo o instituto servil ficaria abalado, pelo menos na aparência.

"O que não aconteceu”, segundo o historiador, também se refletiu na Educação no Brasil e na L.I.

\footnotetext{
${ }^{26}$ SODRÉ, Nélson Werneck. História da Literatura Brasileira. 3.ed. Rio de Janeiro: José Olympio,1960, p.165. Apud ARROYO, Leonardo. Literatura Infantil Brasileira. São Paulo: Melhoramentos,1988, p.72.
} 


\subsection{LITERATURA INFANTIL E POLÍTICA EDUCACIONAL NO BRASIL}

Desde os tempos coloniais até as duas primeiras décadas do século $X X$, a educação no Brasil não foi prioridade na pauta política dos governantes. Algumas vezes fora tema de debate, mas sob o ponto de vista prático, pouco ou quase nada foi feito no Império e nos primeiros governos republicanos para que a educação fosse considerada como agente de transformação na construção de uma sociedade, cuja égide fosse resguardar o direito de acesso à escola. Já dizia Monteiro Lobato: "Um país se faz com homens e livros". Adiante discorreremos sobre a importância desse visionário no cenário da L.I. no Brasil. O que fica registrado é que a L.I. para construir a sua história fez parte de um amálgama com o ensino, pois a falta de uma política educacional priorizando a abertura de escolas e o acesso aos bancos escolares impediram uma formação de leitores - crianças e jovens - que demandassem livros infantis para o desabrochar dessa literatura. Assim escreve Arroyo ${ }^{27}$ :

Nem sempre será possível estabelecer-se uma separação nítida entre os livros de entretenimento puro e o de leitura para aquisição de conhecimento e estudos nas escolas, durante o século passado (no caso, século $X I X)^{28}$. Percebe-se que a literatura infantil propriamente dita partiu do livro escolar, do livro útil e funcional, de objetivo eminentemente didático.

Além disso, mesmo depois de proclamada a Independência e até meados da República Velha, os livros estrangeiros - quer na língua de origem do autor, quer traduzidos para português de Portugal - eram largamente usados para aqueles poucos privilegiados da elite, que tinham acesso à educação escolar. E assim, também, tais livros eram mais comercializados.

Desse modo, a existência da "Literatura Infantil" só se justificava para fins didáticos.

\footnotetext{
${ }^{27}$ ARROYO, op. cit., pp.93-94.

${ }^{28}$ Observação nossa.
} 


\subsection{A LITERATURA INFANTIL NO BRASIL IMPERIAL DE DOM PEDRO II}

Um século depois de Charles Perrault ter resgatado, na França, os contos populares franceses, que se tornaram contos infantis famosos; os irmãos Grimm, na Alemanha do século XIX, seguindo o interesse dos "altos estudos" (filologia, arqueologia, mitologia) pelo passado arcaico, terem resgatado centenas de contos populares que hoje fazem parte da Literatura Infantil Clássica; foi que esses contos infantis, juntamente com fábulas, contos exemplares e cartilhas, começaram a ser difundidos no Brasil, via Portugal ou França, ligados à preocupação oficial com a educação e com o ensino, durante o governo imperial de Dom Pedro II.

Pouco antes, na Europa, começaram a difusão dos ideais liberais românticos (de valorização do Indivíduo para além de sua classe social) e a emergência da família burguesa, com a valorização da cultura para formação dos pequenos. A educação escolar ganhou maiores espaços, acolhendo crianças, até então, consideradas "incapazes" de aprendizagem antes de completados os 9-10 anos. Abriram-se escolas para o ensino obrigatório. Phillipe Ariès ${ }^{29}$ registra essa nova visão:

A regularização do ciclo anual das promoções, o hábito de impor a todos os alunos a série completa de classes, em lugar de limitá-la a alguns apenas, e as necessidades de uma pedagogia nova, adaptada a classes menos numerosas e mais homogêneas, resultaram, no início do século XIX, na fixação de uma correspondência cada vez mais rigorosa entre a idade e a classe. Os mestres se habituaram então a compor suas classes em função da idade dos alunos.

\footnotetext{
${ }^{29}$ ARIĖS, Philippe. História Social da criança e da família. 2.ed. Trad. Dora Flaksman, Rio de Janeiro: Editora Guanabara, 1981, p.177.
} 
Nesse novo contexto social e familiar é que surge, entre outros campos epistemológicos, a L.I. As histórias eram elaboradas para se converterem em instrumen-

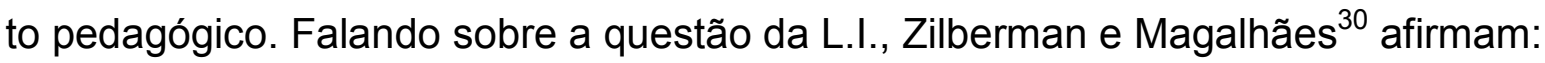

Assim, a emergência deste gênero explica-se historicamente, na medida em que aconteceu estreitamente ligada a um contexto social delimitado pela presença da família nuclear doméstica e particularização da condição pueril enquanto faixa etária e estado existencial. Por outro lado, tornou-se um dos instrumentos através do qual a pedagogia almejou atingir seus objetivos.

Esse objetivo, mencionado pelas autoras, se traduz na L.I pela absorção e disseminação de normas de boa conduta, de bom comportamento. No contexto em que a L.I. surgiu, sobretudo no Brasil em fins do século XIX e início do século XX, os valores sociais, também, estavam voltados para questões de comportamento, pois era o momento de consolidação do sistema social. Daí ser a L.I. considerada um excelente meio para induzir o leitor à obediência das normas consagradas. Hoje, tal sistema está superado e é bastante criticado, conforme Zilberman e Lajolo ${ }^{31}$ : "A falta de qualidade artística e o excesso de intenções moralizantes vêm juntos e, aliados, contribuem para o descrédito da literatura nacional para a infância e para a atrofia do gosto de ler".

A pesquisa realizada por vários autores - Nelly Novaes Coelho (1991), Regina Zilberman (1987), Ligia Cademartori Magalhães (1987), Marisa Lajolo (1985), Laura Sandroni (1987), Eliana Yunes (1988), Bárbara Vasconcelos (1985) - com obras de L.I., publicadas a partir das primeiras décadas do século XX até aproximadamente os anos 70 no Brasil, demonstrou essa tendência.

${ }^{30}$ ZILBERMAN, Regina \& MAGALHÃES, Ligia Cademartori. Literatura Infantil: autoritarismo e emancipação. São Paulo: Ática, 1987, pp.11-12.

${ }^{31}$ ZILBERMAN, op. cit., p.255. 
Enquanto colônia ou mesmo pós-independência, a L.I. que chegou ao Brasil via Metrópole, ou seja, com influências européias através de Portugal, seguia o modelo dos livros lançados em outros países da Europa. Conselhos e Avisos de uma mãe a seus filhos, de Maria da Trindade de Portugal Malheiro e Melo Baiana, segue de perto o livro da Marquesa de Lambert, inclusive com o mesmo título. Os Dous Robinsons, lançado em Lisboa em 1832 de autoria ignorada, é uma clara adaptação do best seller inglês Robinson Crusoe, de Daniel Defoe. Além disso, havia a forte influência, não só no campo cultural, dos intelectuais portugueses que mantinham contatos muito próximos com os outros países. Referindo-se à influência européia na L.I., através de Portugal, Leonardo Arroyo ${ }^{32}$ diz: "Tais leituras eram quase sempre pesadas, de um espírito moralista acentuado na sua falsidade ou precariedade, obrigacionais, sem o menor interesse pelo entretenimento, como o compreendemos hoje". Será contra essa Literatura desgastada e estéril que Monteiro Lobato se voltará no início do século XX.

\subsection{TRADUÇÕES E LIVREIROS}

Segundo Arroyo, os grandes clássicos da L.I. universal constituem o alicerce da formação da história da L.I. no Brasil. Foram eles que, traduzidos ou não, caíram nas mãos das crianças brasileiras e alimentaram sua imaginação. Para muitas delas foram fontes de inspiração declaradas, quando já adultos, deram depoimentos dos momentos prazerosos que tais livros proporcionaram na infância.

Fábulas, de Fedro; Fábulas, de La Fontaine; Os contos da Mamãe Ganso, de Perrault; Robinson Crusoe, de Daniel Defoe; As Viagens de Gulliver, de Swift; as coletâneas dos irmãos Grimm; Aventuras de Pinóquio, de Collodi; Contos, de Ander-

\footnotetext{
${ }^{32}$ ARROYO, op.cit., p.83.
} 
sen; A ilha do Tesouro, de Stevenson; obras de Júlio Verne circulavam no Brasil, trazidos pelas primeiras livrarias. As primeiras obras que chegaram eram traduções feitas em Portugal; depois começaram traduções feitas no Brasil, sendo que, muitas vezes, ambas eram comercializadas simultaneamente.

Ainda Arroyo ${ }^{33}$ aponta "como das mais antigas traduções aparecidas em português, como obra endereçada à infância e adolescência, o Robinson Crusoe, de Daniel Defoe", na tradução de Henrique Leitão Sousa Mascarenhas, em 1786, em Lisboa.

Os editores Garnier, Laemmert e Quaresma foram os pioneiros na comercialização de livros no Brasil, no séc.XIX e começo do séc.XX, sendo que mais popular era a Livraria Quaresma, porque seu velho proprietário, Senhor Quaresma, mantinha-se atento à demanda do público; era quem mais estabelecia contato com o leitor brasileiro. Foi daí que nasceu sua idéia de "abrasileirar o comércio de livros", nas palavras do cronista Luis Edmundo. Sabemos disso, porque Arroyo ${ }^{34}$ escreveu:

Luis Edmundo salienta que a literatura infantil vinha toda ela de Portugal redigida numa linguagem já caracteristicamente diferenciada em relação ao Brasil, 'tanto que as nossas crianças não entendiam a maioria dos textos desses mesmos livros'. Esta observação revela que o português, já então influenciado no Brasil pelos negros e índios, imbuía-se do espírito tropical da terra, que o amolecia, tornava mais doce e mais plástico.

A citação do cronista Luis Edmundo, apud Leonardo Arroyo, leva-nos a observar que uma das bases na formação da história da L.I. no Brasil foi a L.I. estrangeira. Contudo, na mesma citação, já se sentia um "sopro de nacionalismo", pois se questionava a legitimidade das traduções para as crianças brasileiras. Lobato, antes mesmo de publicar livros infantis, considerava as traduções dos livros correntes no

\footnotetext{
${ }^{33}$ ARROYO, op. cit., p.99.
}

${ }^{34}$ ARROYO,op. cit., p.110. 
Brasil como se estivessem em "grego". Jorge Rizzini ${ }^{35}$ foi quem registrou o comentário de Lobato:

\begin{abstract}
Esses livros eram traduzidos para as crianças portuguesas, que provavelmente não entendiam nada, também. E eram mal impressos, com ilustrações piores que o nariz do ilustrador. Também eu, quando criança, detestava tais livros 'miríficos', que quer dizer 'maravilhosos, admiráveis'. E como não entendia patavina do que estava escrito neles, divertia-me 'lendo' as figuras. Pobres crianças daquele tempo! Nada tinham para ler. E para as crianças, um livro é todo um mundo.
\end{abstract}

\title{
2.7 PRECURSORES DA LITERATURA INFANTIL BRASILEIRA
}

Foi através do Senhor Quaresma que veio a iniciativa de se construir uma biblioteca endereçada às crianças brasileiras. Amigo do jornalista Figueiredo Pimentel, o velho Quaresma encomendou-Ihe livros que confluíssem com o seu sonho de "abrasileirar os livros infantis". Assim, Figueiredo Pimentel, cronologicamente, inicia uma etapa histórica na formação da L.I. brasileira. O escritor publicou em 1896 Os Contos da Carochinha, em 1894; Contos de Fadas, (tradução de Perrault, Grimm e outros); Histórias da Avozinha e Histórias da Baratinha. Seriam ao todo dez títulos, publicações de grande êxito, cuja importância entraria na história da L.I. pelo seu intento revolucionário. Figueiredo Pimentel norteava suas estórias pelo viés do popular. Seus livros não estavam comprometidos com a metodologia educacional, ou seja, não eram feitos para os bancos escolares e sim, dedicados à infância brasileira "[...] vinham preencher sensível lacura, (sic); neles estão reunidos muitíssimos contos populares, que andavam espalhados exclusivamente na tradição oral, passando de geração em geração, sem no entanto nunca haverem sido colecionados e escritos". ${ }^{36}$

\footnotetext{
${ }^{35}$ RIZZINI, Jorge. il. Messias. Vida de Monteiro Lobato (Para a Infância e Juventude). 2.ed. São Paulo: Difusora Cultural, 1966, p.151.

${ }^{36}$ PIMENTEL, Figueiredo. il. Julião Machado. Histórias da Avozinha: livro para crianças.

São Paulo: Livraria Quaresma, 1959, p.9.
} 
A professora Alexina de Magalhães Pinto, escritora e pesquisadora mineira, também, escreveu livros que visavam ao público infantil. Em 1909, publicou seu primeiro livro Os Nossos Brinquedos, cujo enredo valorizava temas populares, especificamente voltados para crianças. Ela reunia em seus livros cantigas de roda, provérbios, poesias, jogos, cirandas, parlendas, adivinhas, brincadeiras, recolhas do folclore brasileiro. A professora fazia um inventário da memória popular e registrava-o na escrita. A importância dessa escritora, dentre os precursores da L.I. no Brasil, está nesse espírito que valorizava a terra e sua história, construída na memória daqueles que efetivamente formaram o povo brasileiro. Seus livros para o público infantil tinham a preocupação "de reintegrá-lo na verdade da terra e sua cultura oriunda da confraternização do português com o índio e com o negro". ${ }^{37}$ Além disso, Alexina de MagaIhães Pinto se destacou por levantar bibliografias que atendiam setores educacionais precários àquela época. Em seus livros, indicava obras estrangeiras que ela considerava apropriadas à educação de sua época. Sabia da falta de literatura que conquistasse os pequenos leitores: livros ilustrados, recreativos, que despertassem nas crianças o prazer de ler. Arroyo ${ }^{38}$ assim escreve:

Talvez se pudesse destacar mais ainda a importância de Alexina de Magalhães Pinto no contexto histórico da literatura infantil brasileira, ao lembrarmos que foi ela a primeira autora a indicar uma Biblioteca para a Infância no Brasil, ou seja, a relação de livros mínimos que se deveria dar aos meninos para lerem. Já no Brasil se começava a libertar a infância do livro escolar propriamente dito, procurando dar-lhe uma literatura adequada à idade. Alexina de Magalhães Pinto representa no Brasil um dos pontos altos dessa reação à literatura escolar e aos velhos conceitos sobre a infância.

\footnotetext{
${ }^{37}$ ARROYO, op. cit., p.178.

${ }^{38}$ Ibid., p. 182.
} 


\subsection{O PROJETO GRÁFICO}

Em 1915, as Edições Melhoramentos lançam a história O Patinho Feio, o primeiro livro de uma série de 100 títulos que formariam a Biblioteca Infantil. A coleção era dirigida por Arnaldo de Oliveira Barreto, cujo mérito foi o modo sistemático e organizado de conduzir a coleção, tornando-a a mais extensa e a mais popular do Brasil. A Livraria Quaresma, sem desprezar sua iniciativa histórica, não conseguiu levar adiante sua coleção iniciada por Figueiredo Pimentel. O que revolucionava a coleção das Edições Melhoramentos não era o seu conteúdo, mas o formato dos livros. Recorremos a Arroyo ${ }^{39}$ :

[...] Os livros da série inovavam a leitura para a infância pelo seu aspecto gráfico. Fisicamente já representavam um divórcio dos moldes escolares. Não eram volumes pesados, com aquela seriedade doutoral dos lançamentos do século XIX. Pelo contrário, desde seu aspecto externo eram uma festa para os olhos dos meninos pelo seu colorido e a figura simpática da vovozinha cercada de netos. Eram volumes de poucas páginas entremeadas de gravuras também coloridas, estórias compostas em tipo grande, com um equilíbrio de texto em cada página que constituía em verdadeira atração para a leitura.

Enfim, nesse esforço, ainda inacabado, em identificar acontecimentos e publicações que traçaram as preliminares da L.I. no Brasil, através das pesquisas realizadas, ressaltamos que o livro de Leonardo Arroyo, Literatura Infantil Brasileira, foi e ainda será o maior suporte dessa linha histórica. Dentre os títulos que se destacaram nesses primórdios da LI brasileira, registramos:

- Através do Brasil, de Manuel Bonfim e Olavo Bilac, editado no Brasil pela Livraria Francisco Alves ${ }^{*}$ cujo valor enquanto L.I. para a criança brasileira, ainda que voltada para o estudo escolar, tinha o mérito de

\footnotetext{
${ }^{39}$ ARROYO, op.cit., pp.186-187.

* A $1^{\text {a }}$ edição foi feita em Paris, no ano de 1910, conforme José Veríssimo, em seu livro A Educação Nacional. Apud, ARROYO, Leonardo. A Literatura Infantil Brasileira. São Paulo: Melhoramentos, 1990, p.190.
} 
apresentar a geografia do Brasil e sua exuberante natureza, através da narrativa nacionalista e poética dos autores;

- Saudades, de Tales de Andrade, publicado pelo Governo do Estado de São Paulo, cuja temática se constrói nas lembranças do passado, contrapondo a vida urbana com a vida no campo, onde o cenário rural era idealizado como o melhor lugar para se viver na infância. Nessa esteira, Tales de Andrade valorizou o regionalismo, ao mesmo tempo em que demonstrou a preocupação com o crescimento rápido e desordenado dos centros urbanos.

Mas o grande nome que marcará o surgimento da Literatura Infantil brasileira é o de Monteiro Lobato, com a publicação de Narizinho arrrebitado.

\subsection{A PRESENÇA DA ILUSTRAÇÃO NA LITERATURA INFANTIL}

Um importante aspecto a ser considerado, neste estudo, tanto no contexto tradicional como no contemporâneo é a questão das ilustrações no livro de Literatura para crianças,

A contemplação do belo na arte gráfica, é uma atitude inerente ao ser humano. A natureza em si é uma obra de Arte. Ao homem é dada a liberdade de recriar, transformar e embelezar ainda mais essa obra prima da criação. O belo desperta a atenção e aguça a sensibilidade do ser humano, que é capaz de ad-mirar e contemplar. Valemo-nos da proposta de Góes ${ }^{40}$ : "O leitor da intertextualidade pode ad-mirar, pois tem os sentidos despertos, memória avivada e acionada, vendo o que existe, sem submeter-se às leituras-desvios, pois as detecta".

${ }^{40}$ GÓES, Lúcia Pimentel. Olhar de descoberta: proposta analítica de livros que concentram várias linguagens. São Paulo: Paulinas, 2003, p.24. 
Esse olhar admirador, que reconhece o belo, é fundamental nos livros para crianças. Eis porque um livro de literatura para crianças em fase inicial de escolarização (Ensino Fundamental I), necessita ser visualmente atraente, com boas ilustrações e bem coloridas, pois o fato de a criança pequena (pré-leitor) ser um iniciante no conhecimento do código lingüístico, a leitura de textos torna-se para ela um desafio. Se for extensa e sem espaço para um descanso, pode causar desinteresse e frustração, o que pode ser evitado. Daí a importância das ilustrações nos livros de literatura Infantil. Contudo, nem sempre foi assim. No contexto tradicional, as ilustrações eram raras e pouco ou nada coloridas; eram figurativas, redundantes, mas propiciando, já naquela época, uma comunicação não linear, próprio da linguagem imagética.

Algumas dessas ilustrações já eram verdadeiras obras de arte feitas com técnica clássica: à bico de pena, à óleo e outras.

Tomamos como referência O Patinho Feio ${ }^{41}$, publicado em 1915, pela editora Melhoramentos. Vale ressaltar, ainda, que é tido como o primeiro livro infantil com ilustrações em cores, no Brasil.
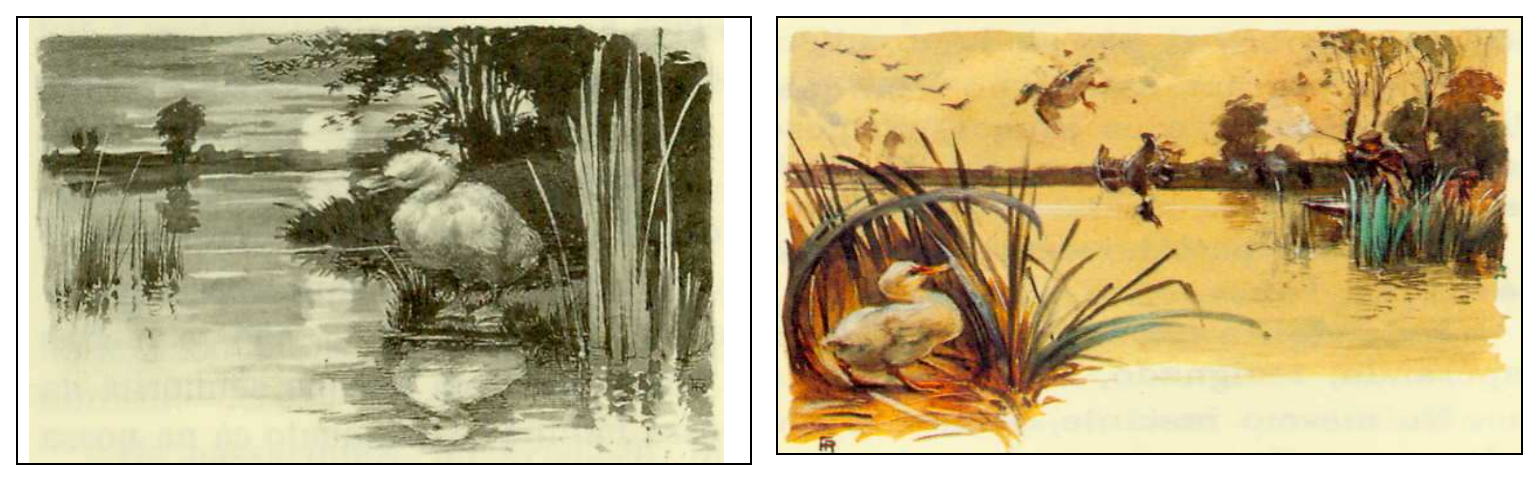

${ }^{41}$ ANDERSEN, Hans C. O Patinho Feio. São Paulo: Melhoramentos, 1915. 
Todavia, sequer o nome do ilustrador constava da capa do livro, como se pode ver na reprodução da capa a seguir, do livro, O Patinho Feio.

Paralelamente podemos constatar em O Menino que engoliu o quatro, publicação recente (2002), a parceria que existe entre autor e ilustrador: o nome de ambos aparece na capa.

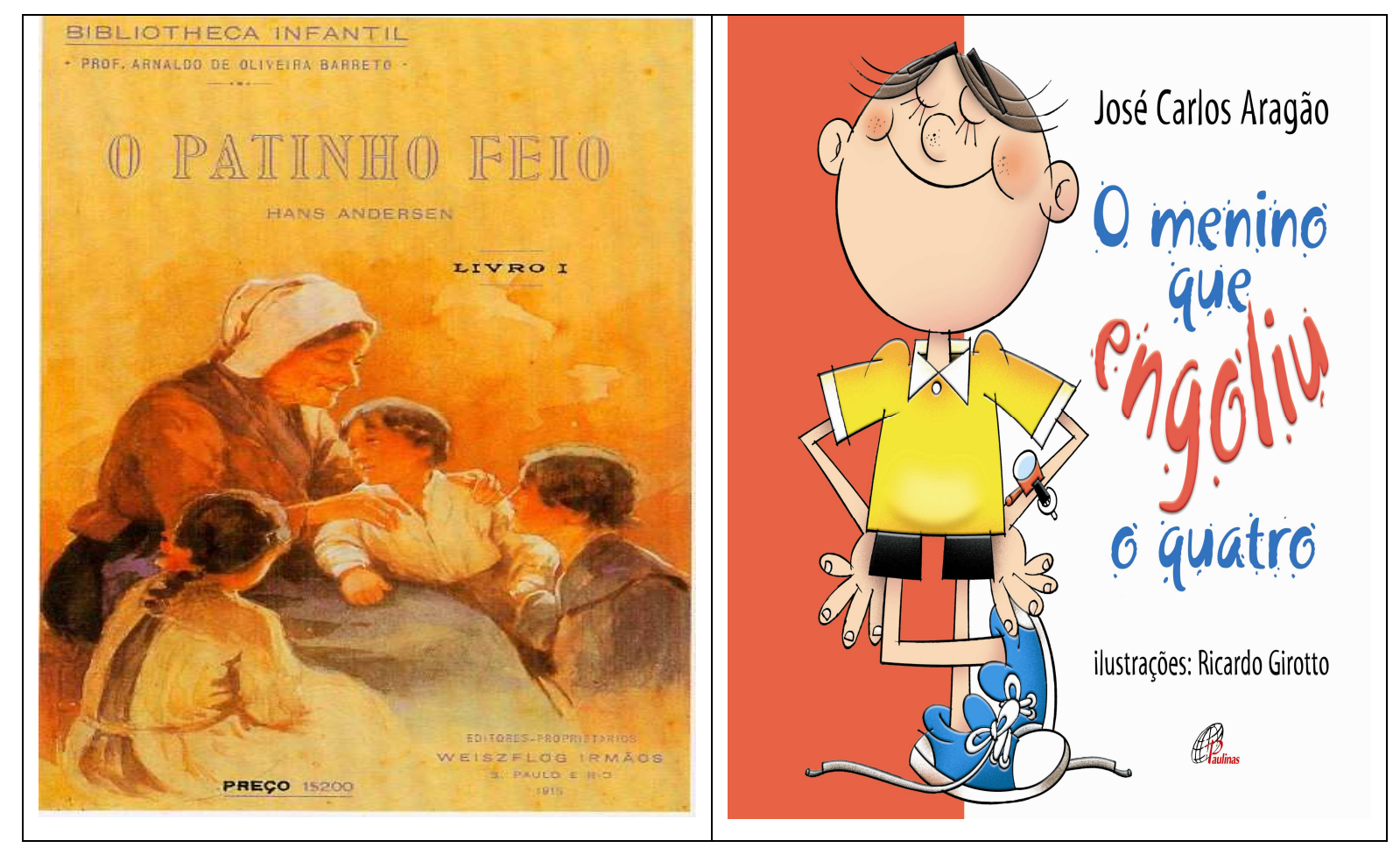

A ausência do nome do ilustrador já indica o pouco apreço a essa linguagem imagética, enquanto tal. Tudo se passava como se fosse parte do texto escrito, aliás, essa era a função das ilustrações em livros, naquela época: descrever e documentar o que foi escrito. A concepção tradicional de livro prendia-se, somente, ao texto escrito, conceito que ainda permanece até hoje em alguns segmentos de publicações.

Para exemplificarmos, relatamos uma experiência nossa em uma das Feiras de Livros onde uma criança pedia à mãe que comprasse um livro só de imagens, ao que a mãe respondeu: "- Não vou comprar, porque este livro não tem nada escrito." 
É, pois, fato constatável que a criança está muito mais aberta a essa proposta de leitura da linguagem imagética que o adulto, porque ainda não está condicionada à leitura linear (escrita), tendo ainda resguardada a liberdade de "passar pelas imagens" traçando seus próprios caminhos de leitura. Ler o texto, interpretar as imagens e interagir com a obra é intensificado pela presença da imagem, que nos permite compreender com WerneK ${ }^{42}$ que "A ilustração confere ao livro, além do seu valor estético, o apoio, a pausa e o devaneio tão importantes numa leitura criadora."

Com a evolução das ciências, das artes, da tecnologia, evoluiu também a concepção de ilustração de livros para criança. Hoje, a produção editorial está mais atenta à qualidade do livro, atende ainda mais às necessidades do leitor-criança e para tanto considera a qualidade artística da ilustração. Para a criação do texto imagético, recursos variados como: colagem, pintura e o auxílio da computação gráfica são utilizados. Há ilustradores que são verdadeiros pesquisadores, com o objetivo de que as ilustrações dialoguem com o conteúdo cultural da obra a ser ilustrada. Muitas ilustrações hoje são carregadas de metáforas, simbologia, cores, texturas, enfim, uma riqueza cada vez mais fascinante.

Esse cuidado faz-se necessário pela exigência do leitor que está mergulhado no mundo da mídia eletrônica, onde o acesso a jogos eletrônicos, programas infantis de TV cada vez mais atraentes, DVD's, internet são muito mais rápido sedutores.

A ilustração criativa permite ao leitor, criança ou não, invocar a imaginação, a fantasia, provoca o riso e o brincar, como é o caso de alguns livros imagéticos, onde a narrativa é constituída tão somente em linguagem visual. ${ }^{43}$

\footnotetext{
${ }^{42}$ WERNEK, Regina Yolanda. A importância da imagem nos livros de literatura infantil e juvenil. In Revista Tempo brasileiro, no 63, Rio de Janeiro, 1980, pp.90-97.

${ }^{43}$ FURNARI, Eva. Zuza e Arquimedes. São Paulo: Paulinas, 2000.

Idem. Amendoim. São Paulo: Paulinas, 2000.
} 

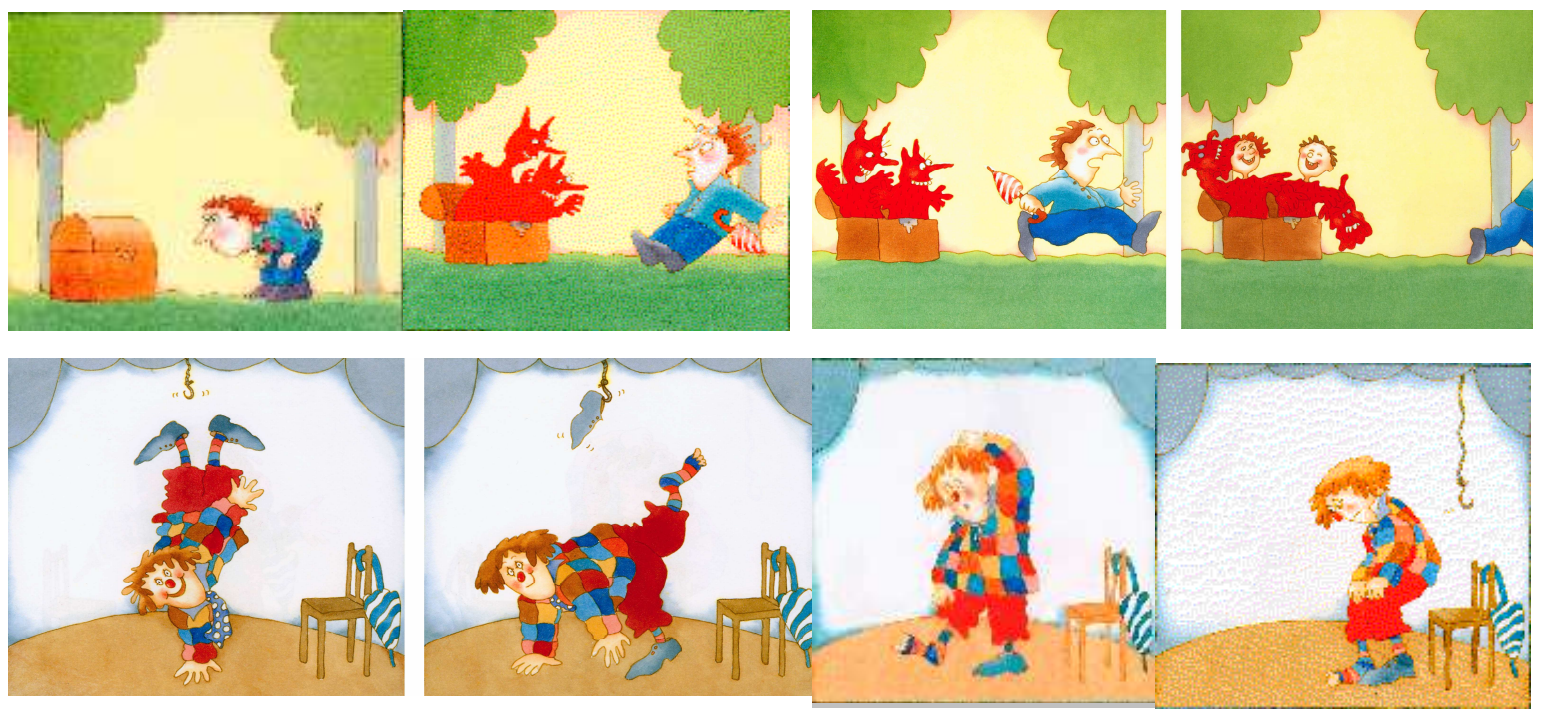

Inicialmente, essa proposta de livros só de imagens foi vista com reservas.

Muitas vezes, o livro de imagens é interpretado pelo adulto como um livro somente para crianças, que ainda não sabem decodificar o texto verbal, quando na verdade esse "objeto novo" oferece várias possibilidades de leituras, onde cada leitor fará a sua, de acordo com os seus referenciais culturais e emocionais. Falando da abrangência do livro imagético, Camargo ${ }^{44}$ escreve:

O livro de imagem não é um mero livrinho para crianças que não sabem ler. Segundo a experiência de vida de cada um e das perguntas que cada leitor faz às imagens, ele pode se tornar 0 ponto de partida de muitas leituras, que podem significar um alargamento do campo da consciência: de nós mesmos, de nosso meio, de nossa cultura e do entrelaçamento da nossa com outras culturas, no tempo e no espaço.

${ }^{44}$ CAMARGO, Luís. Ilustração do livro Infantil. Belo Horizonte: Lê, 1995, p.79. 
O adulto habituado às leituras lineares de texto escritos como de imagens não está familiarizado com a "leitura" ou decodificação dessa nova linguagem. A esse respeito, falando do livro como Arte, Góes ${ }^{45}$ afirma:

Arte da Palavra, que moderna e contemporaneamente foi passando por modificações introduzidas por outras tecnologias, indo da linguagem em quadrinhos à dos meios eletrônicos. O texto objeto real, com linguagem verbal, visual e grafotipográfica, extrapola o invólucro físico tradicional, seu suporte. Temos brinquedos-livros, jogoslivros, livros de pano e outros materiais somados a novas linguagens. A carência faz-se tanto em termos da desatualização teóricoprática, quanto do desconhecimento da instrumentalização didática que possibilite envolver alunos nessa atitude crítico-criativa, da leitura decifradora de códigos, integradora de sentidos.

No que diz respeito tanto ao conteúdo quanto à gráfica, à ilustração, a produção editorial deu um grande salto qualitativo em relação às primeiras produções voltadas para a Literatura Infantil. Salto que possibilitou as confluências de várias áreas artísticas e tecnológicas, preocupadas com o conteúdo e a forma, fazendo o melhor da produção editorial nessa área, buscando o equilíbrio entre essas linguagens que se complementam, como aponta Nelly Novaes Coelho ${ }^{46}$ referindo-se às novas tecnologias:

Após um período em que a imagem difundida pelos multimídias [...] parecia destinada a substituir definitivamente não só a palavra literária, mas o próprio livro como mediador nas relações humanas, a tendência agora é procurar a conciliação entre as duas, pois ambas as manifestações estão sendo descobertas como essenciais à formação e evolução cultural do ser humano, na sociedade letrada que caracteriza o mundo ocidental. Nesse sentido, não podemos esquecer que toda imagem "legível" necessita de um pensamento ou uma idéia a sustentá-la, explicá-la [...]

\footnotetext{
${ }^{45}$ GÓES, Lúcia Pimentel. Retrospectiva sobre a importância da imagem na história da humanidade. Disponível em: <www.tvebrasil.com.br/SALTO/boletins2002/lii/liitxt1.htm>, Acesso em: 15/09/2006.

${ }^{46}$ COELHO, Nelly Novaes. O Conto de fadas: símbolos, mitos, arquétipos. São Paulo: DCL, 2003, p.123.
} 


\subsection{O PAPEL DA IMPRENSA NA LITERATURA INFANTIL BRASILEIRA}

Inferimos de todo esse percurso literário infantil brasileiro que a imprensa foi um grande motivo para que muitos escritores publicassem seus primeiros textos literários infantis.

Já em princípio do séc. XIX $(1811)^{47}$, foi instalada no Brasil a primeira tipografia, na Bahia, com o periódico (bissemanal) O Adolescente. Embora o título faça referência, não há documentos que comprovem que se tratasse de um jornal voltado para jovens. Em 1937, O Recompilador ou Livraria dos Meninos, circulou em Salvador, sem deixar dúvidas que seu público alvo era as crianças.

${ }^{47}$ Entre os historiadores e pesquisadores consultados há divergências quanto ao ano exato de abertura da primeira tipografia no Brasil. Optamos pela informação, fruto da pesquisa, de Leonardo Arroyo. 


\subsection{MONTEIRO LOBATO, O ESCRITOR DA CRIANÇA BRASILEIRA}

“Nada de imitar seja lá quem for. [...] Temos de ser nós mesmos [...]. Ser núcleo de cometa, não cauda. Puxar fila, não seguir". Monteiro Lobato

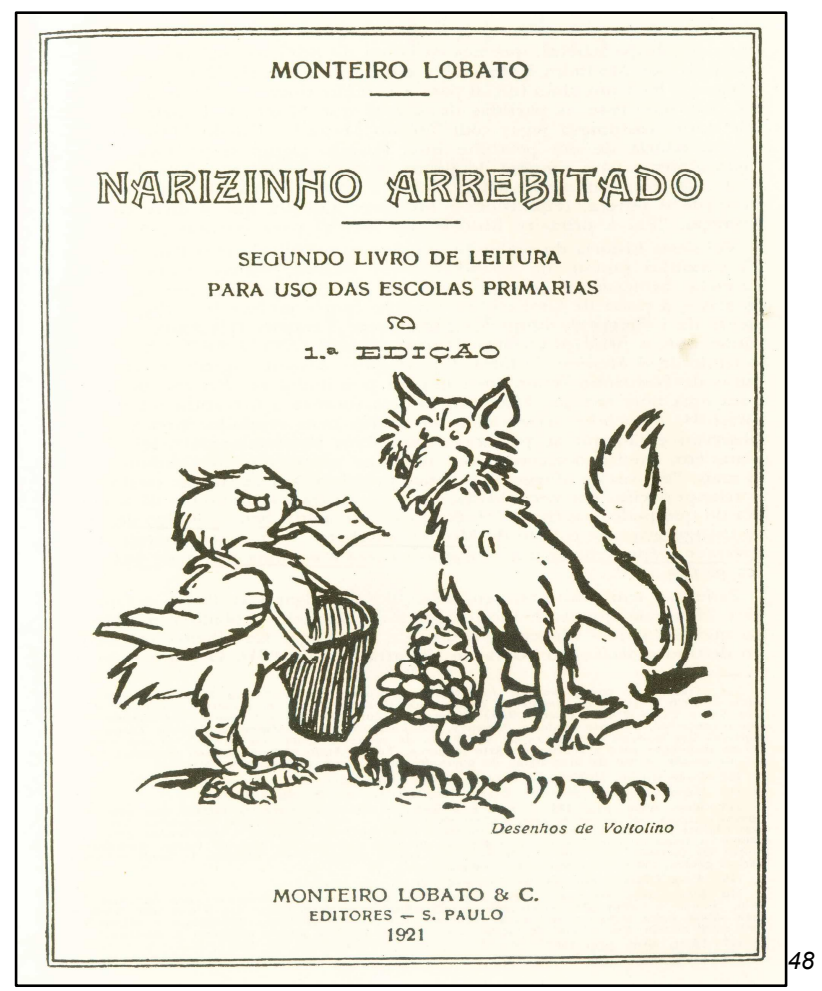

Na primeira edição do livro Narizinho Arrebitado, publicada em abril de 1921, havia impresso no frontispício, abaixo do título: "segundo livro de leitura para uso das escolas primárias". Seria polêmico pontuar esse livro como o marco da gênese da L.I. brasileira - livre do didatismo - com esse subtítulo explícito, indicando intenções escolares. Mas não o é, ou pelo menos, não o é se considerarmos a didática reprodutivista da época. Essa publicação histórica já tinha uma proposta de literatura bem distante daquela pedagógica e didática que, até então, se produzia no Brasil: a imaginação era o eixo central do enredo e a linguagem já era leve e espontânea como a

\footnotetext{
${ }^{48}$ Conforme fac-símile da página, impresso no livro Literatura Infantil Brasileira, de Leonardo Arroyo, p. 199.
} 
das crianças. Lúdica e livre das metodologias educacionais, não só Narizinho Arrebitado como os demais livros de Lobato ressoariam nos ouvidos e no coração das crianças daquela época. Com seu estilo conciso, vigoroso e intenso, com forte dose de ironia, linguagem clara e objetiva, suas obras conquistam, cada vez mais, leitores. Citamos uma passagem que expressa esse estilo lobatiano: ${ }^{49}$

[...] A vida, Senhor Visconde, é um pisca-pisca. A gente nasce, isto é, começa a piscar. Quem pára de piscar, chegou ao fim, morreu. Piscar é abrir e fechar os olhos - viver é isso. É um dorme-e-acorda, dorme-e-acorda, até que dorme e não acorda mais. É portanto um pisca-pisca. [...] A vida das gentes neste mundo, senhor sabugo, é isso. Um rosário de piscadas. Cada pisco é um dia. Pisca e mama; pisca e anda; pisca e brinca; pisca e estuda; pisca e ama; pisca e cria filhos; pisca e geme os reumatismos; por fim pisca pela última vez e morre. - E depois que morre? - perguntou o Visconde. - Depois que morre vira hipótese. É ou não é? O Visconde teve que concordar que era.

Sua irreverência e agudez de pensamento rompem com uma estrutura moralista de fazer literatura. Conhecedor do poder transformador de uma obra literária, Lobato avança na conquista de novos olhares, novos padrões de comportamento. Isso porque acreditava que a mudança não viria de cima para baixo, mas ao contrário. Acreditava no potencial da criança, se colocada em liberdade para elaboração de seus valores como indivíduo e cidadão. Não teme falar da realidade à criança. Por meio de suas personagens astutas, transgride as leis vigentes da sociedade com inteligência, sabedoria e espírito crítico. Uma passagem de Fábulas ${ }^{50}$ ilustra essa visão vanguardista de Lobato:

Dona Benta suspirou. - Meu filho, há duas espécies de literatura, uma entre aspas e outra sem aspas. Eu gosto desta e detesto aquela. A literatura sem aspas é a dos grandes livros; e a com aspas é a dos livros que não valem nada. Se eu digo: 'Estava uma linda ma-

\footnotetext{
${ }^{49}$ LOBATO, Monteiro. Memórias da Emília. 42.ed. São Paulo: Brasiliense, 1994, p.11.

${ }^{50}$ LOBATO, Monteiro. Fábulas. 48.ed. São Paulo: Brasiliense, 1994, p.18.
} 
nhã de céu azul', estou fazendo literatura sem aspas, da boa. Mas se eu digo: 'Estava uma gloriosa manhã de céu americanamente azul', eu faço 'literatura' da aspada - da que merece pau.

O fato é que, logo na primeira edição, dos 55.500 exemplares o Governo do Estado de São Paulo comprou 30.000 exemplares do livro Narizinho Arrebitado. Assim, podemos supor que aquele subtítulo fosse uma estratégia, até mesmo um indício do espírito empreendedor de Lobato, que anos mais tarde se lançaria como editor no mercado livreiro, com o mesmo ideal do escritor: ousado, provocativo, autêntico e combativo: "O que não somos nunca é ovelha - fiel ovelha do santo padre, de sua majestade o rei, do partido, da convenção social, dos códigos da moral absoluta, do bataIhão, de tudo que mata a personalidade das criaturas". ${ }^{51}$

Algumas aventuras de Narizinho, antes de se tornarem livro, foram publicadas inicialmente na Revista do Brasil. O que há de representativo nesses fragmentos, além da receptividade dos leitores é uma nota que Monteiro Lobato ${ }^{52}$ acrescentava aos textos:

A nossa literatura infantil tem sido, com poucas exceções, pobríssima de arte, e cheia de artifício - fria, desengonçada, pretensiosa. Ler algumas páginas de certos livros de leitura equivale, para rapazinhos espertos, a uma vacina preventiva contra os livros futuros. Esvai-se o desejo de procurar emoções em letra de forma; contrai-se o horror do impresso [...] Felizmente, esboça-se uma reação salutar. Puros homens de letras voltam-se para o gênero, tão nobre como outro qualquer.

\footnotetext{
${ }^{51}$ AZEVEDO, Paulo César (coord.). Monteiro Lobato vida, realidade e sonho. São Paulo: Emporium Brasilis Memória e Produção Cultural, 1998, p. 5.

${ }^{52}$ CAVALHEIRO,Edgar. Monteiro Lobato, vida e obra. 3.ed. São Paulo: Brasiliense, 1962, p.182. Apud. ARROYO, Leonardo Arroyo. Literatura Infantil Brasileira. São Paulo: Melhoramentos, 1988, p.200 - nota de rodapé.
} 


\title{
2.11.1 A criação do Sítio do Pica-pau Amarelo - espaço do imaginário infantil
}

\author{
“[...] e se eu fosse refazer a natureza, \\ igualava o mundo a isto aqui. \\ Vida boa, vida certa, \\ só no Pica-pau amarelo." \\ Pedrinho $^{53}$
}

Monteiro Lobato e Toledo Malta (engenheiro e escritor, também, da Revista do Brasil) costumavam jogar xadrez. Em um dos encontros, Malta contou-lhe a estória de um peixinho, que tirado do aquário provisoriamente, para limpeza, morreu afogado, pois durante aquele breve período fora do "lar", esquecera como nadar. Consta que essa pequena estória remeteu Lobato ${ }^{54}$ às lembranças da fazenda onde passara sua infância, em Taubaté. Daí, nasceram as primeiras sementes de criação do Sítio do Pica-Pau Amarelo.

Em carta a Godofredo Rangel, no ano de 1934, Lobato explica ao amigo as idéias que "não acabam mais":

[...] aventuras do meu pessoalzinho lá no céu, de astro em astro, por cima da via Láctea no anel de Saturno, onde brincam de escorregar... E a pobre da tia Nastácia metida no embrulho, levada sem que ela o perceba... A conversa da preta com Kepler e Newton, encontrados por lá medindo com a trena certas distâncias astronômicas para confundir o Albert Einstein, é algo prodigioso de contraste cômico. Pela primeira vez estou a entusiasmar-me por uma obra... Rangel, hás de estar estranhando o tom eufórico desta carta e pensarás que é o ferro ou petróleo que vem vindo around the córner. Nada disso. É a perspectiva do encontro da tia Nastácia com Isaac Newton que me põe de bom humor. Imagine a coitada lá pelos intermúndios, escorregando dum rabo de cometa, caindo de estrela em estrela e afinal aparada por um par de braços. De quem? De Sir Isaac Newton! E o Burro Falante, que andava gostando dela e com honestíssimas idéias de casamento, derruba as orelhas enciumado... Adeus, Rangel. A literatura ainda é o meu consolo... ${ }^{55}$

\footnotetext{
${ }^{53}$ LOBATO. 1954 , op. cit., p 30.

${ }^{54}$ Durante sua vida, Monteiro Lobato manterá intenso contato com seu amigo Godofredo Rangel, através de cartas. Essas epístolas foram reunidas e compõem um precioso acervo do processo de criação e de idéias do escritor e editor.

${ }^{55}$ LOBATO, Monteiro. A Barca de Gleyre: quarenta anos de correspondência literária entre Monteiro Lobato e Godofredo Rangel. São Paulo: Brasiliense,1948, p.328, tomo II.
} 
Através desse documento histórico, vemos a alma infantil, com toda a sua nobreza, habitando em Lobato. Se houve um adulto, "marmanjo", como ele mesmo dizia, que soube conservar a criança, mesmo adulto, permitindo-lhe espaço ilimitado para vazar as trancas do mundo adulto, esse foi Monteiro Lobato.

\subsubsection{Lobato, o editor}

Com seu espírito pioneiro e dotado de uma consciência de vanguarda, não demorou para que Lobato acreditasse no alcance do mercado editorial. Com o sucesso de seu livro Urupês, de literatura adulta, ele se entusiasmou e, de diretor da Revista do Brasil, tornou-se seu proprietário, em 1918. Assim, esse brasileiro, que demonstrava ousadia, não só enquanto escritor, possuía uma visão revolucionária frente à sua época. O livro para ele não era só um texto de bom conteúdo, mas também um produto com qualidade de produção.

Para Lobato, nem a criança nem a Literatura é algo menor, por isso prezava a qualidade literária e gráfica. Para ele esse produto cultural (o livro) era uma semente de transformação. Como semente deveria germinar e dar frutos; portanto, não bastava só editar bons livros; era preciso fazer chegar aos leitores. "Editar é o que existe de mais sério para um país. Editar significa multiplicar as idéias ao infinito, e transformá-las em sementes soltas ao vento para que germinem onde quer que caiam" ${ }^{56}$

Consciente da precariedade das edições dos livros não só do ponto de vista de conteúdos, mas de qualidade de capa, papel e traduções, Lobato constatou, ainda, a quase inexistência de livrarias no Brasil (àquela época, 1918, 50 pontos de venda). Em uma ação inédita, Lobato negociava a venda dos livros em caráter de

${ }^{56}$ AZEVEDO, op. cit., p.7. 
consignação, com agentes autônomos, e de forma contundente aproximava-se do leitor por "mala direta". O livro para ele era uma jóia.

A força de transformação de um povo está nas idéias que são propagadas, através dos livros que geram debates. Portanto, o empreendimento de Lobato no mercado de edição de livros era inevitável. Laura Sandroni ${ }^{57}$ o coloca como "o primeiro grande editor de autores brasileiros, não só na área de ficção, mas também na de História e Ciências Sociais".

Seu empreendimento em curto prazo alcançara o sucesso. A venda de suas publicações o impelia a investir cada vez mais no mercado editorial e, como vanguardista, Lobato importava equipamentos de ponta, sempre privilegiando a qualidade gráfica, além do conteúdo.

O triunfo das nossas edições está excedendo os meus cálculos; desde janeiro, 12 mil volumes vendidos: 4 mil Cidades Mortas, 4 mil Idéias de Jeca, 3 mil Urupês e mil Jeremias. (...) Estão a sair Sem Crime, de Papi Júnior, (...); Madame Pommery, uma obra prima de sátira bordelenga, do Toledo Malta ou 'Hilário Tácito': Tácito, porque aquilo é história, e Hilário porque é história alegre. (...) Ando a colaborar no Correio da Manhã e tive convite d'O Jornal. Cincoenta mil réis o artigo. ${ }^{58}$

Em 1924, o catálogo da editora abrangia diversas áreas; e muitos autores e escritores. Dentre eles: Manuel Antônio de Almeida, Alfonsus de Guimarães, Graça Aranha, Rodolfo Teófilo, Vicente de Carvalho, Menotti del Picchia, Hilário Tácito, Oswald de Andrade, Paulo Setúbal, Maria Eugênia Celso, Godofredo Rangel, Lima Barreto, Sud Menucci, Menotti del Picchia, Visconde de Taunay, Coelho Neto.

\footnotetext{
${ }^{57}$ SANDRONI, Laura. De Lobato a Bojunga - as reinações renovadas. Rio de Janeiro: Agir, 1987, p.48.

58 LOBATO. 1948, op. cit., p.215.
} 


\subsubsection{Lobato, o gênio}

A gênese de qualquer ciência ou arte não pode ser demarcada com dia, mês, ano e hora. A história não pode ficar compartimentada entre dois traços dentro de uma linha. Seria simplório imaginar que uma mudança, um movimento, uma revolução tenham sua certidão de nascimento. Idéias, opiniões, um parágrafo escrito aqui, outro acolá, uma conversa descontraída - como a ocorrida na partida de xadrez entre Monteiro e Malta - até mesmo deitado em uma rede nasce "a brisa" de novas mudanças.

Raros são os marcos decisivos no anúncio de novos valores e visões de mundo, mas Monteiro Lobato representa um marco para a L.I. brasileira. A começar pela sua concepção de criança que, contrária à visão míope de sua época, reconhecia nos pequenos a força da transformação; Lobato acreditava que através da Literatura e da Educação era possível conceber um mundo menos injusto e para isso a criança deve ser amada e respeitada. Segue um trecho que demonstra a relação compreensiva e amorosa entre Narizinho e Tia Nastácia: ${ }^{59}$

No sítio de Dona Benta havia vários pés, mas bastava um para que todos se regalassem até enjoar. Justamente naquela semana as jabuticabas tinham chegado 'no ponto' e a menina não fazia outra coisa senão chupar jabuticabas. Volta e meia trepava à árvore, que nem uma macaquinha. [...] Estava Narizinho no seu galho, distraída em pensar [...], quando levou à boca uma das tais furadinhas, com meia vespa dentro. Dessa vez em lugar do tloc do costume o que soou foi um berro - ailai!ai!... - Aposto que é vespa, sinhá! - disse tia Nastácia. Ela não sai da 'fruteira' e, como nunca foi mordida, abusa. Eu vivo dizendo: 'Cuidado com as vespas!' mas não adianta, Narizinho não faz caso. Agora, está aí... E foi correndo ao pomar acudir a menina. - Sossegue, boba, isso não é nada. Dói mas passa. [...] Indo dali há pouco ao rio com trouxa de roupa suja [...] Lá estava Narizinho trepada à árvore. Lá estavam as vespas com meio corpo metido dentro das frutas. [...] - Está tudo regulando! - murmurou consigo a preta, [...]

${ }^{59}$ LOBATO, Monteiro. Reinações de Narizinho. 50 ed. São Paulo: Brasiliense, 1994, pp. 22-23. 
Ao se expor, defendendo a criança, o seu direito de ler, de ser ela mesma, ele abriu espaço na literatura para que a voz infantil se fizesse presente: "Também vou fazer mais livros infantis. As crianças sei que não mudam. São em todos os tempos e em todas as pátrias as mesmas. As mesmas aí, aqui e talvez na China. Que é uma criança? Imaginação e fisiologia; nada mais". ${ }^{60}$

A L.I. de Lobato conseguiu cativar tanto o público infantil como o adulto, pela sua capacidade de comunicação com o leitor. Possuía uma linguagem extremamente rica, original, criativa, compreensiva e coloquial, carregada de realidade e sentimentos. Dotado de um espírito livre e inovador, Lobato não temia provocar debates que gerassem polêmicas no meio dos acadêmicos. Constatamos esse espírito inovador no trecho abaixo retirado de Fábulas ${ }^{61}$, de um diálogo entre Dona Benta com Pedrinho sobre formas cultas e populares na escrita:

- Os gramáticos querem que seja mostrengo - coisa de mostrar: mas o povo acha melhor monstrengo - coisa monstruosa, e vai mudando. Por mais que os gramáticos insistam na forma 'mostrengo', o povo diz 'monstrengo'. - E quem vai ganhar essa corrida, vovó? Está claro que o povo, meu filho. [...]

O cenário de suas histórias é o chão brasileiro, onde vive o povo simples, buscando resgatar suas raízes culturais. Nesse cenário, todos têm espaço: o pequeno e o grande, a criança, o jovem e o adulto. Espaço de liberdade, de sonho e de esperança para um mundo melhor.

Tratar da Literatura na Educação Tradicional e Contemporânea, no Brasil, sem falar em Monteiro Lobato, seria desprezar um marco decisivo na linha histórica.

Lobato para a L.I. Brasileira foi um profeta: antecipou os tempos, nas questões cultural e lingüística, e na visão crítica do mundo.

\footnotetext{
${ }^{60}$ LOBATO. 1948 , op. cit., p.322. Carta datada em 26/06/1930, quando Lobato estava em Nova York.

${ }^{61}$ LOBATO. 1994, op. cit., p. 9.
} 
Disseram dele Lessa, Teixeira, Drummond ${ }^{62}$ :

Lobato nunca fez literatura por literatura. Poucos escritores botaram tanta intenção, tanto sofrimento, tanta preocupação, tão sério amor, nos seus livros e nos seus artigos, como o fez ele, em sua literatura combativa e tantas vezes combatida. Orígenes Lessa

Monteiro Lobato pertencia a essa rara família de profetas e poetas, que condensam, de súbito, para um momento e um povo a sua própria essência espiritual. Anísio Teixeira

A lição maior de Lobato é a sua própria e tumultuosa riqueza humana. Creio mesmo que dentro de vinte anos, ele estará incluído nos manuais de história e cultuado na memória do povo, como uma espécie de herói civil da literatura.

\section{Carlos Drummond de Andrade}

E para aqueles que insistem em colocar Lobato na retaguarda do Movimento Modernista de 1922, eis o que disse Oswald de Andrade ${ }^{63}$ :

A Lobato deve muito o Brasil. Em primeiro lugar, o exemplo magnífico e raro do intelectual que não se vende e não se aluga, não se coloca a serviço dos poderosos e dos sabidos. Depois, foi ele um homem de ação e um descobridor. Devem-se a ele a campanha do livro e a campanha do petróleo. Foi ele o criador da nossa literatura infantil.

E, também, como todo profeta, foi perseguido pelo poder dominante de sua época.

${ }^{62}$ AZEVEDO, op. cit., texto quarta capa.

${ }^{63}$ Ibid., texto quarta capa. 


\title{
III - A LITERATURA INFANTIL CAMINHOS DA EDUCAÇÃO E DO ENSINO NO BRASIL
}

\subsection{PARADIGMAS DA EDUCAÇÃO}

A partir do século XV, segundo o historiador Ariès ${ }^{64}$, o ensino escolar passou a fazer parte de um todo social: "Dessa época em diante [...], a educação passou a ser fornecida cada vez mais pela escola. A escola deixou de ser reservada aos clérigos para se tornar o instrumento normal da iniciação social, da passagem do estado da infância ao do adulto."

As relações familiares, religiosas, escolares e sociais obedeciam a um determinado padrão de comportamento que consistia na obediência formal da criança, submissão e postura de inferioridade diante do adulto e/ou autoridade. Esses padrões perduraram por muito tempo e, de maneira explícita ou camuflada em certas culturas, permanecem até hoje.

Alencar et $a^{65}$ fazem da sociedade brasileira do final do século XIX e início do séc. XX uma descrição muito particular, porém, precisa:

\begin{abstract}
A maioria da população rural era de colonos, meeiros e posseiros, sem propriedades e sem leis que os protegessem, obrigados ao trabalho mal recompensado nas terras dos fazendeiros, sem instrução, vivendo na miséria. Dependiam dos coronéis para quase tudo: tratamento médico, licença para a plantação de uma roça, obtenção de um passe nas estradas de ferro e até de simples ajuda para escrever uma carta.
\end{abstract}

Esse padrão social, conseqüentemente, vai refletir no "olhar" que essa sociedade dirigia à Educação, cujas bases se amparavam tão somente na função de impedir o acesso da classe menos favorecida aos bancos escolares. Dentro desse

\footnotetext{
${ }^{64}$ ARIÈS, op. cit., p. 231.

${ }^{65}$ ALENCAR, Francisco et al. História da Sociedade Brasileira. Rio de Janeiro: Ao Livro Técnico, 1979, p.208.
} 
contexto, a Escola Tradicional assim funcionou até o início do século XX. Uma Educação que não visava transformar o indivíduo, era conteúdista, de modo a garantir o status quo do poder dominante da época. O ambiente escolar, que deveria ser um espaço de formação, era manipulado de forma que atendesse os interesses da classe dos poderosos - fazendeiros, juízes, políticos - cuja medida era dada pelo dinheiro, pelas posses, pela riqueza, pela herança. Era primordial resguardar essa posição e impedir a evasão dos bens. Representantes da "ideologia" do poder dominante ditavam as regras dos métodos educacionais para seus próprios filhos, reforçando no educando esse padrão de comportamento que garantiria a condição de poder da estirpe dos "coronéis". Para essa Educação Tradicional, o aluno era o único responsável pelo seu fracasso escolar. Os conteúdos não se relacionavam com a realidade do aluno e muito menos com o contexto social brasileiro: eram genéricos, abrangentes e informativos.

O professor era o dono do saber: ditava as normas e o aluno obedecia. A relação professor-aluno era vertical.

O método de ensino era expositivo - fala e giz -, exercícios repetitivos e formais; memorização de conceitos. Uma metodologia que trilhava na contramão dos objetivos da Educação, no sentido lato sensu: a formação do ser humano.

Com o avanço das pesquisas em Educação essa prática foi sendo questionada por vários teóricos, entre eles John Dewey, considerado um dos maiores pedagogos de séc.XX. Seu pensamento está voltado para os problemas educacionais no campo social e de formação humana. Para Dewey, a teoria tem que ser unida à prática. A Educação deve se servir também de outras ciências, como a Psicologia, a 
Sociologia e outras. Cabe ainda à educação a formação da consciência democrática do educando. Para Dewey ${ }^{66}$

A escola não pode permanecer alheia a essa profunda transformação da sociedade, mas deve ligar-se intimamente ao "processo social', mudando radicalmente sua própria forma. Ela deve 'tornar-se uma comunidade em miniatura, uma sociedade embrionária', mediante um contato mais estreito com o ambiente e com a realidade social do trabalho.

Essa nova visão da educação ganhou espaço mundial e chegou, também, ao Brasil.

Se as conquistas educacionais do fim do século XIX não se haviam estendido a todo Brasil, a proposta dos anos 20 e 30 não era simplesmente levar o 'modelo escolar' então construído a outras regiões. Mais que isso, o discurso 'escolanovista' operava resignificações em vários aspectos das inovações oitocentistas. ${ }^{67}$

Falando dos avanços na educação e de sua parceria com outras ciências, Cambi ${ }^{68}$ afirma:

Hoje, é impossível pensar os problemas educativos na forma tradicional, ligada a um saber pragmático e normativo ao mesmo tempo, predominante ou exclusivamente filosófico [...] eles devem ser pensados nos saberes empíricos, nas ciências de educação, para coIher a especificidade e a variedade dos problemas e para submetêlos a processos de análise e de intervenção que permitam soluções verificáveis, inspiradas numa lógica da experimentação e do controle científico, fazendo sair a intervenção pedagógica da condição dos bons propósitos e das ações ligada a critérios exclusivamente pragmáticos.

A partir dessa ótica, a Educação Contemporânea vê o educando como sujeito da própria educação; um ser em formação, que carrega consigo experiências culturais, em nível pessoal, familiar e social. Essa bagagem deverá estar relacionada com

\footnotetext{
${ }^{66}$ DEWEY, John. A escola e a sociedade. Apud CAMBI, Franco. História da pedagogia. Trad. Álvaro Lorencini. São Paulo: Unesp,1995, p.550.

${ }^{67}$ LOPES, Eliane Maria Teixeira et al. 500 Anos de Educação no Brasil. Belo Horizonte: Autêntica, 2003, p.514.

${ }^{68}$ CAMBI, Franco. História da Pedagogia. Trad. Álvaro Lorencini. São Paulo: Unesp, 199, p. 598.
} 
os conteúdos educacionais, em uma relação dialógica professor-aluno. É o que Libâneo ${ }^{69}$ confirma:

A escola de décadas atrás serviu aos interesses das camadas dominantes da sociedade e para isso estabeleceu seus objetivos, conteúdos, métodos e sistema de organização do ensino. Aos filhos dos ricos fornecia educação geral e formação intelectual, aos pobres, o ensino profissional visando o trabalho manual. A escola pela qual devemos lutar hoje visa o desenvolvimento científico e cultural do povo, preparando as crianças e jovens para a vida, para o trabalho e para a cidadania, através da educação geral, intelectual e profissional.

A cidadania só se concretiza num contexto democrático onde a educação busca, através do ensino escolar, formar sujeitos conscientes, autônomos, elaborativos e criativos. Segundo. Libâneo ${ }^{70}$

A democratização do ensino supõe um sólido domínio das matérias escolares, com especial destaque à leitura e à escrita, como précondição para a formação do cidadão ativo e participante. O ensino das matérias e o desenvolvimento das habilidades intelectuais contribuem para estabelecer os vínculos entre o indivíduo e a sociedade, e entre a sociedade e o indivíduo. Amplia no indivíduo a compreensão de suas tarefas no mundo material e social e alarga seus horizontes para perceber-se como membro de uma coletividade mais ampla que é a humanidade, para além de sua vivência individual e regional nas comunidades rurais e urbanas.

Teoricamente, as diretrizes da Educação Contemporânea são avançadas e transformadoras, contudo na prática, ainda há muitos desafios a serem superados, seqüelas do modelo da Educação Tradicional. A esse respeito, Penteado ${ }^{71}$ diz:

Acomodados a uma metodologia tradicional de ensino, em geral os alunos aguardam 'passivamente' que o professor decida o que vão fazer, com o que, por que e para que; ou porque têm dificuldade de expor suas idéias, seja pela pouca idade e incipiente domínio da linguagem oral e/ou escrita, seja mesmo pelo próprio fato de terem tido suas vozes sufocadas, ao longo da vigência do modelo tradicional [...]

${ }^{69}$ LIBANEO, José Carlos. Didática. São Paulo: Cortez,1994, p.44.

${ }^{70}$ Ibid., p. 44.

${ }^{71}$ PENTEADO. 2002, op. cit., p.118. 
Sintonizado com o pensamento de Penteado, Cambi $^{72}$ ratifica:

Toda atividade educativa deve partir do concreto para o abstrato, do simples para o composto, do conhecido para o desconhecido, e portanto todo o processo de simbolização deve ser aprendido através de um contato prolongado com a realidade e com os seus dados empíricos.

Dentre os problemas da Educação Contemporânea brasileira, um que salta aos olhos é a formação inicial do educador, e depois, no exercício de seu trabalho, quando não só necessita da atualização permanente imposta pela acelerada produção cultural própria da sociedade tecnológica, mas também por proceder de uma formação precária. De acordo com as diretrizes da Educação Contemporânea, exige-se que o professor tenha uma bagagem teórica capaz de responder não só aos conteúdos programados, mas de criar estratégias de aprendizagem ou de intercâmbio com seus alunos que ultrapassem uma metodologia pronta e acabada, como afirma Penteado ${ }^{73}$ :

Na metodologia comunicacional de ensino, a interação que se dá entre os sujeitos da educação, professor e alunos, por meio do agir comunicacional, das perguntas que vão sendo feitas a todo momento ao longo dos procedimentos docentes, permite identificar, no decorrer do processo, obstáculos e/ou problemas do processo de ensino possibilitando ajustes e/ou correções de rota no ato.

Isso nos leva a concluir que a prática docente precisa ser um aprendizado contínuo para que o professor possa se manter em constante atitude de diálogo: indagar, levantar hipótese, buscar, em conjunto com seus alunos, respostas a tantas perguntas, ao mesmo tempo em que questiona tantas respostas, provocando situações de impasse para que os alunos, uma vez confrontados, anseiem por encontrar soluções.

${ }^{72}$ CAMBI. op.cit., p.528.

${ }^{73}$ PENTEADO. 2002, op.cit., p.136. 
Em um mundo globalizado, no qual a sociedade atual está mergulhada em novas tecnologias mediáticas, só há sentido para a Educação se estiver inserida nesse contexto. Penteado ${ }^{74}$ escreve:

Ao se relacionar com o programa oficial na perspectiva da metodologia da comunicação escolar, o professor relaciona informação e conhecimento ali contidos com as informações que detêm dos alunos e com os conhecimentos deles, e com os próprios, estabelecendo um circuito em rede que resulta em reelaboração de conhecimentos discentes e docentes. Reelaboram os alunos o seu conhecimento de senso comum e o seu conhecimento escolar. Reelabora o docente os seus conhecimentos sobre o ensino e sobre o campo específico de sua disciplina.

Paralelamente à evolução de paradigmas da educação, também ocorreram mudanças na produção de L.I. Era então de se esperar que na atualidade o professor estivesse preparado para lidar com a L.I. de forma diferenciada e criativa. No entanto, na realidade atual o professor não recebe em seus cursos de formação inicial o preparo necessário para o trabalho criativo e formativo com a L.I.

Para agravar mais essa situação muitos livros, ainda hoje, vêm acompanhados de ficha de leitura que limita o trabalho a ser feito com o texto apenas na cobrança ou solicitação do nome do autor, nome da obra, dos personagens e alguns dados culturais da época e nada mais. Ou, ainda, o texto é usado apenas para exercício de gramática. Pensado para suprir a lacuna existente em relação à L.I. na formação de nossos professores, esse tipo de roteiro fechado inibe um trabalho mais ousado e criativo, a ser proposto para os alunos.

É preciso ressaltar que ainda hoje há professores que o procuram. A esse respeito Rocco $^{75}$ diz:

\footnotetext{
${ }_{74}^{74}$ PENTEADO. 2002, op.cit., p.189.

${ }^{75}$ ROCCO, Maria Thereza F. Literatura/Ensino: uma problemática. São Paulo: Ática, 1981, p.38.
} 
O fato de muitos professores afirmarem ser impossível escapar a isso pode parecer absurdo, porém é fácil entender sua proposição que se baseia em vários fatores: primeiro devido à inexistência de material melhor; segundo pela falta de tempo dos professores para preparar suas próprias aulas,se autoquestionar, questionar os textos escolhidos e dar suas próprias respostas, fora do esquema prêt-à-porter do 'Livro do professor'. Finalmente, pelo enraizamento desse sistema imposto que, pelas facilidades (antipedagógicas) apresentadas, domina qualquer outro tipo de tentativa que se venha a fazer para quebrar tal esquema, onde a estrutura fixa e dominante tem as seguintes características: 'Livro do Aluno' com espaços brancos, linhas pontilhadas, previstas para respostas de tamanho estandardizado, e 'Livro do Professor' com o mesmo espaço, já preenchido e, muitas vezes, por incrível que pareça, imitando letra de mão.

Diante de tais constatações, só podemos concluir que a L.I. não é compreendida no seu verdadeiro sentido e valor literário, que é mobilizar o fantástico, o mágico, o maravilhoso, o poético e o lúdico, por parte do autor, o que, no ensino escolar, precisa ser potencializado pela ação mediadora do professor entre aluno e obra.

Ação mediadora esta que deve ter início na análise da obra de L.I. a ser escoIhida e seguida do já aludido processo de intracomunicação do professor, de tal forma que possa proceder à escolha adequada de obra aos alunos que têm pela frente às exigências educacionais da sociedade em que se encontram.

Verifica-se que o conteúdo literário infantil, no curso de formação acadêmica do educador, é precário e praticamente ausente em certas instituições formadoras de professores. O roteiro de orientação para o ensino de Português no curso de formação de professores primários, na década de 60 do século passado, enfatizava os aspectos puramente históricos informativos da L.I. Sobre isso, Nelly Novaes CoeIho ${ }^{76}$ deixa registrado:

Examinando os vários itens do roteiro de orientação para a Cadeira de Português no 'Curso de Formação de Professores Primários', um,

${ }^{76}$ COELHO, Nelly Novaes. O ensino da Literatura. São Paulo: FTD, 1966, p.123. 
principalmente, chamou-nos a atenção, por estar a merecer um maior esclarecimento entre os professores. É o item i da parte Folclore e Literatura Infantil: [...] Se dermos maior importância aos aspectos puramente históricos do fenômeno acreditamos que o objetivo da inclusão da Literatura Infantil no Curso Normal estará completamente fraudado.

O alerta para o conhecimento da criança como um ser em desenvolvimento, ainda não estereotipado, espontâneo, aberto ao fantástico, ao maravilhoso, criador de conhecimento, se encontrava ausente nessas orientações. A Professora Nelly ${ }^{77}$, já naquela época, advertia sobre a função da L.I. como instrumento na educação:

A partir do conhecimento de certas peculiaridades comuns à psicologia da criança, será muito fácil aos futuros mestres, perceberem que a educação infantil, nas escolas, será muitíssimo ajudada pela leitura selecionada de contos maravilhosos, fábulas, contos de fadas, estórias fantásticas etc. A disposição instintiva da criança para aceitar as coisas mais espantosas e inverossímeis, com encanto e naturalidade, já faz com que ela se interesse muito mais prontamente por uma estória de pura e gratuita imaginação, do que pela literatura feita expressamente para educá-la e que visa abertamente dar-lhe alguma lição. Esse aspecto fantasia e imaginário das crianças deve ser ressaltado frente aos nossos alunos-normalistas, para que eles saibam como explorá-lo futuramente.

Analisando os documentos oficiais atuais que direcionam o ensino de Língua Portuguesa, não encontramos, explicitamente, nenhuma nota que aborde a questão do ensino, ou atividade cultural com a Literatura Infantil, o que consideramos uma falha, por ser ela um dos ingressos ao mundo do conhecimento e da cultura.

Com a Lei 5692/71, a L.I. é abordada como campo literário a ser incentivado na educação, como nos aponta Nelly Novaes Coelho ${ }^{78}$ : "A leitura, como habilidade formadora básica, é colocada como ponto de apoio das múltiplas atividades propostas aos alunos durante o processo de aprendizagem."

\footnotetext{
${ }^{77}$ Ibid., p.124.

${ }^{78}$ COELHO, Nelly Novaes. Panorama Histórico da Literatura Infantil Juvenil. São Paulo: Ática, 1984, p. 257.
} 
Os Parâmetros Curriculares Nacionais, do final do século XX (1997), enfatizam a importância de se trabalhar com a leitura em sala de aula: ${ }^{79}$

\begin{abstract}
A leitura é um processo no qual o leitor realiza um trabalho ativo de construção de significado do texto, a partir de seus objetivos, do seu conhecimento sobre o assunto, sobre o autor, de tudo o que sabe sobre a língua: característica do gênero, do portador, do sistema de escrita, etc. Não se trata simplesmente de extrair informações da escrita, decodificando-a letra por letra, palavra por palavra. Trata-se de uma atividade que implica, necessariamente, compreensão na qual os sentidos começam a ser construídos antes da leitura propriamente dita. Qualquer leitor experiente que conseguir analisar sua própria leitura constatará que a decodificação é apenas um dos procedimentos que utiliza quando lê: a leitura fluente envolve uma série de outras estratégias como seleção, antecipação, inferência e verificação, sem as quais não é possível rapidez e proficiência.
\end{abstract}

Enfatizam, ainda, a importância de criar condições favoráveis para o exercício de leitura. Para tanto, é preciso que os alunos tenham acesso aos materiais escritos, jornais, revistas, livros e outros. Daí a importância de se criar nas escolas uma biblioteca onde os alunos possam ter acesso a esse material.

Nesse início do terceiro milênio, o Governo Federal, através do Ministério da Educação e Ministério da Cultura, criou um Plano Nacional do Livro e Leitura (P.N.L.L.) com a Lei 10.753 (2003). Esse Plano propõe incrementar, expandir e subsidiar projetos de incentivo à leitura de modo que

[...] a adoção, pela primeira vez na história do País, de um Plano Nacional do Livro e Leitura capaz de sistematizar, integrar, promover sinergia, dar maior visibilidade e, portanto, otimizar e conferir maior eficácia às ações desse setor, pode ser considerada um desdobramento natural das comemorações do Ano Ibero-Americano da Leitura.

\footnotetext{
${ }^{79}$ Ministério da Educação e do Desporto. Secretaria de Educação Fundamental Parâmetros Curriculares Nacionais - Língua Portuguesa, Brasília, 1997, p. 41.

* Comemorado no Brasil em 2005.
} 
Preconiza-se hoje a exploração do fantástico, do lúdico, da fantasia que são as metas da interação participativa do aluno com a obra, explorando o sabor literário. Conforme já estudado em nossa dissertação de mestrado ${ }^{80}$, já publicada em livro, simples contato do aluno com a história infantil, seja através da leitura, seja da audição ou da recepção via mídia, como TV, cinema, teatro, já constitui uma forma de interação com seus aspectos formativos e informativos, desde que ela tenha significado para ele. E um texto significativo é aquele que na sua incompletude permite ao leitor incursionar por sua bagagem de vida pessoal, histórica e cultural, possibilitando novas experiências e re-elaborações.

O aluno leitor, hoje, na perspectiva de uma educação que o respeite enquanto ser em desenvolvimento e como agente criador, produto e produtor de cultura, é valorizado como um ser em processo de construção do conhecimento de si próprio e do mundo que o cerca. Essa nova perspectiva é contemplada hoje, de maneira artística, na L.I. Contemporânea.

\subsection{A DEFASAGEM ENTRE A ESFERA LITERÁRIA E A EDUCACIONAL}

Ao compararmos a inovação ocorrida na esfera da Literatura, no início do século XX - patente na criação lobatiana e no Modernismo de 22 - com a persistência do sistema educacional tradicional, até quase o nosso tempo, facilmente se comprova que "a arte é sempre arauto das novas formas da vida em evolução." ${ }^{81}$ A invenção precede de muito a concretização das idéias inventadas.

É dentro dessa ordem de problemas que se insere o conjunto de análises que são o principal objetivo desta tese.

\footnotetext{
${ }^{80}$ OLIVEIRA, Maria Alexandre. Leitura Prazer: Interação participativa da criança com a Literatura Infantil na escola.. $3^{\text {a }}$ ed. São Paulo: Paulinas, 2006.

${ }^{81}$ Conforme apostila da Profa. Nelly Novaes Coelho, 1999.
} 
Partindo das considerações anteriores, procuramos contribuir com este trabaIho para o processo de formação do leitor infantil, adequado para o desenvolvimento do gosto e do prazer da leitura da L.I., elaborando, desse modo, os alicerces para aquisição do gosto estendido para leitura ao longo da vida.

Especificamente, as análises neste trabalho das obras selecionadas procuram explicitar ao professor:

- o alcance da L.I. no desenvolvimento pessoal (construção de identidade) e social da criança (formação para a cidadania);

- critérios a serem observados no momento da escolha de texto a ser trabaIhado junto às crianças, que resultem em seleção da obra com qualidade literária e condizente com os propósitos de ensino e as possibilidades cognitivas dos alunos;

- e as profundas relações existentes entre Literatura do passado e a do presente, evidenciando que nossa vida é fruto do ontem e o que fazemos no presente está criando o futuro.

Pretende-se assim firmar que o trabalho docente com a L.I. tem início em momento anterior à sua realização em sala de aula. Para tanto, esperamos oferecer algumas "chaves" ou " critérios de escolha" orientadores dessa $1^{\text {a }}$ etapa; espera-se provocar o professor para que ele se torne um agente consciente do processo educativo da e com L.I.. Para que assim ele possa criar uma metodologia de ensino da L.I., que estabeleça relações dinâmicas entre o texto literário, o imaginário do leitor e o contexto humano-sócio-cultural a que ele pertence. 


\section{IV - METODOLOGIA}

[...] em termos de relação pedagógica no contexto da escola, nada texto audiovisual, técnica ou tecnologia - substitui a palavra do professor, sua presença, seu exemplo, seu conhecimento e seu testemunho nos momentos das práticas educativas. Quero dizer com isto que o professor, enquanto mediador no processo de produção de conhecimento, e enquanto interlocutor que nomeia, conta, aponta coisas, organiza idéias, faz um grupo avançar, etc. constitui-se, ele próprio no principal 'livro' a ser lido e estudado pelos alunos. ${ }^{82}$

Daí a necessidade de o professor estar ciente quanto ao valor da L.I. para formação da visão de mundo do aluno, tendo em vista que a Literatura expressa os valores que dirigem a vida humana e a sociedade.

\subsection{OBJETO DA PESQUISA:}

Obras de Literatura Infantil produzidas do início do séc. XX ao início do séc. $\mathrm{XXI}$ e tradicionais contos infantis, como contos de fada e contos maravilhosos, componentes do universo cultural de nossas crianças.

\subsection{OBJETIVOS}

\section{Gerais:}

1- Propiciar aos professores um aprofundamento do conhecimento da L.I. e do trabalho com ela no contexto educacional de ensino;

2- Subsidiar o trabalho de professores com a L.I. junto aos alunos, destacando o seu potencial formativo junto às crianças.

\section{Específicos:}

1- Disponibilizar alguns possíveis critérios para escolha de obras infantis a serem trabalhadas em sala de aula que satisfaçam as exigências essenci-

\footnotetext{
${ }^{82}$ SILVA, Ezequiel Theodoro. De olhos abertos. São Paulo: Ática, 1991, p.20.
} 
ais para serem consideradas L.I. e sejam adequadas aos propósitos de ensino;

2- Apresentar sugestões de propostas pedagógicas que levem os professores a criar atividades formativas com a L.I.

\subsection{PERGUNTAS DE PESQUISA}

Para atender tais objetivos, elaboramos as seguintes perguntas de pesquisa:

1. Em que quadro de paradigmas educacionais se situa a obra de L.I. a ser trabalhada?

2. Quais as propriedades literárias e formativas da obra de L.I. a serem desenvolvidas em sala de aula?

3. Como o professor poderá identificar a adequação de determinada obra de L.I. aos propósitos do processo de ensino-aprendizagem requerido pelo estágio atual da sociedade brasileira?

\subsection{PROCEDIMENTOS METODOLÓGICOS}

\section{Critérios de escolha das obras a serem analisadas}

Por ser o livro de L.I. ao longo do período definido para a pesquisa - início do séc. $X X$ ao início do séc. $X X I$ - nosso objeto de pesquisa, iniciamos nosso trabalho planejando onde deveríamos buscar o acervo de obras que precisávamos para o trabalho.

Pelo levantamento dos títulos definidos para essa pesquisa, contatamos, no período inicial, via correio eletrônico, as editoras com publicação de obras da L.I. no período considerado: Melhoramentos, Martins Fontes e Francisco Alves. Apresentamos informações sobre a pesquisa. Solicitamos permissão para acesso ao arquivo de produção infantil de cada uma delas para fins da pesquisa. 
Por razões não esclarecidas, apenas a editora Martins Fontes colocou-se à disposição. As outras se omitiram, não respondendo ao pedido, enviado formalmente,

Diante da dificuldade de acesso ao livro no arquivo das próprias editoras, decidimos fazer o levantamento do acervo via pesquisa, na internet. A partir do levantamento e da seleção dos livros de L.I. produzidos no período selecionado para estudo, partimos em busca desse acervo nas Bibliotecas da cidade de São Paulo. Visitamos a Biblioteca da Faculdade de Filosofia, Letras e Ciências Humanas da Universidade de São Paulo, a Biblioteca Monteiro Lobato e o arquivo de Paulinas Editora. Os critérios de escolha dos livros foram:

- $\quad$ ano de publicação;

- preferência por obras de escritores brasileiros.

Iniciamos a coleta de dados selecionando, primeiramente, o ano da publicação. Eis o primeiro percalço: as edições não vinham com ficha catalográfica e as obras encontradas não informavam a data da $1^{a}$ publicação, nem mesmo a data das reedições.

Fomos, então, em busca de estudos teóricos, já realizados, que fornecessem os dados, minimamente possíveis, para localização do período da obra. O Dicionário Crítico da Literatura Infantil e Juvenil brasileira ${ }^{83}$, da Professora Nelly Novaes CoeIho, permitiu-nos, na maioria das vezes, situar no tempo obras que consideramos relevantes para o desenvolvimento de nosso trabalho, que tem por meta verificar as características literárias e os valores nelas contidos e as possibilidades de exploração em sala de aula de forma interativa, lúdica e criativa, incentivando o prazer da

\footnotetext{
${ }^{83}$ COELHO, Nelly Novaes. Dicionário crítico da literatura infantil e juvenil brasileira:
} século XIX e XX. 4.ed. São Paulo: EDUSP, 1995. 
leitura, em contraposição a um ensino mecânico e formal, limitado aos aspectos gramaticais, que acabam por afastar a criança da Literatura.

\subsubsection{Tipo de pesquisa}

Optamos por realizar uma pesquisa qualitativa sobre as obras de L.I. aqui selecionadas. Por ser um registro estável, a pesquisa qualitativa caracteriza-se por considerar o pesquisador o principal mediador entre o objeto de pesquisa e os resultados dos dados pesquisados. Prevê um contato intenso do pesquisador com o objeto de pesquisa, permitindo a ele um maior envolvimento no processo e possibilitando um mergulhar mais profundo no desenvolvimento de significados procurados.

Nesse tipo de pesquisa, o rigor do processo realizado é o que conta para a aquisição do conhecimento a se obter, exigindo do pesquisador muita atenção e perspicácia.

O pesquisador nessa Metodologia é cauteloso ao afirmar os resultados de sua análise processual e indutiva. A esse respeito nos orienta Wittrock ${ }^{84}$ :

La investigación de campo interpretativa exige ser especialmente cuidadoso y reflexivo para advertir y describir los acontecimientos cotidianos en el escenario de trabajo y para tratar de identificar el significado de las acciones de esos acontecimientos desde los diversos puntos de vista de los proprios actores.

Reforçando o papel do pesquisador, Lüdke ${ }^{85}$ afirma: "O papel do pesquisador é justamente o de servir como veículo inteligente e ativo entre esse conhecimento acumulado na área e as novas evidências que serão estabelecidas a partir da pesquisa".

Por ser a L.I., nosso objeto de pesquisa, um registro estável podendo ser compreendido como um documento de época, possível de ser consultado quantas

\footnotetext{
${ }^{84}$ WITTROCK, Merlin C. La investigación de la enseñanza, II - Métodos cualitativos y de observación. Trad.Glória Vitale. Barcelona: Ediciones Paidós Ibérica, 1989, p.199.

${ }^{85}$ LÜDKE, Menga et ANDRÉ, Marli E.D.A. Pesquisa em Educação: abordagens qualitativas. São Paulo: EPU, 1986, p.05.
} 
vezes se fizer necessário, adotamos neste trabalho procedimentos da análise documental. A análise de documentos escritos, "pode se constituir numa técnica valiosa de abordagem de dados qualitativos, seja complementando as informações obtidas por outras técnicas, seja desvelando aspectos novos de um tema ou problema". ${ }^{86}$

Segundo Caulley ${ }^{87}$ "a análise documental busca identificar informações factuais nos documentos, a partir de questões ou hipóteses de interesse."

Em se tratando de uma pesquisa documental, procuramos encontrar nos textos selecionados de L.l., valores e significados próprios dos contextos históricosociais em que as obras foram produzidas, e que explicitassem as propriedades formativas que sustentam as mensagens veiculadas.

Partimos da hipótese, segundo a qual, a ausência ou frágil presença de preparo para o trabalho escolar com a L.I., na formação de professores do Ensino Fundamental, coloca as necessidades :

a) de elaborar uma periodização da L.I. brasileira, a partir de critérios levantados pela análise documental das obras;

b) de disponibilização desses critérios e do modo de atuação com eles de forma a possibilitar ao professor um instrumento, para proceder, ele mesmo, à análise de obras, possibilitando escolhas adequadas aos propósitos de seu trabalho docente com a L.I.

$\mathrm{Na}$ análise da obra realizada, tivemos por meta identificar:

- o contexto sócio-histórico-cultural em que foi produzida;

\footnotetext{
${ }^{86}$ LÜDKE.OP.CIT., p.38.

${ }^{87}$ CAULLEY,D.N. Document Analysis in Program Evaluacion ( $N^{\circ} 60$ na série Paper and Report Series of the Research on Evaluacion Program). Portland: Or. Northwest Regional Educational Laboratory,1981. apud LUDK, Menga e ANDRÉ, Marli E.D.A. Pesquisa em Educação: abordagens qualitativas. São Paulo: EPU, 1986, p.38.
} 
- a temática que a sustenta, valores e ideologia implícitos ou explícitos;

- características literárias/comunicacionais que englobam aspectos artísticos e de editoração gráfica;

- situar a obra nos respectivos quadros de paradigmas Educacionais Tradicional e Contemporâneo.

Tais propósitos implicaram, também, em análises de documentos oficiais, tais como: Lei de Diretrizes e Bases da Educação Nacional de 1990, Parâmetros Curriculares Nacionais - Língua Portuguesa (1997), Plano Nacional do Livro e da Leitura (2003) e Proposta Curricular para o Ensino de Língua Portuguesa, $1^{\circ}$ Grau - Secretaria de Estado da Educação - São Paulo - Coordenadoria de Estudos e Normas Pedagógicas (1991), Lei de Diretrizes e Bases da Educação Nacional n 5.692/71, Lei de Diretrizes e Bases da Educação Nacional n 9.394/96, Legislação do Ensino: uma introdução ao seu Estudo (1987) sobre Diretrizes Gerais do Ensino de programas oficiais de ensino de Língua Portuguesa para as séries iniciais do Ensino Fundamental I.

O trabalho deverá resultar na elaboração de quadro referencial de critérios de análise e de classificação da obra de L.I., de modo a possibilitar ao professor a escoIha de obras adequadas às necessidades formativas de seus alunos e condizentes com as possibilidades afetivo/cognitivas de suas faixas etárias. A esse respeito adverte-nos a Nelly Novaes Coelho: ${ }^{88}$

[...] ao usarem no Curso Primário, a leitura e comentário ou a narração daquela literatura infantil feita expressamente para agradar à criança, estarão os mestres conseguindo um triplo resultado: divertindo, educando e instruindo ao mesmo tempo. O que se faz necessário nesse sistema é que o mestre saiba explorar os vários aspec-

${ }^{88}$ COELHO. 1966, op. cit., p.125. 
tos das leituras, no sentido de ligar aquelas experiências realizadas no plano do maravilhoso das estórias às experiências comuns da criança, no plano das relações humanas. Desse modo ela irá gradativamente assimilando noções de comportamento humano, de conhecimentos vários; adquirindo o senso da reflexão e o que é mais importante, formando uma tabua de valores, sobre os quais erguerá seu futuro comportamento individual e social.

No aspecto formativo da L.I., também, há de se considerar que ela possibilita inter-relacionar conhecimentos de diferentes campos cognitivos, permitindo ao leitor lidar com a realidade em sua complexidade, e ao professor superando, através do trabalho didático, as limitações da fragmentação de ensino disciplinar.

Nossa pesquisa visa propiciar um aprofundamento do conhecimento da L.I. pelos professores, que colabore com a qualificação do Ensino da L.I. para a criança, partindo da escolha consciente das propriedades da obra, considerando a interação que o aluno deverá ter com ela. Temos por meta contribuir com a qualificação da prática docente no trabalho com a L.I., enquanto obra aberta.

Para Góes ${ }^{89}$ obra aberta é

[...] aquela que tessitura, tecido de múltiplos fios-ponto-devista.Multiplicidade que está nas personagens, na linguagem, no narrador. Que respeite a liberdade do leitor, que se colocará, com sua opção resguardada diante do texto, podendo refletir à vontade, sem constrangimentos.

\subsubsection{Obras selecionadas}

Chegamos, então, a uma seleção de obras que contemplassem livros cujos temas e conteúdos revelam parâmetros tradicionais da L.I. que se caracterizam por

${ }^{89}$ GÓES, Lúcia Pimentel. A aventura da literatura para crianças: formas de avaliação da literatura infantil e juvenil através da obra de Francisco Marins. São Paulo: Melhoramentos, 1990, p.16. 
uma "Literatura de dominação"; e, obras que se enquadram em parâmetros contemporâneos, caracterizados por uma "Literatura emancipadora".

Compõem essa seleção, obras do início do séc. XX ao início do séc. XXI. Inclui também contos considerados de Literatura Clássica Infantil, por abordar questões universais e por fazer parte do imaginário popular infantil brasileiro.

As fábulas têm sua origem na oralidade. O gênero se caracteriza pela presença de uma moral explícita. Sobre isso a profa. Nelly Novaes Coelho ${ }^{90}$ esclarece: "Fábula [...]é a narrativa (de natureza simbólica) de uma situação vivida por animais, que alude a uma situação humana e tem por objetivo transmitir certa moralidade." A escolha de textos desse gênero já aponta conteúdos para explicitamente didático-moralistas.

Para a seleção de livros que representassem os parâmetros educacionais contemporâneos, procuramos obras editadas a partir de 1970, data em que teve início o reconhecimento da produção da L.I. renovada de Lobato e o período emancipador da L.I. no Brasil. Optou-se por textos que abordassem temas e valores contemplados em livros publicados anteriormente, para evidenciar diferença de paradigmas ao longo do tempo. Estivemos também atentos ao surgimento de novos temas reveladores de novas necessidades sociais.

Consideramos também a importância de analisar textos da Literatura Clássica Infantil, ainda que produzidas por autores estrangeiros, em virtude de sua presença constante, através dos tempos, entre os contos apresentados às nossas crianças até hoje, e pelo interesse e gosto que despertam. Por isso, a análise de alguns destes textos foi considerada imprescindível, em um estudo que visa esclarecer as possibilidades formativas da L.I.

${ }^{90}$ COELHO, Nelly Novaes. Literatura Infantil: teoria, análise, didática. São Paulo: Moderna, 2002, p.165. 
Com referência aos clássicos infantis ${ }^{91}$, segundo a classificação da professora Nelly, selecionamos para o nosso trabalho dois contos de cada um dos seguintes recolhistas: Charles Perrault, os irmãos Grimm e Hans Christian Andersen, pela constante presença entre os demais textos infantis conhecidos por nossas crianças.

${ }^{91}$ COELHO. 2003, op. cit., p.79. 


\subsection{CLASSIFICAÇÃO DAS OBRAS SELECIONADAS EM PERÍODOS}

\section{Quadro 1 - Obras localizadas em períodos}

Procedemos, a seguir, a localização das obras selecionadas para a pesquisa, em três períodos:

\begin{tabular}{|c|c|c|c|c|c|}
\hline Contexto & Título da Obra & Autor & Ilustrador & Editora & $\begin{array}{c}\text { Ano de Publica- } \\
\text { ção }^{92}\end{array}$ \\
\hline \multirow{6}{*}{$\begin{array}{c}0 \\
0 \\
\frac{0}{0} \\
\frac{10}{0} \\
0\end{array}$} & O Pequeno Polegar & Charles Perrault & Andréa Vilela & Paulus & 2005 \\
\hline & $\begin{array}{l}\text { O Mestre Gato ou Gato de } \\
\text { Botas }\end{array}$ & Charles Perrault & Andréa Vilela & Paulus & 2005 \\
\hline & A Gata Borralheira & Jakob e Wilhelm Grimm & $\begin{array}{l}\text { Janusz Grabi- } \\
\text { anski }\end{array}$ & Paulus & 1989 \\
\hline & Chapeuzinho Vermelho & Jakob e Wilhelm Grimm & $\begin{array}{l}\text { Janusz Grabi- } \\
\text { anski }\end{array}$ & Paulus. & 1989 \\
\hline & O Patinho Feio ${ }^{93}$ & Hans C. Andersen & Franta Richter & Melhoramentos & 1915 \\
\hline & O Guardador de porcos & Hans C. Andersen & $\begin{array}{l}\text { Vilh.Pedersen e } \\
\text { Lorenz Frolich }\end{array}$ & Paz e Terra & 2002 \\
\hline \multirow{13}{*}{$\frac{\sqrt{0}}{\frac{0}{0}}$} & A Galinha Ruiva & Paul Bilder & $\begin{array}{l}\text { Eliana B. Bran- } \\
\text { dão }\end{array}$ & Melhoramentos & [19..] \\
\hline & $\begin{array}{l}\text { Paulina pega-fogo } \\
\text { Apud João Felpudo }\end{array}$ & Heinrich Hoffmann & Dorca & Melhoramentos & [1921] \\
\hline & $\begin{array}{l}\text { Tonico balança-e-cai } \\
\text { Apud João Felpudo }\end{array}$ & Heinrich Hoffmann & Dorca & Melhoramentos & [1921] \\
\hline & $\begin{array}{l}\text { O Negrinho } \\
\text { Apud João Felpudo }\end{array}$ & Heinrich Hoffmann & Dorca & Melhoramentos & [1921] \\
\hline & O Porquinho Dorminhoco & Edna Groff Deihl & $\begin{array}{l}\text { A.E.Kennedy } \\
\text { e Roberta Paflin }\end{array}$ & Melhoramentos & $\begin{array}{l}\text { [ s.d.], ano do } \\
\text { original em } \\
\text { inglês } 1925\end{array}$ \\
\hline & O Menino mal criado & Desconhecido & Não citado & Francisco Alves & 1932 \\
\hline & A carteira perdida & Frei Idelfonso & Não citado & Paulinas & 1943 \\
\hline & Bitu, o carneirinho sujo ${ }^{94}$ & $\begin{array}{l}\text { Maria Thereza Cunha } \\
\text { Giácomo }\end{array}$ & Darcy Penteado & Melhoramentos & [s.d.] \\
\hline & O Burrinho Verde ${ }^{95}$ & $\begin{array}{l}\text { Maria Thereza Cunha } \\
\text { Giácomo }\end{array}$ & Hilda Benett & Melhoramentos & [s.d.] \\
\hline & O galo de casa & Não identificado & Não citado & Paulinas & 1957 \\
\hline & Nhá Dita contou & Odete de Barros Mott & Não citado & Paulinas & 1962 \\
\hline & Chiquinho o mexe-mexe & Angelino Cotoweski & Joselito & Vozes & 1963 \\
\hline & Lição merecida & Angelino Cotoweski & Joselito & Vozes & 1963 \\
\hline
\end{tabular}

\footnotetext{
92 Para os textos clássicos, o ano de publicação informado é o mesmo dos livros consultados. Para os textos dos períodos Tradicional e Contemporâneo foi considerado o ano da $1^{\text {a }}$ edição.

93 Edição de comemoração dos 100 anos de publicação do título (2003), publicada tal qual 1915.

${ }^{94}$ Conforme Dicionário crítico da Literatura Infantil e juvenil brasileira de Nelly Novaes Coelho, o livro foi publicado em 1955, ( p.765).

${ }^{95}$ Conforme Dicionário crítico da Literatura Infantil e juvenil brasileira de Nelly Novaes Coelho, o livro foi publicado em 1955, ( p.765).
} 


\begin{tabular}{|c|c|c|c|c|c|}
\hline Contexto & Título da Obra & Autor & Ilustrador & Editora & $\begin{array}{c}\text { Ano de Publica- } \\
\text { ção }\end{array}$ \\
\hline \multirow{15}{*}{ 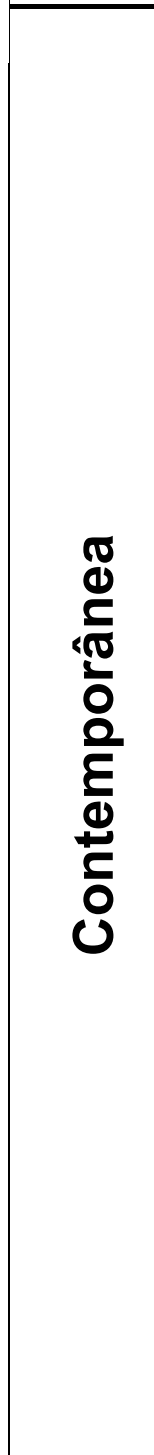 } & O reizinho mandão & Ruth Rocha & Walter Ono & Pioneira & 1978 \\
\hline & O Menino maluquinho & Ziraldo Alves Pinto & Ziraldo Alves Pinto & Melhoramentos & 1980 \\
\hline & Os dez amigos & Ziraldo Alves Pinto & Ziraldo Alves Pinto & Melhoramentos & 1983 \\
\hline & $\begin{array}{l}\text { A história da bolinha } \\
\text { curiosa }\end{array}$ & $\begin{array}{l}\text { Edson Gabriel } \\
\text { Garcia }\end{array}$ & Wilson Martins & Loyola & 1983 \\
\hline & $\begin{array}{l}\text { Se as coisas fossem } \\
\text { mãe }\end{array}$ & Sylvia Orthof & Ana Raquel & Nova fronteira & 1984 \\
\hline & $\begin{array}{l}\text { O lobo e o carneiro no } \\
\text { sonho da menina }\end{array}$ & Marina Colasanti & Marina Colasanti & Cultrix & 1985 \\
\hline & $\begin{array}{l}\text { Menina bonita do laço } \\
\text { de fita }\end{array}$ & Ana Maria Machado & Walter Ono & Ática & 1986 \\
\hline & Farra no formigueiro & $\begin{array}{l}\text { Liliana \& Michele } \\
\text { lacocca }\end{array}$ & $\begin{array}{l}\text { Liliana \& Michele } \\
\text { lacocca }\end{array}$ & Ática & 1986 \\
\hline & $\begin{array}{l}\text { Avental que o vento } \\
\text { leva }\end{array}$ & Ana Maria Machado & $\begin{array}{l}\text { Carlos de Brito e } \\
\text { Wilma Martins }\end{array}$ & Ática & 1987 \\
\hline & O Equilibrista & $\begin{array}{l}\text { Fernanda Lopes de } \\
\text { Almeida }\end{array}$ & $\begin{array}{l}\text { Fernando de Castro } \\
\text { Lopes }\end{array}$ & Ática & 1987 \\
\hline & $\begin{array}{l}\text { O reino das borboletas } \\
\text { brancas }\end{array}$ & $\begin{array}{l}\text { Marli Assunção Go- } \\
\text { mes Pereira }\end{array}$ & $\begin{array}{l}\text { Teruyo Kajiki de Sou- } \\
\text { za }\end{array}$ & Paulinas & 1989 \\
\hline & $\begin{array}{l}\text { O curumim que virou } \\
\text { gigante }\end{array}$ & $\begin{array}{l}\text { Joel Rufino dos San- } \\
\text { tos }\end{array}$ & Lúcia Lacourt & Ática & 1989 \\
\hline & Timóteo, o tatu poeta & Rosana Rios & $\begin{array}{l}\text { Semíramis Nery Pa- } \\
\text { terno }\end{array}$ & Scipione & 1992 \\
\hline & $\begin{array}{l}\text { O Menino que engoliu o } \\
\text { quatro }\end{array}$ & José Carlos Aragão & Ricardo Girotto & Paulinas & 2002 \\
\hline & Que lugar é este? & Maurício Veneza & Maurício Veneza & Paulinas & 2003 \\
\hline
\end{tabular}

Como a pesquisa tem por objetivo subsidiar o trabalho do professor com a L.I. junto aos alunos, evidenciando seu papel formativo junto às crianças, organizamos um roteiro de trabalho, levando em consideração que os professores não recebem, ou recebem pouca orientação em sua formação para trabalhar com a L.I., e não na direção formativa aqui considerada, conforme pesquisas anteriores.

É o seguinte roteiro de trabalho:

- apresentação de característica de cada um dos três períodos de L.I. constituídos nesta pesquisa, considerando: 
- Dados sobre os respectivos autores e a época de produção da obra;

- Título da obra;

- Tema da obra;

- Mensagem - valores veiculados;

- Tipo de discurso - exemplar, ordenativo, argumentativo e interativo;

- Tipo de linguagem - clara, concisa, coloquial;

- Concepção de criança;

- síntese, por período (Clássico, Tradicional, Contemporâneo) de evidências resultantes das análises efetuadas e análise comparativa entre eles.

Em atendimento aos objetivos desta pesquisa, além de disponibilizar alguns possíveis critérios de análise de obras literárias infantis para os professores, consideramos importante apresentar também sugestões de propostas pedagógicas que abram caminhos aos docentes, para viabilizar trabalhos com os alunos, que possibilitem a decodificação de metáforas contidas no texto e a transposição de seus significados para a vida e experiências dos alunos, impulsionando neles o imaginário, a criatividade, oportunizando incursionar, e explorar o fantástico, o absurdo, acionando o imaginário a partir do real. A adequação da proposta ao nível de desenvolvimento das crianças (mais novas ou mais velhas) deixamos a critério do professor. Trata-se de sugestão, apenas para impulsionar o professor a se iniciar na mediação entre L.I. e vida da criança (função formativa da L.I.) e propiciar-Ihe condições para uma escoIha consciente da obra literária adequada ao trabalho de ampliação dos temas escolares que desenvolvem em sua docência.

Organizamos então uma estrutura para elaboração de Propostas Pedagógicas com a L.I. aqui disponibilizadas.

Tal estrutura considera os seguintes itens: 
- apresentação da obra às crianças;

- promover o diálogo sobre a obra, com e entre as crianças, de tal forma a se apropriarem da história, em seu nível de compreensão infantil;

- propor atividade em que os alunos se coloquem no lugar das personagens e indiquem o que fariam no lugar delas;

- conversar com o coletivo da classe sobre as diferentes idéias apresentadas, problematizando-as quando for o caso.

Esta estrutura será nosso instrumento de trabalho na montagem das atividades a que procederemos, a título de sugestão, com a expectativa de que possa servir aos professores na montagem de suas atividades com outras histórias e que também possa completá-la ou mesmo reelaborá-la, a partir de seu saber docente e do conhecimento de seus alunos. 


\section{V - ANÁLISE DOS PERÍODOS DA LITERATURA INFANTIL CONSI- DERADOS E DAS OBRAS SELECIONADAS}

\subsection{CARACTERIZAÇÃO GERAL DOS TRÊS PERÍODOS DA LITERATURA INFANTIL}

Apresentamos a seguir características da L.I. nos contextos Clássico, Tradicional e Contemporâneo, bem como apresentamos dados biográficos de recolhistas da L.I. Clássica e dos autores das histórias infantis brasileira, escolhidas para análise, nesta pesquisa, e características sociais da época de produção de cada uma delas.

\subsubsection{Características da Literatura Clássica Infantil}

Uma das características que identifica um texto como literatura Clássica é sua perenidade: são lidos de geração à geração. E por que permanecem? Porque respondem aos anseios mais profundos do ser humano; abordam questões existenciais, universais, presentes em cada pessoa, de qualquer lugar, em qualquer tempo. São textos que tratam de sentimentos, idéias sempre presente no ser humano que se manifestam em comportamentos, instintivamente, como ciúme, inveja, medo, busca de identidade dentre outros. Cada leitura proporciona um encontro do leitor consigo mesmo. Eis a razão porque desde a criança até o adulto, todos, de uma forma ou de outra se identificam neles. Conforme afirma Professora Nelly ${ }^{96}$, o resgate desses contos faz-se necessário, porque

[...] estamos vivendo em um limiar histórico: entre uma ordem de valores herdada da tradição progressista [...] e uma desordem em cujo bojo uma nova 'ordem' está em gestação... É nesse limiar ou nessa fronteira que se situa o papel formador desses livros antigos. Portanto, longe de serem vistos como algo superado ou mero entretenimento infantil, precisam urgentemente ser redescobertos como fonte de conhecimento de vida.E, nesse sentido, des-

${ }^{96}$ COELHO. 2003, op. cit., p.11. 
cobertos como auxiliares fecundos na formação da mente dos novos, dos 'mutantes' que já estão chegando e precisam ser preparados para atuar no amanhã, que está sendo semeado hoje..

Estudiosos e pesquisadores na área da psicanálise tais como: Bruno BetteIheim, Marie-Louise von Franz, Carl G. Jung, Sigmund Freud, Clarissa Pinkola Estés, Diana Lichtenstein Corso e Mário Corso vêm incentivando a retomada dessa Literatura que a um certo momento da história foi subvalorizada.

Dentre os contos da L.I. Clássica, difundidos no Brasil, encontram-se trabaIhos dos recolhistas, Charles Perrault, Jakob Grimm e Wilhelm Grimm, Hans Christian Andersen, selecionados para objeto de estudo desta pesquisa.

Charles Perrault (1628-1703) nasceu na França no seio de uma família burguesa, estudou nas melhores escolas e formou-se em Direito. Intelectual ativo era membro da "Petite Académie" (equivalente a Academia Francesa de Letras e Belas Artes) e ficou conhecido, no reinado de Luiz IV, pela sua participação na Querela dos Antigos e Modernos, um célebre debate em que o escritor se colocou ao lado dos Modernos, rejeitando a arte da Antigüidade. Esse envolvimento rendeu-lhe dissabores e desafetos, por outro lado, ao se colocar em defesa da Modernidade, dirigiu seu olhar para a arte popular e descobriu na literatura oral os contos que, depois, recolheu e os reuniu no famoso livro Contos da Mamãe Gansa. Perrault era freqüentador assíduo do salão das preciosas onde, sua sobrinha, Mademoiselle Lhéritier comandava os encontros para discutir causas feministas. Foi nessas reuniões que Perrault recolheu os famosos contos e reuniu no livro citado. Para Perrault, a característica essencial dos livros para crianças é a moralidade com inspirações no cristianismo que para ser eficaz deve ser exposta de forma indireta. Conforme Soriano ${ }^{97}$, para Perrault a moral das histórias não podia ser obstinada, mas com traços leves,

${ }^{97}$ SORIANO, Marc. Guide de Littérature pour la jeunesse, Paris: Delagrave, 2002, p. 398. 
quase imperceptíveis e de uma forma geral se concentraria e se concretizaria ao final do conto, mesmo que a criança já tivesse percebido o ensinamento que o conto tinha a transmitir.

O Mestre Gato ou Gato de Botas, Chapeuzinho Vermelho, A Bela Adormecida no Bosque, Barba Azul, Pele de Asno, Cinderela, O pequeno Polegar são alguns dos contos recolhidos pelo escritor.

Jakob Grimm (1785-1863) e Wilhelm Grimm (1786-1859) nasceram na Alemanha. Assim como o pai, eles se formaram em Direito, mas abandonaram a carreira para se dedicaram à Literatura. Eram estudiosos da língua alemã, filólogos, eruditos, historiadores e folcloristas. Tornaram-se famosos pelo trabalho de recolha de um grande número de contos populares. Os irmãos Grimm reconheciam que na memória popular residia a verdadeira expressão da cultura de um povo. Dispostos a registrarem as narrativas orais, percorreram longínquas regiões da Alemanha e encontraram pessoas que eram verdadeiros acervos dessa Literatura como Katherina Wieckmann, camponesa dotada de uma memória genial, cujos contos foram referências para o acervo dos Grimm. Foram nesses encontros que os irmãos pesquisadores encontraram a fantasia, o fantástico e o mítico como temas comuns a vários grupos distantes geograficamente, com hábitos, costumes e língua diferentes. Aliado ao trabalho de resgatar e registrar a cultura popular veio o interesse pela infância, como etapa importante na formação do adulto. Na tradição da época, os contos da oralidade não eram destinados às crianças. Foram os irmãos Grimm que dedicaram as narrativas às crianças por sua temática mágica e maravilhosa, unindo dois universos: o popular e o infantil. A compilação dos contos foi editada em 1812, sob o título Contos da Criança e do Lar, livro traduzido em várias línguas e consagrado 
como um clássico para crianças e jovens, passando a fazer parte como obra-prima da Literatura para crianças e jovens.

Alguns de seus contos mais famosos são: Branca de Neve; João e Maria; Rapunzel; O Ganso de Ouro; O Alfaiate Valente; O Lobo e os sete cabritinhos; Os Sete Corvos; As Aventuras do Irmão Folgazão; Os Músicos de Bremen.

Hans Christian Andersen (1805-1875) escritor dinamarquês dotado de uma inspiração inigualável fez de seus contos parte integrante do universo das crianças. Contos que migraram no tempo e no espaço, foram criados com muita fantasia e humor e são, até hoje, reeditados e representados no teatro, no cinema, na televisão. Patinho feio, O rouxinol e O Imperador da China, A pequena Sereia são lidos e relidos por crianças de todo o mundo. Nasceu em uma família pobre, seu pai era sapateiro, homem de leitura e simpático às idéias revolucionárias francesas, alistouse como soldado no exército de Napoleão, vindo a falecer quando Andersen tinha apenas 9 anos. Sua infância foi difícil e miserável: sua mãe, lavadeira, tinha problemas com bebida e ao contrário do pai era ignorante e supersticiosa; era neto de uma avó sem ternura e uma irmã que se prostituía. Andersen era o único homem dessa família confusa e a ele cabia sustentar e zelar por essas mulheres. Segundo Soriano $^{98}$, essa condição inicial desempenhou um papel importante durante toda a vida do menino: Hans guardou, até o fim de sua vida, o carinho de criança pobre pelas crianças pobres; foi o cenário que rendeu a Andersen uma sensibilidade, às vezes, exagerada e mórbida. Aos 14 anos, ele partiu para Copenhagen. Passou por grandes dificuldades, mas não perdeu de vista o desejo de alcançar a glória, alimentado pela força do amor e o desejo de viver. Quando John Collin resolveu ajudá-lo e the deu condições de estudar, a vida de Andersen começou a mudar. Homem viajante,

${ }^{98}$ SORIANO, op. cit., pp. 45-46. 
Andersen percorreu a Escandinávia, visitou a França, a Itália, chegou à Turquia, viagens que lhe rendaram uma enorme produção Literária: contos, poemas, peças de teatro, relatos de viagens e recolha de contos da literatura oral. Ele escreveu 156 contos. Os primeiros foram contos populares, e a partir de 1843 ele começou a inventar, porém o conteúdo de todos eles aborda os temas com muita emoção: evoca o triunfo do trabalho, rebate a superficialidade das aparências, exalta a verdade e demonstra compaixão pelos fracos e injustiçados.

\subsubsection{Características da Literatura Infantil Tradicional}

Para manter o status quo do sistema social vigente, a L.I. do período Tradicional (séc.XX até década de 70) tinha como objetivo alimentar e conservar os valores sociais, religiosos e familiares por ela consagrados, quer fossem a submissão à autoridade; à disciplina, à ordem, à higiene; a obediência absoluta à autoridade política, religiosa e familiar; preconceitos em relação à pobreza, às etnias (negra,indígena), valorização do ter em detrimento do ser; discriminação do diferente o individualismo. A aparência se sobrepõe à essência. Nelly Novaes Coelho ${ }^{99}$, a respeito de um desses valores, escreve:

Racismo marca a sociedade tradicional, como prolongamento de uma 'instituição' que vem do início dos tempos: a escravização de uma raça pelo outra, resultante das conquistas, sangrentas ou não, de territórios ambicionados por suas riquezas... Nessa imensa luta pelo poder [...], a 'raça branca' foi a vencedora; e com isso instaurou no mundo ocidental um processo de injustiça humana e social que até os nossos tempos não pode ser totalmente estirpada.

${ }^{99}$ COELHO. 2002, op. cit., p.23. 
Nesse contexto, a criança era considerada como um adulto em miniatura, mas, ainda sem direito de opinar e por isso, era considerada um ser inferior. À criança cabia obedecer ao adulto, ser asseada, estudiosa e comportada.

\subsubsection{Características da Literatura Infantil Contemporânea}

A partir dos anos 70, no Brasil, a sociedade passava por grandes mudanças e a L.I. foi marcada pela busca de emancipação do peso tradicional. Tinha o cuidado para que houvesse maior invenção e qualidade literária, ou seja: obras em que o eixo central seria o estímulo ao imaginário do leitor; escritas em estilo conciso e linguagem clara e objetiva que comunicassem o fantástico, o maravilhoso, o poético. Esses valores emergiram naquela década e, ainda hoje, estão assegurados nos textos dos contos contemporâneos porque "Na literatura para crianças ou adultos, o mágico e o absurdo irrompem na rotina cotidiana e fazem desaparecer os limites entre real e imaginário". 100

Com essas características, a L.I. se impõe também por ser questionadora, rompendo com o jogo do poder absoluto, com o preconceito, com o individualismo, com o tabu, deixando para trás valores ultrapassados, respeitando as etnias, valorizando as diferenças, a solidariedade, a partilha, o altruísmo, o ser e não o ter, a essência e não a aparência, dialogando com o mundo que a cerca e interagindo com o processo educacional do leitor, assim como aponta a Professora Nelly ${ }^{101}$ :

[...] tais dados são básicos para o exercício de uma leitura crítica avaliadora dessa literatura nova, que, sem deixar de ser um instrumento de emoção, diversão ou prazer, poderá auxiliar, e muito a tarefa da Educação, no abrir caminho aos que estão chegando, em di-

${ }_{100}^{100}$ COELHO.2002,op.cit.,p.26.

101 COELHO. 2002, op. cit., p.27. 
reção à nova mentalidade a ser conquistada por todos, em breve tempo.

A concepção de criança, nessa nova Literatura, é de um ser em desenvolvimento, em processo de crescimento, em construção de saberes a partir de suas vivências, com direitos a serem respeitados, com necessidades a serem satisfeitas, com liberdade de ser criança e de brincar.

A passagem de uma época literária a outra não significa que a mudança de conceitos verificada na L.I. seja imediatamente seguida por uma prática docente ou mesmo literária totalmente renovada. É um processo lento para assimilar de novas idéias e de traduzi-las em ações e comportamentos. Por isso mesmo, dentro desse novo contexto, é possível encontrar ainda obras com traços característicos da concepção tradicional.

Daí a importância de o professor estar atento à escolha dos textos que serão trabalhados com seus alunos e observar, conforme consideramos anteriormente se:

- o texto contribui para o desenvolvimento humano e do imaginário da criança, enriquecendo-a com novas descobertas;

- se propicia o desenvolvimento da fantasia e criatividade da criança, levando-a a possíveis descobertas;

- se apresenta conseqüências inibidoras a atitudes de coragem e ousadia;

- se se apresenta como instrumento de coerção e submissão, herméticos a outras possibilidades, deixando de provocar no leitor reflexões que o levam à crítica e questionamento.

Ao trabalhar livros ou leituras que se baseiam em valores sejam eles tradicionais, ultrapassados ou modernos, ou que atravessam os tempos, como os clássicos, o melhor procedimento é sempre questioná-los, problematizá-los com os alunos. Levá-los a perceber os aspectos da narrativa que têm sentido hoje, para que 
compreendam os costumes e os valores que se mantêm e/ou se alteram na sociedade com o passar do tempo.

\section{2 ANÁLISE DOS TEXTOS SELECIONADOS}

Tomamos como objeto de pesquisa 34 obras de L.I. (Quadro 1 desta tese). Partimos da consideração de que o contato inicial do professor com obras literárias, tendo em vista a seleção para o trabalho com alunos, exige o discernimento de algumas categorias tais como: o tema, a mensagem, o tipo de discurso, a concepção de criança que sustentam o texto. Através delas é possível identificar o período a que pertence à obra (Clássico, Tradicional ou Contemporâneo) e verificar a adequação ou não, no momento da escolha, aos propósitos do ensino que o professor vai realizar.

Procedemos a análise compreensiva dos textos e explicitamos as categorias criadas para as classificações das obras estudadas.

Construímos, então (com as 34 obras analisadas), um quadro demonstrativo dos resultados de nossa análise a partir desses critérios:

- Tema: levantado a partir da leitura e identificação do eixo temático em torno do qual a história é considerada;

- Mensagem: o recado deixado ao leitor, através do qual é possível distinguir valores trabalhados na obra;

- Tipo de linguagem: servimo-nos das considerações da Professora Nelly sobre a linguagem na L.I;

- Tipo de discurso: utilizamos a partir de características predominantes encontradas no texto, as seguintes categorias: 
- discurso ordenativo: apresenta justificativas para as ordens dadas e não abre espaço de diálogo no texto sobre elas. A experiência do adulto apresenta-se como indiscutível;

- discurso argumentativo: é aquele que já apresenta uma argumentação a respeito das ordens dadas;

- discurso interativo: é aquele que dialoga com o leitor;

-discurso exemplar: os contos exemplares foram trazidos pelos portugueses e eram contados ao redor do fogo, durante o inverno em seu país de origem. Para eles, o exemplo era estímulo para a prática da moral sensível popular, pois era de fácil compreensão. Daí ser considerado discurso exemplar.

- discurso filosófico: é aquele cujo texto incide em reflexões sobre a situação focalizada;

- Concepção de criança: depreende-se de características sócio-culturais da época de produção da obra que permitiram a construção das categorias de análise aqui utilizadas.

Três considerações aqui se fazem necessárias:

a) a análise realizada não pretende ser exaustiva e foi construída a partir das “predominâncias” percebidas/verificadas na obra;

b) não se perdeu de vista a polissemia do texto, em virtude de cada leitura compreender uma construção de significados a partir das experiências de vida do leitor;

c) os elementos acima mencionados, constituem instrumento de análise que não se realizam de maneira "pura" na realidade, admitindo, pois, combinações entre eles. 
A análise realizada com o uso dessas categorias e combinada com a contextualização da obra no espaço/tempo de sua construção, encaminha-nos a uma maior aproximação de significados compreendidos pela obra o que permite:

- a escolha mais adequada aos propósitos do trabalho docente;

- a exploração didática da obra articulada com os objetivos de ensino que se pretende alcançar na atuação docente. 


\subsubsection{Quadros demonstrativos de análise dos textos}

\section{Quadro 2 - Clássicos da Literatura Infantil}

\begin{tabular}{|c|c|c|c|c|c|}
\hline Título da obra & Tema & Mensagem & $\begin{array}{l}\text { Tipo de dis- } \\
\text { curso }\end{array}$ & Tipo de linguagem & Concepção da criança \\
\hline O Pequeno Polegar & $\begin{array}{l}\text { Luta pela sobrevivên- } \\
\text { cia. }\end{array}$ & $\begin{array}{l}\text { O mais forte nem sempre apresenta a } \\
\text { inteligência, sagacidade e esperteza para } \\
\text { solução de um problema. }\end{array}$ & Exemplar & $\begin{array}{l}\text { Narrativa- } \\
\text { Simbólica. }\end{array}$ & $\begin{array}{l}\text { Criança como ser de pen- } \\
\text { samento mágico. }\end{array}$ \\
\hline $\begin{array}{l}\text { O Mestre Gato ou } \\
\text { Gato de Botas }\end{array}$ & $\begin{array}{l}\text { Luta pela sobrevivên- } \\
\text { cia, essência x aparên- } \\
\text { cia. }\end{array}$ & $\begin{array}{l}\text { Em um mundo de opressão, a esperteza, a } \\
\text { sagacidade e a inteligência são indispen- } \\
\text { sáveis para vencer, na luta pela vida. }\end{array}$ & $\begin{array}{l}\text { Exemplar } \\
\text { ordenativo }\end{array}$ & Narrativa-simbólica. & $\begin{array}{l}\text { Criança como ser de pen- } \\
\text { samento mágico. }\end{array}$ \\
\hline A Gata Borralheira & $\begin{array}{l}\text { Estigma da diferença, } \\
\text { essência } \mathrm{x} \text { aparência. }\end{array}$ & $\begin{array}{l}\text { A busca da verdade permite superar a } \\
\text { discriminação familiar e social. }\end{array}$ & Exemplar & $\begin{array}{l}\text { Narrativa-simbólica, } \\
\text { apoiada em imagens } \\
\text { arquetípicas. }\end{array}$ & $\begin{array}{l}\text { Criança como ser de pen- } \\
\text { samento mágico. }\end{array}$ \\
\hline $\begin{array}{l}\text { Chapeuzinho Verme- } \\
\text { lho }\end{array}$ & Essência $\mathrm{x}$ aparência. & Seguir os conselhos maternos. & Exemplar & Narrativa-simbólica. & $\begin{array}{l}\text { Ingenuidade da criança. } \\
\text { Criança como ser de pen- } \\
\text { samento mágico. }\end{array}$ \\
\hline O Patinho Feio & $\begin{array}{l}\text { Estigma da diferença, } \\
\text { essência x aparência. }\end{array}$ & $\begin{array}{l}\text { A descoberta da identidade pela supera- } \\
\text { ção dos preconceitos sociais baseados nas } \\
\text { aparências,pois todos têm o seu valor. }\end{array}$ & Exemplar & Narrativa-simbólica. & $\begin{array}{l}\text { Criança como ser de pen- } \\
\text { samento mágico. }\end{array}$ \\
\hline $\begin{array}{l}\text { O Guardador de } \\
\text { porcos }\end{array}$ & $\begin{array}{l}\text { Estigma da diferença, } \\
\text { essência } \mathrm{x} \text { aparência. }\end{array}$ & $\begin{array}{l}\text { As pessoas valem pelo que são e não pelo } \\
\text { que têm. }\end{array}$ & Exemplar & Narrativa-simbólica, & $\begin{array}{l}\text { Adulto em miniatu- } \\
\text { ra.Criança com responsabi- } \\
\text { lidade do adulto. }\end{array}$ \\
\hline
\end{tabular}


Quadro 3 - Período da Literatura Infantil tradicional brasileira

\begin{tabular}{|c|c|c|c|c|c|}
\hline Título da obra & Tema & Mensagem & Tipo de discurso & Tipo de linguagem & Concepção da criança \\
\hline A Galina Ruiva & $\begin{array}{l}\text { Apologia do traba- } \\
\text { lho }\end{array}$ & Quem não trabalha, não come. & $\begin{array}{l}\text { Exemplar, } \\
\text { ordenativo }\end{array}$ & $\begin{array}{l}\text { Concisa, clara, } \\
\text { objetiva. }\end{array}$ & $\begin{array}{l}\text { Deve ser disciplinada } \\
\text { com austeridade. }\end{array}$ \\
\hline Paulina pega-fogo & Obediência & $\begin{array}{l}\text { Quem não obedece, sofre as conse- } \\
\text { qüências. }\end{array}$ & $\begin{array}{l}\text { Exemplar, } \\
\text { ordenativo }\end{array}$ & $\begin{array}{l}\text { Objetiva, utilitária, } \\
\text { clara, vocabulário } \\
\text { fácil. }\end{array}$ & $\begin{array}{l}\text { Deve ser disciplinada } \\
\text { com austeridade, inclusi- } \\
\text { ve com a carga de res- } \\
\text { ponsabilidade que recai } \\
\text { sobre o adulto. }\end{array}$ \\
\hline Tonico balança-e-cai & Obediência & $\begin{array}{l}\text { Quem não obedece sofre as conse- } \\
\text { qüências. }\end{array}$ & $\begin{array}{l}\text { Exemplar, } \\
\text { ordenativo. }\end{array}$ & $\begin{array}{l}\text { Objetiva, clara, } \\
\text { utilitária. }\end{array}$ & $\begin{array}{l}\text { Deve ser disciplinada } \\
\text { com austeridade. }\end{array}$ \\
\hline $\begin{array}{l}\text { O Porquinho Dormi- } \\
\text { nhoco }\end{array}$ & $\begin{array}{l}\text { Censura à preguiça e } \\
\text { a ociosidade. }\end{array}$ & Condenação à preguiça. & Exemplar & $\begin{array}{l}\text { Infantilizada } * \text {, de fácil } \\
\text { compreensão, presença } \\
\text { de diálogos. }\end{array}$ & Adulto em miniatura. \\
\hline O menino mal criado & Obediência aos pais & $\begin{array}{l}\text { Quem não sabe se comportar, não } \\
\text { merece ser respeitado. }\end{array}$ & $\begin{array}{l}\text { Exemplar, } \\
\text { ordenativo }\end{array}$ & $\begin{array}{l}\text { Objetiva, clara, } \\
\text { utilitária. }\end{array}$ & $\begin{array}{l}\text { Deve ser disciplinada } \\
\text { com austeridade. }\end{array}$ \\
\hline A carteira perdida & $\begin{array}{l}\text { A honestidade é um } \\
\text { dever. }\end{array}$ & $\begin{array}{l}\text { O cumprimento do dever não deve } \\
\text { ser motivo de vaidade. }\end{array}$ & Exemplar & Direta, clara, utilitária. & $\begin{array}{l}\text { Deve ser disciplinada } \\
\text { com austeridade. }\end{array}$ \\
\hline $\begin{array}{l}\text { Bitu, o carneirinho } \\
\text { sujo }\end{array}$ & $\begin{array}{l}\text { Obediência e higie- } \\
\text { ne. }\end{array}$ & $\begin{array}{l}\text { Quem não escuta os pais, recebe } \\
\text { castigo. }\end{array}$ & $\begin{array}{l}\text { Exemplar } \\
\text { ordenativo }\end{array}$ & $\begin{array}{l}\text { Infantilizada, presença } \\
\text { de diálogos, clara. }\end{array}$ & $\begin{array}{l}\text { Deve ser disciplinada } \\
\text { com austeridade. }\end{array}$ \\
\hline O Burrinho Verde & $\begin{array}{l}\text { Preconceito contra o } \\
\text { diferente. }\end{array}$ & $\begin{array}{l}\text { Todos têm o seu valor e espaço na } \\
\text { sociedade. Valorização da paciên- } \\
\text { cia, descoberta da identidade. }\end{array}$ & Argumentativo, & $\begin{array}{l}\text { Infantilizada, fácil } \\
\text { compreensão. }\end{array}$ & Crianças padronizada. \\
\hline O galo de casa & $\begin{array}{l}\text { Denuncia a ignorân- } \\
\text { cia, acerca das ver- } \\
\text { dadeiras causas das } \\
\text { coisas. }\end{array}$ & $\begin{array}{l}\text { “Quem não sabe o pouco suportar, } \\
\text { um mal maior, há de então encon- } \\
\text { trar". }\end{array}$ & Ordenativo & Redutiva, formal. & Adulto em miniatura. \\
\hline
\end{tabular}




\begin{tabular}{|l|l|l|l|l|l|}
\hline \multicolumn{1}{|c|}{ Título da obra } & \multicolumn{1}{|c|}{ Tema } & \multicolumn{1}{|c|}{ Mensagem } & Tipo de discurso & Tipo de linguagem & \multicolumn{1}{|c|}{ Concepção da criança } \\
\hline Nhá Dita Contou & Preconceito & A intolerância com a diferença.. & Argumentativo & $\begin{array}{l}\text { De fácil compreensão, } \\
\text { clara, objetiva. }\end{array}$ & $\begin{array}{l}\text { Comportada ordenada, } \\
\text { limpa e obediente. }\end{array}$ \\
\hline $\begin{array}{l}\text { Chiquinho o mexe- } \\
\text { mexe }\end{array}$ & $\begin{array}{l}\text { O bom comporta- } \\
\text { mento. }\end{array}$ & A curiosidade pode matar. & Ordenativo & $\begin{array}{l}\text { Redutiva, impessoal, } \\
\text { utilitária. }\end{array}$ & $\begin{array}{l}\text { Deve ser disciplinada } \\
\text { com austeridade. }\end{array}$ \\
\hline Lição merecida & $\begin{array}{l}\text { Diferenças individu- } \\
\text { ais. }\end{array}$ & A condenação do desperdício. & Exemplar & $\begin{array}{l}\text { Redutiva, utilitária, } \\
\text { formal. }\end{array}$ & $\begin{array}{l}\text { Deve ser disciplinada } \\
\text { com austeridade. }\end{array}$ \\
\hline
\end{tabular}

* Observação: linguagem infantilizada é a linguagem concebida pelo adulto ( predominância de -inhos). 


\section{Quadro 4 - Período contemporâneo da Literatura Infantil brasileira}

\begin{tabular}{|c|c|c|c|c|c|}
\hline Título da obra & Tema & Mensagem & Tipo de discurso & Tipo de linguagem & Concepção da criança \\
\hline $\begin{array}{l}\text { O reizinho man- } \\
\text { dão }\end{array}$ & $\begin{array}{l}\text { Crítica ao poder } \\
\text { autoritário, exalta- } \\
\text { ção à liberdade de } \\
\text { expressão. }\end{array}$ & $\begin{array}{l}\text { Cala boca já morreu, quem } \\
\text { manda na minha boca sou } \\
\text { eu. }\end{array}$ & $\begin{array}{l}\text { Argumentati- } \\
\text { vo,filosófico }\end{array}$ & $\begin{array}{l}\text { Clara, concisa, } \\
\text { espontânea. }\end{array}$ & $\begin{array}{l}\text { Ser em desenvolvimen- } \\
\text { to,criativo, com direito à } \\
\text { voz e demais direitos } \\
\text { preservados. }\end{array}$ \\
\hline O equilibrista & $\begin{array}{l}\text { Exaltação àcriati- } \\
\text { vidade e à inven- } \\
\text { ção. }\end{array}$ & $\begin{array}{l}\text { Construir a vida partir das } \\
\text { condições encontradas. }\end{array}$ & $\begin{array}{l}\text { Argumentativo, } \\
\text { interativo, filosófico }\end{array}$ & $\begin{array}{l}\text { Metafórica, } \\
\text { acessível, coloquial. }\end{array}$ & $\begin{array}{l}\text { Ser em desenvolvimento, } \\
\text { criativo, com direito à voz } \\
\text { e demais direitos preser- } \\
\text { vados. }\end{array}$ \\
\hline $\begin{array}{l}\text { O curumim que } \\
\text { virou gigante }\end{array}$ & $\begin{array}{l}\text { Lenda do Morro do } \\
\text { Corcovado. }\end{array}$ & A rigidez do desejo. & Exemplar & $\begin{array}{l}\text { Coloquial, clara, uso } \\
\text { constante de diálogo } \\
\text { e presença de pala- } \\
\text { vras } \\
\text { de origem indígena. }\end{array}$ & $\begin{array}{l}\text { Admissão de diferentes } \\
\text { concepções de criança em } \\
\text { desenvolvimento. }\end{array}$ \\
\hline Os dez amigos & $\begin{array}{l}\text { A importância da } \\
\text { união. }\end{array}$ & A união faz a força. & Interativo & $\begin{array}{l}\text { Clara, concisa, diver- } \\
\text { tida e poética. }\end{array}$ & $\begin{array}{l}\text { Ser em desenvolvimen- } \\
\text { to,criativo, com direito à } \\
\text { voz e demais direitos } \\
\text { preservados. }\end{array}$ \\
\hline $\begin{array}{l}\text { A história da } \\
\text { bolinha curiosa }\end{array}$ & $\begin{array}{l}\text { Valorização da } \\
\text { criatividade e de } \\
\text { novas experiências. }\end{array}$ & $\begin{array}{l}\text { A vida pode ser mais inte- } \\
\text { ressante se abandonarmos o } \\
\text { comodismo. } \\
\text { Exaltação da conduta inves- } \\
\text { tigativa. }\end{array}$ & Argumentativo & Concisa & $\begin{array}{l}\text { Ser em desenvolvimento, } \\
\text { criativo, com direito à voz } \\
\text { e demais direitos preser- } \\
\text { vados. }\end{array}$ \\
\hline $\begin{array}{l}\text { Se as coisas fos- } \\
\text { sem mãe }\end{array}$ & $\begin{array}{l}\text { O amor materno } \\
\text { transforma as rela- } \\
\text { ções. }\end{array}$ & Exaltação do amor de mãe. & Exemplar & Poética, humorística & $\begin{array}{l}\text { Ser em desenvolvimento } \\
\text { com direito à voz e demais } \\
\text { direitos preservados. }\end{array}$ \\
\hline $\begin{array}{l}\text { Farra no formi- } \\
\text { gueiro }\end{array}$ & $\begin{array}{l}\text { Relação trabalho } \\
\text { e prazer. }\end{array}$ & $\begin{array}{l}\text { Trabalho e prazer não são } \\
\text { incompatíveis. }\end{array}$ & Argumentativo & $\begin{array}{l}\text { Humorística, } \\
\text { clara, inventiva. }\end{array}$ & $\begin{array}{l}\text { Ser em desenvolvimento } \\
\text { com direito à voz e demais } \\
\text { direitos preservados. }\end{array}$ \\
\hline $\begin{array}{l}\text { O reino das bor- } \\
\text { boletas brancas }\end{array}$ & $\begin{array}{l}\text { Desafiar a norma } \\
\text { estabelecida. }\end{array}$ & $\begin{array}{l}\text { Viver novas experiências } \\
\text { nos enriquece. }\end{array}$ & Argumentativo & Formal, infantilizada & $\begin{array}{l}\text { Ser em desenvolvimento } \\
\text { com direito à voz e de- } \\
\text { mais direitos preservados. }\end{array}$ \\
\hline
\end{tabular}




\begin{tabular}{|c|c|c|c|c|c|}
\hline Título da obra & Tema & Mensagem & Tipo de discurso & Tipo de linguagem & Concepção da criança \\
\hline $\begin{array}{l}\text { Timóteo, o tatu } \\
\text { poeta }\end{array}$ & $\begin{array}{l}\text { Desafiar o poder } \\
\text { dominante e autori- } \\
\text { tário. }\end{array}$ & $\begin{array}{l}\text { A força da evolução da vida } \\
\text { é maior e não há poder que } \\
\text { a impeça. }\end{array}$ & Interativo & $\begin{array}{l}\text { Objetiva, clara, poé- } \\
\text { tica. }\end{array}$ & $\begin{array}{l}\text { Ser em desenvolvimento } \\
\text { com direito à voz e de- } \\
\text { mais direitos preservados. }\end{array}$ \\
\hline $\begin{array}{l}\text { O lobo e o carnei- } \\
\text { ro no sonho da } \\
\text { menina }\end{array}$ & Dominar o medo. & $\begin{array}{l}\text { Devemos reagir quando } \\
\text { somos intimidados. }\end{array}$ & $\begin{array}{l}\text { Argumentativo, filosó- } \\
\text { fico }\end{array}$ & $\begin{array}{l}\text { Objetiva,clara poéti- } \\
\text { ca. }\end{array}$ & $\begin{array}{l}\text { Ser em desenvolvimento } \\
\text { com direito à voz e de- } \\
\text { mais direitos preservados. }\end{array}$ \\
\hline $\begin{array}{l}\text { Avental que o } \\
\text { vento leva }\end{array}$ & $\begin{array}{l}\text { Liberdade para } \\
\text { brincar. }\end{array}$ & $\begin{array}{l}\text { Às vezes o que procuramos } \\
\text { está bem mais próximo do } \\
\text { que imaginávamos. }\end{array}$ & Interativo & Clara, espontânea & $\begin{array}{l}\text { Ser em desenvolvimento } \\
\text { com direito à voz e de- } \\
\text { mais direitos preservados. }\end{array}$ \\
\hline $\begin{array}{l}\text { Menina bonita do } \\
\text { laço de fita }\end{array}$ & $\begin{array}{l}\text { Valorização da } \\
\text { pluralidade étnica. }\end{array}$ & $\begin{array}{l}\text { Somos todos iguais, inde- } \\
\text { pendente da cor. } \\
\text { Superação do preconceito, } \\
\text { auto-aceitação. }\end{array}$ & Interativo & Poética, lúdica, clara & $\begin{array}{l}\text { Ser em desenvolvimento } \\
\text { com direito à voz e de- } \\
\text { mais direitos preservados. }\end{array}$ \\
\hline $\begin{array}{l}\text { O Menino Malu- } \\
\text { quinho }\end{array}$ & $\begin{array}{l}\text { Valorização da } \\
\text { curiosidade infan- } \\
\text { til. }\end{array}$ & $\begin{array}{l}\text { Exaltação ao imaginário, } \\
\text { à exploração infantil da } \\
\text { realidade. }\end{array}$ & Interativo & $\begin{array}{l}\text { Poética, clara, } \\
\text { inventiva, humorísti- } \\
\text { ca }\end{array}$ & $\begin{array}{l}\text { Ser em desenvolvimento } \\
\text { com direito à voz e de- } \\
\text { mais direitos preservados. }\end{array}$ \\
\hline $\begin{array}{l}\text { O menino que } \\
\text { engoliu o quatro }\end{array}$ & $\begin{array}{l}\text { Exaltação ao ima- } \\
\text { ginário infantil. }\end{array}$ & $\begin{array}{l}\text { Mesmo adultos, podemos } \\
\text { resgatar nosso lado criança. }\end{array}$ & Interativo & $\begin{array}{l}\text { Poética, metafórica, } \\
\text { experimental, tom } \\
\text { dexpectativa. }\end{array}$ & $\begin{array}{l}\text { Ser em desenvolvimento } \\
\text { com direito à voz e de- } \\
\text { mais direitos preservados. }\end{array}$ \\
\hline Que lugar é este? & $\begin{array}{l}\text { Como lidar com o } \\
\text { desconhecido. }\end{array}$ & $\begin{array}{l}\text { Somos livres e capazes para } \\
\text { enfrentar os desafios na } \\
\text { vida. }\end{array}$ & Filosófico, interativo & Clara, concisa & $\begin{array}{l}\text { Ser em desenvolvimento } \\
\text { com direito à voz e de- } \\
\text { mais direitos preservados. }\end{array}$ \\
\hline
\end{tabular}




\subsubsection{Complementando a caracterização dos períodos}

Os quadros 2,3 e 4 permitem completar e comparar características dos três períodos da L.I., considerados neste trabalho. Evidenciam diferenças significativas entre as concepções de criança que suportam cada período, bem como os valores da época trabalhados em cada um deles.

As obras Clássicas da L.I. trabalham com temas que constituem os arquétipos da humanidade, ligados aos ardis da luta pela sobrevivência, extremamente difíceis de serem superadas. Produzidas em tempo de absolutismos inquestionáveis, apóiam-se na concepção de um mundo estável, de um status quo perene. Encaminham sempre soluções individualistas em que a criatividade humana se limita à esperteza e à sagacidade de cada um. Têm como referência a criança dotada de pensamento mágico, cuja esperteza e sagacidade precisam ser despertadas para que, individualmente, consiga ver e explorar brechas de sobrevivência, em uma ordem social opressiva e castradora. Nos contos A Gata Borralheira, O Pequeno Polegar, O Gato de Botas, através de uma sedutora exploração do pensamento mágico infantil é feito o encaminhamento do pequeno leitor pelas árduas trilhas da luta pela sobrevivência, pois através do poder mágico a criança consegue, sozinha, superar as provações impostas pelo opositor e vencer na vida.

Já a comparação entre as obras de L.I. Tradicional e L.I. Contemporânea permite explicitar diferenças marcantes entre as possibilidades formativas oferecidas em textos de um e outro período.

Ocorre uma mudança significativa em relação aos temas focalizados nos dois períodos, bem como em relação à L.I. Clássica.

Enquanto na L.I. Clássica, os temas focalizam questões humanas que atravessam os tempos, os temas na L.I. Tradicional e na L.I. Contemporânea se ligam a 
questões presentes da conjuntura sócio-político-econômica de cada um dos períodos de produção.

Os textos da L.I.Tradicional estão centrados na reprodução da ordem vigente e ditam ordens e padrões de comportamento ao pequeno leitor.

Em Paulina pega-fogo, o castigo para a desobediência é trágico: a menina morre. Desfecho elevado à conseqüência irreversível da punição (a morte), para mostrar o perigo que é brincar com fogo. É assustador, provoca medo e angústia na criança.

A conseqüência da desobediência do menino em Tonico balança-e-cai é a queda da cadeira, levando para o chão tudo que havia sobre a mesa. Embora o desfecho seja menos dramático que o de Paulina, o conto, também, reforça o castigo para crianças que não atendem as orientações dos adultos.

Os textos do período Contemporâneo são questionadores da ordem estabelecida, sem perder o humor, a ludicidade e a poesia da arte literária, sempre incursionando pelo mundo da fantasia infantil.

Assim é em O reizinho mandão, em que a autora questiona o autoritarismo do rei que de tão autoritário acaba solitário. Os súditos daquele reino já não mais aceitam tal postura e reagem com o silêncio e o desprezo, a ponto de o rei ser forçado a mudar de atitude. E quem promove diretamente a mudança é uma criança, ao dizer para o rei: "Cala a boca já morreu! Quem manda na minha boca sou eu!", o que retrata simbolicamente a nova concepção de criança enquanto ser criativo, em desenvolvimento, sensível, capaz de pensar e de agir de forma conseqüente.

Em O Equilibrista, o pequeno leitor é desafiado a pensar sobre o inusitado das situações da vida do personagem, a questionar-se e, sobretudo a divertir-se. 
A criança como ser em desenvolvimento, espontânea e criativa a quem Lobato deu vida na Literatura é que está presente nas obras desse período.

A capacidade imaginativa da criança capaz de dar vida aos objetos, fruto de sua fantasia é legitimada na Literatura Contemporânea.

Dentro dessa mesma proposta, citamos O Menino que engoliu o quatro, em que o cotidiano da criança está totalmente absorvido pela sua capacidade imaginativa.

Se as coisas fossem mãe é um texto carregado de humor e ternura, em que a figura da mãe é de carinho, aconchego, alegria, sabor de mel, calor, compreensão, doçura, festa, riso, abraço.

Conteúdo com mensagem similar ocorreu em Timóteo, o tatu poeta que resolveu sair da toca e observar a natureza. Respirou novos ares, venceu o medo e com isso descobriu o novo, que se consubstanciou na poesia. A trama de Timóteo, o tatu poeta desenvolve-se no rompimento do equilíbrio dentro da toca dos tatus, onde era proibido adotar novos comportamentos e fazer outras escolhas que não aquelas do padrão determinado pelo Conselho-governante. O tatu enfeitiçado pela poesia foi a chave para a transformação da toca. Poetar era o ar que o jovem Timóteo respirava, que mantinha sua alma viva rompendo dessa forma com uma concepção de que poetar é sinônimo de ócio.

Em O lobo e o carneiro no sonho da menina, o medo é exorcizado através do sonho. Nele é permitido inverter a ordem das coisas, quebrar a visão maniqueísta de que o lobo é sempre mau e o carneiro é sempre bom. Há espaço para a fantasia, para a imaginação, para a liberdade, de até mostrar os dentes.

Liberdade de ser criança, de se sujar, de brincar na terra, na lama, com tinta, com água, com o que quisesse é o tema de Avental que o vento leva. Corina cria, 
recria, pinta e se lambuza, com liberdade, sem censura. É respeitada como criança que precisa de espaço para suas descobertas. Ao contrário de Bitu, o carneirinho sujo que não podia se sujar nem ousar fazer novas experiências: "Sejam bem comportados! Não manchem esse lindo pêlozinho tão branco"

Contrapondo-se a posicionamentos individualistas e infantilizados, para o que nos alerta a obra de Lobato, a L.I. Clássica volta-se para a importância do coletivo e para a capacidade da criança, o que se pode constatar em A história da bolinha curiosa e Farra no Formigueiro. Essa obra é também elucidativa da tendência de reelaboração de textos, por se tratar da desconstrução da fábula de La Fontaine, $A$ cigarra e a formiga.

O espírito nacionalista, defendido por Lobato, abre espaço à presença do folclore e das lendas indígenas nos textos da contemporaneidade como podemos observar em O curumim que virou gigante que narra a lenda do Morro do Corcovado, no Rio de Janeiro, para explicar a forma da montanha. A partir da mensagem: a rigidez de conduta petrifica o ser humano, está exposta a contemporaneidade, expõe a complexidade do real, desdobrado em diferentes culturas e visões de mundo, com raízes na sociedade indígena.

Apesar das aberturas constatadas, a sociedade brasileira ainda não soterrou todas as formas de preconceito racial e sabe-se que, de uma maneira consciente ou não, há intolerância e desrespeito, às vezes de forma velada, quanto aos negros. Em tempos passados, o problema do preconceito nem sequer era discutido em público; hoje, essa discussão já ocupa espaço nos meios de comunicação e, paulatinamente, os órgãos públicos vêm aprovando leis que punem essa conduta injusta.

Em Menina bonita do laço de fita, a questão do preconceito é abordada de maneira tranqüila. A menina é negra, feliz, inteligente, esperta, criativa e bonita. É 
invejada pelo coelho branco que, a todo custo, quer ser negro como ela. Esse texto se contrapõe ao do Negrinho, em que a negritude, no contexto tradicional, era tida como "um castigo de Deus". Ser negro era ser infeliz; o negro se ressentia em ser negro, queria ser branco como Ditinho em Nhá Dita contou.

Abre-alas que vou passar! Se antes a travessura era rotulada como mau costume ou incorrigível, como em Chiquinho o mexe-mexe, agora a criança é apresentada como um ser que tem liberdade para ser criança e se expressar como em 0 Menino maluquinho. A peraltice não só ganha espaço como também é compreendida pelo adulto, que carinhosamente o batiza o personagem de maluquinho. Maluquinho era feliz, inteligente, e como toda criança a fantasia e a imaginação ganham asas.

Que lugar é este? exemplifica uma outra tendência na produção literária contemporânea: como lidar com o desconhecido. Primeiramente, o coelho buscou conhecer o espaço, organizou as informações, elaborou estratégias, reuniu recursos e partiu para a ação até atingir seu objetivo: sair de onde estava. Trata-se de uma situação que tem correspondência com 'estar vivo' e pronto para lidar com adversidades. Cria expectativa no leitor, prendendo a atenção, provocando o riso e a reflexão.

O fato de vivermos em um contexto social e histórico, cujos modelos de comportamento são opostos ao tradicional, com outros valores, outra visão de mundo, não significa que as pessoas mudem como em um passe de mágica. Há de se respeitar a individualidade. A assimilação de novos valores é um processo lento. Por isso encontramos características da sociedade tradicional mescladas com as da contemporânea, na L.I. deste período. Há textos em que o autor apresenta uma proposta inovadora, mas ainda está apegado a formas e estruturas narrativas do estilo tradicional como, por exemplo, o uso excessivo de diminutivos, linguagem formal e sem 
explorar o espaço do imaginário do leitor. É o caso de O reino das borboletas brancas.

O desfecho em A história da bolinha curiosa, não provoca expectativas no leitor embora seja um texto interessante, atraente, criativo e aberto para o imaginário. . Não o provoca em uma pergunta, não o convida a continuar, com a personagem, vencendo outros desafios.

Na L.I. Contemporânea, as ilustrações estão mais presentes, são riquíssimas e dialogam com o verbal, oferecendo a possibilidade de várias leituras, pois a relação palavra-imagem é complementar e interativa. Os textos são criados no cruzamento das linguagens verbal e imagética, em que as imagens complementam a fantasia e, ao mesmo tempo, incentivam a exploração do real.

Os ilustradores aperfeiçoam, cada vez mais, seu trabalho com novas técnicas, novos conhecimentos. Verdadeiros pesquisadores em busca do melhor, pois a criança reconhece e exige um livro com alta qualidade, tanto literária como editorial.

\subsubsection{Proposta Pedagógica}

Esta análise não esgota ainda os conhecimentos que o professor necessita na elaboração do trabalho com a L.I., no sentido aqui preconizado.

Serão as Propostas Pedagógicas organizadas pelo docente que permitirão a mediação necessária para que os alunos incorporem as mensagens da L.I. ao seu imaginário e as articulem com suas experiências de vida, re-elaborando os seus conhecimentos.

Para tanto apresentaremos Propostas Pedagógicas cuja estrutura resulta de experiências de ensino, metodologicamente constatadas nos 590 cursos de formação continuada sobre L.I. que ministramos pelo Brasil, desde 1987. Consideramos desnecessário a apresentação de 34 propostas correspondentes ao trabalho didáti- 
co com cada obra aqui focalizada; seja porque a estrutura das Propostas Pedagógi-

cas se encontra explicitada no capítulo IV (Metodologia de pesquisa), seja porque a

essência dessa estrutura encontra suporte na fundamentação teórica, aqui apresen-

tada. Desta forma reduzimos a extensão deste trabalho e a monotonia em que se incorreria, uma vez que, a estrutura que serve de suporte às Propostas Pedagógicas é a mesma para todas as sugestões apresentadas.

Escolhemos então para a apresentação das referidas propostas (9) histórias de exploração das propriedades formativas do texto que, ao nosso ver, apresentam nitidamente as características do período em que se encontram aqui classificadas. Disponibilizamos no início de cada proposta as histórias originais, na íntegra. No Anexo encontram-se os textos originais das demais histórias aqui analisados.

\section{O PEQUENO POLEGAR}

Charles Perrault

Era uma vez um lenhador e uma lenhadora que tinham sete filhos, todos do sexo masculino. O primogênito tinha apenas dez anos e o caçula não passava dos sete. É possível que haja surpresa, pelo fato de o lenhador ter tantos filhos em tão pouco tempo; mas ocorre que sua mulher trabalhava depressa e não dava a luz menos que dois ao mesmo tempo. Eles eram muito pobres, e seus sete filhos os incomodavam muito, visto que nenhum deles estava ainda em condições de ganhar a vida. O que desconsolava mais era que o mais novo era muito delicado e nada dizia; tomavam por parvoíce o que era uma marca de bondade de seu espírito. Ele era muito pequeno e, quando veio ao mundo, não era maior do que o dedo polegar, o que fez que fosse chamado de Pequeno Polegar. O pobre menino era alvo dos gracejos da casa, sempre sendo criticado em sua conduta. Entretanto, era o mais esperto e também o mais prudente dos irmãos, e se falava pouco, escutava bastante. Veio um ano muito difícil, e a penúria foi tão grande que aquelas pobres pessoas resolveram desfazer-se dos filhos. Um dia em que estes se achavam deitados e que o lenhador estava junto ao fogo ao lado da mulher, disse-lhe ele, com o coração premido de dor: bem vês que não podemos alimentar nossos filhos; eu não poderia vê-los morrer de fome diante de meus olhos e tomei a decisão de levá-los amanhã ao bosque para se perderem, o que será fácil, pois enquanto estiverem se divertindo enfaixando lenha, nós só teremos de escapar sem que nos vejam.

Ah! - exclamou a lenhadora - Poderias de fato levar teus filhos para se perderem? Em vão o marido Ihe descrevia sua grande pobreza; ela não podia concordar com isso; era pobre, mas era sua mãe. Contudo, tendo considerado a grande dor que seria para eles vê-los morrer de fome, consentiu com o plano e foi deitar-se chorando. O Pequeno Polegar ouviu tudo o que os pais disseram, pois, tendo escutado de sua cama que falavam de negócios, se levantara silenciosamente e deslizara para sob o banco do pai para escutá-los sem ser visto. Ele foi deitar-se e não dormiu durante o resto da noite, imaginando o que tinha de fazer. Levantou-se bem cedo e foi à beira de um regato, onde encheu os bolsos de pequenas pedras brancas, voltando em seguida para casa. Partiram e o Pequeno Polegar nada contou aos irmãos de tudo o que sabia. Dirigiram-se a uma floresta muito espessa, na qual não era possível ver ninguém a dez passos de distância. O lenhador começou a cortar lenha e os filhos a apanhar os raminhos para fazer feixes. O pai e a mãe, vendo-os ocupados a trabalhar, se afastaram deles imperceptivelmente e depois fugiram rapidamente para um pequeno atalho. Quando se viram a sós, as crianças começaram a gritar e a chorar com todas as forças. O Pequeno Polegar 
deixou-os gritar, sabendo com clareza por onde voltaria a casa, pois, ao caminhar, marcara o caminho com as pedras brancas que tinha nos bolsos. Ele lhes disse então: Não temais, meus irmãos; meu pai e minha mãe nos deixaram aqui, mas eu vos reconduzirei ao lar; só tendes de me seguir. Eles o seguiram e o Pequeno Polegar os levou até sua casa pelo mesmo caminho que tinha percorrido até a floresta. Não ousaram entrar de imediato, mas se encostaram à porta para escutar o que diziam o pai e a mãe.

No momento em que o lenhador e a lenhadora chegaram a casa, o senhor da aldeia lhes enviou dez escudos que lhes devia havia muito tempo e que eles não esperavam mais receber. Isso os animou, pois os pobres morriam de fome. O lenhador enviou imediatamente a mulher ao açougue. Como havia muito tempo que não comia, ela comprou três vezes mais carne do que a necessária para a ceia de duas pessoas. Quando se saciaram, a lenhadora disse: Ai de mim! Onde estão agora nossos pobres filhos? Eles fariam bom proveito do que nos sobrou. Mas, Guilherme, foste tu que quiseste fazê-los se perder; eu bem disse que nos arrependeríamos desse ato. Que farão agora naquela floresta? Ai de mim! Meu Deus, os lobos já devem tê-los comido! És bem desumano de ter feito teus filhos se perderem dessa maneira. O lenhador acabou por se impacientar, pois ela repetiu mais de vinte vezes que eles se arrependeriam de tê-lo feito e que ela bem dissera ao marido. Ele ameaçou bater-lhe se ela não se calasse. Não que o lenhador não estivesse talvez ainda mais contrariado que a mulher, mas é que ela o importunava muito, possuindo ele o temperamento de muitas outras pessoas, que amam muito as mulheres que dão boas opiniões, mas que acham muito impertinentes as que nunca deixam de dar boas opiniões. A lenhadora estava banhada em lágrimas. Ai de mim! Onde estarão agora meus filhos, meus pobres filhos? Ela o disse uma vez tão alto que os meninos que estavam à porta, tendo-a ouvido, começaram a gritar todos juntos: Estamos aqui, estamos aqui. Ela correu com toda pressa para abrir-Ihes a porta e disse-lhes, abraçando-os: Como estou feliz de vos rever, meus filhos queridos! Estais bem cansados e tendes muita fome; e tu, Pierrot, como estás enlameado, vem que vou te limpar. Pierrot era seu primogênito, o filho que ela amava mais que a todos, porque era um pouco arruivado e ela era um pouco ruiva. Eles se sentaram à mesa e comeram com um apetite que dava gosto ao pai e à mãe, a quem contaram o medo que tinham tido na floresta, falando quase sempre todos juntos. Aquelas boas pessoas estavam encantadas de rever os filhos, tê-los consigo, e tal alegria durou enquanto duraram os dez escudos. Mas quando o dinheiro foi gasto, recaíram no primitivo desgosto e resolveram levá-los a perderem-se outra vez e, para ter certeza do êxito dessa iniciativa, conduzi-los bem mais longe do que na primeira vez. Eles só puderam falar do assunto secretamente para que não fossem ouvidos pelo Pequeno Polegar, que voltou a esgueirar-se tal como já o fizera; mas, embora se tenha levantado bem cedo para apanhar pedrinhas, ele conseguiu fazê-lo, pois encontrou a porta da casa fechada com duas voltas de chave. O Pequeno Polegar não sabia o que fazer; mas, tendo a lenhadora dado um deles um pedaço de pão como café da manhã, pensou que poderia se valer de seu pão em lugar das pedrinhas, jogando-o às migalhas ao longo dos caminhos por onde passassem; por conseguinte, guardou o pão no bolso. O pai e a mãe os levaram ao lugar mais fechado e mais escuro da floresta e, quando lá estavam, tomaram um atalho e deixaram-nos lá. O Pequeno Polegar não se preocupou com isso, porque julgava encontrar facilmente o caminho graças a seu pão, que esmigalhara por todo o trajeto; mas ficou muito surpreso quando não pôde encontrar uma única migalha; tinham vindo pássaros que as tinham comido. Ficaram então muito aflitos, pois, quanto mais andavam, tanto mais se perdiam e se entranhavam na floresta. Veio a noite e começou a soprar um forte vento que provocava neles terríveis temores. Eles julgavam não ouvir de todos os lados senão uivos de lobos que deles se aproximavam para comê-los. Quase não ousava falar entre si nem virar a cabeça. Sobreveio uma grande chuva que os traspassou até os ossos; eles escorregaram a cada passo e caíram no lodo, de onde se erguiam inteiramente enlameados, não sabendo o que fazer de suas mãos. O Pequeno Polegar subiu ao alto de uma árvore para ver se descobria algo; tendo olhado para todos os lados, viu um pequeno clarão como de uma candeia, mas que se encontrava bem longe, para além da floresta. Ele desceu da árvore e, quando chegou ao chão, não viu mais nada; isso o desolou. Entretanto, tendo andado algum tempo com os irmãos na direção em que vira a luz, ele voltou a vê-la ao sair do bosque. Os meninos chegaram enfim à casa em que estava aquela candeia, não sem passar por muitos sustos, dado que com freqüência a perdiam de vista, o que lhes acontecia sempre que passavam por lugares mais baixos. Bateram à porta e uma boa mulher foi abri-la para eles. Ela lhes perguntou o que desejavam; o Pequeno Polegar lhe disse que eram pobres meninos que tinham se perdido na floresta e que pediam para ser acolhidos durante a noite por caridade. A mulher vendo-os tão bonitos começou a chorar e lhes disse: Ai de mim! Meus pobres meninos, onde viestes parar? Acaso não sabeis que essa é a casa de um ogro que come criancinhas? Oh, senhora! - respondeu-lhe o Pequeno Polegar, que tremia fortemente como os irmãos - que faremos? Não há dúvida de que os lobos da floresta não deixarão de comernos esta noite se não quiserdes acolher-nos em vossa casa. E, assim sendo, preferimos que seja o 
senhor que nos coma; talvez ele tenha piedade de nós, se soubermos dirigir-lhes boas súplicas. A mulher do ogro, que julgou que pudesse escondê-los do marido até o dia seguinte pela manhã, deixou-os entrar e os levou para aquecer-se junto a um bom fogo; pois ali havia um carneiro inteiro no espeto para a ceia do ogro. Quando começavam a aquecer-se, ouviram três ou quatro grandes batidas na porta; era o ogro que voltava. A mulher correu a escondê-los sob a cama e foi abrir a porta. $O$ ogro perguntou primeiro se a ceia estava pronta, e se o vinho fora tirado; em seguida, sentou-se à mesa. Embora o carneiro ainda estivesse sangrento, pareceu-lhe mais saboroso dessa forma. Ele cheirava à direita e à esquerda dizendo que sentia odor de carne fresca. Deve ser - disse-lhe a muIher - o cheiro que sente deste bezerro que acabo de preparar. Sinto cheiro de carne fresca, digo-te mais uma vez - replicou o ogro, olhando a mulher de soslaio - e há aqui algo que não entendo. Ao dizer essas palavras, levantou-se da mesa e foi exatamente na direção da cama. Ah! - disse ele querias então assim me enganar, maldita mulher! Não sei por que não te como também; deve ser porque não passas de um velho animal. Eis a caça que me vem bem a calhar para servir a três ogros amigos meus que devem vir me ver estes dias. Ele os tirou de sob o leito um depois do outro. Os pobres meninos se puseram de joelhos pedindo-lhe perdão; mas estavam lidando com o mais cruel de todos os ogros que, bem longe de ter piedade, já os devorava com os olhos e dizia à mulher que teriam ali apetitosos bocados quando ela fizesse um bom molho para regá-los. O ogro foi pegar uma grande faca e, aproximando-os dos pobres meninos, afiou-a sobre uma comprida pedra que tinha na mão esquerda. Já havia apanhado um deles quando sua mulher lhe disse: Que queres fazer a esta hora? Não terás tempo bastante amanhã pela manhã? Cala-te - retrucou o ogro - eles ficarão mais mortificados. Mas tens ainda tanta carne - replicou a mulher. Tens um bezerro, dois carneiros e a metade de um porco! Tens razão - disse o ogro - dá-lhes uma boa ceia, de que não emagreçam, e põe-nos para dormir. A boa mulher encheu-se de alegria e deu uma boa ceia, mas eles não conseguiram comer, tão amedrontados se achavam. Quanto ao ogro, recomeçou a beber, encantado por ter com que tão bem regalar os amigos. Bebeu uma dúzia de copos mais do que de costume, o que lhe subiu um pouco à cabeça e o obrigou a ir deitar-se.

O ogro tinha sete filhas que não eram ainda mais que criança. As pequenas ogras tinham todas uma tez muito bela, porque comiam carne fresca como o pai; mas tinham pequenos olhos de cor cinza e completamente redondos, o nariz adunco e uma imensa boca com longos dentes muito afiados e muito afastados um do outro. Elas não eram ainda muito malévolas, mas prometiam muito, pois mordiam já as criancinhas para sugar-lhes o sangue. Tinham-nas feito deitar-se na hora certa, estando todas as sete num grande leito, cada uma com uma coroa de ouro sobre a cabeça. Havia no mesmo quarto outra cama do mesmo tamanho; foi nela que a mulher do ogro fez se deitar os sete meninos; depois disso foi deitar-se ao lado do marido. O Pequeno Polegar, que observava que as filhas tinham coroas de ouro na cabeça, e que temia que o ogro tivesse se arrependido de não tê-los degolado naquela mesma noite, levantou-se no meio da noite e, pegando os bonés dos irmãos e o seu foi em completo silêncio colocá-los na cabeça das sete filhas do ogro, depois de lhes ter tirado as coroas de ouro, que pôs sobre a cabeça dos irmãos e sobre a sua, a fim de que o ogro os tomasse por suas filhas, e as filhas pelos meninos que queria degolar. Tudo se passou como ele pensara; pois o ogro, tendo despertado por volta da meia-noite, se arrependeu de ter adiado para o dia seguinte o que podia executar na véspera; saltou então bruscamente da cama e, tomando sua grande faca, disse: Vamos ver como se portam nossos pequenos manhosos; façamo-lo de uma vez. Subiu então, às apalpadelas, ao quarto das filhas e se aproximou do leito onde estavam os menininhos, que dormiam todos, exceto o Pequeno Polegar, que teve muito medo quando sentiu a mão do ogro tatear-lhe a cabeça, tal como fizera com todos os seus irmãos. O ogro, que sentiu as coroas de ouro, disse: Com efeito, ia eu fazer um belo trabalho; vejo que de fato bebi demais ontem à noite. Encaminhou-se em seguida à cama das filhas, onde, tendo sentido os pequenos bonés dos meninos, disse: Ah! Então estão aqui nossos folgazões? Trabalhemos afoitamente. Ao dizer estas palavras, cortou sem hesitação a garganta das sete filhas. Muito contente com a tarefa realizada, voltou para deitar-se junto à mulher. Assim que ouviu o ogro roncar O Pequeno Polegar acordou os irmãos, disse-lhes para se vestirem rapidamente e para segui-lo. Eles desceram silenciosamente para o jardim e pularam o muro. Correram durante quase toda a noite, sempre tremendo e sem saber para onde iam. Tendo despertado, o ogro disse à mulher: Vai lá em cima preparar os pequenos faceiros de ontem à noite; a ogra ficou muito espantada com a bondade do marido, não duvidando em absoluto da maneira pela qual ele entendia que ela os preparasse e crendo que ele the ordenava que os fosse vestir; ao subir, teve uma grande surpresa quando percebeu que suas sete filhas tinham sido degoladas e boiavam no próprio sangue. Ela primeiro desfaleceu (visto que esse é o primeiro expediente que encontram quase todas as mulheres em semelhantes circunstâncias). O ogro, temendo que a mulher levasse muito tempo para realizar a tarefa de que a encarregava, subiu para ajudá-la. Ele não ficou menos estupefato que a mulher quando viu aquele terrível espetáculo. Ah! Que fiz eu? - exclamou - Eles me 
pagarão, os infelizes, e agora mesmo. Jogou prontamente um pote de água no nariz da mulher e, tendo-a feito voltar a si, disse-lhe: Pega-me sem demora minhas botas de sete léguas, a fim de que eu vá apanhá-los. Saiu e, depois de ter corrido bem longe em todas as direções, entrou por fim no caminho que percorriam aqueles pobres meninos, que não se achavam a mais de cem passos da casa do pai. Eles viram o ogro, que ia de montanha em montanha e que atravessava os rios tão facilmente como se fossem pequenos regatos. O Pequeno Polegar, que viu um rochedo escavado próximo do lugar onde estavam, nele escondeu os seis irmãos, e também se introduziu nele, sempre olhando o que o ogro fazia. Este, que se achava muito cansado em virtude do longo caminho que percorrera inutilmente (pois as botas de sete léguas cansam muito seu dono), quis repousar, indo por acaso sentar-se na rocha em que os menininhos estavam escondidos. Como não pudesse mais de fadiga, adormeceu depois de ter repousado por algum tempo, e começou a roncar de modo tão medonho que os pobres meninos não tiveram menos medo do que quando o ogro tinha na mão sua grande faca para lhes cortar a garganta. Tendo tido menos medo dele, o Pequeno Polegar disse aos irmãos que fugissem rapidamente para casa, enquanto o ogro dormia profundamente, e que não se preocupassem com ele. Eles aceitaram seu conselho e logo chegaram à casa. O Pequeno Polegar, tendo-se aproximado do ogro, tirou-lhes silenciosamente as botas e as calçou de imediato. As botas eram muito grandes e muito largas; mas, como eram mágicas, tinham o dom de aumentar ou de reduzir-se de acordo com a perna de quem as calçasse, de sorte que se ajustaram tão bem aos pés e as pernas do menino como se tivessem sido feitas para ele. Ele foi diretamente à casa do ogro, onde encontrou sua mulher pranteando as filhas degoladas. Vosso marido - disse-lhe o Pequeno Polegar - está em grande perigo, pois foi apanhado por um bando de ladrões que juraram matá-lo se ele não Ihes der todo o seu ouro e toda a sua prata. No momento em que o aprisionavam pela garganta, ele me percebeu e me pediu viesse vos alertar de sua situação e vos dissesse para dar-me tudo o que ele tem de valioso, sem que nada guardar, porque, caso contrário, os ladrões o matarão sem misericórdia. Como se trata de algo urgente, ele quis que eu calçasse suas botas de sete léguas, o que fiz para realizar a tarefa com diligência e também para que não julgásseis que sou um inimigo. A boa mulher, muito amedrontada, deu-lhe tudo o que tinha, pois o ogro não deixava de ser muito bom marido, embora comesse as criancinhas. Possuidor então de todas as riquezas do ogro, o Pequeno Polegar voltou à casa do pai, onde foi recebido com muita alegria.

Há muitas pessoas que não concordam com esta última circunstância e que afirmam que o Pequeno Polegar nunca roubou o ogro; que na verdade, ele não teve a pretensão de tomar-lhe as botas de sete léguas, porque só as usaria para correr atrás de outras crianças. Essas pessoas asseguram sabê-lo de fonte fidedigna e mesmo por ter bebido e comido na casa do lenhador. Elas dizem que, quando calçou as botas do ogro, o Pequeno Polegar se dirigiu à corte, onde sabia que se estava em dificuldades por causa de um exército que se achava a duzentas léguas dali, e de uma batalha que acontecera. Afirmam as pessoas que ele foi ao encontro do rei e lhe disse que, caso o desejasse, Ihe relataria as notícias do exército antes do fim do dia. O rei lhe prometeu uma grande soma em dinheiro se fosse bem sucedido. O Pequeno Polegar levou as notícias nessa mesma noite e, essa primeira corrida tendo-o tornado conhecido, ganhava o que queria, pois o rei lhe pagava perfeitamente bem para levar suas ordens ao exército e uma infinidade de damas lhe davam tudo o que ele desejava para ter notícias de seus amantes, tendo sido este seu maior lucro. Algumas mulheres o encarregavam de levar cartas aos maridos, mas lhe pagavam tão mal, representando o montante tão pouca coisa, que ele não se dignava levar em conta o que ganhava com esta tarefa. Depois de ter desempenhado por algum tempo o ofício de correio, e de ter acumulado uma boa quantia, voltou à casa do pai, onde não é possível imaginar a alegria que se teve em revê-lo. Ele deixou toda a família em boa situação. Comprou cargos recém-criados para o pai e os irmãos; e com isso estabeleceu-os a todos, tendo ao mesmo tempo obtido perfeitamente bem seus favores.

\author{
Moral \\ As pessoas não de afligem em absoluto por ter muitos filhos \\ Quando são eles belos, elegantes e bem grandes, \\ Assim como quando tem uma aparência que brilha; \\ Mas se um deles é fraco ou nada diz, \\ É desprezado, censurado, despojado; \\ Às vezes entretanto é esse pequeno ridículo \\ Que fará a felicidade de toda a família.
}




\section{Análise}

O Pequeno Polegar evidencia o diferente. Polegar era o menor de todos e por isso alvo de chacotas e críticas pelos outros. Era considerado incapaz pela sua aparência. Desde os tempos mais remotos, o diferente é discriminado, mas nem todo o diferente. Aos que evidenciam pela beleza ou pela riqueza é reverenciado por todos. Os critérios de julgamento na sociedade da época e até os dias de hoje valorizam a aparência e não a essência. O prestígio e o valor estão ligados ao ter e não ao ser. A essência é desconsiderada em função da aparência. Nesse conto, a conduta de Polegar confirma essa tese. Embora o menor de todos ele conseguiu, com sua inteligência e esperteza, salvar a vida de seus irmãos e de sua família.

Na luta pela sobrevivência vale tudo (mentira, abandono dos filhos). É uma luta árdua, é preciso ser esperto para sobreviver.

\section{Proposta Pedagógica}

Apresentar o texto às crianças, lê-lo uma ou mais vezes. Promover entre os alunos uma conversa sobre a história e se gostaram. O que acharam certo e o que acharam errado. Fazer um levantamento das considerações abordadas pelos alunos e anotar no quadro de giz ou branco. Agrupar as questões afins. Dividir a classe em pequenos grupos. Cada grupo escolherá um personagem (Polegar, os pais, o ogro, a mulher do ogro ) para conversar e depois apresentar à classe sobre o que conversaram. O professor elaborará em conjunto a síntese de cada grupo, que deverá ser anotada em uma folha de papel pardo afixada na sala e, posteriormente, anotada nos cadernos. Essa é uma atividade importante para que os alunos "se apossem " da história. 
Uma outra atividade importante para que os alunos se sirvam da história para compreensão da vida é formular algumas questões e debater com os alunos, tais como: Quem se lembra de alguma história parecida com essa? O que acham do comportamento de Polegar com a mulher do ogro? Por que será que Polegar agiu assim? Em relação aos pais: o que acham de terem abandonado os filhos na floresta? Havia outra alternativa que não abandonar os filhos? Qual? O que você diria a esses pais se os encontrasse? Poderiam fazer alguma coisa diferente?

Após dividir a classe em grupos e por personagem, solicitar que indiquem o que fariam no lugar de cada personagem.

$\mathrm{Na}$ conversa sobre as sugestões apresentadas para as personagens é importante que o professor explicite aos alunos que as suas compreensões sobre a história é uma entre as demais. É possível que as compreensões docentes difiram das dos alunos. O importante é que os alunos se defrontem com as diferentes possibilidades de compreensão para que possam, ao longo de suas experiências de vida, irem construindo seus conhecimentos com autonomia.

\section{A GATA BORRALHEIRA}

Irmãos Grimm

A mulher de um homem rico ficou doente, e quando ela sentiu que seu fim se aproximava, chamou sua única filhinha para junto do seu leito e disse:

- Filha querida, sê devota e boa; então o bom Deus sempre te valerá, e eu olharei por ti lá do céu, e estarei perto de ti.

Então ela fechou os olhos e morreu.

A moça ia todos os dias para o túmulo da mãe e chorava, e continuava devota e boa. Quando o inverno chegou, a neve cobriu o túmulo com um lençol branco. E quando na primavera o sol o tirou de novo, o homem casou-se com outra mulher.

A mulher trouxera consigo para casa duas filhas que eram bonitas e alvas de rosto, mas feias e negras de coração. E então começou uma época ruim para a pobre enteada.

- Essa bobalhona não tem de ficar na sala conosco, - diziam elas.

- Quem quer comer pão, tem de trabalhar para merecê-lo! Para fora com essa criada!

Elas Ihes tomaram os bonitos vestidos, deram-lhe um avental cinzento para vestir e tamancos de pau para calçar.

- Olhem só para a bela princesa, como está enfeitada! - exclamaram elas, e levaram a moça para a cozinha.

Lá ela tinha de fazer serviços pesados, desde a manhã até a noite, levantar-se antes do amanhecer, carregar água, acender o fogo, cozinhar e lavar. E ainda por cima as irmãs Ihe causavam 
toda sorte de desgostos, zombavam dela e esparramavam as ervilhas e as lentilhas na cinza do borralho, para que ela tivesse de catá-las e separá-las de novo. À noite, cansada de trabalhar, ela não tinha cama, mas tinha que deitar nas cinzas ao lado do fogão. E porque ela, por causa disso, parecia sempre empoeirada e suja, elas a chamavam de gata borralheira.

Quando certo dia o pai ia viajar para uma feira, perguntou às enteadas o que elas queriam que ele lhes trouxesse.

- Lindos vestidos, - disse uma.

- Pérolas e pedras preciosas, disse a outra.

- E tu, Gata Borralheira, disse ele, - o que queres ganhar?

- Pai, o primeiro raminho que no caminho de volta roçar o teu chapéu, quebra-o e traze-o para mim.

Então ele comprou para as duas irmãs lindos vestidos, pérolas e pedras preciosas, e no caminho de volta, quando atravessava um mato verde, um ramo de nogueira esbarrou nele e arrancouIhe o chapéu. Então ele quebrou o ramo e levou-o consigo.

Quando chegou em casa, deu às enteadas o que elas lhe pediram, e à Gata Borralheira ele entregou o raminho de nogueira.

Gata Borralheira agradeceu, levou o raminho para o túmulo da sua mãe e plantou-o ali, e chorou tanto, que suas lágrimas o molharam e regaram.

O ramo cresceu e transformou-se numa bela árvore. Gata Borralheira ia lá três vezes ao dia, todos os dias, e chorava e rezava debaixo da árvore, e cada vez que vinha um passarinho branco, pousava na árvore, e sempre que Gata Borralheira exprimia um desejo, o passarinho lhe jogava o que ela desejara.

Certa vez aconteceu que o rei deu uma festa que devia durar três dias, e para a qual todas as moças bonitas do reino foram convidadas, para que seu filho escolhesse uma noiva dentre elas. Quando as duas ouviram que elas também eram convidadas, ficaram alegres e contentes, chamaram Gata Borralheira e disseram:

- Penteia nossos cabelos, escova nossos sapatos e aperta nossos colchetes; nós vamos à mostra de noivas no palácio real.

Gata Borralheira obedeceu, mas chorou, porque gostaria de ir ao baile, e pediu à madrasta que a deixasse ir.

- Tu, Gata Borralheira, - disse ela, - coberta de pó e sujeira, queres ir à festa? Não tens vestidos nem sapatos e queres dançar?

Mas como a moça não parava de suplicar, ela disse por fim:

- Derramei uma bacia de lentilhas nas cinzas; se separares as lentilhas em duas horas, poderás vir conosco.

A moça saiu pela porta dos fundos, correu para o jardim e chamou:

- Pombinhas mansas, rolinhas brancas, todos os passarinhos debaixo do céu, venham ajudar-me a catar as lentilhas,

"as boas no potinho,

as ruins no buchinho."

Então vieram voando e entraram pela janela da cozinha duas pombinhas brancas e atrás delas as rolinhas, e finalmente todos os passarinhos debaixo do céu entraram ruflando as asinhas e pousaram nas cinzas do borralho. $E$ as pombinhas baixaram as cabecinhas e começaram, pic-pic-pic, e os outros também, pic-pic-pic, a bicar, e a pôr todas as lentilhas boas na bacia. E mal passou uma hora, eis que eles terminaram tudo e voaram embora. Então a moça levou a bacia para a madrasta, muito contente, pensando que agora poderia ir à festa.

Mas a madrasta falou:

- Não Gata Borralheira, tu não tens roupa e não sabes dançar; todo mundo só vai caçoar de ti.

E quando a moça chorou de novo, ela disse:

- Se puderes catar das cinzas e escolher duas bacias de lentilhas em uma hora então poderás vir, - e pensou: "Isto ela nunca vai conseguir".

Quando ela derramou as duas bacias de lentilha nas cinzas, a moça saiu correndo pela porta dos fundos para o jardim e chamou:

- Pombinhas mansas, rolinhas brancas, todos os passarinhos do céu, venham ajudar-me acatar as lentilhas,

"as boas no potinho,

as ruins no buchinho." 
Então vieram voando e entraram pela janela da cozinha duas pombas brancas e atrás delas as rolinhas, e finalmente todos os passarinhos debaixo do céu entraram ruflando as asinhas e pousaram nas cinzas do borralho. E as pombinhas baixaram as cabecinhas e começaram, pic-pic-pic, e os outros também, pic-pic-pic, a bicar, e a pôr todas as lentilhas boas na bacia. $E$ antes que passassem meia hora, eles terminaram tudo e voaram todos embora. Então a moça levou as bacias para a madrasta, contentíssima, pensando que agora podia ir junto com elas para a festa.

Mas a malvada mulher falou:

- Nada disso vai te adiantar; não virás conosco, porque não tens vestido e não sabes dançar; nós ficamos com vergonha de ti.

E com isso ela virou as costas à moça e saiu apressada junto com suas filhas orgulhosas.

Quando, então, não estava mais ninguém em casa, Gata Borralheira foi para o túmulo da sua mãe debaixo da nogueira e falou:

"Sacode teus ramos, querida nogueira,

Joga ouro e prata sobre a Borralheira."

Então o passarinho jogou-lhe um vestido de ouro e prata, e sapatinhos bordados de seda e prata. Sem perda de tempo, Gata Borralheira vestiu-se e foi para a festa. As irmãs e a madrasta não a reconheceram e pensaram que ela era uma princesa estrangeira, tão linda ela estava no seu vestido de ouro. Elas nem pensaram na Gata Borralheira, achando que ela estava em casa, na cozinha, catando lentilhas nas cinzas do fogão.

O filho do rei veio ao seu encontro, tomou-a pela mão e dançou com ela. Ele não quis, dali em diante, dançar com mais ninguém, e não soltava a mão da moça, e quando vinha outro para convidá-la, ele dizia:

- Esta dançarina é minha.

Gata Borralheira dançou até anoitecer, então ela quis ir para casa. Mas o filho do rei falou:

- Eu vou junto para te acompanhar, - pois ele queria ver onde era a casa da bela moça.

Ela porém escapou dele e se escondeu dentro do pombal. Então o príncipe esperou até que chegasse o seu pai e lhe disse que a moça estranha pulara para dentro do pombal. O velho pensou: "Será que não é a Gata Borralheira?", e tiveram de trazer-Ihe a machadinha para ele poder rachar o pombal; mas dentro não havia ninguém.

Quando a madrasta e suas filhas voltaram, Gata Borralheira estava deitada nas cinzas, com suas roupas sujas, e uma pequena lâmpada de azeite ardendo tristonha sobre fogão - pois Gata Borralheira pulara ligeira pela parte detrás do pombal e correra para a nogueira do cemitério. Lá ela deixara suas lindas roupas sobre o túmulo, e o passarinho as levara embora; e ela voltara suas lindas roupas sobre o túmulo, e o passarinho as levara embora; e ela voltara para o seu trabalho, na cozinha, com o seu velho avental cinzento.

No dia seguinte, quando a festa recomeçou e os pais e as irmãs já tinham saído, Gata BorraIheira foi até a nogueira e disse:

"Sacode teus ramos, querida nogueira,

Joga ouro e prata sobre a borralheira."

Então o pássaro jogou-lhe um vestido ainda mais imponente que o da véspera. $E$ quando a moça apareceu na festa com aquele vestido, todo mundo se espantou com a sua beleza. O príncipe porém já esperava por ela, e tomou-a logo pela mão e só dançou com ela. Quando os outros vinham convidá-la, ele dizia:

- Esta dançarina é minha.

Quando a noite caiu, ela quis ir embora, e o príncipe a seguiu, pois queria ver onde ela entraria, mas ela lhe escapou e fugiu para o jardim atrás da casa. Ali havia uma árvore grande e formosa, carregada de lindas pêras. Gata Borralheira subiu por entre os galhos, ágil como um esquilinho, e o príncipe não sabia onde ela foi parar.

Mas ele esperou até que chegasse o pai e lhe disse:

- A moça estranha fugiu de mim, e acho que ela pulou na pereira.

O pai pensou: "Será que não é a Gata Borralheira?" - Mandou buscar a machadinha e derrubou a árvore, mas não havia ninguém nela.

Quando as outras voltaram, Gata Borralheira estava deitada lá nas cinzas, como sempre porque ela pulara ao chão do outro lado da árvore, devolvera as lindas roupas ao pássaro da nogueira, e vestira o seu avental cinzento. 
No terceiro dia, quando os pais e as irmãs já tinham saído, Gata Borralheira voltou para o túmulo da mãe e disse à arvorezinha:

"Sacode teus ramos, querida nogueira,

Joga ouro e prata sobre a borralheira."

Desta vez o pássaro the jogou um vestido que era tão suntuoso e cintilante como nenhum dos anteriores, e os sapatinhos eram de ouro puro. Quando ela chegou à festa naquele vestido, todo mundo ficou sem palavras, tal era o espanto. O príncipe só dançou com ela, e quando alguém vinha convidá-la, ele dizia:

- Esta dançarina é minha.

E quando anoiteceu, Gata Borralheira quis ir embora, e o príncipe queria acompanhá-la, mas ela Ihe escapou tão ligeira que ele não conseguiu segui-la. Mas o príncipe usara de ardil, mandando untar com piche a escadaria inteira. E então, ao fugir, o sapatinho esquerdo da moça ficou grudado num degrau.

O príncipe levantou-o, e era pequenino e gracioso e todo de ouro. No dia seguinte ele foi ao seu pai e lhe disse:

- Nenhuma outra será minha esposa a não ser aquela cujo pé couber este sapatinho de ouro.

Então as duas irmãs ficaram contentes porque tinham pés bonitos. A mais velha entrou no quarto e quis experimentar o sapatinho, e sua mãe ficou junto dela. Mas ela não conseguiu fazer caber nele o dedão do pé. Então a mãe lhe entregou uma faca e disse:

- Corta fora esse dedão! Quando fores rainha, não precisarás mais andar a pé.

A moça decepou o dedo, forçou o pé para entrar no sapatinho, disfarçou a dor e saiu ao encontro do príncipe. Então ele pôs como noiva no seu cavalo e partiu com ela. Mas eles tinham de passar pelo túmulo, onde as duas pombinhas estavam pousadas na nogueira e elas cantaram:

"Purr-purr, purr-purr, purrinho,

Sangue no sapatinho,

Não cabe no seu pé,

A noiva esta não é".

Então o príncipe olhou para o pé e viu o sangue escorrendo. Ele fez o cavalo dar meia-volta, devolveu a falsa noiva à casa e disse que ela não era a certa, e que a outra irmã provasse o sapato. Então esta entrou no quarto, e conseguiu enfiar os dedos do pé, mas o calcanhar era grande demais. Então a mãe lhe entregou uma faca e disse:

- Corta fora um pedaço do calcanhar! Quando fores rainha, não precisaras mais andar a pé.

A moça decepou um pedaço do calcanhar, forçou o pé no sapato, disfarçou a dor e saiu ao encontro do príncipe. Então ele pôs no seu cavalo como sua noiva e partiu com ela. Quando eles passaram pela nogueira, lá estavam as duas pombinhas, que cantaram:

"Purr-purr, purr-purr, purrinho,

Sangue no sapatinho,

Não cabe no seu pé,

A noiva esta não é."

Ele olhou de novo para o seu pé e viu o sangue escapando e subindo pela meia branca, toda vermelha. Então ele fez o cavalo voltar e devolveu a falsa noiva à sua casa.

- Esta não é a certa, - disse ele, - a senhora não tem outra filha?

- Não, - disse o marido; - só da minha esposa falecida temos aqui uma pequena e insignificante Gata Borralheira; não é possível ser ela a noiva.

O príncipe disse que a mandasse subir, mas a madrasta respondeu:

- Oh, não, a moça é muito sujinha, ela não pode se mostrar a ninguém.

Mas ele queria vê-la de qualquer forma, e tiveram de chamar a Gata Borralheira. Então ela lavou as mãos e o rosto, apareceu e curvou-se diante do filho do rei, que the estendeu o sapatinho de ouro.

Aí ela sentou-se sobre um banquinho, tirou o pé do pesado tamanco de madeira e enfiou-o no sapatinho, que se adaptou com perfeição. E quando ela se levantou, e o príncipe a fitou no rosto, reconheceu a bela moça que dançara com ele, e exclamou:

- Esta é a noiva verdadeira! 
A madrasta e as duas irmãs se assustaram e empalideceram de raiva. Ele porém pôs a Gata Borralheira sobre o seu cavalo e partiu com ela.

E quando eles passaram pela nogueira, as duas pombinhas brancas arrulharam:

"Purr-purr, purr-purr, purrinho,

Sem sangue no sapatinho,

Que coube no seu pé,

A noiva é esta, é!"

\section{Análise}

É um conto cujo tema vai abordar as diferenças de tratamento entre os membros da família e, também, as diferenças entre os estratos sociais. Uns são acolhidos mais calorosamente, outros não.

São contos que permeiam a vida do ser humano em todas as fases de sua

existência, respondendo aos anseios mais profundos. Bettelheim, ${ }^{102}$ referindose a esse conto, diz:

Nenhum outro conto relata tão bem como 'Borralheira' as experiências internas da criança pequena nos espasmos da rivalidade fraterna, quando ela se sente desesperadamente marginalizada pelos irmãos e irmãs. Borralheira é humilhada e rebaixada pelas irmãs adotivas; a madrasta sacrifica os interesses de Borralheira em favor dos das irmãs; deve executar os trabalhos mais sujos e mesmo fazendoos bem, não é aceita por eles; só Ihe fazem mais exigências. É como se sente a criança quando é devastada pelas desgraças da rivalidade fraterna. Embora as tribulações e humilhações de Borralheira possam parecer exageradas ao adulto, a criança arrebatada pela rivalidade fraterna sente que 'É assim comigo; é como me maltratam ou gostariam de maltratar; é como me menosprezam'. E há momentos - às vezes longos períodos - em que, por razões internas, a criança se sente desta maneira mesmo quando sua posição entre os irmãos não pareça dar motivos para isso.

Eis a razão porque $A$ Gata Borralheira é um dos contos mais lido pelo público infantil de ontem e de hoje, pois trata de um comportamento muito presente no in-

${ }^{102}$ BETTELHEIM, op.cit., p.278. 
consciente coletivo da esfera familiar. E é justamente por isso que a criança que vive na condição de irmãos se identifica com a personagem.

Borralheira, que viveu tal situação, conseguiu superá-la, fosse pela presença do elemento mágico, fosse pela sua ação em busca de realizar seu sonho, tornou-se o ponto de encontro com esse leitor em conflito consigo mesmo.

Destacamos, também, a procura da verdade pelo príncipe que valorizam a essência e não a aparência.

\section{Proposta Pedagógica}

Ler a história para e com os alunos. Após a leitura, abrir um diálogo com a classe sobre situações semelhantes à Gata Borralheira, vividas, pelos alunos, na família. Na vida de cada pessoa, sempre haverá situações da intimidade familiar para se superar, ou situações de outros, por ela conhecidas. Como as pessoas discriminadas no ambiente familiar costumam reagir? Como reagiu a Gata Borralheira à situação? Acomodando-se ou reagindo? Borralheira, de maneira passiva e silenciosa, conseguiu desafiar a esperteza da madrasta e das irmãs. Conquistou sua dignidade e liberdade.

Qual o motivo que levou a madrasta e as filhas a agirem dessa forma com a Gata Borralheira? Existem pessoas, ainda hoje, que agem como elas? Vocês conhecem pessoas que são ou foram humilhadas e superaram tal situação?

O conto pode incentivar uma pequena dramatização. Para isso o professor, com a ajuda dos alunos, pode organizar o espaço, as personagens, o cenário, os adereços e outros detalhes. Após a apresentação, é interessante abrir espaço para que os alunos se expressem sobre o que sentiram representando o seu personagem. 


\section{O Patinho Feio}

\section{Hans Christian Andersen}

Como estava lindo o campo naquele verão!

Os trigais agitavam, ao sopro da brisa, as suas lindas espigas cor de ouro; a aveia, ainda verde, apresentava um belo viço; e os feixes de feno, amontoados por aqui e por ali, encham o campo com o seu delicado perfume.

As cegonhas, do alto das suas longas pernas vermelhas, olhavam para as águas azuis do tanque, resmungando em egípcio, língua que na infância tinham aprendido da senhora sua mãe, quando as aquecia em seu ninho!

Lá, ao longe, limitando os campos cultivados e os prados, estendia-se a floresta, interrompida em alguns pontos por lagos arredondados, rasos de água.

Tudo se harmonizava tão bem nas cores, nas formas, nas proporções, que a gente se sentia feliz e contente em passar alguns dias naquele delicioso lugar!

A um lado, erguia-se uma velha casa, cercada de largos fossos.

O sol a envolvia toda em seus raios dourados, aquecendo-a, alegrando-a.

Dos muros, que cercavam os seus terreiros, desciam grandes folhas de bardana a tocar quase o chão; tão grandes que uma criança poderia ocultar-se por baixo de uma delas, sem lhe aparecer um pontinho do corpo!

Foi justamente aí, tendo por teto esse verde dossel, que a abrigava do sol e da chuva, que uma linda pata branca construiu um dia o seu ninho, nele chocando alguns ovos.

No momento em que começa esta história ela lá estava ainda no ninho, esperando, ansiosa, que seus filhinhos saíssem da casca...

Não tinha recebido até então nenhuma visita.

Suas amigas, e ela possuía muitas, preferiam andar lá pelas margens do tanque, a cujas águas de vez em quando se atiravam em longos banhos, do que virem até aí para lhe dar um dedinho de prosa!

E ela, presa ao ninho, pacientemente, por longos dias, sem dele quase arredar pé!

Já estava se sentindo um pouco fraca!

Um dia, enfim, os patinhos, um após outro, começaram a picar os ovos!

Ai que alegria para a pobre mãe!

Depois, ouviu-se pi-pip!

Eram os filhotes que já estendiam os pescocinhos pela abertura furada na casca.

Depois... rap-rap!... era a ninhada toda fora das escuras prisões. Os patinhos empurravam-se uns aos outros por baixo das penas maternas.

A ninhada toda, não. Um ovo restava, ainda, para ser picado!

Mas os que tinham nascido, afastando a plumagem da pata, que os cobria, punham p'ra fora as vivas cabecinhas, olhando para todos os lados, por sob as folhas.

A mãe não lhes ralhava, porque a cor verde não faz mal à vista...

- Como é grande o mundo! disse um deles.

- Ai, tontinho, pensa, então, você que o mundo acaba ali? perguntou a pata; oh! não: ele estende-se muito além... vai p'ra lá do jardim... até os campos do sr. Vigário!... Eu é que nunca pus lá meus pés... Mas, digam-me: já saíram todos da casca? continuou ela, levantando-se... Ah! falta ainda um, o ovo maior!... Meu Deus! quanto tempo!...

$\mathrm{E}$, com ar contrariado, tornou a deitar-se.

- Bom dia!... Como vai, então, isto por aqui? perguntou uma velha pata, que resolveu, afinal, vir visitar a patinha branca.

- Vai tudo correndo bem, felizmente, minha boa amiga! Só resta este, que me está dando um grande trabalho para chocar! Mas, repare, querida, nos meus filhotes já nascidos! Não são todos muito bonitos?... Parecem com o pai, não é verdade? E por falar nesse ingrato... até agora não me veio ver, nem aos filhos!

- Mostre-me um instante esse ovo que não quer picar! pediu a visita... Ah! mas isto é um ovo de perua! A mim também já me sucedeu uma vez cousa igual! E que trabalhos tive eu com o pequeno!... Porque, esses seres têm um medo horrível à água. Nunca pude fazê-lo entrar no tanque. Nem conselhos, nem ralhos, nem bicadas... a nada obedecia... Mas, deixe-me ver outra vez o ovo... Sim, é positivamente de perua. Abandone-o por aí, e vá antes, ensinar os outros a nadarem...

— Ah! isso não... e já que perdi algum tempo com ele, posso esperar mais um dia ou dois...

- Faça como entender! replicou a velha pata, e retirou-se.

O ovo começou, enfim, a ser picado.

Ouvia-se perfeitamente as pancadinhas que lhe dava o patinho do lado de dentro. 
Meia hora depois o pequeno disse pi-pip! e pulou pra fora da casca.

$\mathrm{Ai}$, que patinho feio!

A mãe olhou para ele um instante, dizendo consigo:

- Como é grande! Não se parece com os irmãos em cousa nenhuma. Será realmente um peruzinho? Veremos isso amanhã, quando formos nadar!

Amanheceu um dia lindo.

Os raios solares batiam sobre as folhas das bardanas, deixando-as lustrosas como espelhos.

A pata, seguida da ninhada, tomou o caminho do tanque.

Eles, os filhotes, iam muito contentes, a correr e a saltar, por aqui e por ali, atrás de algum insetozinho que voava rente ao chão.

De vez em quando lá um enroscava o pé, dando uma cambalhota.

Logo que chegou ao tanque, a pata — platsch — saltou à água.

E, nadando, disse: rap... rap!

Os pequenos, assim chamados, também se atiraram logo à água, pondo-se a nadar.

Que cousa deliciosa era a água!

Um, e outro, e outro, mergulhavam de cabeça para baixo, até o fundo do tanque. Mas logo reapareciam à tona d'água, nadando, nadando para todos os lados!

As pernas moviam-se-lhes com facilidade, e a petizada toda se mostrava contente, inclusive o feio patinho cinzento.

A pata, que não o perdia de vista, notando a sua destreza, ficou mais alegre...

- Não; não é peru! disse ela para si; perus não sabem nadar assim com tanto desembaraço e elegância. Já não tenho dúvida que é também um patinho e meu filho legítimo!... Mas agora reparo que já não me parece tão feio como ao nascer.

- Rap... rap! continuou, em voz alta, dirigindo-se aos patinhos: basta de nadar por hoje! Vamos agora ao cercado dos patos... Quero apresentá-los à sociedade!

E pulou para a margem do tanque.

Os patinhos seguiram-n'água.

- Ouça este conselho, meus filhos: não se afastem muito de mim! Tolinhos como são, desconhecem ainda quem é o nosso amigo ou nosso inimigo. Tomem sentido principalmente com o gato!...

E pondo-se a andar, a pata e mais os patinhos encaminharam-se para o cercado onde moravam os patos.

Que ruído lá se fazia!

De um lado, os patos; de outro, as galinhas, disputavam a cabeça de uma enguia, puxando daqui, puxando dali.

- Aí está uma cena digna de ver-se! disse a pata, chamando a atenção dos filhos, mas estendendo também o seu bico para apoderar-se da enguia... Reparem!...

Bem! atenção!... é preciso agora arranjar uma linda compostura... Aprumem-se nas pernas com certa elegância, para saudar o velho pato que ali vem! Ah! esse sim, é o mais distinto habitante deste cercado! Dizem que é castelhano, que nasceu na Espanha! Olhem a fita vermelha que ele traz amarrada a uma das pernas! Estão vendo? Ah! aquilo é a maior distinção que se pode conferir a um pato! Significa que não desejam perdê-lo, e que homens e animais devem admirá-lo! Vamos... firmes!... Então, que é isto? Não ponham os pezinhos assim tão separados... é muito desgracioso!... um patinho bem educado deve afastar os pés com certo cuidado! Vejam como eu faço: olhem... assim... aprenderam? Depois, inclinem a cabeça de leve, e digam: rap!

Os petizes obedeceram e saíram-se bem da prova. egoísmo.

Os velhos patos, que os cercavam, a examiná-los curiosamente, não puderam conter o seu

- Ora, não faltava mais nada! exclamaram; patos e mais patos! como se já não fossemos bastantes! E aquele ali? Aquilo será também um pato? Não, esse cá não fica!

$\mathrm{E}$, logo, um pato veterano, que não simpatizara como a feia cara do patinho cinzento, se atirou sobre ele ás bicadas.

O pobrezito teve tremuras nas pernas, e agachou-se todo medroso, perto da mãe.

— Oh! deixe-o, deixe-o! implorou esta; o coitadinho não faz mal a ninguém!...

- Bem sei; mas é tão feio e desajeitado, que só mesmo a bicadas! respondeu o agressor.

Nesse instante, chegava o pato da fita vermelha.

- Ai, que lindos são os seus filhos! disse; todos bem conformadinhos! Menos aquele, ali! Hum!... mas como ele é feio! Nasceu fora de tempo? Eu bem desejaria que você o tivesse mais elegante! 
- Sim, não é bonito este meu filho, concordo! disse a mãe procurando desfazer a má impressão do fidalgo; mas tem um gênio adorável, sabe nadar com as exigências da arte, e, direi mesmo, com mais perfeição do que todos os irmãozinhos! Ele crescerá, estou certa, tão lindo como os outros, e há de ser também elegante! É questão de esperar com paciência! O pobrezito demorou-se muito dentro do ovo!

Enquanto assim falava, a pata alisava com o bico a penugem do pescoço do filho infeliz, acariciando-o docemente.

- Demais, continuou, é um pato, e como tal não é muito necessário que seja bonito! Se fosse uma pata... ah! então, sim, seria doloroso que lhe faltasse beleza!...

Mas, sendo varão, basta que cresça forte e valente para fazer carreira no mundo! Enfim... os seus irmãos são lindos! terminou, consolada, a pata.

- Meus filhos, disse depois, dirigindo-se à ninhada; façam agora de conta que estão em sua casa: trate cada qual de si... E se acharem algures uma cabeça de enguia, tragam-m'a aqui para dividi-la por todos.

O pobre patinho cinzento, porém, logo que se afastou das vistas protetoras de sua mãe, foi, devido ao seu feio aspecto, bicado, batido, atropelado não só pelos velhos patos, como pelas galinhas e perus.

— É feio como um jacaré! diziam, perseguindo-o.

O galo índio, que, por nascer de esporas, se julgava um rei, arrepiou as penas, como uma embarcação de velas enfunadas, e arremeteu furiosamente, vermelho, até os olhos, contra ele.

O pobre patinho não sabia o que fazer.

Doía-lhe o coração de se ver tão feio e maltratado por todos os patos do cercado!

Não tinha esperanças de que o tratassem melhor.

Os próprios irmãos o repeliam à medida que ia crescendo. Diziam-lhe a todo o instante:

- Arre! Vá ser feio p'ra lá!... Seria bem feito que o gato te comesse!

A mãe, uma vez, estando mais nervosa, empurrou-o com o bico dizendo-lhe:

- Eu bem desejava que fosses p'ra muito longe daqui!

Era demais!

Todo o mundo o desprezava: os patos não o queriam; as galinhas e os galos lhe davam esporadas; os parentes o repeliam, e até a criada, que distribuía comida às aves, magoou-lhe um dia as costas com um pontapé!

Resolveu, pois, fugir, esconder-se, ir para muito longe.

Uma manhã, mal o sol apareceu no horizonte, ele tomou o caminho da floresta.

Os passarinhos, ao avistá-lo, fugiam espantados das moitas e dos ninhos.

- E tudo isto porque não sou bonito! pensou ele, tristemente.

Mas, fechando os olhos, continuou sempre o seu caminho, sem deter-se.

Uma hora depois parava junto do grande tanque, onde viviam os patos selvagens.

Estes, assim que o viram, exclamaram admirados:

- Quem é este aqui?!

O patinho, lembrando-se dos conselhos de sua mãe, girou em torno dos pés, saudando os novos camaradas com a maior elegância que pôde.

- Irra! disse um mais jocoso, podes gabar-te de ser feio! Mas isso pouco importa; serves para nosso camarada... contanto que... não te metas a engraçado com alguma senhorita da nossa família! Casamento cá na nossa raça, sim, não consentiremos!

$\mathrm{Ai}$, pobre patinho! Nem sombra de casamento lhe passava pela cabeça! O que ele desejava o lugarzinho no mundo, onde pudesse viver tranqüilo... Um pouco d'água para beber, um cantinho para dormir, a liberdade de catar um grãozito, eis toda a sua ambição. Dessem-lhe isso, apenas isso, que era ainda grande o favor que Ihe fariam!

Consentiram, afinal, que ficasse. Ele ficou.

Dois dias passou neste doce sossego, quando viu chegarem, vindo de longe, dois gansos selvagens.

Eram ainda novos também, sem grande experiência das coisas do mundo. E, por isso, em vez de gentis e delicados, mostraram-se um tanto grosseiros com o patinho.

- Olha, camarada, disse um deles, atrasando o vôo; é tão feio que ficaríamos bem contentes em levar-te conosco. Queres acompanhar-nos? Ficarás também uma ave de arribação! Aqui pertinho, do outro lado deste tanque, ha gansas selvagens lindíssimas, donzelas quase todas. Casar-te-ás com uma delas, e talvez sejas muito feliz!

Isto dizendo continuaram a voar zombando ainda do patinho cinzento.

De repente, ouviu-se um pif-paf! e os dois gansos selvagens caíram no mesmo instante n'água, que se tingiu do seu sangue! 
Os caçadores, que os atiraram, achavam-se escondidos à beira do tanque; alguns, cavalgavam galhos de árvores, nascidas rente à margem, negaceando as aves aquáticas.

Pif-paf! e bandos de gansos selvagens voaram dos juncais.

Ouviram-se ainda muitos outros tiros de espingarda. Era uma grande caçada. águas.

Pequenas nuvens de fumaça azul saíam das árvores sombrias, espalhando-se por sobre as

Apareceram cães no tanque. Platsch, platsch, e os juncos, ao peso dos seus corpos, curvavam-se de todos os lados.

O pobre patinho estava aterrorizado!

Escondeu a cabeça entre as asas, esperando, resignado, a sua sorte.

No mesmo instante, passou a seu lado, correndo, um grande e terrível cão. A língua pendiaIhe da boca vermelha e cheia de baba; seus olhos faiscavam de raiva.

Olhou para o patinho, todo encolhido de medo, mostrou-lhe seus dentes agudos, e platsch, platsch, atirou-se n'água, sem com ele importar-se!

- Deus seja louvado! exclamou o patinho; o ser feio nem sempre é aborrecido!

E deixou-se ficar quietinho, sem mover-se, enquanto os tiros se repetiam e as balas sibilavam por entre os juncos!

Ao cair da tarde cessou, enfim, o ruído. O patinho, porém, não se moveu do lugar! Esperou ainda uma boa meia hora!

Depois olhou para todos os lados, e não vendo nada que o ameaçasse, fugiu a toda a pressa daquele perigoso lugar.

O céu estava negro, ameaçando terrível temporal.

Felizmente, antes de desencadear a tempestade, o patinho chegou a uma mísera cabana, tão velha e tão arruinada, que se não poderia dizer de que lado ia cair!

Era já noite fechada.

O vento soprava tão rijo, que ele teve de abrigar-se encostado à cabana!

la tudo de mal a pior!

Reparou, então, que uma das portas se desprendera dos gonzos, permitindo-lhe, por um desvão, refugiar-se no interior da velha casa.

E por aí entrou com o coração mais desafogado!

Moravam na casa uma velha, um gato preto que ela chamava seu neto, e uma galinha.

O bichano era muito amigo do calor do fogão e do colo da sua dona, e tinha muitas habilidades: sabia arquear as costas e ronronar alegremente. Às vezes, quando a avó lhe passava as mãos pelo corpo, alisando-o, fazia saltar dos pêlos algumas rápidas chispas!

A galinha era um tanto anã: tinha mui pequenas as pernas; motivo por que the deram o nome de Perna Curta.

Era também muito estimada da velha, que Ihe chamava sua filha, e para quem punha uns ovos brancos, que eram uma delícia!

Logo que o patinho entrou, o bichano se pôs a miar e a galinha a gritar o seu cocoricó, que não tinha mais fim!

- Por que, meus filhos, esse barulho todo? perguntou a velha, olhando ao redor de si. E como tinha pouca vista, julgou que era uma gorda pata que lhe entrara pela casa.

- Ah-ah! que bela surpresa! exclamou; vamos ter também ovos de pata d'ora em diante! Mas será mesmo uma pata? Ai, que se for um pato, eu meto-o logo na panela... O melhor é que esperamos uns dias a ver o que na verdade isto é!

E esperou três semanas, mas de ovos nem sinal.

Os verdadeiros donos da casa eram, porém, Bichano e Perna-Curta, e como tal se julgavam. Na sua fala só empregavam o pronome - NÓs -

Nós e o mundo, diziam; porque cuidavam que a metade do mundo, a melhor metade mesmo, resumia-se, apenas, neles dois!

Um dia, em palestra, o patinho julgou que podia ter também opinião.

— Eu penso... ia ele dizendo.

A galinha encolerizou-se logo.

- Você sabe pôr ovos? perguntou com rudeza.

Não.

- Ah! se não sabe, tenha a bondade de calar-se e de não dizer que pensa...

O bichano saltou também do seu lado.

- Você sabe arquear o dorso? Você sabe ronronar? Você sabe fazer saltarem as chispas do pêlo?... Ah! não sabe? Então cale-se. Quem não sabe fazer estas coisas, não tem direito de meter sua colher torta na conversa de gentes criteriosas! 
E o patinho, muito triste, foi deitar-se, resignado, a um canto do aposento.

De repente, porém, o interior da cabana iluminou-se todo.

A luz do sol, viva e alegre, penetrava pelas muitas frestas das paredes.

Aquela claridade lhe chegou também à alma. Sentiu-se outro. Teve ímpetos de sair, de atirarse à água, de nadar, nadar, nadar, na imensidade azul de qualquer tanque...

Levantou-se, e foi dizer à galinha o seu desejo.

- Quê? O quê? Que é que está aí a dizer? Nadar? Mas isso são fantasias de quem não tem o que fazer! Olhe: vá pôr ovos ou fazer ron-ron! que todos esses caprichos logo Ihe passarão!

— E, entretanto, como é agradável nadar! insistiu o patinho; como é doce sentir a gente a água fechar-se sobre o corpo, por cima da cabeça, ao se dar um mergulho até o fundo do tanque!

A galinha resolveu ser irônica.

— Na realidade, é uma bela cousa o que você está dizendo! Que doçura o nadar!... Que delícia o mergulhar!...

Depois, em tom sério, continuou:

- Olhe, quer saber de uma cousa? O que me parece é que você tem mole o miolo!... Pergunte ao Bichano, que é um ente de muito juízo, se ele gosta de nadar e de mergulhar! Pergunte-o mesmo à nossa ama, que é a experiência viva das coisas do mundo... Pensa você, então, que ela tivesse algum dia desejos de nadar e de sentir a água se the fechar por cima da cabeça?!

— Ah! vocês não me podem compreender!...

- Como é que diz?! Não o podemos compreender?! Ora, o vaidoso!... Ora, o sabichão! Quem é que não compreende!... Julga-se, acaso, você mais instruído que o Bichano e a avozinha?

- Não, não era isso o que eu queria dizer... não estava a falar de mim.

- Ora, pequeno, não venha p'ra cá com as suas aritméticas... Dê antes graças a Deus pelos benefícios que está recebendo... Que mais quer? Encontra, no meio de uma tempestade, um quarto bem quente onde acolher-se; entra a pertencer a uma sociedade que só honra a quem dela faz parte... e põe-se ainda a inventar fantasias, que só servem para torná-lo insuportável! Com franqueza: não é nada alegre viver com você! Acredite-me; sou muito sua amiga, e só lhe posso falar esta linguagem rude, mas leal, da amizade: Deixe-se de mergulhos, de tanques e de águas, e trate de por ovos ou de fazer ron-ron!

- O que mais me conviria, respondeu o patinho, sei eu... Era correr mundo...

- Como quiser! disse a galinha.

O patinho saiu, então, da cabana, e dirigiu-se ao primeiro tanque em cujas águas se atirou, nadando e mergulhando à vontade.

Mas todos os animais que encontrara pelo caminho, pássaros, borboletas, abelhas, dele fugiram horrorizados com a sua fealdade.

Chegou o outono.

As folhas, amarelecidas, redemoinhavam nos ares, sopradas pelo vento.

Nuvens de cor pardacenta anunciavam o frio que ia lá pelos altos. De vez em quando caíam chuvas de granizo e de neve!

Pousado na sebe, um corvo encolhia-se todo, tiritando!

O pobre patinho não se achava na realidade muito à vontade.

Tremia, também de frio!

Uma tarde, à hora em que o sol ia, glorioso de luz, desaparecer no poente, um bando de soberbas aves aquáticas levantou o vôo das margens do tanque.

Nunca vira o patinho aves tão lindas! Tinham as penas da brancura do jaspe, e o longo pescoço de uma graça modelar!

Eram soberbos cisnes.

O som de sua voz era de um timbre todo especial!

Com as lindas asas abertas, refulgindo aos últimos raios do sol, eles se afastavam daquela região, indo procurar, muito além, em outros países mais quentes, águas de lagos sempre azuis!

Voavam tão alto, tão alto no céu, que o patinho se ficou a olhar para eles embevecido!

Depois, voltando daquele encanto, girou, rodopiando, em torno de si, estendeu o pescoço para os viajantes, e deixou escapar da garganta um grito tão agudo com o qual ele próprio se assustou!...

Ai, que lindas aves!

Nunca mais as esqueceria.

Logo que as perdeu de vista, deu um grande mergulho... Quando retornou à superfície, sentiu-se outro, inteiramente outro.

Não sabia como elas se chamavam, nem para onde iam; mas já as amava como nunca amara a ninguém! 
Não as invejava, não! Não se devem invejar coisas tão perfeitas! Contentar-se-ia, apenas, para ser feliz, que elas o levassem em sua companhia.

O inverno tornava-se de dia a dia mais rigoroso.

O patinho, para impedir que a água gelasse inteiramente, nadava desde manhã à tarde. Mas, à noite, o espaço líquido fechava-se cada vez mais, diminuindo sensivelmente! Era tão forte e rápida a cristalização da água pelo frio, que se ouviam os estalidos do gelo ao solidificar-se!

O patinho era, por isso, forçado a mover as pernas constantemente, para que as paredes frias que limitavam o pequeno espaço onde ainda nadava não se unissem de vez.

Mas ele não contava com a fadiga, a fadiga o venceu.

Sem mais conseguir mover-se, o gelo o prendeu, afinal, e o comprimiu!

No dia seguinte, logo de manhãzinha, apareceu, porém, à margem do tanque, um camponês que o surpreendeu quase gelado.

Caminhou para ele, quebrou o gelo que quase o esmagava, tomou-o nas mãos, e envolvendo-o na jaqueta, quente ainda do calor do seu corpo, levou-o para casa para o dar à mulher.

Ali ao calor suave do fogo, seu sangue recomeçou pouco a pouco a circular, e voltou-lhe de novo a vida!

Os filhos do camponês tentaram, então, divertir-se com ele.

Mas o infeliz, cuidando que o queriam bater, meteu-se depressa entre as latas do leite; dali pulou para a barrica de farinha de trigo, de onde se atirou de novo ao chão, fugindo a toda a força das pernas!

Oh! Deus! Que ruído! Que espetáculo!

A mulher do camponês, empunhando um pau, voou para cima dele, perseguindo-o; as crianças caíram no monte de estrume, ao procurar agarrá-lo, e riam e soltavam gritos...

A sua felicidade foi encontrar aberto o portão da quinta, por onde saiu como um raio, a escorregar na neve que tapetava o chão!

Mas seria um nunca acabar, se fôssemos desfiar o rosário de sofrimentos e de miséria porque passou o desgraçado patinho durante aquele rigoroso inverno.

Uma certa manhã estava ele deitado na umidade fria das margens do lago, entre os juncos, quando reapareceu no horizonte um sol brilhante e quente.

Era o primeiro sorriso da Primavera!

As toutinegras ensaiaram, então, os seus lindos cantos. As borboletas e as abelhinhas trabaIhadoras voaram pelos prados em busca das flores mais perfumadas.

O céu ostentava-se de um azul puríssimo. infortúnio.

As asas do patinho, sem ele o perceber, haviam também crescido nos duros tempos do seu

Eram como uma riqueza compensadora que Deus the mandara!

Assim, já podia voar com vigor e desembaraço. Sentia-o ele. Julgava-se já capaz de fazer longas viagens pelo espaço azulado, como aquelas outras lindas aves que tanto o encantaram!

Um dia, despedindo-se destes lugares que só lhe recordavam amarguras, abriu as asas num primeiro ensaio, e atirou-se no espaço...

Voou, voou, voou.

Lá de cima avistou um grande e belo jardim, onde as macieiras se ostentavam cobertas de flores e os espinheiros se inclinavam, docemente perfumados, a beijar as águas cristalinas de um grande lago...

Desceu encantado e pousou bem junto às águas!

Como tudo era lindo naquele lugar!

Ali, sim, é que a primavera se mostrava em todo o seu rico esplendor!

De repente, de sob a ramaria dos espinheiros surgiam cinco cisnes majestosos e brancos como a neve!

Nadavam alegres, avançando para o seu lado...

O patinho ficou estupefato. Mas, ele os conhecia... Ah! sim, eram lindas aves que tanto o encantaram, quando ainda morava à beira do tanque.

Embora triste, tomou uma resolução.

- Oh! irei ao seu encontro! Quero sentir de perto o roçar das penas de tão soberbas aves! Que me importa que depois me matem pela ousadia! É preferível morrer aos golpes dos seus bicos cor-de-rosa do que viver aos maus tratos dos patos velhos, e das galinhas, e dos pés da criada, e do frio do inverno!

E atirou-se às águas, tomando o rumo dos espinheiros!

Os cisnes, ao perceberem-no, avançaram para o seu lado com as penas eriçadas e o pescoço estendido... 
- Matai-me! pediu-Ihes miseravelmente o pobre patinho.

E abaixando a cabeça, resignado, esperou a morte.

Mas céus, que é que ele via a refletir no espelho das águas!... A imagem de um cisne!

Ele era, então, também um cisne? Já não era, pois, aquele patinho cinzento, disforme, desgracioso, para o qual todos olhavam com desprezo?

Ah! agora tudo ia mudar!

Que lhe importava haver nascido em um ninho de pata, se o ovo que o tinha gerado fora o de um cisne! e o seu coração pôs-se a bater alegremente, esquecendo todos os sofrimentos passados.

Pela primeira vez gozava a plena felicidade, vendo-se cercado de tanta magnificência, e acariciado por bicos de cisnes que eram seus irmãos!

Algumas crianças chegaram ao jardim e puseram-se a atirar à água migalhinhas de pão.

A menor delas, batendo as mãozinhas, exclamou alegre:

- Mas reparem! Ali está mais um cisne!

Os irmãos, logo que o verificaram, começaram a dançar à margem do lago, dizendo:

- Sim, sim, é verdade, ali está mais um cisne!

Depois correram a levar a notícia a seus pais, em cuja companhia regressaram ao lago, a fim de atirar às lindas aves pedacinhos de pão-de-ló!

- E o novo é o mais lindo! Vejam como é elegante!

Os velhos cisnes também assim o julgavam, e passaram vagarosamente pela sua frente, inclinando-se em sinal de respeito!

O novo cisne sentia-se acanhado com tantos elogios! Escondeu a cabeça em baixo de uma asa, por não saber o que havia de fazer.

Mas não o dominava a vaidade.

Um bom coração não se deixa nunca levar por esse feio sentimento. dores!

Ele comparava, apenas, as duas fases da sua vida, julgando-se pago de todas as passadas

Ontem, tão infeliz, desprezado, perseguido e maltratado.

Hoje, até os cisnes saudavam-no com a maior admiração!

Estava, pois, radiante de felicidade.

Além disso, os espinheiros em flor inclinavam sobre ele os seus floridos ramos, e o sol o aquecia com a sua luz bendita!

De tanto gozo, suas penas arrepiaram-se; seu pescoço aprumou-se elegantemente, e ele disse de si para consigo:

— Como poderia eu sonhar tanta felicidade! eu, que era tão feio!

\section{Análise}

Conto exemplar, que no contexto da ideologia romântica tradicional, faz uma clara crítica aos preconceitos sociais, baseados nas aparências e não na essência dos seres e das coisas.

Há uma forte reação do meio ao diferente. O patinho sofre agressões e humiIhações por parte de todos, até mesmo da própria mãe. O preconceito o leva a fugir do convívio de sua família em busca de identidade, reagindo dessa forma à discriminação imposta. 
Sintonizado com a realidade que o cercava, Andersen buscou na literatura uma forma de amenizar o sofrimento das pessoas que passam por situações semeIhantes, como nos aponta Nelly Novaes Coelho ${ }^{103}$ :

\begin{abstract}
A julgar pela visão de mundo patente na história, pode-se imaginar que em certo momento, Andersen, o contador de histórias, tocado pela idéia de que a essência do ser, a potencialidade ou as qualidades intrínsecas do indivíduo são muito mais importantes do que sua aparência física ou sua classe social, Andersen inventa uma situação simbólica que, atraindo a atenção das crianças e divertindo-as, lhes ensinasse essa grande lição de vida.
\end{abstract}

\title{
Proposta Pedagógica
}

Ler a história para os alunos, se possível na íntegra. Após a leitura, dependendo da faixa etária dos alunos, formar um círculo e dialogar sobre o personagem da história. O Patinho era mesmo feio ou era diferente? O que é ser feio e o que é ser bonito? Ele continuou sendo visto como feio para sempre? O que mudou na visão dos outros? Qual a diferença entre pato e cisne? Alguém já viu um cisne? Mesmo discriminado, o Patinho não desanimou, continuou buscando sua identidade. $\mathrm{O}$ que é mais importante: ser ou parecer? O patinho conquistou seu espaço e sua liberdade, mas para isso lutou bastante. Vocês conhecem pessoas que sofreram discriminação e venceram na vida? Nomear essas pessoas e, se possível, fazer um painel com a história dessas pessoas.

${ }^{103}$ COELHO. 2002, op. cit., p.65. 


\subsection{LITERATURA INFANTIL NO CONTEXTO TRADICIONAL}

Paulina pega-fogo, apud João Felpudo, Heinrich Hoffmann, Trad. Guilherme de

\section{Almeida}

Dado biográfico: Heinrich Hoffmann, médico alemão, escreveu Struwwelpeter em 1844, porque não tinha encontrado o presente de Natal adequado para seu filho de três anos.

Estão em casa, sozinhos,

Paulina e seus dois gatinhos.

Paulina é um tanto levada.

Brincou muito e, enfim, cansada,

Sem ter mais com que brincar,

Do que é que se foi lembrar?

Vendo uns fósforos na mesa,

Disse: - Que bom! Que surpresa!

Vamos ter um novo jogo!

Diz o gatinho a Paulina.

- Deixe os fósforos, menina!

Paulina desobedeceu.

Risca um.... dois... A chama desce

$E$ o vestido se incendeia.

Paulina grita, esperneia,

E quanto mais ela tenta

Correr, mais o fogo aumenta!

Que triste história foi esta!

De Paulina eis o que resta:

Uma gatinha chorando,

Um gatinho soluçando,

Dois sapatinhos no chão,

Uma fumaça e um carvão!

\section{Análise}

Faz parte de dez breves contos do livro João Felpudo de Heinrich Hoffmann, em torno dos dez principais defeitos ou erros das crianças: João Felpudo, Alfredo Malvado, Paulina pega-fogo, O Negrinho, O caçador e o coelho, O chupa-dedo, Paulito Palito, Tonico balança-e-cai, O cheira céu, Alberto, o voador . 
No texto analisado, fica estabelecida somente uma única verdade (do ponto de vista do adulto): mexer com fogo é perigoso - o que é verdadeiro. Todavia, não explora a oportunidade de como lidar com o fogo com segurança. O texto é construído de forma a reduzir ou esvaziar qualquer discussão que se possa abrir sobre o comportamento da menina: como, por exemplo, a curiosidade pelo brilho e movimento do fogo, que tanto atrai a criança. Se era levada, mereceu o pior desfecho.

A obediência é tratada como bem supremo. A autoridade do adulto está personificada na fala do gato - como animal que tem instinto, ele pressente o perigo. Paulina desobedece e recebe o castigo maior: a morte. É um texto inibidor da atividade lúdica da criança, da coragem e da criatividade. Não há espaço para o diálogo, para a imaginação e fantasia, próprios do universo infantil. É hermeticamente fechado a qualquer outra possibilidade de novas descobertas.

A narrativa está estruturada na forma de poema, com predominância de rimas para atrair a atenção da criança, pois a cadência e o ritmo da narrativa impedem a dispersão do leitor.

\section{Proposta Pedagógica}

Ler a história uma ou mais vezes. Dar espaço para que os alunos se expressem sobre o que mais chamou sua atenção.

Pesquisar inicialmente possíveis experiências das crianças com fogo: quem daqui gosta de brincar com fogo? Alguém já se queimou alguma vez? Vocês acham o fogo bonito? O fogo é perigoso? Que coisas boas o fogo pode nos trazer?

A seguir, dialogar com os alunos sobre o comportamento de Paulina: ela sabia do perigo? Por que foi brincar com fogo? Por que estava sozinha em casa? Por que quando corria o fogo aumentava? Que idade tinha Paulina? Há casos seme- 
Ihantes ainda hoje? Por quê? É perigoso criança ficar sozinha? É perigoso brincar com fogo? O fogo só faz estragos? Quem trabalha com fogo?

O que faz um bombeiro? É uma profissão importante? Por quê?

Entrevistar profissionais que lidam com fogo, ler notícias sobre acidentes com fogo conversar sobre elas, escrever sobre elas, buscar explicações sobre esse assunto., oportuniza o trabalho interdisciplinar.

\section{O Burrinho Verde}

Maria Thereza Cunha de Giácomo, ilustrações Hilda Bennett

Dado biográfico: Maria Thereza Cunha de Giácomo nasceu em 1932, no Rio de Janeiro. Professora, poeta, tradutora e escritora de livros para crianças foi ganhadora do prêmio Jabuti.

D. Mimosa era uma burrinha muito trabalhadeira e cuidadosa. Todos os vizinhos a estimavam muito, porque sempre estava pronta a ajudá-los no que podia.

De manhã à noite era vista a trabalhar. E com tanto capricho cuidava de sua casa que nunca se via por lá uma poeirinha nas janelas ou um capinzinho pelo chão.

Perto da casa havia um grande pasto muito viçoso, que ela mesma tinha plantado e rodeado com uma bonita cerca de bambu. Era ali que iam brincar os seus filhinhos, de que muito se orgulhava, porque na verdade eram lindos e bem educadinhos.

O mais velho se chamava Chocolate e tinha o pêlo marrom. Todos os dias, depois do banho, a mãe lhe amarrava no pescoço um laçarote de fita amarela e então ia ele brincar no pasto com os seus amiguinhos.

O filhinho que nascera depois de Chocolate havia recebido o nome de Nevado, porque o seu pêlo era branquinho como a neve. Depois do banho a mãe lhe amarrava no pescoço um laçarote de fita verde e também ele ia brincar no pasto com os seus amiguinhos.

O filhinho mais moço era o grande desgosto na vida de D. Mimosa. Por um acaso que nunca se tinha visto no mundo, o caçulinha de $\mathrm{D}$. Mimosa nascera com o pêlo verde.

Por isso a mãe achou difícil escolher o nome que lhe devia dar. Todos só o chamavam de Burrinho Verde. Depois do banho, D. Mimosa Ihe amarrava no pescoço um laçarote de fita vermelha. E também ele lá se ia ao pasto. Mas, por causa de sua cor, ninguém lhe dava atenção.

Todos os bichos da vizinhança deixavam seus filhinhos brincar no pasto de D. Mimosa. Isso porque o Chocolate, o Nevado e o Burrinho Verde eram obedientes e bem comportados. Sabiam brincadeiras alegres, divertiam-se, mas nunca faziam travessuras. O cabrito Bé-Bé, o coelhinho Pompom, o leitão Duchinho, entre outros, eram sempre vistos a brincar de saltos e de corridas com o Chocolate e o Nevado.

Mas, quando chegava o Burrinho Verde, o coelhinho Pompom logo ia dizendo: - Burro verde não existe no mundo, logo você não existe. $E$ por isso não podemos brincar com você!

- É isso mesmo, gritava o cabrito Bé-Bé. Ou esse Burrinho Verde pinta o pêlo de branco, ou então não brincamos com ele!

- Primeiro ele tem de pintar o pêlo de branco, dizia, também, o Duchinho.

E então todos começavam a rir e caçoavam do pobrezinho. 
O Burrinho Verde ia para perto da cerca de bambu e ali chorava em silêncio a sua pouca sorte. Mas ninguém queria saber de suas lágrimas. Ainda mais porque também as lágrimas do coitado eram verdes e, por isso, podiam manchar o lenço de quem quisesse enxugá-las.

Só a mãe compreendia a tristeza do caçulinha e fazia tudo para encorajá-lo. Tinha ela grandes esperanças de que a cor verde haveria de mudar com as lavagens e as esfregadas que the aplicava todos os dias com sabonete e muita água.

Mas, ao contrário do que esperava, a cor verde ficava cada vez mais carregada! Parecia o colorido da relva nesses dias bonitos da primavera quando não há nuvens no céu e o sol brilha forte.

O Burrinho Verde esperava pacientemente. E, vendo a mãe tão desgostosa, até procurava consolá-la, dizendo:

— Um dia ainda serei muito feliz, mamãe. Não fique triste!

Quando os três filhos de D. Mimosa ficaram mais crescidinhos resolveram empregar-se para ajudar a mãe.

O Chocolate foi trabalhar nas terras de um camponês, puxando o arado durante o dia todo. E, quando à noite voltava para casa, contava as novidades que via por lá.

Os filhos do camponês eram bem travessos e muitas vezes maltratavam o Chocolate. Mas ele nada dizia à mãe, para não entristecê-la.

Certo dia, o Chocolate salvou da morte a rãzinha Pepita, que ia sendo esmagada pelas pesadas rodas do arado. Desde então ambos ficaram muito amigos. E, para se mostrar agradecida, a Pepita ensinou ao Chocolate o lugar onde havia uma fonte de água fresquinha e gostosa, que ele ia beber sempre que acabava o trabalho.

D. Mimosa sorria contente ao ouvir todas aquelas novidades e ao ver o filho voltar alegre para casa.

O Nevado havia encontrado emprego na casa do leiteiro. De manhã cedinho antes de nascer o sol, lá ia ele puxar a carrocinha cheia de garrafas de leite. Para chamar a freguesia, quando passava pelas ruas, o leiteiro lhe havia pendurado no pescoço um bonito chocalho dourado. Todas as crianças, quando ouviam os sons daquele chocalho, vinham correndo para rodear o Nevado e fazer-lhe festas.

- Sabe, mamãe, dizia ele muito orgulhoso, estou gostando bastante do meu trabalho. Ainda mais porque o meu patrão me faz andar com um chocalho de som tão lindo que até me dá vontade de dançar!...

Só o coitado do Burrinho Verde continuava sem sorte. Ninguém queria aceitá-lo como empregado, porque estranhavam aquela cor tão esquisita para um burrinho.

- Desculpe-me, D. Mimosa, foi dizendo logo o padeiro, quando a mãe foi oferecer o caçulinha como ajudante de forno. Que diriam os fregueses se a cor dele manchasse a massa do pão?

Também o tintureiro não o quis como empregado. Nem mesmo para puxar a carrocinha de entrega de roupas, porque achava que todos iriam fazer caçoada dele.

Desanimado e triste o Burrinho Verde voltava para casa. Queria tanto trabalhar! Achava muito triste ficar sem ocupação, como coisa sem utilidade.

Mas, como não queria ficar sem fazer nada, ajudava a mãe. Dava recados, entregava encomenda aos vizinhos, varria a casa, limpava o pasto. Às vezes, até levava um bichinho qualquer a passear, montado no seu lombo, só para mostrar aos outros que estava trabalhando.

Certo dia, D. Mimosa deu pela falta do caçulinha. Ficou preocupada e pôs-se a procurá-lo por todos os lados. Mas, qual! Não o achava em parte alguma. Muito nervosa, pediu então às vizinhas que a ajudassem a encontrar seu filhinho.

As vizinhas, porém, desculparam-se com os seus trabalhos e mesmo não tinham lá muita vontade de se preocupar com aquele burrinho esquisito.

- Ora, D. Mimosa, diziam elas, que falta Ihe poderá fazer o Burrinho Verde? A senhora até devia estar contente por ele ter desaparecido.

Mas D. Mimosa não queria conformar-se com a perda do seu caçulinha.

- Verde ou não, ele é meu filho! Não descansarei enquanto não o tiver encontrado! respondeu ela, com firmeza.

E continuou a procurar o dia inteiro pelos campos e morros próximos. Foi à casa do coelhinho Pompom, ao chiqueiro do Duchinho e também falou com o cabrito Bé-Bé. Mas todos lhe davam a mesma resposta:

— Não, D. Mimosa, não vimos o Burrinho Verde.

Ao cair da noite, D. Mimosa ficou desesperada e começou a chorar. Em vão procurou enxugar as lágrimas que não paravam de rolar de seus grandes olhos aveludados. E cansada de esperar, já ia fechar a casa, quando de repente se abriu a porta e o Burrinho Verde entrou todo risonho e satisfeito. 
D. Mimosa não coube em si de contentamento. Enfim, tinha outra vez o seu caçulinha! Mas, embora tão contente, achou que devia ralhar um pouco com ele.

- Onde esteve esse tempo, meu filho? Você pregou um grande susto em sua mãe. Isso não se faz! Eu estou muito zangada com você!...

Mas o Burrinho Verde nem parecia ter ouvido as palavras de D. Mimosa. E, correndo para junto dela, exclamou:

- Pronto, mamãe! Já arranjei um emprego! Afinal, consegui vencer! Amanhã à noite vou começar a trabalhar!

A princípio $\mathrm{D}$. Mimosa pensou que aquilo fosse brincadeira do caçulinha, pois a coitada já havia perdido toda a esperança de arranjar emprego para ele. Mas sentia-se feliz por tê-lo outra vez junto de si. Por isso deu-lhe um beijo muito carinhoso e disse:

- Você está brincando, meu filho, já sei!

Mas o Burrinho Verde não estava brincando. E tanto é que logo na manhã seguinte foi recomendando à mãe:

— Escove hoje bem o seu pêlo, mãezinha, e ponha sua fita prateada no pescoço. Quero vê-la muito lustrosa e bonita! Você me vai ver trabalhar esta noite!

D. Mimosa então achou melhor acreditar.

Enquanto ela se aprontava com o Chocolate e o Nevado, o Burrinho Verde foi tomar um banho demorado. E tão entusiasmado estava que depois chegou a pedir à mãe que the amarrasse no pescoço um laçarote de fita verde!

D. Mimosa ficara muito curioso por saber qual era o emprego que o caçulinha tinha arranjado. Mas a todas as suas perguntas ele só respondia com um sorriso...

Ao cair da noite, os quatro saíram de casa: a mãe, o Chocolate, o Nevado e o Burrinho Verde, que ia à frente.

D. Mimosa ficou admirada quando viu o lugar onde iria trabalhar o seu caçulinha. Era um pasto enorme onde se erguia um alto cercado de lona cinzenta e no interior do qual havia uma porção de cadeirinhas e arquibancadas de pau. Uma multidão de gente e de bichos ali estava, esperando.

Pouco depois chegavam também o porquinho Duchinho, o coelhinho Pompom e o cabrito BéBé. Numa cadeirinha alta, subiu a rãzinha Pepita. Ela olhava tudo, com seus olhinhos arregalados. Numa tabuleta enfeitada de flores e pregada à entrada do cercado, podia-se ler em grandes letras:

\section{CIRCO JUJU}

O caso é que o Burrinho Verde ia trabalhar num circo!

Drim-drim, drim-drim! Ouviu-se, de repente, soar uma sineta. Era o sinal para o começo do espetáculo! Toda a assistência ficou quietinha e olhou com atenção para o centro do circo.

Três palhaços fizeram rir o público com os seus gracejos e piruetas. Um homenzinho andou de bicicleta sobre uma corda com um macaquinho ao colo. E, depois, apareceu um velhote gorducho e anunciou em voz alta:

- Senhores e senhoras, esta noite tenho o prazer de lhes apresentar o Burrinho Verde e a Bailarina Cor-de-Rosa, únicos no mundo inteiro! Eles irão representar um número especial que com certeza há de agradar a todos.

Logo em seguida entrou galopando o caçulinha de D. Mimosa. Trazia arreios dourados, e de pé sobre o seu lombo, na sela de cetim azul, estava uma jovem bailarina. Era a Bailarina Cor-deRosa, que começou a executar toda sorte de arriscadas acrobacias, enquanto o Burrinho Verde trotava cada vez mais depressa.

Toda a assistência aplaudiu com grande entusiasmo quando a Bailarina Cor-de-Rosa e o caçulinha de $\mathrm{D}$. Mimosa acabaram de representar o seu número.

E, entre vivas e palmas, o Burrinho Verde todas as noites mostrava no Circo Juju as habilidades que ia aprendendo. E tão bem se comportou no seu emprego que em breve se tornou o burrinho mais querido e famoso de toda aquela redondeza.

D. Mimosa ficou tão contente com o sucesso de seu caçulinha que até quis pintar o Nevado e o Chocolate de verde. Mas depois achou melhor deixá-los como eram.

E o Burrinho Verde nunca mais se queixou de haver nascido com aquela cor esquisita, pois fora ela que o ajudara a vencer na vida. 


\section{Análise}

Burrinho Verde é rejeitado por ser diferente, nasceu verde nesta história. O trabalho no circo é focalizado mais como utilidade do que como realização do ser. Há a valorização da obediência e do bom comportamento.

Ao Burrinho Verde é negada a identidade: "Burro Verde não existe, logo você não existe". Com isso Burrinho Verde ficava muito triste e "... chorava em silêncio sua pouca sorte". Ser legitimado pela coletividade é uma necessidade inerente da pessoa.

Trata-se de um pequeno romance, pois se desdobra em episódios, que se finalizam na nova experiência do Burrinho Verde trabalhando no circo. Foi na Arte que ele encontrou seu lugar.

\section{Proposta Pedagógica}

Ler a história para e com os alunos. Abrir espaço para que manifestem suas impressões e compreensões da história.

Dialogar com os alunos sobre a questão das diferenças que existem na sociedade. Diferenças físicas, étnicas, culturais, econômicas, profissionais, sociais, entre outras. Explorar a experiência das crianças com deficientes. .Quem conhece um deficiente? Qual é a deficiência dele? Você brinca com algum deficiente? Há algum deficiente em sua família? Como você se comporta quando encontra um cego esperando para atravessar a rua? As pessoas deficientes conseguem trabalho? Há espaço no mercado de trabalho para elas? As pessoas deficientes passeiam? Nos locais públicos como: estação do Metrô, nas calçadas, nos ônibus, nos estacionamentos, há recursos para os deficientes? Quais? Você já viu? 
Se possível, trazer um deficiente à escola para falar de sua experiência de vida sobre o que um deficiente pode fazer.

\section{NHÁ DITA CONTOU}

\section{Odete de Barros Mott}

Dado biográfico: nasceu em 1913, em Igarapava-SP. Professora e mãe foi como contadora de histórias para seus oito filhos que descobriu sua vocação como escritora de livros para crianças e jovens.

\section{Capítulo I*}

Nhá Dita, preta gorda, simpática e serviçal, é verdureira. Viúva, tem um filho de dez anos, Ditinho, menino vivo, estudioso e bom. Todos os dias, ele vai à escola pobremente vestido, porém limpo e arrumado.

Moram os dois numa casinha cercada de árvores frutíferas, de trepadeiras. Porém, o que mais encanta aos que visitam a chacarazinha, é a horta.

- Que horta linda!

- Como as verduras vicejam e crescem!

- São cuidadas por mãos de fadas, dizem.

Nhá Dita tem seu segredo: ela ama a terra e a trata com carinho.

Ali, pois, um pouco retirados da cidade, vivem os dois felizes. Contudo Ditinho traz um desgosto escondido, que nunca contou a ninguém: Queria ser branco!

Certo dia, estava ele muito contente, jogando pião durante o recreio, quando ao seu lado, foram conversar três colegas.

- Fui o primeiro este mês, diz Fábio.

- Que nota tiveste? Perguntou-Ihe Sérgio.

- Oito.

- Foi esta a nota mais alta da classe?.Parece-me que a professora falou um nove.

- Tive nove, disse Ditinho, parando de jogar pião. Neste caso, sou o primeiro.

— Ah! Ah! Ah!... Fabinho desandou a rir. Um risinho de caçoada.

- Por que te ris assim?.Não acreditas? Pois vê só minhas notas. Aqui está minha caderneta.

- Não precisas mostrá-la, não. Acredito sim. Porém, continuo a pensar que sou o primeiro.

Todos os olhos o fitam, procurando uma explicação. Nenhum dos garotos podia compreender aquela complicação. Ter nota mais baixa e ser o primeiro... Pela lei, o primeiro seria Ditinho que tivera nove.

- Não entendo, explica-te, propôs Régis.

- Ora, é fácil. Ditinho é preto, e preto não é gente. Por isto, não se conta.

Ditinho sente o sangue fugir-lhe da cabeça, do rosto, e parar o coração, apertando-o. Quer chorar, porém, ali estão os colegas a fitarem-no, atentos. Abaixa-se e finge enrolar o pião. Nada responde.

Fabinho, indiferente, continua a conversar. Seus amigos, porém, não estão contentes. Gostam de Ditinho, acham que ele é bom colega, educado, leal. Reparte os bolinhos fritos que leva para o lanche, ensina as lições aos mais atrasados. Nunca, mas nunca mesmo colou...

- Ditinho, propõe Luiz Alberto, para distrair o colega, vamos jogar uma partida? Garanto-lhe que rodo pião na unha.

- De verdade? Pergunta o pretinho, sem levantar os olhos, pois sentia as lágrimas prontas para rolarem.

\footnotetext{
*Transcrevemos somente o capítulo I do livro, dada a extensão da história.
} 
- Sim. Queres ver?

- Ora, deixa de ser prosa, diz sorrindo Marcos.

Uma rodinha formou-se em torno do pretinho. Os colegas procuravam deste modo, mostrarIhe suas simpatias.

Logo a sineta tocou. Ainda tiveram aulas. Apesar de sentir-se estimado, Ditinho, à tarde, voltou para casa aborrecido.

Sua mãe logo notou.

- Que tens, meu filho?

- Nada, não senhora.

- Tens sim. Alguma coisa te preocupa.

- Nada, mamãe.

- Ora, meu filho, não sabes que a mãe é a melhor amiga que temos?

O garoto, então, contou tudo o que se passara na escola. Dona Dita ficou triste; gostava muito do filho, e não queria vê-lo humilhado.

Há muito vinha notando aquele sentimento que o menino guardava no coração. Não queria que seu filho continuasse a achar um mal em ser preto. Nem que se julgasse inferior.

Entre um preto e um branco, pensava ela, há simplesmente a diferença da cor. Precisava, pois dar um jeito.

\section{Análise}

O texto é de um humanismo ingênuo que reproduz o preconceito. Já ao apresentar os personagens Nhá Dita e Ditinho, a autora já os caracteriza de maneira estereotipada: apresenta Nhá Dita como "preta gorda", (o mesmo que deselegante); e refere-se a Ditinho como preto, porém, limpo: "Todos os dias vai à escola pobremente vestido, porém limpo e arrumado". O preconceito e a discriminação são evidentes na frase: "Ditinho é preto e preto não é gente". Essa atitude o faz sentir-se triste e desejar ser branco. Necessita ser legitimado como negro. A autora ao tentar minimizar as injustiças com bondade e solidariedade, retrata um humanismo ingênuo, embora no decorrer da narrativa Nhá Dita tenha se preocupado com a questão racial, quando convidou os amigos de Ditinho para Ihes narrar a vida do santo negro Martinho.

\section{Proposta Pedagógica}

Ler a história em partes, de acordo com a disponibilidade de tempo para essa atividade. Ao final pedir aos alunos que recontem a história oralmente ou por escrita. Indagar se alguém já ouviu dizer ou assistiu a situações parecidas 
Dialogar com os alunos sobre o conto: o que sentiram? De quem vocês mais gostaram nessa história? O que pensam sobre os colegas de Ditinho? Vocês gostariam de ser igual a Ditinho ou a seus colegas? Por quê?

Pontuar a questão do preconceito em relação às etnias e propor uma visão cultural mais ampla que vá além do próprio lugar onde se vive. Discutir sobre valores éticos, humanos e sociais que possibilitam a abertura para novos horizontes e despertam para uma visão de mundo mais justa e humana.

Fazer com as crianças uma pesquisa que relacione pessoas negras que se destacam ou se destacaram na política, nas artes, na música, em práticas sociais, esportes e outros mais. Elencar o nome dessas pessoas e o que fizeram, em painel, e afixá-lo na sala. Exemplo: Zumbi dos Palmares, Teodoro Sampaio, $1^{\circ}$ engenheiro negro formado; Prof. Nilton Santos pesquisador; e outros como Milton Nascimento, Ademar Ferreira da Silva, Nelson Mandela.

\subsection{LITERATURA INFANTIL NO CONTEXTO CONTEMPORÂNEO}

\section{O reizinho mandão}

Ruth Rocha, ilustrações Walter Ono

Dado biográfico: Ruth Machado Lousada Rocha nasceu em São Paulo, no ano de 1931. É bacharel em Ciências Políticas e Sociais e licenciada em Ciências Sociais. É uma das autoras brasileiras mais atuantes na Literatura Infantil.

Ruth Rocha está entre os escritores e escritoras que, nos anos 70 , encontraram novas propostas e caminhos para a renovação da literatura para crianças e se empenharam numa produção que hoje é conhecida como responsável pelo boom da literatura infantil brasileira dos anos70/80. Suas primeiras estórias forma publicadas em revistas nacionais e estrangeiras. ${ }^{104}$

${ }^{104}$ COELHO. 1995, op.cit., p.998. 
Quando Deus enganar gente,

Passarinho não voar...

A viola não tocar,

Quando o atrás for na frente,

No dia que o mar secar,

Quando prego for martelo,

Quando cobra usar chinelo,

Cantador vai se calar...

Eu vou contar pra vocês uma história que o meu avô sempre contava.

Ele dizia que essa história aconteceu há muitos e muitos anos, num lugar muito longe daqui.

Nesse lugar tinha um rei, daqueles que têm nas histórias.

Da barba branca batendo no peito, da capa vermelha batendo no pé.

Como esse rei

era rei de história, era um rei muito bonzinho, muito justo...

E tudo o que ele fazia era pro bem do povo.

Vai que esse morreu, porque era muito velhinho, e o príncipe, filho do rei, virou rei daquele lugar.

O príncipe era um sujeitinho muito mal-educado, mimado, destes que as mães deles fazem todas as vontades, e eles ficam pensando que são os donos do mundo.

Eu tenho uma porção de amigos assim.

Querem mandar nas brincadeiras...

Querem que a gente faça tudo o que eles gostam...

Quando a gente quer brincar

de outra coisa,

ficam logo zangados.

Vão logo dizendo:

"Não brinco mais!"

E quando as mães deles vêm ver o que aconteceu, se atiram no chão e ficam roxinhos, esperneiam e tudo.

Então as mães deles ficam achando que a gente está maltratando o filhinho delas.

Então, como eu estava contando, o tal do príncipe ficou sendo o rei daquele país.

Precisa ver que reizinho chato que ele ficou! 
Mandão, teimoso, implicante, xereta!

Ele era tão xereta, tão mandão, que queria mandar em tudo o que acontecia no reino.

Quando eu digo tudo, era tudo mesmo!

A diversão do reizinho era fazer leis e mais leis.

$E$ as leis que ele fazia eram as mais absurdas do mundo.

Olhem só esta lei:

"Fica terminantemente proibido cortar a unha do dedão do pé direito em noite de lua cheia!"

Agora, por que é que o reizinho queria mandar no dedão das pessoas, isso ninguém jamais vai saber.

Outra lei que ele fez:

"É proibido dormir de gorro

na primeira quarta-feira do mês".

Agora, por que é que ele inventou essas tolices, isso ninguém sabia.

Eu tenho a impressão de que era mesmo mania de mandar em tudo.

Os conselheiros do rei ficavam desesperados, tentavam dar conselhos a ele, que afinal é pra isso que os conselheiros existem.

Eles explicavam que um rei tem de fazer leis importantes, para tornar o povo mais feliz.

Mas o reizinho não queria saber de nada.

Era só um conselheiro qualquer abrir a boca para dar um conselho, e ele ficava vermelhinho de raiva, batia o pé no chão e gritava de maus modos:

- Cala a boca! Eu é que sou o rei. Eu é que mando!

Podia ser ministro, embaixador, professor.

E tantas vezes ele mandava, que o papagaio dele acabou aprendendo a dizer "Cala a boca" também.

Tinha horas que era até engraçado.

O reizinho gritava "Cala a boca" de cá,

e o papagaio gritava "Cala a boca" de lá.

As pessoas, então, foram ficando

cada vez mais quietas,

cada vez mais caladas.

É que todo mundo tinha medo de levar pito do rei.

E, de tanto ficarem caladas, as pessoas foram esquecendo como é que se falava. 
Até que chegou um dia em que o reizinho percebeu que ninguém mais no reino sabia falar.

Ninguém!

No começo até que ele gostou, porque podia falar durante horas e horas e ninguém interrompia.

Só o papagaio é que de vez em quando se enchia da falação e gritava:

- Cala a boca! Cala a boca!

O reizinho nem ligava

e continuava falando, falando...

Mas tudo o que a gente faz sozinho acaba cansando.

E o reizinho começou a enjoar de tanto falar sozinho.

E tentava convencer as pessoas a conversar com ele.

Vinha assim, como quem não quer nada, e puxava conversa, perguntava uma coisa e outra.

Mas as pessoas não respondiam nada!

Ele aí foi ficando louco da vida, gritava com as pessoas, xingava, chamava os guardas para prender todo mundo.

Mas ninguém dizia nada.

Não é que as pessoas não quisessem falar.

Elas não sabiam mais falar, mesmo!

Nem os conselheiros podiam dar o menor conselho.

Eles não sabiam mais como!...

E o reizinho foi percebendo, devagar, o que ele tinha feito com seu povo.

Aí, deu nele uma coisa no coração, uma tristeza, uma dor na consciência...

Então ele resolveu dar um jeito na situação, descobrir uma forma de consertar o estrago que tinha feito.

Resolveu visitar o reino vizinho, onde - ele tinha ouvido falar, antes que todo mundo calasse a boca havia um grande sábio, capaz de resolver 
problemas do arco da velha.

E quem foi que o reizinho escolheu para ir com ele?

Pois foi o papagaio, que não parava de gritar "Cala a boca", mas que pelo menos era uma companhia.

O reizinho botou o papagaio no ombro, deu uma última olhada no castelo, e saiu para a estrada, em busca do sábio.

O reino do reizinho era meio grande, por isso ele demorou um pouco a chegar.

E teve de atravessar o reino todinho, naquele silêncio de apertar o coração.

Por isso, quando ele atravessou a fronteira e entrou no reino vizinho, até levou um susto!

Era um tal de gente cantando, dançando, conversando...

Tinha criança brincando de roda, tinha menino gritando na rua, tinha até um velho parece que fazendo discurso. $E$ todo mundo vinha conversar com o reizinho e perguntar o que é que ele estava fazendo ali. E ele gostava e ia conversando muito direitinho, sem mandar ninguém calar a boca, nem nada!

Até que ele achou o lugar onde tinha o tal sábio.

Era um velho miudinho, que falava pelos cotovelos.

Se fosse antes de ter acontecido toda essa história, aposto que o reizinho ia logo mandar que ele calasse a boca.

Mas agora o reizinho estava muito diferente!

Até pediu desculpas por estar incomodando...

E quando o sábio interrompia o rei, ele nem ligava, ficava dando umas risadinhas, pra agradar o velho.

Vocês precisavam ver o pito que o velho passou no reizinho!

- Pois é - ele dizia. - Vai mandando calar a boca, não é? Depois agüenta! É isso que dá!

E o velho andava de um lado pro outro, balançava a cabeça e sacudia o dedo, bem no nariz do rei.

E o rei não podia fazer nada, 
que ele não era rei daquele lugar, nem nada, e até estava na casa do sábio...

De repente, o velho sossegou, sentou junto do reizinho e disse:

- Olha aqui, mocinho. Esse negócio de ser rei não é assim, não! Não é só ir mandando pra cá, ir mandando pra lá. Tem que ter juízo, sabedoria.

As coisas que um rei faz

fazem acontecer outras coisas.

Veja só o seu caso: mandou que mandou! Inventou uma porção de leis bobocas.

Mandou todo mundo calar a boca, calar a boca, calar a boca! Decerto, com medo de que todo mundo dissesse que você estava fazendo bobagens.

Pois todo mundo calou!

Não era isso o que você queria?

O reizinho baixou a cabeça desapontado...

- E não adianta emburrar, não! - continuou o velho.

- Agora você tem que dar um jeito nessa situação.

- É isso mesmo que eu quero - falou o reizinho.

- O senhor me diga o que eu devo fazer, que eu faço!

- Pois muito bem! - falou o velho. - O que você tem que fazer é sair pelo seu reino batendo de porta em porta. Se conseguir encontrar uma criança, uma só, que ainda saiba falar, ela vai dizer a você o que você precisa ouvir. E nesse dia seu reino vai ficar livre dessa maldição.

- Mas o que ela vai dizer? perguntou o reizinho, aflito.

- Ah, isso eu não sei - disse o sábio.

- Mas você não é um sábio? Não sabe de tudo?

- Saber, eu sei, de muitas coisas.

Mas isso não. Procure uma criança

que saiba falar. Essa, sim, pode ensinar você.

O reizinho saiu meio desanimado.

Esse negócio de sair assim, sem mais nem menos, batendo de porta em porta, não ia ser fácil!

Mas, que remédio?

Era sua única esperança...

E lá se foi o reizinho, de papagaio no ombro, de volta para o seu reino.

Vocês precisavam ver quanto o reizinho andou! Ele percorreu o reino inteirinho! Batendo de casa em casa, sempre perguntando se as pessoas conheciam uma criança que falasse. 
Mas em todo lugar que o reizinho batia, as pessoas ficavam muito espantadas, com muito medo dele,

e balançavam a cabeça pra lá e pra cá.

Ninguém conhecia a tal criança!

E o silêncio era cada vez maior.

Todo mundo quieto,

esperando que alguma coisa acontecesse...

Até que um dia...

História é bom por causa disso!

Tem sempre uma hora em que quem está contando a história diz:

"Até que um dia..."

Pois até que um dia

o reizinho chegou perto de uma casa

e reparou que, do lado de dentro, estavam fechando as janelas.

Ele aí desconfiou...

Bateu na porta, bateu, bateu.

E ninguém atendia!

Mas o reizinho percebeu que tinha gente em casa.

$\mathrm{E}$ bateu mais e mais.

E começou a gritar:

- Não adianta fingirem que não tem ninguém.

Eu não saio daqui se não abrirem.

Aí a porta da frente foi abrindo, devagarinho, e apareceu uma velha.

O reizinho fez a mesma pergunta que ele fazia em todo lugar:

- Por favor, por favor, minha senhora, nesta casa não existe uma criança que ainda saiba falar?

A velha sacudiu a cabeça, assustadíssima, fazendo sinais para o reizinho ir embora.

E olhava para dentro, amedrontada, como se estivesse escondendo alguma coisa.

O reizinho ficou desconfiadíssimo com a atitude da velha.

Então ele empurrou a porta e foi entrando, 
porque, como eu contei, ele era muito mal-educado

e ia entrando na casa dos outros mesmo sem convite.

Lá no fundo, meio no escuro,

tinha uma menina: magrinha,

de trança comprida e de avental xadrez.

Aí o reizinho foi indo na direção da menina,

parou perto dela e perguntou

com uma vozinha toda macia:

- Então, linda menina!

Não vai me dizer alguma coisa?

A menininha, nada!

- Como é, minha flor? Diga alguma coisa

para o seu rei ouvir! Anda!

A menininha, nada!

Mas o reizinho, que estava muito desconfiado, ficou vermelhinho de raiva e se desmascarou:

- Olhe aqui, minha filha! Eu sou o rei, sabia?

Trate de dizer alguma coisa já, já!

A menininha não disse nada, mas o papagaio, ouvindo a voz antiga do reizinho,

arrepiou-se todo e gritou:

- Cala a boca!

Cala a boca!

Cala a boca!

Quando o papagaio disse isso,

precisava ver a cara da menininha.

Ela ficou vermelhinha também, arregalou uns olhos muito brilhantes

e gritou, com toda a força:

- Cala boca já morreu!

Quem manda na minha boca sou eu!

No mesmo instante ouviu-se um estalo, como se fosse um trovão,

e começou um barulho estranho,

que há muito tempo ninguém escutava.

Eram vozes e mais vozes

que vinham de todos os lados

de perto e de longe.

Fortes e fracas, de homens, de mulheres e de crianças.

Cantando, falando, gritando e rindo!

Eram canções de roda, de amor, de brincadeira...

E música de banda, de fanfarras e de orquestras! 
O reizinho foi ficando assustado, amedrontado, perturbado com todo aquele barulho, com toda aquela alegria.

Tapou os ouvidos com as mãos, mas não adiantou.

O barulhão foi deixando o reizinho apavorado, até que ele não agüentou mais

e saiu correndo pela estrada.

O fim desta história meu avô não sabia.

Uns contam que o reizinho ficou com tanta raiva, com todo mundo dizendo tudo o que pensava, que fugiu pra longe e nunca mais voltou.

Outros dizem que ele desistiu de ser rei e que deixou o lugar pro irmão dele.

E há quem diga que quando o encanto se desfez o reizinho virou sapo e anda por aí pulando, coaxando e esperando que alguma princesa dê um beijo nele e ele vire rei de novo.

Por isso, se você é uma princesa, vê lá, hein! Não vá beijar nenhum sapo por aí... Porque os reizinhos mandões podem aparecer em qualquer lugar!

\section{Análise}

O tema central trata da reação do fraco contra o poder absoluto do forte. É um conto de reação à opressão, à tirania.

Sem perder o encanto, com sua linguagem clara e objetiva, o texto permite dialogar com a realidade atual, levando o leitor a se questionar sobre respeito, dignidade e cidadania.

\section{Proposta Pedagógica}

Ler a história uma ou mais vezes. Fazer levantamento dos assuntos abordados na história: criança mal criada, rei mandão, sábio, liberdade, autoritarismo. Abrir espaço para que os alunos se expressem a respeito. O que vocês mais gostaram nessa história? E o que vocês menos gostaram? 
Solicitar às crianças o exercício de compreensão: acontecem coisas parecidas hoje? Quem sabe contar um caso semelhante? Conhecem alguém parecido com o reizinho mandão? Quem é e como age essa pessoa? O que seria possível fazer no reino do reizinho mandão além de ficar quieto? Por que você acha que as pessoas escolheram ficarem quietas? Vamos escolher outras coisas para fazer além de "ficar quieto" no reino do reizinho mandão? Explorar as propostas apresentadas pelas crianças e construir com elas um texto coletivo a ser escrito no quadro de giz ou branco ou no caderno ou em papel pardo e fixá-lo na sala.

\section{Farra no formigueiro}

\section{Liliana \& Michele lacocca}

Dado biográfico: Liliana nasceu em 1947, no bairro da Moóca. Faleceu em 2005. Foi jornalista e escritora. Seus textos imaginativos e engraçados sempre encantaram o leitor jovem. Casou com Michele lacocca, italiano, residente no Brasil há mais de 30 anos. Michele é formado em Artes Plásticas e foi na década de 70 que começou a ilustrar livros para crianças e jovens. Foram parceiros na criação de livros.

Toda manhã a fila de formiga saía do formigueiro.

Papai e Mamãe Formiga iam na frente. E, enquanto iam andando, iam contando uma história.

A coisa funcionava assim: Papai e Mamãe Formiga contavam a história para a filha mais veIha, que também era a primeira da fila. Ela ia repetindo a história direitinho para a que vinha atrás dela, e a que vinha atrás para a que vinha mais atrás ainda e assim por diante, até chegar na menor de todas, que também era a última da fila.

Naquela manhã tudo estava se repetindo igualzinho aos outros dias.

E, como nos outros dias, Papai e Mamãe Formiga foram logo começando a história: Era uma vez uma formiga...

— Ufa! - falou a mais velha, que também era a primeira da fila. — Outra vez a história da cigarra e da formiga!

- Desde que eu nasci que eu estou ouvindo a mesma história - disse a segunda mais velha que também era a segunda da fila.

- Já sei de cor e salteado esta história - falou a terceira.

E assim por diante, cada uma delas foi dando sua opinião até chegar na menor de todas, que também era a última da fila.

E a menor de todas falou:

- Eu não tenho nada contra a história da cigarra e da formiga. Eu até gosto dela. A única coisa que me incomoda é que só a cigarra canta. Afinal de contas, eu também gosto de cantar.

- Eu também já pensei nisso muitas vezes - falou a penúltima, que também era a penúltima da fila. 
- Cantar sempre foi o meu sonho - falou a antepenúltima.

E assim por diante, cada uma delas foi dando sua opinião até chegar na maior de todas, que era a primeira da fila.

A primeira da fila, sem pensar duas vezes, saiu da fila e começou a cantar:

Ziriguidum...

Ziriguidum... dum... dum... dum...

Eu agora sou cantora

E vou cantar o ano inteiro,

Para o samba balançar

Este formigueiro.

Ziriguidum...

Ziriguidum... dum... dum... dum...

A segunda da fila não perdeu tempo e falou:

- Eu prefiro uma música bem barulhenta. - E pulando e se mexendo toda começou a soltar uns agudos estridentes.

Abrindo a boca o mais que podia, a terceira da fila também começou a cantar, batendo as patas no chão,

E assim por diante.

Teve quem cantou mais alto, mais baixo, com voz esganiçada, com voz fina, com voz grossa, gritando, berrando, cantaram todo tipo de música e de todo jeito que se pode imaginar.

A essas alturas a fila já tinha deixado de ser fila e virado uma tremenda confusão.

- Que tremenda confusão! - falou Papai Formiga, enquanto corria de um lado para o outro, tentando organizar a fila de novo.

- Venha me ajudar aqui! - ele gritou para Mamãe Formiga.

— Já vou... Ziriguidum... já estou indo... Ziriguidum... dum... dum... dum...

\section{Análise}

Conto contemporâneo na linha da desconstrução da fábula tradicional. Aqui, o pequeno tem voz e tem vez. A formiguinha mais nova ousa questionar e transgredir à norma familiar estabelecida.Valorização do lúdico, da arte, da criatividade. O importante é ser, ter liberdade, e prazer. O adulto, na personagem da Mamãe Formiga, adere à nova 'ordem', ao responder ao apelo do marido para ajudá-lo “ a restabelecer a ordem antiga "já estou indo... Ziriguidum", no qual todos eram felizes.

\section{Proposta Pedagógica}

Fazer a leitura da fábula $A$ cigarra e a formiga, de La Fontaine e proceder a exploração dessa fábula junto aos alunos: o que mais gostaram nessa história e o que menos gostaram. O que fariam se estivessem no lugar da cigarra? $\mathrm{E}$ das formigas? Explorar a experiência dos alunos com o tema. Depois, em outra atividade, em outro dia, apresentar a história: Farra no formigueiro. Indagar os alunos: se estives- 
sem na fila das formigas o que eles teriam feito? Dançariam? O que mais gostaram nessa história e o que menos gostaram? Se estivessem no lugar dos pais das formigas o que teriam feito? Estabelecer um diálogo com os alunos sobre ambas histórias. Anotar no quadro de giz ou branco as interpretações das crianças. Agrupar os temas e organizar a classe em pequenos grupos. Cada grupo escolherá um dos temas selecionados.

Colocar para todos os grupos as seguintes questões: o trabalho é necessário para a sobrevivência? O trabalho tem que ser aborrecido ou pode ser prazeroso? $\mathrm{O}$ estudo é um trabalho? O que é preciso para que o trabalho dê prazer e alegria? (Aqui é importante conduzir as reflexões das crianças sobre trabalhar com o que se gosta de fazer, compreender a importância do trabalho que faz para o bem estar das pessoas e o respeito nas relações dentro do grupo de trabalho). O lazer é necessário? Quais são os espaços de lazer de nosso bairro? E na cidade? Existem profissões ligadas ao lazer? As pessoas que trabalham no lazer, precisam também de lazer? Existe espaço de lazer para todas as pessoas que trabalham? As pessoas têm tempo para o lazer? Que tipo de lazer faz bem à saúde?

Sugere-se também dialogar sobre a coragem da pequena formiga, última da fila, em dizer o que pensava e sentia. Ela via o mundo de maneira diferente? Percebia que poderia trabalhar, mas também cantar? O talento de uma pessoa pode ser o seu trabalho? As pessoas podem ter vários talentos, por exemplo: cantar, pintar, ser esportista? 


\title{
Menina bonita do laço de fita
}

\author{
Ana Maria Machado, ilustrações Claudius
}

Dado biográfico: nasceu no Rio de Janeiro, em 1942, Graduou-se em Letras e dedi-

cou-se, também, à pintura. Começou a escrever textos para crianças, em 1969, na

revista Recreio.

Na vida da escritora Ana Maria Machado, os números são sempre generosos. São 33 anos de carreira, mais de 100 livros publicados no Brasil e em mais de 17 países somando mais de dezoito milhões de exemplares vendidos. Os prêmios conquistados ao longo da carreira de escritora também são muitos, tantos que ela já perdeu a conta. ${ }^{105}$

Era uma vez uma menina linda, linda.

Os olhos dela pareciam duas azeitonas pretas, daquelas bem brilhantes.

Os cabelos eram enroladinhos e bem negros, feito fiapos da noite. A pele era escura e lustrosa, que nem o pêlo da pantera negra quando pula na chuva.

Ainda por cima, a mãe gostava de fazer trancinhas no cabelo dela e enfeitar com laço de fita colorida. Ela ficava parecendo uma princesa das Terras da África, ou uma fada do Reino do Luar.

Do lado da casa dela morava um coelho branco, de orelha cor-de-rosa, olhos vermelhos e focinho nervoso sempre tremelicando. O coelho achava a menina a pessoa mais linda que ele tinha visto em toda a vida. E pensava:

- Ah, quando eu casar quero ter uma filha pretinha e linda que nem ela...

Por isso, um dia ele foi até a casa da menina e perguntou:

- Menina bonita do laço de fita, qual é teu segredo pra ser tão pretinha?

A menina não sabia, mas inventou:

- Ah, deve ser porque eu caí na tinta preta quando era pequenina...

O coelho saiu dali, procurou uma lata de tinta preta e tomou banho nela.

Ficou bem negro, todo contente. Mas aí veio uma chuva e lavou todo aquele pretume, ele ficou branco outra vez.

Então ele voltou lá na casa da menina e perguntou outra vez:

- Menina bonita do laço de fita, qual é teu segredo pra ser tão pretinha?

A menina não sabia, mas inventou:

- Ah, deve ser porque eu tomei muito café quando era pequenina.

O coelho saiu dali e tomou tanto café que perdeu o sono e passou a noite toda fazendo xixi.

Mas não ficou nada preto.

Então ele voltou lá na casa da menina e perguntou outra vez:

- Menina bonita do laço de fita, qual é teu segredo pra ser tão pretinha?

A menina não sabia, mas inventou:

- Ah, deve ser porque eu comi muita jabuticaba quando era pequenina.

O coelho saiu dali e se empanturrou de jabuticaba até ficar pesadão, sem conseguir sair do lugar. O máximo que conseguiu foi fazer muito cocozinho preto e redondo feito jabuticaba.

Mas não ficou nada preto.

Por isso, daí a alguns dias ele voltou lá na casa da menina e perguntou outra vez:

- Menina bonita do laço de fita, qual é teu segredo pra ser tão pretinha?

A menina não sabia e já ia inventando outra coisa, uma história de feijoada, quando a mãe dela, que era uma mulata linda e risonha, resolveu se meter e disse:

- Artes de uma avó preta que ela tinha...

105 Disponível em: <http:/www.anamariamachado.com/biografia.html>. Acesso em 16/11/2006. 
Aí o coelho - que era bobinho, mas nem tanto - viu que a mãe da menina devia estar mesmo dizendo a verdade, porque a gente se parece é com os pais, os tios, os avós e até com os parentes tortos.

E se ele queria ter uma filha, pretinha e linda que nem a menina, tinha era que procurar uma coelha preta para casar.

Não precisou procurar muito.

Logo encontrou uma coelhinha escura como a noite, que achava aquele coelho branco uma graça.

Foram namorando, casando e tiveram uma ninhada de filhotes, que coelho quando desanda a ter filhote não pára mais.

Tinha coelho pra todo gosto: branco bem branco, branco meio cinza, branco malhado de preto, preto malhado de branco e até uma coelha bem pretinha. Já se sabe, afilhada da tal menina bonita que morava na casa ao lado. guntava:

E quando a coelhinha saía de laço colorido no pescoço, sempre encontrava alguém que per-

- Coelha bonita do laço de fita, qual é teu segredo pra ser tão pretinha?

E ela respondia:

- Conselhos da mãe da minha madrinha...

\section{Análise}

Pertencente à Literatura Contemporânea, esse conto busca valorizar as diferenças e resgatar a dignidade da etnia negra: "Ela ficava parecendo uma princesa das Terras da África ou uma fada do Reino do Luar".

Valoriza a imaginação e a criatividade da criança. Ao responder às perguntas do coelho que queria saber o segredo para ser pretinho a menina diz: "porque eu caí na tinta quando pequenina"; "porque eu tomei café quando era pequenina"; "porque eu comi muita jabuticaba quando era pequenina" e assim por diante fazendo uso de sua imaginação criativa..Apresenta uma relação familiar de respeito sem autoritarismo. "[...] quando a mãe dela que era uma mulata linda e risonha resolveu se meter e disse:- Artes de uma avó preta que ela tinha...", vindo em socorro da menina para resolver a questão apresentada pelo coelho. A negritude aqui é legitimada, a menina era feliz. Ao contrário de Ditinho, em Nhá Dita contou, que era triste e queria ser branco e de outro conto da Literatura Tradicional, O Negrinho, que embora o poema narrativo não expresse, claramente, o sentimento da personagem, mestre Tomás demonstra o seu infortúnio: "Que mal fez esse pretinho infeliz? Que é preto porque Deus quis?" 


\section{Proposta Pedagógica}

Ler a história uma ou mais vezes com e para os alunos. Perguntar se gostaram da história e se já a conheciam. Que nome vocês dariam à menina bonita? Se você fosse o coelho o que mais gostaria de saber? Quem sabe como é uma princesa das terras da África?

Dialogar com os alunos sobre as etnias: indígena, branca e negra na formação do povo brasileiro. Se for alunos de séries mais avançadas o professor poderá fazer um levantamento de questões sobre a negritude e anotá-las no quadro de giz ou branco. Dispor as questões por tema e discuti-las em pequenos grupos. Abrir uma plenária e anotar as conclusões em folhas de papel pardo e afixar em um mural na sala de aula.

Caso não tenha emergido a questão racial, o professor poderá provocar a classe para essa questão e sugerir pesquisa sobre projetos já existentes e em andamento. Fazer um levantamento sobre publicações na área de Literatura Infantojuvenil que abordam a questão da cultura afro-descendente. 


\title{
VII - CONCLUSÃO
}

\begin{abstract}
'Se há uma 'utilidade' da literatura na escola, muito mais que ensinar gramática e coisas assim, é a de possibilitar, no plano da expressão, o contato do leitor com uma linguagem expressiva, renovadora e poética, e, no plano do conteúdo, a discussão de temas que, no fundo, acabam sempre especulando sobre a construção do significado da existência."
\end{abstract}

Ricardo Azevedo

A Literatura Infantil como qualquer outra forma de expressão artística se relaciona com o contexto social, em seu sentido mais abrangente. Relação que pode se estabelecer no confronto ou na consonância, mas que sempre existirá, mesmo quando o escritor inventa um texto introspectivo, de caráter subjetivo. A relação autor-texto-mundo será sempre da perspectiva de alguém (o autor) pousando seu olhar sobre o mundo, relação que gera uma outra: leitor-texto-mundo. Mas que leitor, que texto, que autor e que mundo?

Quando o adulto quer entrar no universo literário da criança e do jovem, não é suficiente buscar motivos e justificativas para entender a relação dialética autorleitor, mediada pelo texto. É necessário que o adulto-escritor possa entender quem é o sujeito-leitor para que a Literatura Infantil, assim como as outras Literaturas, se explicite para que seu significado seja alcançado.

Foi nessa direção que delineamos nossa pesquisa sobre o papel do professor no e para o ensino da Literatura Infantil, pois, ele será o mediador da criança com o texto, que é o mediador da relação escritor-leitor. Dentro do espaço escolar, não paira dúvida sobre a importância da L.I. na formação das crianças e jovens. Por que então prevalece, ainda, uma relação hermética e sufocante entre texto literário e criança-leitora?

Para encontrar respostas e apresentar propostas efetivas, recorremos à história da L.I. no Brasil e sobre a formação do professor. Levantamos títulos dirigidos às 
crianças do início do século XX ao início do século XXI. Confrontamos contextos históricos e esboçamos características das sociedades da época para entender os parâmetros vigentes na produção do texto, seus propósitos, e a atuação do professor na escolha no desdobramento da obra, em sala de aula. Concomitante à pesquisa desses dados, buscamos ainda conceitos que a Pedagogia teceu, nesse período delimitado, sobre o ser-criança.

Tínhamos, também, que definir um paradigma no ensino da L.I. que fundamentasse nossa proposta, ou seja, um método de ensino que privilegiasse o exercício da criatividade, a construção de um senso crítico e um aperfeiçoamento do sentir. Um método que respeitasse a criança como o ser que ela é, no qual vai se transformando ruma à idade adulta envolvida em um mundo em transformação, e comprometida com a evolução desse mesmo mundo.

Nesse sentido, é fundamental que o professor esteja capacitado para aplicar dinâmicas de leitura ${ }^{106}$ de modo que o aluno possa transcender a compreensão linear dos textos, levando-o a decodificar o não-escrito que se oculta nas entrelinhas e, em uma prática contínua, mantenha aceso o espírito investigativo, o espírito da descoberta.

Para que o professor possa exercer seu papel no ensino da L.I. é preciso que ele identifique em uma obra literária infantil características que a tornem 'um convite' a descobrir o gosto pela leitura, que possa contribuir para o desenvolvimento pessoal e social da criança. Isto implica em ter uma linguagem adequada, um discurso interativo, ilustrações atraentes, presença de valores humanos e éticos compondo assim o legado cultural, somando-se àquilo que a humanidade já conquistou.

${ }^{106}$ OLIVEIRA,op.cit.,12 ed. São Paulo, 2006. 
Para entendermos o presente e construirmos o futuro, é necessário conhecer o passado. Temos que nos valer desse princípio para desconstruir os antigos métodos no ensino com a L.I. e trazer à tona propostas revigorantes para o enriquecimento na relação dos sujeitos envolvidos no ato da leitura.

A L.I. no contexto tradicional se prestava ao objetivo de uma sociedade cuja concepção da criança era de um adulto em miniatura, em estado inferior e sem direito à voz. Era uma sociedade que se preocupava com a (boa) aparência, ainda que fosse preciso fingir para sustentar uma pseudo condição sócio-econômico-cultural. Nesse sentido, exaltava valores sociais, religiosos e familiares que garantissem um padrão de comportamento que não contrariasse os interesses do poder dominante em detrimento aos valores éticos, justos e humanos, sobretudo verdadeiros. Sendo assim, à criança eram impostas a obediência e submissão, sem direito de questionar e criticar o status quo, sem espaços para questionamentos e para o exercício do imaginário. A criança deveria ser educada para dar continuidade às crenças e valores construídos pela sociedade daquela época. Dessa maneira, obviamente, ficava garantido o poder aos já poderosos e o conformismo aos desfavorecidos.

Essa função de promover a propaganda de uma sociedade cheia de ranços marcou a L.I., no Brasil, até o início dos anos 70. Por vários motivos, até porque as revoluções no campo das idéias são inevitáveis, respiravam-se novos ares, emancipadores do peso tradicional e emergiu, sorrateiramente, uma L.I. em que o eixo central era despertar o imaginário da criança, de modo a propiciar condições para o desenvolvimento do senso crítico e da criatividade, do comprometimento com um mundo em transformação e de promover o desenvolvimento de sua capacidade crítica/criativa. A concepção de criança, nesse contexto, é a de um ser em desenvolvimento, com direito à educação e recursos para a sua formação. Dentro dessa nova 
visão, os contos clássicos e a literatura de heróis e mitos são redescobertos pelas suas funções - importantes - no desenvolvimento do imaginário que se prolonga no desenvolvimento do ser humano.

A contribuição do nosso trabalho ao ensino da L.I. é apresentar critérios de escolha de obras adequadas aos trabalhos docentes e estimular o professor para a elaboração de propostas pedagógicas que resultam em gosto pela leitura e exploração da realidade de vida do leitor. Para isso, selecionamos 9 histórias dos diferentes períodos em que foram feitas análise e sugestões de atividades a partir de um roteiro, que pode servir de base na elaboração de outros roteiros para outras histórias. Nosso objetivo foi oferecer subsídios ao trabalho do professor no ensino da L.I., enfatizando sempre seu papel mediador entre o livro e crianças-leitoras.

Acreditamos ter contribuído com a formação de professores para o ensino da L.I. nas séries iniciais do Ensino Fundamental I, diante do precário e/ou escasso preparo por eles recebido em sua escolaridade.

Ao situarmos, ainda que minimamente as obras focalizadas e seus autores em seus tempos e contextos, entendemos estar criando para o professor uma oportunidade de aprendizagem que ultrapassa as informações contextualizantes da obra. Esperamos que o professor possa perceber a relação entre L.I. e a vida, captar desse modo a propriedade formativa da Literatura, sentir a necessidade e importância de estabelecer essa relação na escolha de livros para o trabalho docente que pretenda realizar com eles.

Ao criarmos as 5 categorias de análise - tema, mensagem, tipo de discurso, tipo de linguagem, concepção de criança - acreditamos estar oferecendo 5 instrumentos de análise das obras a serem escolhidas por ele para o trabalho docente. 
E com esses procedimentos esperamos evidenciar a importância da leitura do texto pelo docente anteriormente ao trabalho a ser realizado junto às crianças. Assim como não nos esquecemos, ao longo desse trabalho, da polissemia do texto (posto que as significações são um trabalho de construção que se dá nas relações que o leitor estabelece com o texto, a partir de suas experiências de vida e de seus saberes), ressaltamos aqui novamente que as categorias criadas não são exaustivas, podendo mesmo o professor re-elaborá-las; que em função dessa mesma polissemia esteja atento e aberto para as leituras realizadas pelas crianças. A leitura do docente serve para capacitá-lo a uma conduta didática adequada à exploração do "potencial formativo" da L.I e em nenhum momento deverá ser imposta aos alunos, mas necessariamente deverá constar dentre as leituras efetuadas por eles, como uma das leituras possíveis; ou seja, a leitura do adulto, que é o professor, não deve ser subtraída e nem tão pouco imposta aos discentes. Deve, sim, existir. É importante que os alunos se defrontem com as diferentes leituras realizadas em sala de aula pelos colegas e pelo professor. Será em meio a eles que irão rever a sua leitura inicial, ponderando as demais de que vai tomando conhecimento e construindo, reconstruindo processualmente a sua compreensão pessoal da obra e da vida. Ao disponibilizarmos, no anexo, o texto de todas as obras analisadas nesta pesquisa, estamos oferecendo um material de estudo e pesquisa de obras de L.I. adequado a cursos de formação inicial de professores e de programas de formação continuada dos docentes. Bem como alimentamos a pretensão/esperança de que o próprio trabalho de pesquisa aqui realizado sirva a esse mesmo fim. Acrescentando, ainda, nossa preocupação em tornar mais acessível ao professor em exercício de magistério, uma variedade de obras de Literatura para crianças dos diferentes períodos aqui considerados, tendo em vista as dificuldades de acesso aos materiais de ensino, 
especialmente de L.I., decorrente seja das precárias condições de exercício do trabalho do docente, seja pela precariedade de formação, neste campo de conhecimento.

Não poderíamos finalizar este trabalho sem duas importantes constatações:

- a ausência da expressão L.I., denominadora deste campo de conhecimento, nos documentos oficiais que orientam no momento presente a Educação Brasileira no que se refere às séries iniciais do Ensino Fundamental;

- a ausência da concepção de que Literatura Infantil é "arte de compor ou escrever trabalhos artísticos em prosa ou em verso".

Posto que já na LDB 9394/96 as considerações do Ensino das Artes destacam que: " $§ 2^{\circ} \mathrm{O}$ ensino da arte constituirá componente curricular obrigatório, nos diversos níveis da educação básica, ajustando-se às faixas etárias e às condições da população escolar, sendo facultativa nos cursos noturnos." ${ }^{107}$

Colocando lado a lado estas considerações e a ênfase atribuída ao exercício da leitura no "desenvolvimento da capacidade de aprender, tendo como meios básicos o pleno domínio da leitura, da escrita e do cálculo; [...]"108, fica inconcebível a ausência da L.I. como campo de conhecimento reconhecido seja nos PCN's, nas orientações sobre o ensino de Língua Portuguesa, ou nas orientações sobre o Ensino das Artes, seja na formação de professores para séries iniciais do Ensino Fundamental.

Considerações estas que são aquelas tecidas tanto pelas teóricas da L.I. e de seu ensino quanto ao longo deste trabalho de pesquisa, um dos importantes passos desse meu já longo caminho de formadora de professores sobre o ensino da L.I., que me fazem compreender esse percurso como um caminho sem fim, eternamente em construção. Construção coletiva e solidária com aqueles professores de L.I., de

\footnotetext{
${ }^{107}$ BRZEZINSKI, Iria (org.). LDB interpretada: diversos olhares se entrecruzam. 2.ed., São Paulo, Cortez, 1998, p.224.

108 Ibid., p. 225.
} 
estudiosos e de pesquisadores que transitam pelas múltiplas veredas dessa rede de conhecimentos.

Caminho que, à despeito do não reconhecimento oficial nos documentos orientadores da educação de nossas crianças e jovens, se constrói continuamente em os modestos passos daqueles que por ele caminham. 


\section{BIBLIOGRAFIA}

ALENCAR, Francisco et al. História da sociedade brasileira. Rio de Janeiro: Ao livro técnico, 1979.

ALMEIDA, Fernanda Lopes de. il. Fernando de Castro Lopes. O Equilibrista. 5.ed. São Paulo: Ática, 1987.

ANDERSEN, Hans C. il.Franta Richter. O Patinho Feio. Org. Arnaldo de Oliveira Barreto. São Paulo/Rio de Janeiro: Weiszflog Irmãos/Melhoramentos, 1915/2003.

. il. originais de Vilh. Pedersen e Lorenz Frolich. O guardador de porcos. In:__ Contos de Andersen. 7.ed., Trad. Guttorm Hanssen, Rio de Janeiro: Paz e Terra, 1978.

ARAGÃO,José Carlos. O Menino que engoliu o quatro. São Paulo: Paulinas, 2002.

ARIÈS, Philippe. História social da criança e da família. 2.ed. Trad. Dora Flaskman, Rio de Janeiro: Guanabara, 1981.

ARROYO, Leonardo. Literatura Infantil Brasileira. São Paulo: Melhoramentos, 1988.

AZEVEDO, Paulo César (coord.). Monteiro Lobato, vida, realidade e sonho. São Paulo: Emporium brasilis memória e produção cultural, 1998.

BETTELHEIM, Bruno. A psicanálise dos contos de fadas. 6.ed. Trad. Arlene Caetano, Rio de Janeiro: Paz e Terra, 1980.

BILDER, Paul. il. Eliana B. Brandão. A galinha ruiva: recolha do folclore inglês. São Paulo: Melhoramentos, [19--], série Ver e Ouvir.

BOSI, Ecléa. Memória e Sociedade: lembranças de velhos. 2.ed. São Paulo: EDUSP,1987.

BRZEZINSKI, Iria (org.). LDB interpretada: diversos olhares se entrecruzam. 2.ed. São Paulo, Cortez, 1998.

CALDEIRA, Jorge et al. Viagem pela História do Brasil. São Paulo: Companhia das Letras, 1997.

CAMARGO, Luís. Ilustração do livro infantil. Belo Horizonte: Lê, 1995.

CAMBI, Franco. História da Pedagogia. Trad. Álvaro Lorencini. São Paulo: UNESP, 1999.

CÂNDIDO, Amélia Fernandes. Literatura Infantil... mais além: a especificidade da literatura infantil como instrumento de estímulo ao desenvolvimento da linguagem. 2001.179 f. Dissertação (Mestrado em Estudos Comparados de Literaturas de Língua Portuguesa) - Faculdade de Filosofia Letras e Ciências Humanas, Universidade de São Paulo, 2001. 
COELHO, Nelly Novaes. O ensino de Literatura. São Paulo: FTD, 1966.

. Dicionário Crítico da literatura infantil e juvenil brasileira: séculos $X I X e$ XX. 4.ed. São Paulo: EDUSP, 1995.

. O conto de fadas: símbolos, mitos, arquétipos. São Paulo: DCL, 2003.

. Literatura infantil: teoria, análise, didática. São Paulo: Moderna, 2000. ca, 1991.

Panorama histórico da literatura Infantil e Juvenil. 4.ed. São Paulo: Áti-

. Literatura: arte, conhecimento e vida. São Paulo: Peirópolis, 2000.

COLASANTI, Marina. il. da autora. O lobo e o carneiro no sonho da menina. Rio de Janeiro: Ediouro, 1994.

COMÊNIO, João Amos. Didática Magna. Trad. Nair Fortes Abu-Merhy. Rio de Janeiro: Organização Simões, 1954.

CORRAL, Luis Sánches. Literatura Infantil y lenguaje literario. Buenos Aires: Ediciones Piados Ibérica, 1995.

COTOWESKI, Angelino. il. Joselito. Chiquinho o mexe-mexe. In: Segundo livro de leitura. 2.ed. Petrópolis -RJ: Vozes, 1963.

. il. Joselito. Lição merecida. In: Segundo livro de leitura. 2.ed. Petrópolis-RJ: Vozes, 1963.

DEIHL, Edna Groff. il. A. E, Kennedy e Roberta Paflin. O porquinho dorminhoco. 2.ed. Trad. Mário Donato e Marcos Rei, São Paulo: Melhoramentos, [s.d.].

DI GIOVANNI, Maria Lucia Ruiz. História: coleção magistério $2^{\circ}$ grau. São Paulo: Cortez, 1992.

ESTÉS, Clarissa Pinkola. Mulheres que correm com os lobos: mitos e histórias do arquétipo da mulher selvagem. 11.ed. Trad. Waldéa Barcellos, Rio de Janeiro: Rocco, 1997.

FAZENDA, Ivani (org.). Metodologia da pesquisa educacional. São Paulo: Cortez, 1989.

FRANCO, Maria Laura Puglisi Barbosa. Análise do conteúdo. 2.ed. Brasília: Líber Livro Editora, 2005.

FREIRE, Paulo. Pedagogia do oprimido. 22.ed. Rio de Janeiro: Paz e Terra, 1993.

FURNARI, Eva. Amendoim. São Paulo: Paulinas, 2000.

. Zuza e Arquimedes. São Paulo: Paulinas, 2000.

GARCIA, Edson Gabriel. A história da bolinha curiosa. São Paulo: Loyola, 1983. 
GIÁCOMO, Maria Thereza Cunha e. il. Darcy Penteado. Bitu, o carneirinho sujo. 2.ed. São Paulo: Melhoramentos, [s.d].

. il. Hilda Bennett. O burrinho verde. 8.ed. São Paulo: Melhoramentos, [s.d].

GÓES, Lúcia Pimentel. A aventura da literatura para crianças: formas de avaliação da literatura infantil e juvenil através da obra de Francisco Marins. São Paulo: Melhoramentos, 1991.

1991.

Introdução à Literatura infantil e Juvenil. 2.ed. São Paulo: Pioneira,

Olhar de descoberta: proposta analítica de livros que concentram várias linguagens. São Paulo: Paulinas, 2003.

Assim caminhou a humanidade, sem pressa. In:

Retrospectiva

sobre a importância da imagem na história da Humanidade. Disponível em: www.tve.brasil.com.br/SALTO/boletins2002/lii/liitxt1.htm, Acesso em: 15/09/2006.

GRIMM, Jacob e Wilhelm. il. Janusz Grabianski. A gata borralheira. In: .Os contos de Grimm. Trad. Tatiana Belinky. São Paulo: Paulinas, 1989.

.il. Janusz Grabianski. Chapeuzinho Vermelho. In:

Os contos de Grimm. Trad. Tatiana Belinky. São Paulo: Paulinas, 1989.

HOFFMANN, Heinrich. Paulina pega-fogo. In: João Felpudo. 5.ed. versão Guilherme de Almeida, São Paulo: Melhoramentos, [1921].

Tonico balança e cai. In: João Felpudo. 5.ed. versão Guilherme de Almeida, São Paulo: Melhoramentos, [1921].

. O negrinho. In: João Felpudo. 5.ed. versão Guilherme de Almeida, São Paulo: Melhoramentos, [1921].

IACOCCA, Liliana \& Michele. Farra no formigueiro. 3.ed. São Paulo: Ática, 1991.

IDELFONSO, Frei. A carteira perdida. In: O que eu li e ouvi. São Paulo: Paulinas, 1943.

ISER, Wolfgang. $\mathbf{O}$ ato da leitura: uma teoria do efeito estético. Trad. Johannes Kretschmer. São Paulo: Editora 34, 1999.

JESUALDO. A Literatura Infantil. Trad. James Amado. São Paulo: Cultrix, 1993.

KRAMER, Sonia. Por entre as pedras: arma e sonho na escola. 3.ed. São Paulo: Ática, 1998.

LDB - Lei de diretrizes e Bases da Educação Nacional: texto aprovado na Comissão de Educação, Cultura e Desporto na CD, com comentários de Demerval Saviani et al. São Paulo: Cortez, 1990.

LIBÂNEO, José Carlos. Didática. 23.ed. São Paulo: Cortez, 2004. 
LOBATO, Monteiro. A Barca de Gleyre. Quarenta anos de correspondência entre Monteiro Lobato e Godofredo Rangel. São Paulo: Companhia Editora Nacional, 1944 , volume I. $\overline{\text { ense, } 1994 .}$

il. Manoel Victor Filho. Reinações de Narizinho. 50.ed. São Paulo: Brasili. il. Manoel Victor Filho. Fábulas. 48.ed. São Paulo: Brasiliense, 1994. 1994. . il. Manoel Victor Filho. Memórias da Emília. 42.ed. São Paulo: Brasiliense,

LOPES, Eliane Maria Teixeira et al. 500 Anos de Educação no Brasil. Belo Horizonte: Autêntica, 2003.

LÜDKE, Menga e ANDRÉ, Marli E.D.A. Pesquisa em educação: abordagens qualitativas. São Paulo: EPU, 1986.

MACHADO, Ana Maria. il. Claudius. Menina bonita do laço de fita. 7.ed. São Paulo: Ática, 2004. 1998.

il. Helena Alexandrino. Avental que o vento leva. 5.ed. São Paulo: Ática,

MANTOVANI, Fryda S. Sobre las hadas. Buenos Aires: Editorial Nova, 1959.

MERZ, Hilda J. Villela et al. Histórias e resenhas da obra infantil de Monteiro Lobato. São Paulo: Melhoramentos, 1996.

Ministério da Educação e do Desporto. Secretaria de Educação Fundamental. Parâmetros Curriculares Nacionais - Língua Portuguesa, Brasília, 1997.

MOTT, Odete de Barros. Nhá Dita contou. São Paulo: Paulinas, 1962.

O GALO da casa. As mais belas histórias. São Paulo: Paulinas, 1957.

O MENINO mal criado. Histórias de crianças e animais. São Paulo:

Francisco Alves, 1932, coleção João Köpke.

OLIVEIRA, Maria Alexandre. Leitura Prazer: interação participativa da criança com a Literatura Infantil na escola. 3.ed. São Paulo: Paulinas, 2004.

. Dinâmicas em Literatura Infantil. 12 ed. São Paulo: Paulinas, 2006.

ORTOF, Sylvia. il. Ana Raquel. Se as coisas fossem mães. Rio de Janeiro: Nova Fronteira, 1984.

PENTEADO, Heloísa Dupas. Comunicação Escolar - uma metodologia de ensino. São Paulo: Editora Salesiana, 2002.

Cortez, 1998.

(org. e aut.). Pedagogia da Comunicação: teorias e práticas. São Paulo:

. Televisão e Escola: conflito ou cooperação. São Paulo: Cortez, 1991. 
PEREIRA, Marli Assunção Gomes. il. Teruyo Kajiki de Souza. O reino das borboletas brancas. 7.ed. São Paulo: Paulinas, 2002.

PERRAULT, Charles. O pequeno polegar. In: Maria Stela Gonçalves. São Paulo: Paulus, 2005. . Contos de Perrault. Trad. O mestre gato ou Gato de Botas. In: Maria Stela Gonçalves. São Paulo: Paulus, 2005. Contos de Perrault. Trad.

PERROTTI, Edmir. O texto sedutor na literatura infantil. São Paulo: Ícone, 1986.

38. Confinamento cultural, infância e leitura. São Paulo: Summus, 1990. v.

PIMENTA, Selma Garrido e GHEDIN, Evandro (orgs.). Professor reflexivo: gênese e crítica de um conceito. São Paulo: Cortez, 2002.

PIMENTEL, Figueiredo. il. Julião Machado. Histórias da avozinha: livro para crianças. São Paulo: Livraria Quaresma, 1959.

RIOS, Rosana. il. Semíramis Nery Paterno. Timóteo, o tatu poeta. São Paulo: Scipione, 1992.

RIBEIRO, Maria Luisa Santos. História da educação brasileira: a organização escolar. 11 ed. São Paulo: Cortez/Autores Associados, 1991.

RIZZINI, Jorge. il. Messias. Vida de Monteiro Lobato (Para a Infância e Juventude). 2.ed. São Paulo: Difusora Cultural, 1966.

ROCCO, Maria Thereza Fraga. Literatura/Ensino: uma problemática. São Paulo: Ática, 1981.

ROCHA, Ruth. il. Walter Ono. O reizinho mandão. São Paulo: Quinteto Editorial, 1997.

SANDRONI, Laura. De Lobato a Bojunga - as reinações renovadas. Rio de Janeiro: Agir, 1987.

SANTOS, Joel Rufino dos. il. Lúcia Lacourt. O curumim que virou gigante. 6.ed. São Paulo: Ática, 1989.

SAVIANI, Dermeval. Escola e Democracia. São Paulo: Cortez, 1983.

SCHON, Donald A. Formar professores como profissionais reflexivos. In:

Os Professores e a sua Formação. Lisboa, Publicação Dom Quixote, 1992.

SECRETARIA DE ESTADO DA EDUCAÇÃO DE SÃO PAULO - Coordenadoria de estudos e normas pedagógicas. Proposta Curricular para o ensino de Língua Portuguesa $-1^{\circ}$ grau. 4.ed. São Paulo: SE/CENP, 1991.

SILVA, Ezequiel Theodoro. De olhos abertos. São Paulo: Ática, 1991.

SORIANO, Marc. Guide de Littérature pour la jeunesse. Paris: Delagrave, 2002. 
VENEZA, Maurício. il. do autor. Que lugar é este? São Paulo: Paulinas, 2003.

VYGOTSKI, L. S. A Formação Social da Mente: o desenvolvimento dos processos psicológicos superiores. São Paulo: Martins Fontes, 1991.

WERNEK, Regina Yolanda. A importância da imagem nos livros de literatura infantil e juvenil. In: Revista Tempo brasileiro, n 63, Rio de Janeiro, 1980.

WITTROCK, Merlin C. La investigación de la enseñanza, II - Métodos cualitativos y de observación. Trad.Glória Vitale. Barcelona: Ediciones Paidós Ibérica, 1989.

YUNES, Eliana. Presença de Monteiro Lobato. Rio de Janeiro: Divulgação e Pesquisa, 1982.

ZILBERMAN, Regina \& MAGALHÃES, Ligia Cademartori. Literatura infantil: autoritarismo e emancipação. In: Ensaios 82. São Paulo: Ática, 1987.

ZILBERMAN, Regina \& LAJOLO, Marisa. Um Brasil para crianças: para conhecer a literatura infantil brasileira: histórias, autores e textos. São Paulo: Global Editora, 1988.

ZILBERMAN, Regina. Estética da Recepção e História da Literatura. São Paulo: Ática, 1989.

ZIRALDO. il. do autor. Os dez amigos. 22.ed. São Paulo: Melhoramentos, 1998. 1994. . il. do autor. O menino maluquinho. 48.ed. São Paulo: Melhoramentos,

ZUMTHOR, Paul. A letra e a voz: a literatura medieval. Trad. Amálio Pinheiro e Jerusa P. Ferreira. São Paulo: Companhia das Letras, 2001. 


\section{ANEXO}

TEXTOS ORIGINAIS DAS OBRAS SELECIONADAS 


\title{
A - LITERATURA CLÁSSICA INFANTIL
}

\section{O MESTRE GATO OU O GATO DE BOTAS}

\author{
Charles Perrault
}

Um moleiro deixou todos os seus bens aos três filhos que tinha, seu moinho, seu asno e seu gato. Como a partilha não tardou a ser feita, nem o notário nem o procurador foram chamados. Eles logo gastariam todo o pobre patrimônio. O primogênito ficou com o moinho, o segundo com o asno e o caçula não recebeu senão o gato. Este último não podia se consolar com tão pobre quinhão. Meus irmãos - dizia ele - poderão ganhar a vida honradamente se associarem; quanto a mim, quando tiver comido meu gato e tiver feito um agasalho com sua pele, morrerei de fome. O gato que entendia o que era dito, mas que não dava mostras de fazê-lo, lhe diz com ar grave e sério: Não vos aflijais, meu amo, tendes apenas de me dar um saco e mandar fazer para mim um par de botas para andar nos abrolhos; vereis então que não foste tão mal aquinhoado quanto credes. Embora não lhe tenha dado muito crédito, o dono do gato tinha visto este último fazer tais acrobacias para pegar ratos e camundongos, como quando se pendurava pelos pés, ou se escondia na farinha para se fazer de morto, que não desesperou de ser socorrido pelo animal em sua miséria. Quando teve aquilo que pedira, o gato pôs as botas corajosamente e, colocando o saco no pescoço, pegou seus cordões com as patas da frente e se dirigiu a uma coelheira em que era grande o número de coelhos. $\mathrm{O}$ gato pôs farelo e brotos no saco e, estendendo-se como se estivesse morto, esperou que algum coelhinho pouco experiente ainda das astúcias deste mundo viesse meter-se no saco para comer o que nele havia posto. Mal se estendeu no chão, teve seu desejo satisfeito: um estouvado coelhinho entrou nele, e o mestre gato, puxando imediatamente os cordões, o prendeu e o matou sem misericórdia. Cheio de júbilo por sua proeza, ele se dirigiu ao palácio do rei e pediu para falar a este. Fizeram-no subir aos aposentos de sua majestade onde, tendo entrado, fez grande reverência ao rei e lhe disse: Eis, senhor, um coelho de coelheira que o senhor marquês de Carabas (era o nome que escolheu para dar a seu dono) me encarregou de vos apresentar de sua parte. Dize a teu senhor - responde o rei - que eu lhe agradeço e que seu presente me agradou. De outra vez, o gato foi se esconder num trigal, mantendo sempre aberto o saco; e quando duas perdizes nele entraram, puxou os cordões e as aprisionou a ambas. Foi em seguida apresentá-las ao rei, tal como fizera com o coelho. O rei recebeu novamente com prazer as duas perdizes e mandou dar-lhe de beber. O gato continuou assim, durante dois ou três meses, a levar ao rei, de tempo em tempo, presas de caça de seu amo. Certo dia em que soube que o rei devia sair a passeio pelas margens do rio com sua filha, a mais bela princesa do mundo, o gato disse a seu dono: Se quiserdes seguir meu conselho, vossa fortuna estará feita; tendes apenas que vos banhar no rio no lugar que vos indicarei, e em seguida me deixar agir. O marquês de Carabas fez o que seu gato lhe aconselhava, sem saber para que serviria. Enquanto se banhava, o rei passou e o gato começou a gritar com todas as forças: Socorro, socorro, o senhor marquês de Carabas está se afogando! Diante desse grito, o rei olhou pela portinhola e conhecendo o gato que o presenteara com presas de caças, ordenou a seus guardas que corressem em auxílio do senhor marquês de Carabas. Enquanto era retirado o pobre marquês do rio, o gato se aproximou de carruagem e disse ao rei que, no momento em que seu amo se banhava, tinham vindo ladrões que roubaram suas vestes, embora ele tivesse gritado ao ladrão com todas as forças; o velhaco as escondera sob uma grande pedra. O rei ordenou imediatamente aos oficiais de seu guarda-roupa que fossem buscar uma de suas mais lindas roupas para o senhor marquês de Carabas. O rei lhe dedicou mil delicadezas e, como as belas vestes que acabavam de lhe ser dadas ressaltavam sua boa figura (pois ele era bonito, e bem feito de corpo), a filha do rei o considerou ao seu gosto, e ainda o Marquês de Carabas não lhe lançara dois ou três olhares muito respeitosos, e um pouco ternos, e já estava ela loucamente enamorada. $\mathrm{O}$ rei quis que ele subisse em sua carruagem e saísse a passeio com eles. $\mathrm{O}$ gato, encantado por ver que seu plano começava a ter êxito, tomou a frente e, tendo encontrado camponeses que ceifavam um prado, disse-lhes: Bons homens que ceifais, se não disserdes ao rei que o prado que estais ceifando pertence ao senhor marquês de Carabas, sereis todos picados em pedaços como carne para pastel. O rei não deixou de perguntar aos camponeses de quem era o prado que ceifavam. Do senhor marquês de Carabas, disseram eles todos juntos, pois a ameaça do gato os atemorizara. Tendes aí uma bela herança, diz o rei ao marquês de Carabas. Vede, senhor - respondeu o marquês -, trata-se de um prado que nunca deixa de produzir abundantemente todos os anos. O mestre gato, que continuava a avançar na frente, encontrou segadores e lhes disse: Bons homens que segais, se não disserdes que todos estes trigais pertencem ao senhor marquês de Carabas, sereis todos picados em pedaços como, carne para pastel. O rei, que passou um momento depois, quis saber a quem pertenciam todos os trigais que via. Ao senhor marquês de Carabas, responderam os segadores, e o rei voltou a rejubilar-se com o marquês. $\mathrm{O}$ gato, que ia à frente da carruagem, dizia sempre a mesma coisa a todos os que encontrava; e o rei se surpreendia com os grandes bens do senhor marquês de Carabas. O mestre gato chegou enfim a um belo castelo cujo dono era um ogro, o mais rico já visto, pois todas as terras pelas quais o rei passara pertenciam a esse castelo. O gato, que tivera o cuidado de informar-se quem era esse ogro, e o que sabia fazer, pediu para falar-lhe, dizendo que não desejava passar tão perto de seu castelo sem ter a honra de reverenciá-lo. $\mathrm{O}$ ogro recebeu-o tão civilizadamente quanto o pode fazer um ogro, e o fez repousar. Asseguraram-me - disse o 
gato - que tendes o dom de vos transformar em qualquer espécie de animal, que podeis, por exemplo, vos transformar num leão, num elefante. É verdade - respondeu o ogro bruscamente -; e, para vos mostrar, vou transformar-me num leão. O gato ficou tão assustado de ver um leão diante de si que não tardou a subir no beiral, não sem dificuldade e perigo, visto que suas botas não serviam para andar sobre o telhado. Algum tempo depois, o gato, tendo visto que o ogro retomara sua forma primitiva, desceu e confessou ter sentido muito medo. Asseguraram-me ainda - disse o gato - , mas não pude acreditar, que tendes também o poder de tomar a formar dos menores animais, por exemplo, de vos transmutar num rato, num camundongo; confesso-vos que considero esse feito inteiramente impossível. Impossível - replica o ogro - vós vereis. E, ao mesmo tempo, transformou-se num camundongo, que começou a correr pelo assoalho. Mal percebeu a transformação, o gato lançou-se em cima dele e o comeu. No entanto, o rei, que viu ao passar o belo castelo do ogro, quis entrar nele. O gato, que ouviu o ruído da carruagem que passava sobre a ponte levadiça, correu em seu encalço, e disse ao rei: Bem-vindo, majestade, ao castelo do senhor marquês de Carabas! Como, senhor marquês? - exclamou o rei - Também este castelo é vosso? Nada há de mais belo do que esta corte e que todas estas edificações que a cercam; vejamos o interior, por favor. O marquês deu a mão à jovem princesa e, seguindo o rei, que subiu primeiro, entraram todos numa grande sala na qual encontraram uma magnífica refeição que o ogro preparara para seus amigos que deviam chegar nesse mesmo dia, mas que não tinha ousado entrar ao saber que o rei lá estava. $\mathrm{O}$ rei, encantado com as qualidades do senhor marquês de Carabas, assim como estava sua filha, louca por ele, e vendo os grandes bens que possuía, disse-lhe, depois de ter bebido cinco ou seis copos: Só cabe a vós, senhor marquês, desejar ser meu genro. O marquês, fazendo grandes referências, aceitou a honra que lhe era oferecida pelo rei; e desposou a princesa nesse mesmo dia. $\mathrm{O}$ gato se tornou grande senhor e não correu mais atrás de camundongos senão para se divertir.

\section{Moral}

Por maior que seja a vantagem

De gozar de uma rica herança

A nós advinda de pai a filho,

Aos jovens de modo geral,

A habilidade e o empenho

Valem mais do que os bens adquiridos.

\section{Outra Moral}

Se o filho de um moleiro, com tanta rapidez,

Ganha o coração de uma princesa,

E se faz admirar com olhos dolentes,

É que a roupa, a figura e a juventude,

Para inspirar ternura,

Nem sempre são meios indiferentes.

\section{CHAPEUZINHO VERMELHO}

\section{Irmãos Grimm}

Era uma vez uma meninazinha mimosa, que todo mundo amava assim que a via, mas mais que todos a amava a sua avó. Ela não sabia mais o que dar a essa criança. Certa vez, ela deu de presente um capuzinho de veludo vermelho, e porque este lhe ficava tão bem, e a menina não queria mais usar outra coisa, ficou se chamando Chapeuzinho Vermelho.

Certo dia, sua mãe lhe disse:

- Venha cá, Chapeuzinho Vermelho; aqui tens um pedaço de bolo e uma garrafa de vinho, leva isto para a vovó, ela esta doente e fraca e se fortificará com isto. Sai, antes que comece a esquentar, e quando saíres, anda direitinha e comportada e não saias do caminho, senão podes cair e quebrar o vidro e a vovó ficará sem nada. $\mathrm{E}$ quando chegares lá, não esqueças de dizer bom-dia, e não fiques espiando por todos os cantos.

- Vou fazer tudo como se deve, - disse Chapeuzinho Vermelho à mãe, dando-lhe a mão como promessa.

A avó, porem, morava lá fora na floresta, a meia hora da aldeia. E quando Chapeuzinho Vermelho entrou na floresta, encontrou-se com o lobo. Mas Chapeuzinho Vermelho não sabia que fera malvada era aquela, e não teve medo dele.

- Bom-dia, Chapeuzinho Vermelho, - disse ele.

- Muito obrigada, lobo.

- Para onde vai tão cedo, Chapeuzinho Vermelho?

- Para a casa da vovó.

- E o que trazes aí debaixo do avental?

- Bolo e vinho. Foi assado ontem, e a vovó fraca e doente vai saboreá-lo e se fortificar com o vinho. 
- Chapeuzinho Vermelho, onde mora a tua avó?

- Mais um bom quarto de hora adiante no mato, debaixo dos três grandes carvalhos, lá fica a sua casa; embaixo ficam as moitas de avelã, decerto já sabes isso, - disse Chapeuzinho Vermelho.

O lobo pensou consigo mesmo: "Esta coisinha nova e tenra, ela é um bom bocado que será ainda mais saboroso do que a velha. Tenho de ser muito esperto para apanhar as duas".

Então ele ficou andando ao lado de Chapeuzinho Vermelho e logo falou:

- Chapeuzinho Vermelho, olha só para as lindas flores que crescem aqui em volta! Por que não olhas para os lados? Acho que nem ouves o mavioso canto dos passarinhos! Andas em frente como se fosses para a escola, e no entanto é tão alegre lá no meio do mato.

Chapeuzinho vermelho arregalou os olhos e quando viu os raios do sol dançando de lá para cá por entre as árvores, e como tudo estava tão cheio de flores,pensou:se eu levar um raminho de flores frescas para a vovó, ela ficará contente; ainda é tão cedo, que chegarei lá no tempo certo".

Então ela saiu do caminho e correu para o mato, à procura de flores. E quando apanhava uma, parecia-lhe que mais adiante havia outra mais bonita, e ela corria para colhê-la e se embrenhava cada vez mais pela floresta adentro.

O lobo, porém, foi direto para a casa da vovó e bateu na porta.

- Quem está aí fora?

- É Chapeuzinho Vermelho, que te traz bolo e vinho, abre!

- Aperta a maçaneta, - disse a vovó - eu estou muito fraca e não posso me levantar.

O lobo apertou a maçaneta, a porta se abriu, e ele foi, sem dizer uma palavra, direto para a cama da vovó e engoliu-a Depois, ele se vestiu com a roupa dela, pôs a sua toca na cabeça, deitou-se na cama e puxou o cortinado.

Chapeuzinho Vermelho, porém, correu atrás das flores, e quando juntou tantas que não podia carregar mais, lembrou-se da vovó e se pôs a caminho da sua casa. Admirou-se ao encontrar a porta aberta, e quando entrou, percebeu alguma coisa tão estranha lá dentro, que pensou: "Ai, meu Deus, sinto-me tão assustada, eu que sempre gosto tanto de visitar a vovó!" E ela gritou:

- Bom-dia!

Mas não recebeu resposta. Então ela se aproximou da cama e abriu as cortinas. Lá estava a vovó deitada, com a touca bem afundada na cabeça, e um aspecto muito esquisito.

- Ai, vovó, que orelhas grandes você tem!

- É para te ouvir melhor!

- Ai, vovó, que olhos grandes que você tem!

- É para te enxergar melhor!

- Ai, vovó, que mãos grandes que você tem!

- É para te agarrar melhor!

- Ai, vovó, que bocarra enorme que você tem!

- É para te devorar melhor!

- E nem bem o lobo disse isso, deu um pulo da cama e engoliu a pobre Chapeuzinho Vermelho.

Quando o lobo satisfez a sua vontade, deitou-se de novo na cama, adormeceu e começou a roncar muito alto. O caçador passou perto da casa e pensou: "como a velha está roncando hoje! Preciso ver se não lhe falta alguma coisa". Então ele entrou na casa, e quando olhou para a cama, viu que o lobo dormia nela.

- É aqui que eu te encontro, velho malfeitor, - disse ele, - há muito tempo que estou à tua procura.

Aí ele quis apontar a espingarda, mas lembrou-se de que o lobo podia ter devorado a vovó, e que ela ainda poderia ser salva. Por isso, ele não atirou, mas pegou uma tesoura e começou a abrir a barriga do lobo adormecido. E quando deu algumas tesouradas, viu logo o Vermelho do Chapeuzinho, e mais um par de tesouradas, e a menina saltou para fora e gritou:

- Ai, como eu fiquei assustada, como estava escuro lá dentro da barriga do lobo!

E aí também a velha avó saiu para fora ainda viva, mal conseguindo respirar. Mas Chapeuzinho Vermelho trouxe depressa umas grandes pedras, com as quais encheu a barriga do lobo. Quando ele acordou, quis fugir correndo, mas as pedras eram tão pesadas, que ele não pode se levantar e caiu morto.

Então os três ficaram contentíssimos. O caçador arrancou a pele do lobo e levou-a para casa, a vovó comeu o bolo e bebeu o vinho que Chapeuzinho Vermelho trouxera, e logo melhorou, mas Chapeuzinho Vermelho pensou: "Nunca mais eu sairei do caminho sozinha, para correr dentro do mato quando a mamãe me proibir de fazer isso". 
GUARDADOR DE PORCOS

Hans Christian Andersen

Era uma vez um príncipe pobre. Tinha ele um reino muito pequeno, mas suficientemente grande, apesar disso, para que pudesse casar, e casar ele queria.

Não deixava de ser atrevimento de sua parte perguntar à filha do Imperador: "Não me queres para marido?" Pois foi o que ele fez. No entanto, seu nome era famoso por toda a parte. Pelo menos umas cem princesas o teriam aceito de mão beijada, e ainda por cima agradecido. Ela, porém, a filha do Imperador, é que não quis saber disso.

Vamos ouvir o caso, que foi assim:

No túmulo do pai do príncipe crescia uma roseira, que era uma maravilha. Só floria de cinco em cinco anos, e, mesmo assim, só dava uma única rosa. Mas esta única rosa tinha uma fragrância tão doce, que, ao cheirá-la, esqueciam-se todas as preocupações e tristezas da vida. Tinha ainda o príncipe um rouxinol, cujo canto era como se todas as mais suaves melodias se reunissem em sua pequenina garganta. A rosa e o rouxinol iam ser dados de presente à princesa. Os dois foram colocados em grandes estojos de prata, e enviados ao palácio.

O Imperador fê-los trazer à sua presença, no grande salão onde a princesa estava brincando de "visitas" com suas damas de honor; não faziam outra coisa o dia inteiro, senão brincar. Quando viu os grandes estojos com os presentes, ela bateu palmas de alegria.

- Tomara que seja um gatinho! - disse.

Da caixa saiu a magnífica rosa.

- Que coisa mais bem feita! - exclamaram as damas de honor.

- É mais do que bem feita! - disse o Imperador.

A princesa , porém, tocou a rosa e começou a chorar.

- Horrível, papai! - disse ela. - A rosa não é artificial, é verdadeira!

- Ah! - lamentaram as damas de honor. - A rosa é verdadeira ...

- Vamos ver primeiro o que há no outro estojo, antes de nos zangarmos! - opinou o Imperador.

O rouxinol foi tirado da caixa. Seu canto era tão maravilhoso que não se lhe podia, no primeiro momento, pôr algum defeito.

- Superbe! Charmant ! - disseram as damas de honor, pois todas falavam francês, uma pior do que a outra.

- Como esse pássaro me faz lembrar a caixinha de música da Imperatriz - disse um velho cortesão. - Sim, sim... É o mesmo tom, direitinho. A mesma execução.

- É verdade! - disse o Imperador, e pôs-se a chorar como uma criança.

- Não me digam que esse pássaro é verdadeiro. Que não é artificial - disse a princesa.

- Sim, é um pássaro vivo, verdadeiro - disseram os que o tinham trazido.

- Então soltem esse passarinho. Que ele voe para onde quiser - decidiu a princesa, e não quis permitir que o príncipe se apresentasse.

O príncipe, porém, não desistia assim tão facilmente, nem se deixava desencorajar. Pintou o rosto com tinta marrom e preta, afundou bem o boné na cabeça e foi bater à por

ta do castelo.

- Bom dia, Imperador - disse ele. - Não me poderia dar um serviço aqui no castelo?

- São tantos os que procuram serviço aqui...- disse o Imperador. - Mas espera aí...Vamos ver uma coisa. Preciso de um rapaz que saiba tomar conta dos porcos. São muitos os porcos que possuo.

Assim foi o príncipe empregado como imperial guardador de porcos. Foi-lhe dado um quartinho ordinário, junto ao chiqueiro, e lá teve ele de ficar. Passou o dia inteiro trabalhando, e, ao cair da noite, terminara de fazer uma bonita panelinha, com guizos em volta. Logo que a panela fervia, os guizos soavam, tocando a velha melodia:

Ach, du lieber Augustin,

Alles ist weg, weg, weg!

Mas o requinte artístico da panela era outro: quando se colocava o dedo no vapor que dela saía, podia-se saber imediatamente pelo cheiro, que comida era feita em todos os fogões da cidade. Isto sim, era coisa bem melhor que uma simples rosa.

\footnotetext{
* Antiga canção satírica alemã, cujo texto, em tradução literal, é o seguinte:

Meu caro Agostinho,

Tudo se foi, se foi, se foi...

(Pron.: Arr du liber Augustin-Álles i-ss véc, véc, véc.) - Nota do tradutor
} 
A princesa, passeando com todas as damas de honor, ouviu a melodia e deteve-se toda contente. Era aquela a musica que ela também sabia tocar piano. Aliás, era a única que ela sabia, e, mesmo assim, tocava-a com um dedo só.

- É a cantiga que eu sei! - exclamou ela. - Então deve ser um porqueiro educado! Ouçam! Vão até lá e perguntem a ele quanto quer pelo instrumento.

Uma das damas de honor teve de ir lá, mas achou necessário calçar tamancos.

- Quanto queres por esta panela? - perguntou a dama de honor.

- Quero dez beijos da princesa - respondeu o guardador de porcos.

- Deus nos acuda! - disse a dama de honor.

- Sinto muito, mas não posso fazer por menos - retrucou o guardador de porcos.

- Então, que diz ele? - perguntou a princesa, quando a dama voltou.

- Nem o posso dizer - respondeu a dama de honor. - É horrível!

- Mas podes cochichar.

E ela cochichou.

- Sujeito malcriado! - disse a princesa.

Fez meia volta e foi-se embora. Mal andara, porém, um pedacinho, ouviu os guizos soarem, cristalinos:

Ach, du lieber Augustin,

Alles ist weg, weg, weg!

- Ouçam - disse a princesa. - Perguntem a ele se quer dez beijos de minhas damas de honor.

- Não, obrigado - respondeu o guardador de porcos.- Dez beijos da princesa, ou eu fíco com minha panela.

- Coisa mais chata! - disse a princesa. - Vocês fiquem na frente, para que ninguém nos possa ver.

As damas de honor fizeram roda em frente aos dois, espalharam bem os vestidos, o guardador de porcos recebeu dez beijos, e a princesa a panela.

Que festa! A panelinha teve de ferver o dia inteiro, e a noite também. Elas sabiam o que se cozinhava em quanto fogão havia em toda cidade, na casa do pobre e do rico, do camareiro-mor ou do sapateiro. As damas de honor pulavam, e batiam palmas de contentamento.

- Sabemos quem vai comer sopa doce e omelete! Sabemos quem vai ter, hoje, mingau e costelas de porco! Que coisa mais interessante!

- Muitíssimo interessante! - concordou a superior mestra de cerimônias.

- É... Mas bico calado nesse negocio, pois sou a filha do imperador!

- Deus nos livre e guarde! - disseram todas.

O guardador de porcos, isto é, o príncipe - não se sabia que ele não era um verdadeiro guardador de porcos - não deixava passar um dia sem fazer alguma coisa. Assim fabricou ele uma matraca. Quando se fazia girar essa matraca. Soavam todas as valsas, saltarelos e polcas que se conheciam desde a criação do mundo.

- Mas isso é superbe! - disse a princesa, quando passou por lá. - Nunca ouvi composição mais bela! Ouçam! Vão até lá e perguntem a ele quanto custa aquele instrumento. Mas nada de beijos!

- Pois ele quer justamente beijos, cem beijos da princesa - informou a dama de honor que fora fazer a pergunta.

- Acho que ele está maluco! - disse a princesa, e continuou o seu caminho.

Mas quando se afastou um pouquinho ficou parada.

- Deve-se estimular a arte - ponderou. -Sou a filha do imperador! Vão lá e digam a ele que receberá dez beijos meus, como ontem. O resto pode cobrar das minhas damas de honor.

- Mas nós... Beijarmos o porqueiro?...

Bobagem! - atalhou a princesa - Se eu o posso beijar, vocês também podem! Lembrem-se que eu as alimento e ainda lhes pago ordenado.

A dama de honor não teve outro remédio senão ir ver de novo o guardador de porcos.

- Cem beijos da princesa - declarou ele. - Ou cada um fica com o que é seu.

- Façam roda!- ordenou a princesa.

Todas as damas de honor fizeram uma roda em torno dos dois, e ela beijou a valer.

- Que ajuntamento será aquele lá no chiqueiro? - disse com os seus botões o Imperador, que saíra a sacada. Esfregou os olhos e pôs os óculos. - Mas são as damas de honor que estão metidas naquilo! Acho melhor eu ir até lá para ver o que é.

Enfiou os sapatos nos calcanhares (os sapatos do Imperador ele habitualmente os usava acalcanhados,como chinelos) e lá se foi.

E como ia depressa!

Chegando ao quintal, foi andando devagarinho. As damas de honor estavam tão ocupadas a contar os beijos, para que a transação fosse correta e o rapaz não os recebesse a mais, mas também não os recebesse a menos, que nem notaram a aproximação do Imperador. Este se ergueu nas pontas dos pés. 
- Que é isso! - exclamou ao ver quem eram as pessoas que se beijavam.

Bateu com chinelo na cabeça dos dois, exatamente no momento em que o guardador de porcos recebia o octagésimo-sexto beijo.

- Fora daqui! - gritou o Imperador, enfurecido, e ambos, a princesa e o imperial porqueiro, foram expulsos do reino.

Lá fora a princesa chorava, o guardador de porcos protestava, e chuva caía, de alargar.

- Ai de mim! Sou uma miserável! - exclamou a princesa. - Antes tivesse eu aceito o belo príncipe! Quanto sou infeliz, ai!

- O guardador de porcos escondeu-se atrás de uma árvore, limpou a tinta marrom e preta do rosto, deitou fora os andrajos, e apareceu em trajes de príncipe, tão formoso que a princesa se inclinou, respeitosa.

- Vim somente para desprezar-te, ouviste? - disse ele. - Não quiseste um príncipe honesto! Não gostaste da rosa e do rouxinol, mas beijaste o guardador de porcos em troca de uns brinquedos sem valor! Agora tens o que mereces!

E, dito isso, voltou ele para o seu reino, fechou a porta e aferrolhou. Só restava à princesa ficar do lado de fora, e cantar:

Ach, du lieber Augustin,

Alles ist weg, weg, weg... 


\section{B - LITERATURA NO CONTEXTO TRADICIONAL}

\section{A GALINHA RUIVA}

Paul Bilder.Ilustrações Eliana B. Brandão

A Galinha Ruiva achou uns grãos de trigo no terreiro e convidou seus amigos Porquinho, Patinho e Ratinho para ajudar a plantar. Assim teriam sempre comida. Eles não ajudaram e ela teve que plantar sozinha.

Assim que as plantinhas brotaram, a galinha voltou a convidar seus amiguinhos para ajudar a regar. Como ninguém se ofereceu, a galinha regou tudo sozinha, até que elas ficaram maduras e prontas para colher.

Então a galinha convidou o Porquinho para ajudar a colher o trigo e debulhar os grãos, e ele disse que não queria. E outra vez ela fez o trabalho sozinha, enquanto o malandrinho brincava despreocupadamente.

Quando chegou a hora de moer o trigo, ela foi procurar a ajuda do Ratinho, mas ele nem quis saber de conversa, e lá foi a Galinha Ruiva socar os grãos no pilão, até fazer uma farinha bem branca e fofinha.

Com toda aquela farinha, a galinha quis fazer pão, e chamou o Patinho para ajudar a fazer a massa. Ele nem parou de brincar. Disse para ela que não podia e a galinha teve que fazer o trabalho sozinha.

Nem adiantou pedir ajuda para assar o pão. Os três malandros nem quiseram ouvir. Ficaram dormindo debaixo de uma árvore, enquanto a Galinha Ruiva acendeu o fogo, esquentou o forno e colocou os pães para assar.

Quando os pães ficaram prontos, a galinha tirou um por um de dentro do forno, e foi acordar os preguiçosos.

- Quem quer me ajudar a comer os pães? - perguntou a nossa amiguinha.

Aquilo sim, os três queriam, mas a galinha nem deu importância para eles. Arrumou a mesa, cortou uma enorme fatia de pão e começou a comer. - Obrigada! - Falou. - Agora não precisa. Podem deixar que como sozinha.

TONICO BALANÇA-E-CAI

Heinrich Hoffmann

Seu pai falava e falava...

Mas Tonico costumava

(Vejam só que brincadeira!)

Balançar-se na cadeira

Que não era de balanço...

Era um vaivém sem descanso,

Durante o almoço e o jantar.

O pai cansou de ralhar.

- Bão Bambalão

Senhor capitão...

Quem não ouve o seu papai

Um dia... balança e cai

E foi o que sucedeu.

Certa vez, tanto mexeu,

Tanto inclinou para traz

Sua cadeira, que — zás!

Tonico, vendo o perigo,

Puxou a toalha consigo,

Foi tudo de cambulhada:

Vinho, pão, sopa, feijoada!

Que susto para o papai

E para a mamãe! Mas, si!

Para o Tonico, no chão,

Que formidável lição!

\section{O NEGRINHO}

Heinrich Hoffmann

Muito limpo e direitinho,

Passa na rua um negrinho,

Com seu guarda-sol aberto,

Gaspar, Luizinho e Roberto,

Que vivem constantemente

Caçoando de toda gente,

Mal vêem o pobre passar,

Começam logo a vaiar:

- Olhe o boneco de piche!

Macaquinho de azeviche!

Bobo alegre! Sai, tição...

Mestre Tomás o escrivão,

Ouvindo isso, chama os três

E diz-lhes: - Que mal vos fez

Esse pretinho infeliz

Que é preto porque Deus quis?

Mas começou outra vaia:

- Olhe o velhote de saia!

Fiau!... E com essa algazarra,

Um por um Tomás agarra

E, záz-traz! Mais que ligeiro

Mergulha os três no tinteiro

E eis cada qual mais pretinho,

Mais tinto que a tinta! E ao pé

Dos três vadios, até

Parece branco o negrinho! 


\section{O PORQUINHO DORMINHOCO}

Edna Groff. Deihl. Ilustrações A.E. Kennedy e Roberta Paflin

Era uma vez quatro porquinhos.

Os quatro porquinhos não iam fazer compras nem tratavam de ganhar a vida. Nunca saíam da casa onde tinham nascido.

Quando ainda eles eram pequeninos, o papai e a mamãe lhes puseram quatro nomes muito engraçados.

— Olhe como estes dois são pequenos! — dizia o papai. — Vamos chamá-los de Mingo e Tico?

— Excelente! — exclamou a mamãe. — Os nomes lhes assentam como luvas.

E em seguida apontou o terceiro bichinho, que dormia ao lado de Tico.

— Ficará bem o nome de Bolinha para esta filhinha rosada e redondinha? — disse a mamãe.

— Hum! É um belo nome! — concordou o papai. — É um nome que lhe assenta muito bem!

— Então ela ficará com esse nome mesmo! — disse a mamãe.

Depois começaram a pensar, a pensar. Que nome arranjariam para o seu quarto porquinho? E os olhinhos ficavam pequenininhos como casas de botões!

Nesse instante o quarto porquinho abriu um olho e suspirou, tornou a fechá-lo e caiu no sono outra vez. O papai sacudiu-o várias vezes, mas ele não acordou.

- Deus meu! - exclamou o papai. - Como é dorminhoco este nosso filho!

- Hum! - disse a mamãe. - Você encontrou o nome exato para ele. Este nosso bichinho se chamará Dorminhoco. Não é um nome muito, muito bonito, mas lhe assenta bem.

Todos os porquinhos, portanto, estavam batizados. Mingo e Tico não eram muito grandes nem muito fortes, mas em compensação, eram vivos e gozavam boa saúde.

Bolinha era uma leitoazinha asseada e de boas maneiras. Seu vestido sempre limpo. Sempre que ela acordava, lavava o rosto.

Mas Dorminhoco estava sempre dormindo. Só acordava para comer.

À medida que crescia, Dorminhoco, ao invés de melhorar, piorava. Chegou ao ponto de não se levantar nem para comer.

Para não ter de procurar o que comer, Dorminhoco só comia o que estava ao alcance do seu focinho, e caía novamente no sono.

Enquanto seus irmãozinhos brincavam ao sol, ele dormia e roncava num canto escuro do chiqueiro, onde toda a família morava.

E dia a dia se tornava mais gordo e preguiçoso.

Papai e mamãe eram muito trabalhadores. Levantavam-se bem cedo, todas as manhãs, antes de o fazendeiro lhes trazer comida, e enquanto a mamãe limpava a cozinha, o papai varria o quintal.

Mingo, Tico e Bolinha não precisavam ser chamados para o almoço. Chegavam sempre na horinha exata. Tinham bom apetite e não deixavam coisa alguma no prato.

Dorminhoco nem sequer almoçava.

Para falar a verdade, Dorminhoco às vezes não se levantava nem para jantar. Isso deixava a mamãe muito zangada, pois nunca podia varrer o canto do chiqueiro onde ele ficava. Seu filho não se levantava nem mesmo para que ela trocasse ou sacudisse a palha.

Os outros animais da fazenda gostavam muito de Mingo, Tico e Bolinha. Bé, o carneiro, Mu, a vaca, a égua e seu filhinho, o potro, passavam pelo chiqueiro, todas as manhãs, a caminho do pasto.

— Bééé! Bééé! — dizia o carneiro. - Bolinha é muito parecida com a mãe!

Era uma forma de dirigir um cumprimento delicado à mamãe dos quatro porquinhos.

— Múúú! Múúú! — dizia, por sua vez, a vaca ao papai dos porquinhos. — Os dois gêmeos se parecem muito com o senhor!

— Onde está o outro menino? — perguntava a égua. Ela admirava muito aquela enorme família, pois tinha um filho só.

— Está aí dentro, roncando - respondia a mamãe, com um ar bastante triste.

- Bem, um dia ele se arrependerá! — replicou a égua, num relincho.

Mingo, Tico e Bolinha eram crianças alegres. Davam-se com todos. Depois do almoço, abriam a porteira e corriam para fora.

— Não vão muito longe — recomendava-lhes sua mamãe. — Fiquem num lugar onde eu possa vê-los.

- Sim, senhora — respondiam os leitõezinhos.

A mamãe então entrava em casa.

— Dorminhoco! — Dorminhoco! Vá brincar com seus irmãos! Levante-se, ande!

— Nããão! — resmungava o porquinho, virando-se para o outro lado e tornando a dormir. Era tão preguiçoso, que nem gostava de falar.

E, por causa da preguiça, ele nem conhecia Plutão, um lindo cão preto que morava na mesma fazenda. 
Plutão gostava de implicar com os leitõezinhos, embora gostasse muito dele. Sempre os acompanhava latindo, quando iam brincar na estrada. Mas Mingo, Tico e Bolinha não se importavam com isso.

Como era costume uns porem apelidos nos outros, um dia os porquinhos apelidaram Plutão de "rabo de rato", porque o seu rabo era mesmo muito fino e comprido.

- O seu rabo não tem um belo anel como o nosso! - disse Tico.

- Meu rabo não tem rosquinha como os seus, mas em compensação, vocês não têm focinho elegante como o meu - respondeu Plutão.

Todos se riram. Era assim que eles brincavam e se entendiam.

Mas dorminhoco estava sempre dormindo e não conhecia Plutão senão de nome.

Muitas vezes Plutão escondia o seu osso no chiqueiro onde moravam os porquinhos. Eles eram tão bonzinhos que até o ajudavam a enterrar a comida que sobrava, como é do costume de todos os cachorros.

Plutão sempre mostrava aos porquinhos onde havia coisas boas para comer.

Em pagamento, quando os porquinhos achavam os ossos que Plutão escondia, não tocavam neles.

Certa manhã Dorminhoco acordou muito tarde. Não sobrara nada do almoço. Não havia leite na vasilha nem comida na gamela.

Dorminhoco ficou tão aborrecido, que rolou de raiva pelo chão. Estava com tamanha fome que seria capaz de comer qualquer coisa! E a única coisa que achou foi um osso escondido por Plutão.

Agarrou o osso e principiou a roê-lo gulosamente, mas, nesse momento, Plutão entrou no chiqueiro.

— Quer me dar o meu osso? — pediu o cão, delicadamente.

— Nããão! — grunhiu o porquinho, e pôs-se a roer o osso ainda mais depressa.

"Bem, não adianta ser delicado com esse porquinho" pensou Plutão. E, rosnando, saltou sobre Dorminhoco.

O porquinho procurou deitar-se sobre o osso, mas Plutão foi mais rápido que ele. Além de lhe tomar o osso, ainda lhe deu uma mordida na orelha!

A mamãe teve de tratar da orelha do Dorminhoco.

Por causa disso, mamãe ficou muito aborrecida com Plutão. Por mais duma semana não lhe permitiu entrar no chiqueiro.

Mas ficou também muito zangada com Dorminhoco.

— Seus irmãos e sua irmã sempre brincam com Plutão — dizia ela. — Mas você é tão indelicado que não sabe brincar com ninguém. Por que não se levanta cedo como todos nós?

— Nããão! — resmungou ele. E, em seguida, deitando-se de lado para não machucar a orelha, caiu no sono, no pátio do chiqueiro.

- Não sei o que vai ser dele - dizia a mamãe, suspirando, enquanto se afastava.

Certa manhã, Mingo, Tico e Bolinha foram à casa da fazenda.

— Venham conosco — disseram eles a Dorminhoco. — Na casa da fazenda há um menino que sempre nos dá comida. Vamos!

— Nããão! — grunhiu ele, baixinho, sem mesmo abrir os olhos.

- Corra, meu filho. Vá com eles! — pediu-lhe sua mamãe.

— Nããão! — respondeu ele, dessa vez bem alto.

Dorminhoco era mesmo muito mal-educado.

— Levante-se e vá com os outros — disse o papai, coçando-o com a bengala.

— Nããão! — berrou Dorminhoco, com uma voz de trovão.

E como era pesadão, dorminhoco e grosseiro, ninguém conseguiu movê-lo do lugar. Continuou a dormir, enquanto todos saíam correndo.

Era muito tarde quando acordou. Espreguiçou-se com toda a calma. Depois piscou e piscou os olhos. Finalmente, olhou em torno. Estava com fome. Não comera ainda nada naquele dia.

Ninguém estava em casa, mas, no pátio do chiqueiro, trepado no tapume, estava um menino com uma coisa amarela na cabeça.

"Deve ser o menino de que meus irmãos falaram" — pensou Dorminhoco. — "Talvez ele tenha alguma coisa que se coma".

Nesse momento, aquela coisa amarela que o menino trazia à cabeça, caiu no chão, perto de Dorminhoco.

- Obrigado - disse o porquinho.

E embora o menino gritasse que ele estava comendo o seu chapéu, Dorminhoco continuou a mastigar aquela coisa amarela.

Nesse momento, sua mamãe apareceu no pátio. Viu pedaços de palha que ainda restavam no chão e viu também uma longa tira de palha na boca do porquinho.

— Meu filho! - exclamou ela. - Você é tão ignorante, que nem sabe distinguir o que é comida do que é vestuário. Agora você vai ficar doente!

E isso aconteceu mesmo.

No meio da noite o papai precisou chamar o fazendeiro. 
O fazendeiro trouxe uma lanterna para poder examinar o porquinho. Deu-lhe uns remédios amargos para tomar e disse ao papai umas coisas bastante severas.

Depois não disse mais nada, e foi embora. Estava zangada porque fora acordado no meio da noite por causa dum porquinho preguiçoso e comilão.

O remédio curou o estômago doente de Dorminhoco, mas não lhe curou a preguiça.

Dorminhoco cada dia dormia mais. Cada dia roncava mais alto. Cada dia ficava mais e mais pesadão.

Um dia, logo após o café da manhã, o papai disse a Mingo, Tico e Bolinha:

- Meus filhos, tenho uma surpresa para vocês esta manhã.

- Vamos fazer um piquenique - acrescentou a mamãe. Vocês estão vendo a linda cestinha que compramos? Seu pai acordará Dorminhoco. Ele não pôde perder tão bom divertimento como este.

Mas, por mais que papai o puxasse e tentasse de todas as maneiras fazê-lo despertar, Dorminhoco continuou dormindo.

— Não quero desperdiçar o meu dia com este malandro! — disse o papai. — Ele que fique dormindo.

E foram fazer um piquenique. Mamãe e papai caminhavam lado a lado, enquanto Mingo, Tico e Bolinha corriam na frente.

A mamãe os olhava, satisfeita, e dizia ao marido: nhos!

- Será que existem crianças mais graciosas que as nossas? Nunca vi anéis tão bem feitos em outros rabi-

Nisso, olhou para trás e ficou triste:

— Que pena termos um filho tão dorminhoco! Que agradável piquenique ele vai perder!

- Hum! - grunhia o papai, caminhando pausadamente e levando a cestinha. — Não se aborreça. Algum dia ele mudará de vida.

Enfim, chegaram ao campo. Os leitõezinhos divertiram-se manhã toda, correndo e brincando de roda. Depois a mamãe foi preparar o almoço. Oh! Quanta comida! A mamãe dizia que gastariam a tarde toda para comer tudo aquilo!

Mal a mamãe acabara de dizer isso, verificou que já não restava nenhuma migalhinha para o pintarroxo pousado ali perto dele. Os porquinhos e seu papai estavam mesmo com muita fome!

A pata e os patinhos tinham ido ao campo para nadar no riacho. Depois do almoço convidaram os porquinhos. Não queriam nadar também?

Mas a mamãe não deixou. Disse ela:

- Os meus filhos estão acostumados a deitar um pouco depois de comer. Além disso, não trouxemos roupas de banho.

Então todos foram dormir um pouco e depois voltaram a brincar.

E enquanto eles se divertiam, Dorminhoco dormia. E roncava, roncava, roncava.

Como não havia ninguém que o amolasse, podia dormir à vontade.

Era a primeira vez que o deixavam dormir quanto quisesse.

Quando acordou, tudo estava em silêncio.

Olhou para a gamela: não havia coisa alguma para comer.

Enfiou o focinho na vasilha de leite: estava vazia.

— Mãeee! — berrou ele. Mas não teve resposta.

— Paiii! — tornou a berrar. E também não obteve resposta.

— Mingo! Tico! Bolinha! — berrou mais uma vez. E ninguém lhe respondeu.

E a fome cada vez apertava mais. le!"

"Tenho de dar um jeito" — pensou ele. — "Parece que ouvi falar num piquenique no campo... Vou atrás de-

Mas, como nunca saía do canto escuro do chiqueiro, não sabia onde ficava o lugar do piquenique.

Quando resolveu procurar o campo, esbarrou na porteira fechada da fazenda. Saltar por cima, não podia. Decidiu passar por baixo. Enfiou o focinho, depois a cabeça...

Mas quando quis passar os ombros também, viu que estava preso.

Gritou o mais alto que pôde:

— Socorro! Socorro! Socorro!

A pata vinha vindo com os seus patinhos, mas não pôde fazer nada para socorrê-lo.

Infelizmente, Dorminhoco era gordo demais. E os patinhos, vendo Dorminhoco entalado sob a porteira, não paravam mais de rir. Era tão engraçado!

Passou também uma galinha vermelha, mas não pôde ajudá-lo. A única coisa que podia fazer era rir.

— Chiii, porquinho! Dessa vez você está mal arranjado! — cacarejava ela, rindo a mais não poder.

Bé, o carneiro, $\mathrm{Mu}$, a vaca, a égua e seu potrinho voltavam do pasto. Além de nada poderem fazer por ele, ainda achavam graça no caso.

Até que enfim apareceu o menino da fazenda. Ao vê-lo preso sob a porteira, caiu na risada. Dorminhoco estava metade para dentro, metade para fora! 
Depois, parando de rir, o menino resolveu ajudar Dorminhoco. Primeiro tirou a barra de cima da porteira, depois a do meio e, finalmente, a de baixo.

- Agora você está livre, seu porquinho gordo e preguiçoso! — disse o menino. — Eu podia deixá-lo aí a noite inteira. Mas, apesar de você ter comido o meu chapéu, faço-lhe este favor!

Dorminhoco ficou bem aborrecido. Estava terrivelmente humilhado e, além disso, sentia uma danada duma dor de cabeça! Não compreendia por que todos haviam rido dele.

Nesse momento, papai, mamãe e os três porquinhos vinham voltando do piquenique.

Papai e mamãe pararam perto dele, admirados de encontrarem Dorminhoco acordado. Mingo, Tico e Bolinha nem pararam: correram pela estrada e passaram rapidamente sob a porteira.

Dorminhoco ficou pensativo. Como os seus irmãozinhos eram ágeis e como corriam! Quando deixou de olhar para eles, olhou com um olhar humilhado para a sua imensa barriga. Agora, sim, compreendia por que todos riam dele!

Tinha um corpo grande demais para pés tão pequeninos!

Aí perguntou à mamãe se podia brincar com Plutão perto de casa. Ela não lhe deu licença, porque Dorminhoco não sabia se comportar.

Bolinha brincava com Plutão e o cachorro não a mordia. Ela era muito esperta para que lhe acontecesse algo mau e sabia defender-se.

Dorminhoco olhou para a cesta vazia que seu papai trazia ao braço. Olhou depois para o campo onde se tinha realizado o piquenique. E então compreendeu quanto perdera por ser preguiçoso e dorminhoco.

Pegou a mão do seu papai sem dizer palavra. Apenas ia grunhindo enquanto subia a colina.

Quando se aproximavam de sua casa, ele disse:

— Pai, o sr. quer me acordar amanhã cedo?

O papai olhou para a mamãe. A mamãe sorriu. Ambos estavam com lágrimas nos olhos.

Agora tinham certeza de que nunca mais Dorminhoco ficaria dormindo e roncando, dormindo e roncando.

\section{O MENINO MAL CRIADO}

Autor desconhecido

- Noel, ajunte os seus brinquedos, disse-lhe a mãe; nós hoje vamos visitar Dona Leonor.

- Ora, mamãe! A senhora podia ir só, respondeu Noel. Eu estou brincando tão bem com o meu cavalinho de pau. Eu antes quero ficar.

- Um menino bem educado nunca diz: - Eu quero, disse a mãe. Obedeça à sua mãe e ao seu pai, sem resmungar.

Vamos, venha se vestir:

Noel, de muito mau humor, deixou o cavalo e acompanhou a mãe.

Dali a meia-hora chegaram à casa de dona Leonor.

Dona Leonor, ouvindo bater, foi abrir a porta e disse muito contente: - Oh! É a senhora Dona Emília! Como estimo vê-la! E o seu filhinho como vai? Como está Noel?

O senhor Noel respondeu muito baixinho e sem tirar o chapéu.

A sua mãe tirou-lhe o chapéu da cabeça e começou a conversar com Dona Leonor.

Enquanto as duas conversavam, Noel sentou-se sem ninguém mandar e cruzou as pernas em cima do assento da melhor cadeira.

Depois, atirou o chapéu sobre o sofá, assoou-se fazendo muito barulho, e enfiou os dedos no nariz.

E, no fim das contas, começou a abrir a boca, mesmo na frente de Dona Leonor.

A mãe que estava com os olhos em cima dele, não pôde mais aturar as suas grosserias e lhe disse: - Saia já daqui, meu senhor, não merece estar na sala. Vá-me esperar à porta.

E Noel, todo envergonhado, foi saindo e meteu-se num canto chorando e soluçando.

\section{A CARTEIRA PERDIDA}

Frei Idelfonso

Marcelo, um pequeno de doze anos, vinha para casa, quando viu no chão uma carteira.

Apanhou-a e abriu-a. Dentro estava uma nota de vinte cruzeiros.

Marcelo ficou contentíssimo. Começou a pensar no que podia comprar com aquele dinheiro; mas ao mesmo tempo lembrou-se de que sempre lhe tinham ensinado a não ficar com o que não era seu.

Decidiu-se então a levar a carteira ao comissário de polícia que o felicitou.

Marcelo, muito satisfeito, entrou em casa onde os pais o esperavam, já bastante inquietos com a sua demora.

Quando o menino contou o que se tinha passado, desculparam-no logo e a avó disse-lhe:

- Foi uma linda lição que praticaste, meu filho.

—Estamos orgulhosos por teres assim procedido, disse a mão em presença dos irmãos, abraçando. 
Só o pai se calou.

Este silêncio surpreendeu as irmãs. "Papai, não acha que Marcelo procedeu bem?” perguntou por fim a filha mais nova.

- Minha filha, respondeu o pai, é preciso não exagerar. O teu irmão, se não entregasse a carteira, teria procedido muito mal; mas entregando-a ao comissário de polícia, não fez mais do que o seu dever.

Marcelo corou respeitado.

- Mas afinal, papai, a carteira não tinha NOME. Quantos, no meu lugar, seriam tentados a ficar com ela!

- Esses seriam culpados, respondeu o pai.

Marcelo não insistiu, mas ficou descontente e pensou que era uma injustiça.

- Marcelo, disse a mãe, nós já almoçamos; mas eu guardei o teu almoço.

E pousou sobre a mesa um prato de com carne.

Marcelo dispunha-se a principiar a almoçar quando se ouviu a campanha da porta.

- Vai ver quem é, Marcelo, disse o pai.

$\mathrm{O}$ pequeno obedeceu.

Era uma senhora que tinha enganado o número da porta.

Marcelo indicou-lhe a casa que ela procurava, e voltou para a sala de jantar.

Ficou surpreendido! O seu prato estava vazio.

Aproveitando a ausência de Marcelo, o gato levou a carne para debaixo da mesa onde estava acabando de comê-la. "O gato comeu o meu almoço", gritou Marcelo furioso; "Ladrão"!

- Como a carne não tinha nome, o gato entendeu que devia comê-la, disse com muita calma o pai.

E enquanto Marcelo ficava vermelho como um camarão, continua aquele:

- Chamas então de ladrão o gato por comer o que lhe não pertence, não é verdade?

Marcelo compreendeu a lição.

- Meu pai, disse ele então; perdoe-me; fui tolo e vaidoso, ainda há pouco; com efeito, não fiz mais do que o meu dever, entregando o dinheiro.

— Ainda bem, que o reconheceste, meu filho, respondeu o pai abraçando.

\section{BITU, O CARNEIRINHO SUJO}

Maria Thereza Cunha de Giacomo. Ilustrações Darcy Penteado

À beira de uma estrada florida moravam dois carneirinhos: Liró e Bitu. Eram irmãos e muito amigos. Brincavam juntos e juntos passavam horas conversando. Tinham uma casa pequenina, de paredes cor-de-rosa, janelas verdes e telhado bem vermelhinho.

Seus pais eram muito bonzinhos. Deixavam que os dois irmãos fossem alegres e se divertissem brincando. Só não queriam que eles fizessem artes e se sujassem. Diziam sempre:

— Sejam bem comportados! Não manchem esse lindo pêlozinho tão branco!...

Mas acontece, que às vezes, os irmãozinhos são muito diferentes... E era assim com esses dois:

Liró era muito asseadinho. Só gostava de brincar no gramado do jardim. Corria atrás dos insetos que pousavam nas flores, pulava entre as pedrinhas limpas e roliças. Bitu, ao contrário, era muito sujinho. Vivia brincando com terra, lambuzando-se com a água enlameada das poças. Mesmo depois do banho ele ia brincar nos lugares mais sujos do jardim. Liró chamava:

— Bitu, você vai se sujar nas poças! Cuidado, volte!

Mas o carneirinho nem se importava. Metia as patinhas na lama e respingava seu pêlozinho tão sedoso e alvo.

Liró tinha um focinho tão limpinho que dava gosto olhar... Mas Bitu era aquela tristeza: sempre malhado de sujo, todo marrom de terra!

Um dia, os dois irmãozinhos brincavam no jardim. Bitu convidou:

- Vamos correr na estrada?

Mas Liró, mais ajuizado, respondeu:

— Nada disso, Bitu. Ontem choveu muito. Lá fora só há poças d’água!

— Pois disso mesmo é que gosto! Vou brincar e já! Fique aí você, se quiser!

Disse isso e saiu aos pulos, pela porteira. Logo encontrou lama e água suja.

- Olé, que coisa boa! Vou pular nestas poças d'água!

Dito e feito. A água estava fresquinha, apesar de suja. Ele achou uma delícia molhar ali as patinhas e as pernas!...

Liró viu o irmão ir-se afastando, pela estrada barrenta. Lá longe, Bitu desapareceu numa curva. O carneirinho limpo ficou brincando sozinho em seu lindo jardim.

Bitu levou todo o dia metido nas valas e nas poças da estrada. Depois, o sol secou tudo: a água na terra e a lama no carneirinho. Assim, a sujeira se agarrou em seu pêlo branquinho. Bitu ficou marrom, de tão sujo! 
Começava a anoitecer. Os grilinhos saltitavam no mato, cantando o seu cric-cri delicado. Uma estrelinha já piscava no céu, espiando entre as nuvens rosadas. Bitu, esquecido da vida, ainda pulava na poeira. E comia as graminhas verdes que encontrava na beira da estrada. Assim, tão sujo na luz meio apagada da tarde, mais parecia um burrico que um carneirinho de verdade!

Um velho que passava por ali deu com ele.

Não enxergava direito e queria ganhar dinheiro para comprar uns óculos. Tinha uma horta bem tratada. Mas não podia levar sozinho os legumes e as verduras para a feira.

Viu Bitu e pensou: "Ali está um burrinho abandonado, coitadinho! E muito bom para me ajudar. Bem que poderia levar minhas hortaliças à feira... É pequeno, mas serve muito bem!”.

— Béé!Béé!...

Mas o velho, que se chamava Seu Maneco, não estranhou. Achou que aquilo era voz de burrinho novo e levou Bitu para casa. Este ia todo o tempo gritando:

- Deixa-me homem! Quero voltar para casa!

Mas nada adiantava. O homem não entendia o que o carneirinho dizia. Pensava até que se sentia muito feliz por encontrar quem tomasse conta dele.

E lá se foram os dois pela estrada a fora... O velhinho todo contente. E o carneirinho muito assustado...

Liró, vendo que o tempo passava e o irmãozinho não aparecia, ficou assustado. Correu a falar com sua mamãe. Foi um rebuliço! Dona Ovelha, sempre tão calma, ficou muito aflita! Foi logo falar com o pai de Bitu. E procuraram o fillhinho o dia todo e ainda uma porção de tempo...

Como não o encontrassem, ficaram muito tristes. Pensaram que ele se havia afogado em alguma poça maior! Nem se lembraram de ir à horta de Seu Maneco. Era tão longe! Como podiam adivinhar que o filho lá estava?

Bitu foi preso num cercadinho e lá passou toda a noite. Apesar de gostar das poças, já estava se sentindo mal, com tanta sujeira. Suspirava por um banho! E chorava baixinho: — Béé, béé...

No dia seguinte, Seu Maneco amarrou duas cestas, cheias de verdura, nas costas do carneirinho. Depois, tocou para a feira. Na rua todo o mundo olhava aquele velho puxando por uma corda um carneirinho tão sujo!

Além de triste, Bitu caminhava envergonhadíssimo! Sabia muito bem como estava feio. Mas Seu Maneco não percebia isso.

E lá iam os dois! O pobre do Bitu não podia fazer nada, preso com aquela corda em volta do pescoço. Seguia de cabeça baixa, com as pesadas cestas às costas. Quando passou pela porta de sua casa inda baliu alto e tristemente. Mas ninguém, nem Liró, pôde ouvir. Estavam todos longe, à procura do carneirinho desaparecido.

$\mathrm{Na}$ feira, Seu Maneco vendeu tudo que trouxera! Cada pé de alface ou pacote de tomates que lhe compravam, era para ele uma grande alegria! Isso porque o velhinho ia juntando mais dinheiro. Logo poderia comprar os óculos de que necessitava tanto!

Quando acabou a feira, voltaram os dois para casa. Durante todo o tempo Bitu viera triste e cabisbaixo. Na feira estivera amarrado a um toco, perto da barraca do Seu Maneco. No meio de tanta gente e tanto barulho, ficara tonto. Todos gritavam chamando a freguesia. O homem do peixe dizia:

- Olhem a sardinha! Saída agora do mar!

E o homem das frutas:

— Olhem as laranjas maduras! Bananas, maçãs, pêras!

Todos andavam por entre as barraquinhas de cores. Bitu podia ser pisado, pobrezinho.

Às vezes passavam tão pertinho que ele tinha de encolher depressa as patinhas! E os carrinhos de feira? Quase atropelavam o pobre do carneirinho. E não adiantava choramingar:

- Béé... Béé... Béé...

Quem poderia ouvir aquela vozinha fraca, no meio de tanto barulho?

Que dia agitado! Seu Maneco, todo animado com sua venda, nem prestava atenção ao companheirinho. Queria juntar bastante dinheiro e só nisso pensava. E Bitu tinha de conformar-se mesmo.

Agora, que voltava para casa, vinha cansado. Nunca em sua vida andara com tanto peso às costas. E nunca ficara no meio de tanta gente e de tanto barulho. A volta, portanto, era bem melhor. As cestas, com a venda dos legumes todos, vinham vazias. Estavam leves. E Bitu, apesar de triste, vinha bem aliviado. E achava graça da alegria de Seu Maneco que cantarolava: "Com pouco mais já compro uns óculos"...

Mal chegou, comeu tanto capim como nunca comera em toda a sua vida. Sentia todo o corpo cansado. Mais cedo que os outros dias, logo se foi deitar num amontoado de capim seco que havia num canto da casa. Antes de dormir pensou muito na sua casinha, lá longe. E quase chorou, com saudades de Liró.

Levou muitos dias assim. Já não tinha esperanças de escapar. Seu Maneco tinha sempre muito cuidado em amarrá-lo com segurança. Sempre voltava à feira com as verduras. E seu dono, cada vez mais, aumentava seu dinheirinho.

Além disso, Bitu diariamente trabalhava com Seu Maneco no preparo da horta. Carregava terra de um lado para outro, trazia os baldes com água para as plantas, levava as enxadas, as pás e o ancinho que Seu Maneco punha em suas costas, na cesta. 
Um dia, de volta de seu trabalho, Bitu lembrou-se de Liró e sentiu mais saudades que nunca! Estava desolado em seu cercadinho...

- Bem dizia meu irmãozinho! Se eu estivesse limpo, Seu Maneco, não ia me confundir com um burrinho. Imagine: eu, burrinho! Bem poderia agora estar em casa! Seria tão bom se eu pudesse tomar um banho!

Mas qual! A água que havia ali mal dava para beber. Era muito pouquinha, numa lata!

De repente, Bitu percebeu uma coisa! Seria verdade? Seu dono esquecera a porteira do cercadinho aberta! Era só uma corrida... E logo ali estava a estrada! Num instante estaria em casa! Mais que depressa olhou para os lados: ninguém havia por ali. Deu um pulinho e... pronto! Estava livre! Saiu correndo, correndo, correndo...

Mas... lá adiante, parou. Por que seria? É que Bitu se lembrara de uma coisa: "Se eu fugir, quem vai levar as verduras à feira para o velhinho? Ele não enxerga bem! Sem vender suas hortaliças não terá dinheiro. E sem dinheiro não poderá comprar seus óculos!”

Bitu não sabia o que fazer. Queria tanto voltar para casa! Mas tinha pena do coitado do Seu Maneco! Se agora, com sua ajuda, ele não juntasse dinheiro para os óculos, quando poderia fazê-lo? Ninguém gostava de ajudá-lo!

Pensou, pensou... E, como tinha bom coração, não podia deixar Seu Maneco assim de uma hora para outra. Afinal, muito devagarinho, voltou para seu cercado. Queria ajudar Seu Maneco a comprar os óculos!

No dia seguinte, o velhinho encontrou Bitu no cercado. E, quando viu a porteira aberta, pensou:

— Que perigo! Esse burrinho até podia ter fugido... Preciso ter mais cuidado!

E lá se foram os dois para o trabalho na feira. Venderam, como sempre, todas as verduras que haviam levado.

Bitu já andava aflito por um banho! Pensava sempre em Liró, tão limpinho. Mas, apesar de tudo, já sentia prazer em ajudar seu dono e gostava de seu trabalho. Seu Maneco, aos poucos, ia juntando dinheiro para seus óculos.

Um dia levaram para a feira as cestas cheias de verduras e de tomates muito vermelhinhos e grandes. Era a melhor colheita de Seu Maneco. Nunca o velhinho conseguira tantos tomates, tanta alface. E como estavam bonitos os seus legumes! Todos quiseram comprar., foi um movimento nunca visto na feira. Num instante as cestas ficaram vazias! E que bom preço pagaram por tudo!

Pronto! Com tanto dinheiro o velhinho já podia comprar seus óculos! Foi para casa cantarolando! Que alegria! De novo ia enxergar como os outros. Poderia ver melhor as florinhas na trepadeira, os pássaros nas ramadas, as letras do jornal, as estrelas do céu, e até os rostinhos das crianças!...

Deixou Bitu no cercadinho. Arrumou sua melhor roupa e foi para a cidade...

Bitu estava com o coração palpitando! Afinal, seu dono ia perceber o engano que cometera. Vendo bem, como os outros homens, logo ia saber a verdade: que ele era apenas um carneirinho sujo e não um burrinho marrom!

O dia custou muito a passar. Bitu já estava ansioso. Não podia parar quieto. Corria de um lado para outro, dentro do cercado!

Afinal, Seu Maneco apareceu. Vinha animado e contente! Sobre seu nariz estavam os óculos novinhos!

Passou pelo cercado para agradecer ao burrinho a sua ajuda. Mas viu apenas um carneirinho sujo! Ficou admirado! Tirou os óculos, esfregou as mãos nos olhos, colocou-os outra vez e exclamou:

— Pobrezinho!... Então você era um carneirinho?!... Quanto peso levou, coitado! E sempre tão bonzinho!

Entrou no cercadinho, abraçou Bitu e levou-o para um bom banho. O carneirinho estava radiante! Como ficou lindinho, com o pêlo alvo e sedoso! Parecia um floco macio de algodão!...

Depois, Seu Maneco soltou o carneirinho e disse:

— Muito obrigado, meu bom amiguinho! Não vou mais prender você, não!...

Bitu estava muito alegre. Deu uns pinotes e chegou perto do Seu Maneco. Amigavelmente roçou seu corpo nas pernas do velhinho. Depois, numa corrida louca, sumiu pela estrada, a caminho de casa!

E ia pensado:

- Nunca mais vou me sujar nas poças! Agora sei muito bem como é gostoso um banho... E como é bom ficar limpinho e cheiroso.

Corria, corria e depressa chegou à sua casa.

Ao ver o irmão, Liró e os pais nem podiam acreditar! Abraçaram Bitu e ficaram muito felizes. Mas, depois quiseram saber toda a história...

Quase choraram ao saber dos sofrimentos do carneirinho! Mas agora ele estava novamente entre os pais e o querido irmãozinho.

Desde esse dia Seu Maneco sempre passava pela casinha da estrada florida. E ia fazer festas para dois carneirinhos felizes e lindos: Liró e Bitu!... 
O GALO DE CASA

Autor desconhecido

Uma dona de casa despertava todas as manhãs suas duas empregadas, logo depois do canto do galo.

As moças, zangadas, resmungaram:

- Se não fosse aquele maldito galo, poderíamos dormir um pouco mais.

E assim dizendo, mataram o galo.

A dona da casa, que sempre se acordava muito cedo, não tendo mais o controle das horas, chamava as duas empregadas mais cedo ainda, e por vezes, à meia noite.

Quem o pouco não sabe suportar,

Um dia mal maior, há de então encontrar.

\section{CHIQUINHO O MEXE-MEXE}

Angelino Cotoweski. Ilustrações de Joselito

Chiquinho não podia ver qualquer coisa sem pegá-la ou tocar-lhe. Quando passava na sala de jantar diante do grande relógio da parede, Chiquinho mexia sempre no pêndulo, de modo que o relógio parava.

Se apanhava o relógio do pai, logo o abria e empurrava os ponteiros para direita e para a esquerda; assim o relógio ficava desarranjado.

Passando pelo Totó, o cãozinho da casa, puxava-lhe o rabo e, por isso, já levara uma forte dentada na mão; mas "mexe-mexe" não se emendava.

Um dia, indo à cozinha, abriu a torneira da caldeira do fogão e queimou-se com água fervendo. Logo desatou em alto choro, mas ainda desta vez, o terrível Chiquinho não se corrigiu.

Um outro dia, não há ainda muito tempo, o incorrigível "mexe-mexe" foi passar uns tempos na fazenda de um tio. Aí desamarrou um bote que estava preso à margem do açude e saltou dentro dele.

$\mathrm{O}$ bote foi levado para o meio do açude, que era muito fundo.

O nosso "mexe-mexe", longe das margens, sozinho dentro do bote, reconhecendo o perigo, começou a gritar cheio de medo.

Se os operários da fazenda não tivessem socorrido, Chiquinho teria sido vítima de seu mau costume.

Evitarei o que é mal, e farei o que é bom.

\section{VOCABULÁRIO}

Apanhava pegava

Desarranjo estragado

Incorrigível impossível de se corrigir

Bote barco

Açude represa, tanque

\section{QUESTIONÁRIO}

Por que tinha o Chiquinho o apelido de "mexe-mexe"?

Que fazia o Chiquinho ao passar pela sala de jantar?

E quando apanhava o relógio do pai?

Que lhe fez um dia o Totó?

Que aconteceu a Chiquinho na cozinha?

Que fez Chiquinho, certa vez, na fazenda do tio?

Que teria acontecido a Chiquinho?

Quem o socorreu?

\section{NOÇÕES DE GRAMÁTICA}

Acento agudo

Acento agudo (') é o sinal que indica vogal aberta.

Estas palavras têm acento agudo:

Café - chapéu - cipó - sofá - régua - paletó

\section{EXERCÍCIO}

Copiar do trecho de leitura todas as palavras com acento agudo.

Redação:

Invente uma pequena história sobre a gravura abaixo: 


\begin{tabular}{|l|l|l|}
\hline $\begin{array}{c}\text { Menino brincando na areia } \\
\text { da praia }\end{array}$ & $\begin{array}{l}\text { Menino na praia (de pé) com } \\
\text { baldinho de areia na mão }\end{array}$ & $\begin{array}{l}\text { Uma criança na cama. Ao la- } \\
\text { do uma mulher com termômetro } \\
\text { na mão }\end{array}$ \\
\hline
\end{tabular}

\section{LIÇÃO MERECIDA}

Angelino Cotoweski. Ilustrações de Joselito

Pedrinho não gostava de miolo de pão; só comia crosta. Um dia, ao almoço, o pai percebeu que ele atirava fora o miolo do pedaço de pão que lhe havia dado.

O pai de Pedrinho não disse nada.

Ao jantar partiu pão para todos, menos para Pedrinho. O menino, supondo que fosse um esquecimento disse:

- Papai, eu ainda não recebi pão.

- Hoje não te darei pão, pois sempre o atiras fora!

Pedrinho calou-se, envergonhado. Tudo aquilo que ele comeu sem pão, lhe pareceu menos saboroso.

No dia seguinte, ao almoço, Pedrinho esperou em vão que lhe dessem pão. Ao jantar o pai lhe deu um grande pedaço de miolo; Pedrinho comeu-o com muito prazer e achou-o excelente.

Daí por diante, Pedrinho nunca mais atirou fora o miolo do pão que lhe davam às refeições.

O pão é o mais precioso dos alimentos.

\section{VOCABULÁRIO}

Miolo de pão. parte que fica dentro do pão

Crosta casca, côdea

Supondo pensando

Saboroso gostoso

Excelente muito bom

\section{QUESTIONÁRIO}

Pedrinho gostava de miolo de pão?

Que aconteceu um dia no almoço?

Que fez o pai de Pedrinho?

Que aconteceu na hora do jantar?

Que respondeu o pai?

Pedrinho recebeu pão no dia seguinte?

Daí por diante Pedrinho comia miolo de pão?

\section{NOÇÕES DE GRAMÁTICA}

$\mathrm{C}$ ou Q

$\mathrm{Ca}, \mathrm{Co}, \mathrm{Cu}$, Que, Qui

C com som de K só escreve antes de A, O, U. Antes de E, I escreve QU

\section{EXERCÍCIO}

Copiar e colocar C ou Q onde for preciso:

$\begin{array}{ll}\text { —adeia } & \text { _ente } \\ \text { _eijo } & \text { _opo } \\ \text { _ampo } & \text { bos_e } \\ \text { _intal } & \text { bamelo } \\ \text { _orda } & \text { _ortina } \\ \text { pe_eno } & \text { _eima }\end{array}$

FORMAR SENTENÇAS ONDE ENTREM AS PALAVRAS SEGUINTES:
$\begin{array}{ll}\text { Miolo de pão } & \text { excelente } \\ \text { Saboroso } & \text { refeições }\end{array}$ 


\section{C - LITERATURA NO CONTEXTO CONTEMPORÂNEO}

\section{O EQUILIBRISTA}

Fernanda Lopes Almeida. Ilustrações Fernando de Castro Lopes

Era uma vez um equilibrista.

Vivia em cima de um fio, sobre um abismo.

Tinha nascido numa casa construída sobre o fio.

E já tinha nascido avisado de que a casa podia desmoronar a qualquer momento.

- Acho que vou me mudar..

\begin{tabular}{|c|}
\hline AVISO \\
Esta casa \\
Está \\
Por um fio! \\
\hline
\end{tabular}

Mas logo percebeu que não havia nenhum outro lugar para ele morar.

O equilibrista ainda era bem jovem quando descobriu que ele mesmo é que tinha de ir inventando o que acontecia com o fio.

\section{- MEU DEUS! QUE RESPONSABILIDADE!}

Se queria ter uma festa, tinha que fabricar a festa com o fio.

- Não há nenhuma festa pronta para as pessoas ali na esquina.

- Não? Então vou fazer uma.

Convite
Para minha
Festa.
Eu que fiz.

Se queria ir à Europa, tinha que construir a viagem para a Europa.

- Tem aí uma viagem para a Europa já viajada?

— Engraçadinho! Não quer mais nada, não?

Ele então transformava o fio em viagem. E a verdade é que não se arrependia:

-É incrível quanta coisa se pode fazer com este fio!

Para ter amigos, o equilibrista tinha que procurar outros equilibristas.

As pessoas desequilibristas não queriam ser amigas dele:

— Que idéia, essa, de viver assim!

-É louco!

O equilibrista ainda tentava se defender:

- A idéia não foi minha! Já nasci assim!

Mas as pessoas não queriam ouvir:

- Imagine se vou acreditar numa mentira dessas!

Elas juravam que ninguém nasce assim.

O equilibrista, então, ia se encontrar com outros equilibristas.

- Como vai?

- Vou-me equilibrando dentro do possível.

O equilibrista ficava um pouco assustado com a conversa dos desequilibristas:

- Como vai?

— Muito mal. Meu carro enguiçou.

- Como vai?

- Muito bem. Minha caderneta rendeu juros.

— Mas então quem vai mal e quem vai bem não são vocês. São o carro e a caderneta! 
— Há! Há! Há! Olha o bobo!

— Qual é a diferença?

Os equilibristas também podiam ir muito mal ou muito bem. Mas a conversa deles dava para entender:

- Como vai?

— Vou mal. Estou com um elefante na cabeça.

- Como vai?

- Vou bem. Hoje, pela primeira vez, eu verdadeiramente vi um beija-flor.

É verdade que, às vezes, o equilibrista ficava morrendo de inveja de quem tinha um chão. Mesmo que fosse feinho.

"Chão de cimento é feio, mas que comodidade."

$\mathrm{Na}$ mesma hora se desequilibrava e caía.

Enquanto caía, gritava:

\section{— ONDE FICA O CHÃO?}

Mas só recebia respostas malcriadas:

— Está claro que fica embaixo. Não enxerga?

- Mas embaixo de quê?

- Olhe, não tenho tempo para conversas bobas. Passe Bem.

$\mathrm{O}$ equilibrista fazia um esforço danado para saber onde era embaixo.

Afinal desistia.

- O jeito é ir desenrolando o meu fio.

E desenrolava o melhor que podia.

- Pensando bem, gosto de ser equilibrista.

- Pensando bem, como é dura a vida de equilibrista!

- Pensando melhor, é ruim e bom. Tudo misturado.

De vez em quando o equilibrista dava uma paradinha e olhava para trás:

- Puxa! Meu chão fui eu mesmo que fiz!

Mas tinha que ser uma paradinha rápida.

— Meu avô sempre dizia: — Quem pára demais pra pensar, acaba sem saber andar.

O equilibrista pensava no justo tempo e anda no justo tempo.

— E aprendi fazer isso com o tempo há! há!

Assim foi chegando ao fim do fio.

Antes de despedir-se, disse:

— Respeitáveis outras pessoas! Esta vida de equilibrista é perigosa, mas muito interessante. Por mim, fiz o que podia e achei que valeu a pena. Adeus.

Umas pessoas concordaram. Outras, não.

— Eu também acho muito interessante! Viva o equilibrista!

- Eu não acho graça nenhuma! Fora! Fora!

- Eu acho que vale a pena! Vale muito a pena!

— Não vale a pena, nada! Eu acho uma boa droga!

$\mathrm{O}$ equilibrista deu um risinho:

— Justamente o interessante é que cada um acha o que quer.

\section{O CURUMIM QUE VIROU GIGANTE}

Joel Rufino dos Santos. Ilustrações Lúcia Lacourt

Esta história foi Baíra

quem me contou.

O piá Tarumã queria que

queria ter uma irmãzinha.

Mas não nascia. Ele pedia

pro pai dele, pedia pra mãe.

Até que desistiu.

Não é bem que desistiu.

Ele pegou imaginar como seria a irmãzinha que ele queria. Imaginou, imaginou, imaginou.

A mãe cuidando dela.

A maninha brincando de ciranda.

A mana já grande comendo araçá com as amiguinhas.

Belo dia, Tarumã foi pescar mais com os outros. Cada um flechou um peixe.

Tarumã que flechou dois.

- Pra quem é esse peixe? - perguntaram a ele.

— É pra minha maninha - Tarumã respondeu.

Ninguém sabia que tinha nascido irmã de Tarumã.

- Então, deixa eu levar este tapiti pra ela um curumim falou.

— Leva - Tarumã falou.

- Então, deixa eu levar esta igaçaba

pra ela - outro curumim falou.

- Leva - Tarumã falou.

— Então, deixa eu levar esta flor 
pra ela - outro curumim falou.

— Leva - Tarumã falou.

Levaram. Chegando que chegando na oca de Tarumã,

ele disse: - Vocês esperam aqui,

que eu vou chamar minha maninha.

Os curumins esperaram.

Tarumã apareceu?

Qual nada.

Noutro dia, eles encontraram

Tarumã. — Cadê sua irmã?

- perguntaram a ele.

— Ah, gente! - explicou Tarumã.

- Ela estava sentadinha me

esperando. De repente chegou

um monte de abelhas. Mais

abelhas que estrelas no céu...

— Aí? - perguntou

um curumim.

— Minha irmãzinha saiu

correndo. As abelhas ferroando

ela! Mas ninguém acreditou

em Tarumã.

Vai que, belo dia,

eles foram pegar cajuí no mato.

Cada um pegou um pouquinho.

Tarumã pegou um montão.

- Pra quem é tanto cajuí? - perguntaram.

-É pra minha maninha - Tarumã respondeu.

Ninguém acreditava que tinha

nascido irmã de Tarumã.

- Então, deixa eu levar esse

tié-piranga pra ela - um

curumim falou.

— Leva - Tarumã falou.

— Então, deixa eu levar esta liticó

pra ela - outro curumim falou.

— Leva - Tarumã falou.

- Então, deixa eu levar estas pitangas

pra ela - outro curumim falou.

— Leva - Tarumã falou.
Levaram. Chegandinho na oca

de Tarumã, ele foi dizendo:

- Vocês esperam aqui, que eu vou

acordar minha maninha.

Os curumins esperaram.

Jacaré apareceu?

Nem Tarumã.

Noutro dia ele encontrou os amigos.

— Cadê sua irmã? - perguntaram.

- Ah, gente! - ele explicou.

- Ela estava deitadinha me esperando.

De repente apareceu um monte de formigas.

Mais formigas que areia de praia...

- Aí? - perguntou um curumim.

- Carregaram a esteira.

— Está bem. Mas cadê sua irmã?

Tarumã esperou um minuto.

Coçou a cabeça. Depois respondeu:

- Foi junto.

— Junto com quem?

- Com as formigas que carregaram

a esteira - explicou Tarumã.

Só que ninguém acreditou mais.

Tinha era irmã nenhuma!...

Tarumã ficou com vergonha.

Ela aumentou, aumentou,

virou vergonhão.

Aí ele saiu pelo mundão.

Andou que andou.

Sem coragem de voltar.

Na beira-beira do mar,

Tarumã deitou de costas.

Esticou os pés, as mãos,

o pescoço. Virou um gigante.

Quando você chega no Rio de Janeiro, você não vê um gigante deitado, não? Os pés são o Corcovado.

É Tarumã. Bem em cima da cara dele tem uma estrela. Mas não é estrela não, gente. O que Tarumã está olhando é a irmãzinha dele. 
OS DEZ AMIGOS

ZIRALDO

Era uma vez um dedo

tão pequenininho

que se chamava Mínimo.

Ele tinha quatro irmãozinhos

que se chamavam: Anular

Médio, Indicador

e Polegar.

O Mínimo era muito brincalhão

- um dedo muito levado -

e vivia se metendo

onde não era chamado.

Um dia, ele teve uma grande idéia:

- Vamos brincar de teatrinho?

E falou, pra completar:

— Eu vou ser o Anãozinho!

- Deixem que eu seja o Rei!

gritou o Anular,

cheio de anéis de ouro

que ele adorava usar!

- Pois eu vou ser um guerreiro! falou o Médio, botando um dedal na cabeça pra fingir de capacete.

— Pois eu vou ser o guia da floresta! falou o Indicador que sabia mostrar os caminhos.

- Pois, muito bem - falou, com voz grossa, o Polegar eu vou ser o vilão.

E engrossando mais a voz:

- Podem me chamar de Dedão!

E, dito isto, prendeu

os quatro amiguinhos

no fundo da mão:

- Quero ver vocês saírem desta prisão!

Foi aí que ele ouviu uma ordem: - Pare!
Solte seus amigos!

Em mão fechada,

eles podem morrer sufocados!

— Quem são vocês?

perguntou o Polegar,

fazendo voz de vilão.

— Nós somos os dedos

da outra mão!

- Meu nome é Mindinho!

falou o menor de todos.

- E eu sou Seu-Vizinho!

falou o vizinho do Mindinho.

— Eu sou o Pai-de-Todos!

falou o grandão

que ficava bem no meio

da outra mão.

— Eu sou o Fura-Bolos!

falou o que tinha cara

de provador de doces

e de furador de bolos.

- E eu sou o Mata-Piolhos!

falou o que tinha

nome, voz e carinha

de vilão.

— Muito prazer!

disseram todos

logo, logo se enturmando

cada um se perguntando:

- Nós vamos brincar de quê?

- Vamos brincar de massinha?

- Vamos tocar um piano!

- Vamos brincar de inventar!

Todos tinham mil idéias

e falavam sem parar.

Mas, o maioral da turma

falou mais alto que todos

que o ouviram com atenção:

- Nós somos todos os dedos

de cada uma das mãos. Então!

Por que ficar preocupados

em saber do quê brincar?

É só parar pra pensar:

nós todos juntos, juntinhos,

do maior ao mais miúdo...

... podemos brincar de tudo! 


\section{A HISTÓRIA DA BOLINHA CURIOSA-}

Edson Gabriel Garcia

A história da bolinha curiosa foi publicada pela primeira vez na Folhinha de São Paulo, 1980.

Depois, ficou guardada durante três anos numa pasta verde de elástico.

Apesar disso a curiosidade continuou viva, firme e acesa.

E está de volta.

Edson

A história da bolinha curiosa começa no meio. Não no meio da página, nem no meio da vida.

A história da bolinha curiosa começa no meio de um caminho.

Num caminho onde a bolinha andava todos os dias.

De lá pra cá...

De cá pra lá...

Sempre o mesmo caminho estreito e curto, sempre as mesmas alegrias poucas, sempre as mesmas tristezas medidas e as mesmas brincadeiras.

E tanto a bolinha cansou-se do caminho estreito e curto que começou a pensar nas coisas que poderia haver fora do caminho.

Encheu-se de curiosidade.

Tanta curiosidade que não coube no caminho estreito e curto.

Foi então que a bolinha saiu fora do seu caminho.

E viu um caminho bem maior, sem fim, cheio de outras bolinhas.

E viu outros companheiros que ela jamais poderia imaginar.

Descobriu que tudo, fora do seu caminho estreito e curto, pode-se vestir com cores bonitas e diferentes.

Quando a noite chegou, ela descansou satisfeita, de olhos fechados, pensando no que havia conhecido.

Depois resolveu voltar e falar ao seu caminho sobre tudo que havia visto e conhecido.

Foi chegando... foi chegando... e tentou falar ao caminho.

Mas o caminho era estreito demais e não acreditava em nada que estava fora dele.

Por isso a bolinha ficou falando sozinha.

Pra lá e pra cá.

Pra cá e pra lá.

Até que percebeu que ela já não mais cabia no caminho.

E saiu de vez.

E quando se viu livre do caminho, sentiu-se um pouco perdida e atrapalhada, sem o caminho a mostrar-lhe a direção.

Aos poucos, ela entendeu-se e pôs-se a pensar numa nova vida, sem caminhos estreitos e curtos.

E imaginou-se vestida com todas as cores.

E sonhou com o brilho da Lua, com a companhia das Estrelas e com o calor do Sol.

E pensou-se grande e vazia, pronta para conhecer o mundo.

E imaginou-se num mundo grande, sem muro e sem direção traçados, vivendo a vida que a curiosidade indicava.

\section{SE AS COISAS FOSSEM MÃES}

Sylvia Orthof. Ilustrações Ana Raquel

Se a lua fosse mãe, seria mãe das estrelas,

o céu seria sua casa, casa das estrelas belas.

Se a sereia fosse mãe, seria mãe dos peixinhos,

o mar seria um jardim e os barcos seus caminhos.

Se a casa fosse mãe, seria a mãe das janelas,

conversaria com a lua sobre as crianças estrelas,

falaria de receitas, pastéis de vento, quindins,

emprestaria a cozinha pra lua fazer pudins!

Se a terra fosse mãe, seria a mãe das sementes,

pois mãe é tudo que abraça, acha graça e ama a gente.

Se uma fada fosse mãe, seria a mãe da alegria,

toda mãe é um pouco fada... Nossa mãe fada seria.

Se uma bruxa fosse mãe,

seria mamãe gozada:

seria a mãe das vassouras, da Família Vassourada! 
Se a chaleira fosse mãe, seria a mãe da água fervida, faria chá e remédio para as doenças da vida.

Se a mesa fosse mãe, as filhas, sendo cadeiras, sentariam comportadas, teriam "boas maneiras".

Cada mãe é diferente: mãe verdadeira, ou postiça, mãe vovó e mãe titia, Maria, Filó, Francisca, (escreva o nome da sua mãe, ou tia, ou quem lhe cria)

GERTRUDES, MALVINA, ALICE, toda mãe é como eu disse.

Dona Mamãe ralha e beija, erra, acerta, arruma a mesa, cozinha, escreve, trabalha fora, ri, esquece, lembra e chora, traz remédio e sobremesa...

Tem até pai que é "tipo mãe"... esse, então, é uma beleza!

\section{O REINO DAS BORBOLETAS BRANCAS}

Marli Assunção Gomes Pereira. Ilustrações Teruyo Kajiki de Souza

Nas viagens que fiz pelo mundo das fantasias, visitei um reino muito interessante:

O Reino das Borboletas Brancas!

Lá tudo era branco, e o que não era, ficava num cantinho esquecido.

As graciosas borboletas só beijavam as flores brancas que, orgulhosamente, tremulavam à brisa fresca. dos.

Um dia, nasceu no reino uma linda borboletinha que, por sua candura e mimo, chamou a si a atenção de to-

Até sua majestade, a rainha, foi vê-la.

A linda borboleta ia crescendo muito saudável, alva, sempre cercada de brancos carinhos.

Ao dar seu primeiro passeio, ela se deslumbrou com o esvoaçar das borboletas por sobre as flores, porém apenas sobre as brancas.

Percebeu a tristeza das outras...

— Oh! Como são lindas, diferentes!

Curiosa, se perguntava:

- Por que as borboletas só beijam as flores brancas? Por que as coloridas estão plantadas em cantos tão distantes e reservados? Será que minhas irmãs não percebem a beleza dessas flores?

No caminho de volta, reparou em uma flor azul.

— Que esplendor! Que pétalas! Que perfume!

Ah! Ela não resistiria. As outras que beijassem as brancas.

Pousou na flor e nela depositou um terno beijo.

Que surpresa! A flor, que nunca havia sido beijada, ao contato de sua boquinha, ficou ainda mais bela.

Em sinal de agradecimento, a flor deixou rolar de suas pétalas uma gotinha ainda fresca de orvalho para as asas de sua gentil admiradora.

A gotinha se espalhou e tingiu as asas da borboleta de um azul muito delicado.

O susto foi geral!

- De onde surgiu essa borboleta azul?

- Como entrou aqui?

- Quem permitiu?

Foi difícil esclarecer.

Seus pais repreenderam-na, mas gostaram da nova cor.

Logo, outras borboletinhas, encantadas com a cor da amiguinha, seguiram seu exemplo. Começaram a beijar flores amarelas, rosas, vermelhas. E ganhavam também gotinhas de orvalho e se tornavam amarelas, rosas, vermelhas.. te.

Havia, ainda, as que beijavam flores diversas e se tornavam multicoloridas, de um tom delicado, transparen-

Que alvoroço! O que estava acontecendo? Precisavam informar as ministras do reino, que, por sua vez, informariam a rainha. vidências.

- Majestade, venha ver! O reino das borboletas brancas está desaparecendo! Precisamos tomar sérias pro-

A rainha saiu às ruas e, boquiaberta, olhava suas pequenas súditas num bailado alegre e colorido pelo ar. 
Nunca vira nada tão belo!

As ministras esbravejavam e exigiam providências.

A esvoaçante população se dividia.

Uns aplaudindo... outros, sem saber o que fazer.

As borboletas coloridas caprichavam no bailado. Alternavam-se, ora azuis, amarelas, rosas, vermelhas, multicores, fazendo referências à rainha.

Não me lembro quanto tempo durou o espetáculo, mas quando parti, o reino já não tinha o mesmo nome.

Agora se chamava Reino das Borboletas Coloridas.

\section{TIMÓTEO, O TATU POETA}

Rosana Rios.Ilustrações Semirámis Nery Paterno

Timóteo vivia cavando buracos como faz todo tatu. Passava o dia tranqüilo na toca, de vez em quando caçando uma minhoca ou formiga que desse o azar de aparecer. Só à noite é que seguia pelo túnel principal até sair da mata.

Às vezes parava para conversar com Tatu Tonho, na saída da toca. Tonho e outros tatus mais velhos viviam com preguiça de sair, mesmo para beber água.

- Sair?... - dizia Madame Tatua, uma das mais enjoadas. — é muito perigoso!

— Tem razão! - concordava Tatuí Otávio. - Melhor ficar aqui no fundo da toca, onde os caçadores não chegam.

- Até logo, Timóteo ! Quando você voltar, nos conta como vai a mata lá em cima - despedia-se Tonho. E se ajeitava sobre as folhas secas que formavam uma cama macia, abrigando muitos tatus preguiçosos. Lá ficavam eles, conversando sobre a vida, enquanto Timóteo e os tatus mais jovens saíam pelo mundo afora.

Procuravam água, frutinhas, raízes e também formigas. Protegidos pelas cascas grossas, Timóteo, seus amigos Teca Tatinha e os irmãos Tonico e Tilico atacavam juntos os formigueiros grandes.

Mas não naquela noite. Teca Tatinha estava de visita a Madame Tatua, que era sua tia. Tonico e Tilico tinham ido para longe, à procura de raízes de mandioca. Ao sair da toca, Timóteo se viu sozinho e quis se meter a corajoso: resolveu ir beber água numa nascente perto do morro, onde quase nunca os tatus chegavam.

Não era difícil chegar lá. O problema era atravessar uma clareira cheia de pedras, lugar perigoso, pois não havia plantas que escondessem um tatu desprevenido dos inimigos. Onças, jaguatiricas e, pior de tudo, caçadores.

Timóteo, um tatu moço, metido a valente e cheio de idéias, nem pensou em perigo e foi direto para a clareira, já sentindo na boca o gostinho de água fresca da nascente.

Teve sorte, é verdade: não havia caçadores nem onças famintas por perto. O que ele não sabia é que o perigo maior não estava na terra, e sim no céu... A Lua, nos últimos dias em quarto crescente, estava ficando cheia. $\mathrm{E}$ assim que Timóteo entrou na clareira vazia, ela saiu de trás das nuvens. Seu clarão forte brilhava como nunca!

Foi a primeira vez que Timóteo viu a lua cheia. Nas noites em que saía, costumava ficar entre os arbustos, olhando para o chão à procura de comida. Mas naquela noite, ah!... A luz do luar fazia brilhar as pedras, as folhas das árvores, o fio de água nascendo além da clareira.

$\mathrm{O}$ tatu parou ali, indiferente ao fato de se tornar visível a todos os outros bichos. Pegou o luar em cheio na casca, nas patas, nos olhos. Esqueceu-se até de beber água!... Só quando ouviu alguns pássaros começando a se agitar - sinal de dia chegando - é que deu meia-volta e seguiu direto para a toca.

Tão distraído estava que passou por Tatu Tonho sem notá-lo.

— Ué, Tatu Timóteo! Voltou só agora da mata? - estranhou Tonho.

- Voltei - explicou ele, por causa do luar. Era tão bonito que eu não podia deixar de olhar!

- Cuidado, rapaz! - alertou o mais velho. - Lua cheia mexe com a cabeça da gente. Cuidado para não ficar aluado!

Era tarde para avisar. Não sei se foi a Lua, o ar da noite, ou alguma doença desconhecida para os tatus. O que eu sei é que depois daquela noite Timóteo nunca mais foi o mesmo...

Teca Tatinha foi a primeira a perceber, quando passou ao lado da toca em que Timóteo dormia, em seu amontoado de folhas. Como sempre fazia, puxou conversa:

- Olá, Timóteo! Caçou muito a noite passada?

Timóteo, ainda com brilho nos olhos, respondeu:

- Quem é que podia caçar

debaixo daquele luar?...

Teca achou graça:

— Caçar? Luar? Que engraçado, Timóteo! Você rimou!

Tatu Timóteo estranhou:

- Rimei? O que é isso?

Não conheço esse serviço. 
— Rimou outra vez! - riu-se ela. — Isso com serviço.

Timóteo finalmente entendeu:

- Ah! Isso que é rimar?

As palavras combinar,

uma poesia formar!

A essa altura, Teca já estava desconfiada:

— Você está brincando comigo, Tatu Timóteo!

Mas ele olhava para ela mais sério do que nunca:

- Quem disse que é brincadeira?

Não brinco dessa maneira.

— Pois então converse sozinho! Muito engraçado, ficar falando tudo com rimas...

Irritada, ela deixou o amigo na toca e foi embora pelo túnel. Não sabia que aquelas rimas não saíam de propósito. Timóteo não conseguia falar nada sem rimar. Fosse com quem fosse, a qualquer hora do dia ou da noite, dentro ou fora da toca, era só abrir a boca que saíam versos.

Timóteo acabou se acostumando. Mesmo depois de passado o efeito da lua cheia, ele estava tão acostumado com a poesia que não parava mais de rimar. Achava aquilo tão bom! E passava a maior parte do tempo procurando rimas diferentes:

- Boa tarde, Tatu Tonho!

Está um dia medonho...

Chove tanto lá na mata

que o rio virou cascata!

Quando encontrava os amigos Tilico e Tonico, fazia propaganda dos efeitos da lua cheia:

-Não deixem de ir passear

lá na clareira, ao luar.

Lua cheia quando brilha

é mesmo uma maravilha!

Os outros achavam aquilo um pouco estranho, mas engraçado. Era bom para quebrar a monotonia da toca. Foi então que a história chegou aos ouvidos da Madame Tatua.

A princípio ela não acreditou. Ora, um tatu fazendo poesia! Só podia ser brincadeira. Tatus jovens gostam de pregar peças nos mais velhos. Era preciso esperar que a mania passasse.

É claro que não passou. Meses depois, Tatu Timóteo não só não deixava de rimar, como estava ensinando os filhotes das tocas próximas a fazer rimas também! A fama do Tatu Poeta ia se espalhando pela mata.

Tanta poesia era demais para Madame Tatua. Resolveu agir. Foi entrando em todos os túneis vizinhos, à procura dos tatus mais velhos.

— Isso é um absurdo! - repetia ela para quem quisesse ouvir. — Onde já se viu um tatu rimar? Nunca houve tal coisa em nossa comunidade!

Os tatus velhos cochichavam entre si:

- Ela tem razão.

— Desde que o velho Tatu Teodoro cavou o primeiro buraco na mata, nunca se viu um tatu rebelde como esse!

- Daqui a pouco vão mudar todo o modo de vida dos tatus!

- E vão querer que a gente pule de galho em galho, feito macaco!

Apenas Tatu Tonho, que conhecia Timóteo desde pequenininho, defendia a mania de seu amigo.

—Deixem o Timóteo em paz! - dizia. — ele não incomoda ninguém com as sua rimas.

Madame Tatua estremecia tanto que quase rachava a casca:

— Incomoda, sim! Tatus não fazem poesia. Certo?

- Certo! - respondiam os tatus.

— Timóteo faz poesia, logo não é um tatu como os outros. Certo?

- Certo! - repetia o coro.

Portanto - arrematava Madame Tatua, com o focinho empinado -, ele deve ser proibido de rimar para não atrapalhar os outros!

- CERTO!!! - gritavam todos.

E Tatu Tonho não conseguia convencer ninguém de que Timóteo tinha o direito de rimar.

Na semana seguinte, na entrada do túnel principal, de onde saíam muitos buracos de tatus, apareceu um aviso. Escavado em casca de árvore por unhas de tatu, dizia assim:

\section{É PROIBIDO RIMAR. \\ TATUS POETAS SERÃO EXPULSOS DA MATA. ASSINADO:}


É bom explicar que o Conselho era formado por todos os tatus mais velhos e por Madame Tatua! Logo que o aviso apareceu, Tatu Tonho achou melhor ir conversar com Timóteo. Encontrou-o na toca, terminando uma poesia que fazia para o aniversário da Teca Tatinha.

Como vai, Tatu Tonho?

Por que esse ar tristonho?

Tonho suspirou profundamente. A coisa ia muito mal. Até para cumprimentar os amigos ele rimava!

- Olhe, Tatu Timóteo - começou ele -, você não soube do aviso que foi colocado na entrada das tocas? O Conselho resolveu proibir os tatus de fazer rimas.

- Timóteo não se preocupou muito com aquilo:

- Rimar é tão divertido.

- Não pode ser proibido!

— Eu sei, mas os tatus mais velhos não pensam assim. Acham que não se deve mudar o que os tatus vêm fazendo desde que apareceram. Mudanças, para eles, são perigosas!

Timóteo ainda não estava acreditando:

- Pois desde o meu nascimento

eu mudo a todo momento!

Antes mamava, e agora

caço pra comer lá fora.

Mesmo se quiser parar

de a toda hora rimar,

eu sei que não poderia.

Abro a boca e sai poesia!

-Pense bem, Timóteo - continuou Tonho - , fazer rimas é mudança demais para velhos tatus acomodados. Se você não parar, eles vão expulsá-lo daqui. Pense bem e pare com essas rimas!

Timóteo não podia parar. O costume de procurar rimas já fazia parte dele. Sentia-se feliz quando terminava uma frase e a poesia saía limpa, natural, gostosa.

-Por que querem proibir

alguém de se divertir?

Não sei o que faço agora,

se eles me mandam embora.

Gosto da mata, da toca,

de formiga e de mandioca,

de beber água no rio,

de dormir quando faz frio.

Mas, mais do que a Luz do dia,

gosto de fazer poesia!

$E$ vou viver magoado

tendo que ficar calado...

A proibição era pra valer. Os tatus jovens, que achavam divertidas as rimas de Timóteo, tratavam de ficar bem quietos e não irritar os mais velhos. Ninguém queria ir embora da mata. Para onde iriam? Nasceram e cresceram ali. Tinham que se preocupar somente em procurar comida e água, além de escapar dos perigos. Se Timóteo queira ser diferente, o problema era dele!

Aos poucos, o Tatu foi ficando sozinho em seu canto, remoendo suas rimas lá por dentro, já que não podia colocá-las para fora. Ele quase não falava, com medo de se esquecer e, de repente, deixar escapar um verso. Porque só um bastaria para chegar aos ouvidos de Madame Tatua e causar sua expulsão.

Foram dias muito tristes. Nem por brincadeira algum tatu se atrevia a falar duas palavras com final parecido...

Magro, desanimado, cansado de tanto ficar com a boca fechada, certa noite Tatu Timóteo saiu da toca para beber água. Com muito cuidado para não encontrar ninguém, ele cavou um novo túnel de saída e foi parar bem perto da clareira, onde tinha visto a lua cheia pela primeira vez. Esperou que as nuvens se afastassem e olhou a Lua. Não era cheia, estava ainda em quarto crescente. Ali, sozinho, sem nenhum tatu por perto, Timóteo finalmente pôde falar:

-Ah, minha amiga Lua!

Sei que foi por culpa sua

que eu fiquei com a mania

de sempre fazer poesia.

Agora vivo calado,

sozinho e desanimado,

sem poder olhar pra cima, 
segurando a minha rima.

Vou acabar doente

sem ir pra trás ou pra frente,

esquecido no meu canto

por causa do seu encanto.

A Lua não respondia, mas uma voz conhecida cochichou por trás dele:

- Ei, Timóteo! Quero falar com você!

Era a voz de Teca Tatinha. Escondida atrás das pedras da clareira, ela estivera ali ouvindo a conversa de Timóteo com a Lua, decidida a fazer alguma coisa para ajudá-lo. Aquela situação não podia continuar!

- O que você quer de mim?

Não basta eu estar assim,

desanimado e cansado,

de tanto ficar calado?

Teca Tatinha não o deixou terminar:

— Chega de desânimo, Timóteo! Eu tive uma idéia para resolver seu problema. Aliás, nosso problema! Se eles proibiram você de rimar, daqui a pouco vão começar a proibir mais coisas. Tatus quando se metem a mandar, não param mais!

-Não sei, não minha querida..

Essa é uma guerra perdida!

- Pois nós vamos acabar com a guerra - afirmou Teca. - Com a ajuda da lua cheia, vamos mostrar a eles que rimar não é crime!

Os dois voltaram animados para a toca. Nos dias que se seguiram, estiveram ocupados em fazer uma coisa muito estranha: cavar pequenos buracos em vários pontos do chão da mata. Outros tatus amigos, como Tonico e Tilico, também ajudaram. E quando chegou o fim de semana, estavam todos ansiosos esperando a noite descer.

Madame Tatua foi para seu canto da toca, como fazia todas as noites, esperar pelos tatus do Conselho. Ajeitou-se sobre as folhas, sem perceber que, no alto da toca, um buraco fazia ligação com o mundo lá fora...

A reunião do Conselho começou.

Era lua cheia outra vez! O clarão da Lua, forte, brincalhão, entrou mata adentro, passando por entre os galhos das árvores e chegando ao chão. Não demorou muito para que entrasse nos buracos escavados pelos tatuzinhos. O plano de Teca começou a funcionar!

A luz atingiu em cheio os velhos tatus, que conversavam. Madame Tatua sentiu algo esquisito acontecendo. Olhou para cima e viu a luz que entrava:

- Buracos no teto da toca?!

Quem é que teve coragem

de fazer essa bobagem?

Tatu Tonho, quieto em seu canto, sorriu divertido:

— Ué, Madame Tatua. Foi impressão minha ou a senhora rimou?

- Bem, eu não sei direito..

Nunca falei desse jeito!

Mas sinto coisas estranhas

aqui nas minhas entranhas!

Tatu Otávio, também recebendo a claridade, disse:

- Ela rimou, é verdade.

Mas que infelicidade!

A confusão se instalou na toca. Todos os velhos tatus começaram a falar rimando. Madame Tatua não se conformava, e Tatu Tonho ria, ria com prazer.

- Nós não queremos rimar,

mas não podemos parar!

Isto aqui não é possivel,

é a coisa mais incrível!

Será uma epidemia,

um ataque de poesia?!

Era o efeito da lua cheia, desta vez atacando os tatus do Conselho. Eles tentaram de tudo para parar de rimar, reclamaram, sapatearam, mas não podiam fazer nada. A poesia era mais forte!

$\mathrm{O}$ aviso riscado a unha de tatu em casca de árvore desapareceu pouco tempo depois. Não se podia proibir uma coisa que quase todos faziam!

A lua cheia passou, e com ela a magia. Mas havia deixado em todos a prova de que rimar era gostoso. Mesmo os tatus que tinham mais medo de mudanças acabaram esquecendo de implicar com os poetas. 
Quanto a Tatu Timóteo, o primeiro tatu poeta da mata, voltou a fazer suas poesias sem preocupações. Ele e Teca até inventaram um jogo que ficou muito conhecido por ali: o Campeonato de Rimas para Tatus. Quem conseguisse lembrar mais palavras que rimassem ganharia o Campeonato - e o título de Poeta da Mata! Quem diria...

Proibir não adianta

quando a gente dança e canta,

quando a gente se alivia

fazendo história e poesia.

Seja bicho ou seja gente,

quem quiser ser diferente

tem que ter sempre o direito

de escolher qual é o seu jeito!

E quem quiser ser teimoso,

impedindo o que é gostoso,

acaba é arrependido

de dizer que é proibido.

Pois, mais dia, menos dia,

também vai fazer poesia!

\section{O LOBO E O CARNEIRO NO SONHO DA MENINA}

Marina Colasanti

Era uma vez um lobo.

Era uma vez uma menina que tinha medo do lobo.

O lobo morava no sonho da menina.

Quando a menina dizia que não queria ir dormir porque tinha medo do lobo, a mãe respondia:

- Bobagem, menina, sonho é sonho. Esse lobo não existe.

Ela ainda estava tentando se convencer quando, espiando por trás da árvore do sonho para ver se o lobo andava ali perto, deu de cara com um carneirinho.

Era branco e cacheado como todos os carneirinhos de sonho.

-Que bom você estar morando aqui também - disse ela.

E logo ficaram amigos.

Passado algum tempo, porém num dia em que o carneirinho pastava margaridas, levando a menina na outra ponta da fita que ela tinha lhe posto no pescoço, apareceu o lobo.

- Sonho é sonho - pensou a menina para se tranqüilizar.

E repetiu as palavras da mãe:

- Esse lobo não existe.

Assustado, o carneirinho tremia com a boca cheia de flores.

— Mas se o lobo não existe - pensou a menina - o carneirinho também não.

E ela gostava tanto do carneirinho...

Então, pegou depressa o amigo no colo, firmou os pés no chão. E esperou o lobo.

Nisso o despertador tocou e ela teve que acordar para ir ao colégio.

Ficou o dia inteiro preocupada por ter deixado o carneiro sozinho com o lobo.

À noite, assim que acabou de jantar, deu um beijo na mãe e foi dormir correndo para socorrê-lo.

Chegou ao sonho esbaforida. E mais esbaforida ficou vendo o lobo encolhido num canto com o rabo entre as pernas e as orelhas murchas, enquanto o carneirinho eriçado rosnava para ele por entre os pequenos dentes amarelos.

A menina nunca tinha visto um carneiro feroz.

O lobo também não.

Nem mesmo o carneiro sabia do seu ódio. Rosnava e avançava para o lobo, afundando os cascos no capim do sonho.

De susto, a menina acordou.

- Agora - pensou na segurança da cama -, vou ter dois medos de ir dormir. Do lobo. E do carneiro.

Porém, à noite, a mãe não quis ouvir histórias. Deu oito horas, cama. A menina fez tudo para não pegar no sono. Pensou até que bom seria poder, pelo menos por uma vez, ir passar a noite no sonho de alguma amiga.

Mas, por mais que se esforçasse, teve, de repente, a impressão de ver um carneiro pular uma cerca, depois outro. E ao contar o terceiro carneiro, catrapum!

Foi ela que pulou para dentro do sonho.

Tudo quieto. Silêncio.

O carneirinho não veio recebê-la. O lobo estava escondido em alguma prega daquele manso dormir. 
— Mas onde ficar? - pensou a menina. — Se passeio na grama, o carneirinho é capaz de pular-me em cima. Se vou para o mato, o lobo me come.

Depressa, subiu na árvore. Escolheu um galho, sentou-se. Não era muito confortável. A posição doía aqui e ali. Procurou outra, encostou-se no tronco. Mas era duro e machucava-lhe as costas. E, ainda por cima, formigas, que ela nunca tinha percebido, cismavam agora de escalar suas pernas.

Vira e vira, mexe e mexe, a noite foi passando, incômoda, dura, cheia de asperezas. E áspera foi ficando também a menina por dentro. Áspera e inchada. Inchada de raiva.

Até que, como se percebesse que lá fora do sonho já raiava o dia, deu um pulo até o chão. E, mãozinhas na cintura, gritou bem alto:

— Este sonho é meeeeuuuuuuu!

Tão alto, que acordou.

Ainda faltava tempo para o despertador tocar. Mas dessa vez a menina percebeu que iria ao colégio sem pressa, sem aflição nenhuma. E, à noite, deitaria à hora que bem entendesse, sem medo. Sem ter que ir para o alto da árvore. Porque, afinal, aquele sonho era dela.

E, de agora em diante, ela é que iria mandar, botar lobos e carneiros nos seus lugares. Nem que fosse preciso, vez ou outra, dar umas boas rosnadas e mostrar os dentes.

\section{AVENTAL QUE O VENTO LEVA}

Ana Maria Machado. Ilustrações Helena Alexandrino

Corina menina brincava com cor.

Com tinta, com lama, com folha, com flor.

Quer dizer, gostava de sentar na terra, misturar com água, fazer papinha de tudo o que encontrasse, pintar com os dedos como se fosse pincel.

Para não sujar o vestido, usava sempre avental. Branco, com alça de babado e bolso bordado.

Todo dia era a mesma coisa: o avental saía de casa limpo e bem passado.

Acabava o dia sujo, todo amarrotado.

E quase sempre, lá pelo fim da tarde, Corina acabava tirando. Para pintar o sete, sem nada que atrapalhasse.

Um dia, ela tirou o avental e pendurou num galho. Quando foi olhar, não estava mais lá. O vento levou? Devia ter levado, porque lá não estava.

- Vento, você ventou o avento? - perguntou Corina.

Ele não respondeu. Então, ela saiu procurando. Lá longe, no alto do morro, viu uma mancha branca. Para ir lá no alto, Corina pediu ajuda.

- Cabrito, me leva até lá?

Cabrito levou.

Pula-que-pula, chegaram lá perto e viram.

A mancha branca não era avental nenhum.

Era só um fiapo de nuvem. Mas a nuvem deu uma ajuda:

— Eu acho que vi. Quando chovi, vi um branquinho no meio da mata. Quem sabe se era o avental?

Explicou direitinho onde era. Corina menina foi procurar.

- Gavião, me leva até lá?

Gavião levou.

Voa-que-voa, saíram do alto do morro, passaram perto das nuvens, chegaram lá perto e viram. A mancha branca não era avental nenhum.

Era só um fiapo de paina, numa paineira enorme que já tinha dado flor.

Mas a paina deu uma ajuda:

— Eu acho que vi. Quando ventou, balancei bem no alto e vi um branquinho lá onde o rio se despenca. Quem sabe se era o avental?

Explicou direitinho onde era. Corina menina foi procurar.

- Macaco, me leva até lá?

Macaco levou.

Cambalhota-que-cambalhota, saíram do alto da árvore, chegaram lá perto e viram.

A mancha branca não era avental nenhum.

Era só um fiapo d'água, cachoeira caindo fininha do alto da pedra.

Mas a cachoeira deu uma ajuda:

- Eu acho que vi. A lavadeira esteve aí embaixo, na curva do rio, e lavou um avental lindo na água clara. Depois levou para a menina mais levada da casa mais florida do campo.

Corina menina foi procurar.

- Pato, me leva até lá?

Pato levou. 
Nada que nada, anda que anda, chegaram lá perto e viram.

Era a casa dela mesma.

Na gaveta do armário do quarto da casa, lavado, passado e dobrado, estava guardado o avental.

Com alça de babado e bolso bordado.

Branco como a nuvem.

Leve como a paina.

Limpo como a cachoeira.

E Corina menina não precisou procurar mais. Agora era só tomar banho na espuma branca do sabonete e ficar limpa e cheirosa, como o avental.

Depois, comer e dormir. Para acordar descansada e poder pintar o sete no dia seguinte.

E quem gostar de artes que se prepare e pinte também.

\section{QUE LUGAR É ESTE?}

Maurício Veneza

Onde estou?

Que lugar é este?

O coelho olhou em volta e não viu ninguém.

Como ficar parado não ia adiantar nada, saiu andando para qualquer lado.

E logo encontrou o rei.

- Bom-dia! Ou será boa-noite? Não dá pra saber.

- Boa-tarde! - respondeu o rei.

- Quem é o senhor?

— Não está vendo? Eu sou o rei.

- Rei deste lugar?

— Não. Eu sou o rei das cartas.

Apareceram as cartas.

- Bom-dia! - disse a primeira carta.

- Boa-tarde! - disse a segunda carta.

- Boa-noite! - disse a terceira carta.

— Olá! - disseram todas as outras, em coro.

- Olá - respondeu o coelho.

E virou-se novamente para o rei: - Vossa Majestade pode fazer a real gentileza de me informar que lugar é este?

- Minha Majestade não pode.

— Mas por que não? Eu perguntei com tanta educação...

- Porque minha Majestade não sabe. Mais alguma pergunta?

— Nós não sabemos! Nós não sabemos! - cantaram as cartas, num coro meio bagunçado.

O coelho detestou a desafinação do coro de cartas. E resolveu seguir adiante.

Foi andando até encontrar um pombo.

— Ora, que animal é este, de orelhas tão compridas? - perguntou o pombo.

- Eu sou um coelho. E você?

- Eu? Eu sou um pombo. O que você está fazendo aqui?

— Não sei muito bem. Aliás, nem sei onde é "aqui".

— Engraçado. Nem eu.

E saiu voando.

— Vejam só! - comentou o coelho. - Não é esse que vai poder me ajudar. Vou em frente.

Ouviu um choro e, seguindo em sua direção, encontrou apenas um lenço caído.

- Deve haver alguém chorando aí embaixo - pensou ele.

E levantou um pouquinho a ponta do lenço. Que estranho, não havia ninguém.

- Então quem é que está chorando?

- Sou eu.

- Eu, quem?

- $\mathrm{O}$ lenço, ora. Tem mais alguém aqui?

O coelho olhou, olhou, e só viu o lenço.

- É, não tem. E por que você está chorando?

- É que eu tenho medo do escuro!

- Você sabe onde fica a saída?

— Não. Eu nem sabia que existe uma saída.

Só de pensar que podia não haver uma saída, o lenço recomeçou a choradeira. 
— Pronto: outro! - pensou o coelho, deixando o lenço para trás.

- Desse jeito vou ter que me virar sozinho.

Lá adiante viu uma claridade no alto.

— Olha!... É um buraco! Vai ver que a saída é por ali.

Voltou e chamou os outros.

— Pombo, você que pode voar, quer ir até lá em cima e ver pra gente se á ali a saída?

O pombo voou, passou pela abertura e sumiu. Os outros esperaram, esperaram, mas ele não voltou.

- Sabe de uma coisa? - disse o rei - Acho que ele não vai voltar. a saída.

— É - concordou o coelho. - Rei, se as cartas subirem uma nos ombros das outras, deve dar para alcançar

As cartas subiram - plim, plim, plom - uma nas outras, fazendo uma espécie de torre.

Aí foi como se tivessem caído pra cima: zip, zap, zup - sumiram todas pelo buraco. Até o rei. E também não voltaram.

- Lenço, tive uma idéia. Eu jogo você até a borda, mas sem largar a ponta. Aí você segura firme, eu vou subindo e nós dois saímos juntos.

O lenço, que era um pouco medroso, ficou na dúvida.

— Será que eu agüento? E se eu rasgar?

- A gente costura. Vamos lá, vai dar certo!

E fizeram deste jeito.

O coelho foi subindo pendurado ao lenço até chegar à abertura.

Demorou um pouco a acostumar a vista porque do outro lado estava tudo muito iluminado.

Antes que pudesse enxergar direito, ouviu uma porção de palmas.

Tinha acabado de sair da cartola de um mágico!

\section{O MENINO MALUQUINHO \\ ZIRALDO}

Era uma vez um menino maluquinho ele tinha o olho maior do que a barriga tinha fogo no rabo

tinha vento nos pés umas pernas enormes

(que davam para abraçar o mundo)

e macaquinhos no sótão

(embora nem soubesse o que significava no sótão).

Ele era um menino impossível!

Ele era muito sabido

ele sabia de tudo

a única coisa que ele não sabia

era como ficar quieto

seu canto

seu riso

seu som

nunca estavam onde ele estava.

Se quebrava um vaso aqui

logo já estava lá

às vezes cantava lá

e logo já estava aqui.
Pra uns, era um uirapuru

pra outros, era um saci.

$\mathrm{Na}$ turma em que

ele andava

ele era

o menorzinho

o mais espertinho

o mais bonitinho

o mais alegrinho

o mais

maluquinho.

Era tantas coisas

terminadas em inho

que os colegas não entendiam

como é que ele podia ser

um companheirão.

Se ele perdia um caderno

no colégio

(e ele perdia um caderno

todo dia)

era fácil encontrar seu dono.

Seu caderno era assim:

um dever e um desenho

$\underline{\text { Descobrimento do Brasil }}$

O Brasil foi descoberto em 1500. Primeiro chamou Ilha de Vera Cruz depois Terra de Santa Cruz mais tarde Brasil. Quem descobriu o Brasil foi o navegante português Pedro Álvares Cabral. Ele saiu do Rio Tejo em Lisboa na frente de uma frota de 13 naus no dia 8 de março de 1500. A 22 de abril ele avistou terra a qual deu o nome de Monte Pascoal, porque era um monte e era Páscoa.

Tem mil perninhas o metro

Eu vou comparar um pernômetro

Pra saber quantas perninhas
Que deve ter num quilômetro

este versinho foi a tia que me ensinou 
Frações decimais dessas unidades são os submúltiplos delas, algumas das quais muito usadas, como o centímetro e o grama.

Mas também se usam medidas que são essas mesmas unidades multiplicadas por 10, 100 ou 1.000.

uma lição e um versinho

um mapa e um passarinho.

"Este caderno só pode ser do menino maluquinho."

a melhor coisa do mundo

na casa do menino maluquinho

era quando ele voltava da escola.

A pasta e os livros

chegavam sempre primeiro

voando na frente.

Depois

entrava o menino

com seu pé de vento

e a casa ventava

os quartos cantavam

e tudo se enchia

de som e alegria.

E a cozinheira dizia:

"Chegou o maluquinho!"

Um dia, num fim de ano

o menino maluquinho

chegou em casa com uma bomba:

"Mamãe, tou aí com uma bomba!"

"meu neto é um subversivo!"

gritou o avô.

"Ele vai matar o gato!"

gritou a avó.

"Tira esse negócio daí!"

falou - de novo - a babá.

Mas, aí o menino explicou:

"A bomba já explodiu, gente.

Lá no colégio."

"Esse menino é maluquinho!"

falou o pai, aliviado.

E foi conferir o boletim.

Esse susto não era nada

tinha outros, que ele pregava.

Às vezes

sem qualquer ordem

do papai e da mamãe

se trancava lá no quarto

e estudava e estudava

e voltava do colégio

com as provas terminadas

tinha dez no boletim

que não acabava mais.

E ele dizia aos pais

cheio de

contentamento

"Só tem um zerinho aí.

Num tal de comportamento!"

Numa noite muita escura

apareceu o fantasma!!!

Coberto com um lençol

muito branco

assustador com dois buracos

nos olhos

saltou

fazendo buuuuuuuuu

sobre os ombros

assustados

do papai e da

mamãe

que voltavam

do cinema.

$\mathrm{O}$ susto não foi

muito, muito grande,

não.

Mas,

com o fantasma

no colo

o papai lhe

perguntou:

"Você não tem medo do escuro?"

E o menino

respondeu:

"Claro que não!

O fantasma sou eu!"

$\mathrm{Na}$ casa do menino maluquinho

era assim:

se tinha chuva

ele queria inventar o sol

pois sabia onde achar

o azul e o amarelo;

se fazia frio

ele tinha uma transa quentinha

pra se aquecer;

se tinha sombras

ele inventava de criar o riso

pois era cheio de graça;

se, de repente,

ficasse muito vazio

ele inventava o abraço

pois sabia onde estavam

os braços que queria;

se havia

o silêncio

ele inventava a conversa

pois havia

sempre

um tempo

para escutar o que menino

gostava

de conversar;

se tinha dor

ele inventava o beijo

aprendido

em várias lições.

E quanto mais

deixavam ele criar 
mais o menino inventava

vestido de

Doutor Silvana

com óculos de aro grosso

e jeito

de maluquinho.

A pipa que

o menino maluquinho soltava

era a mais maluca de todas

rabeava lá no céu

rodopiava adoidado

caía de ponta cabeça

dava tranco e cabeçada

e sua linha cortava

mais que o afiado cerol.

E a pipa

quem fazia

era mesmo o menininho

pois ele havia aprendido

a amarrar linha e taquara

a colar papel de seda

e a fazer com polvilho

o grude para colar

a pipa triangular

como o papai

lhe ensinara

do jeito que havia

aprendido

com o pai

e o pai do pai

do papai.

E quando vinha São João

o mais luminoso balão

que todo mundo apontava

era o gordo balãozinho

do menino maluquinho

que custara uma semana

de trabalho da tesouro

e dos moldes da mamãe.

Era preciso ver

o menino maluquinho

na casa da vovó!

Ele deitava

e rolava

pintava e bordava

e se empanturrava

de bolo e cocada.

E ria

com a boca cheia

e dormia

cansado

no colo da vovó

suspirando de

alegria.

E a vovó dizia:

"Esse meu neto

é tão maluquinho!"

O menino maluquinho

tinha

dez namoradas!
E elas riam muito, muito

de suas graças

riam tanto

que nem tinham tempo

de beijar escondido.

Quando o namoro acabava

e a nova namorada perguntava

qual tinha sido o motivo

do namoro terminar

ela já sabia a resposta:

"Esse seu namorado

é muito maluquinho!"

Mas, todas ficavam muito

apaixonadas!

Ele era um namorado formidável

que desenhava

corações

nos troncos

das árvores

que

desenhava

flores no caderno de desenho

e levava laranjas

e levava maçãs

e pagava sorvetes

e roubava beijinhos

Gosto muito de você

Acho que estou apaixonado

Mas acho que este versinho

Está de pé quebrado

e fazia versinhos

e fazia canções.

E se escalavrava

nos paralelepípedos

e rasgava os fundilhos

no arame da cerca

e tinha tanto esparadrapo

nas canelas

e nos cotovelos

e tanta bandagem

na volta das férias

que todo ano ganhava

dos colegas

no colégio

o apelido de Múmia!

E chorava escondido

se tinha tristezas

e ficava sozinho

brincando no quarto

semanas seguidas

fazendo batalhas

fazendo corridas

desenhando mapas

de terras perdidas

inventando estrelas

e foguetes espaciais.

E era montado

num foguete destes

que ele saía do quarto

a voar outra vez 
pela mesa da sala

pelas grades da varanda

pelas cercas do quintal.

E todo mundo

ficava alegre de novo

ao ver de volta

a alegria da rua!

$\mathrm{O}$ menino maluquinho

tinha lá os seus segredos

e nunca ninguém sabia

os segredos que ele tinha

(pois segredo é justo assim).

tinha uns mais segredáveis.

E outros

que eram

menos.

Tinha uns dez

que ele guardava

só pra contar

pro papai.

E mais uns dez escolhidos

pra dividir com mamãe

Os outros, que eram só dele não dá pra gente saber

nem quantos eram, de fato.

Mas,

o seu maior mistério

todos sabiam de cor

era o jeito

que o menino

tinha de brincar

com o tempo.

Sempre sobrava tempo

pra fazer

mil traquinadas

e data tempo

pra tudo

(o tempo era um amigão)

seu ponteirinho das horas

vai ver

era um ponteirão.

E sobrava tempo

pra ler os gibis

e sobrava tempo

pra colar figurinhas

e para anotar nos livros

de histórias e aventuras

todas aquelas passagens

em que ele virava herói.

O tempo era assim pra ele:

fazia horas a mais.

E o menino maluquinho

era um menino tão querido

era um menino tão amado

que quando deu de acontecer

de o papai ir para um lado

e a mamãe ir pro outro

ele achou de inventar

(pois tinha aprendido a criar)

a Teoria dos Lados!
"Todo lado tem seu lado

Eu sou o meu próprio lado

E posso viver ao lado

Do seu lado, que era meu."

foi uma barra, é verdade.

E é verdade, também

que pouca gente entendeu

a teoria maluca

do menino maluquinho

mas

ele ria baixinho

quando a saudade

apertava

pois descobriu

que

a saudade

era o lado

de um dos lados

da vida

que vinha aí.

Agora, vejam se pode

uma descoberta dessas!

Só mesmo sendo maluco ou sendo amado demais.

$\mathrm{O}$ menino maluquinho

jogava futebol.

E toda a turma

ficava esperando

ele chegar

pra começar o jogo.

É que o time

era cheio de craques

e ninguém queria

ficar no gol.

Só o menino maluquinho

que dizia sempre:

"Deixa comigo!"

E ia rindo pro gol

para o jogo começar.

E o menino maluquinho

voava na bola

e caía de lado

e caía de frente

e caía de pernas pro ar

e caía de bunda no chão

e dançava no espaço

com a bola nas mãos.

E a torcida ria

e gostava de ver

a alegria daquele goleiro.

E todos diziam:

"Que goleiro maluquinho!"

$\mathrm{O}$ menino maluquinho pegava todas!

Mas

teve uma coisa que ele não pôde pegar

não deu pra ele segurar

embora ele soubesse transá-la

como um milagre. 
O menino maluquinho

não conseguiu segurar o tempo!

E aí, o tempo passou.

E, como todo mundo,

o menino maluquinho cresceu.

Cresceu

e virou um cara legal!

Aliás,

virou o cara mais legal

do mundo!

\section{O MENINO QUE ENGOLIU O QUATRO}

José Carlos Aragão. Ilustrações Ricardo Girotto
Mas, um cara legal, $\underline{\text { mesmo! }}$

E foi aí que

todo mundo descobriu

que ele

não tinha sido

um

menino

maluquinho

ele tinha sido era um menino feliz!

Ninguém sabe como foi.

Tudo o que se sabe é que ele engoliu o quatro. Pelo menos, foi o que ele disse.

Mas não disse como foi, e isso foi o suficiente para começarem as especulações.

Teve gente que achou que ele engoliu foi uma carta de baralho, um quatro de coração. Ou de arvorezinha preta.

A mãe dele, quando soube da história do quatro engolido, pensou logo que ele tivesse engolido o dado. Mas não foi, porque o dado não tem só o lado do quatro. $\mathrm{O}$ dado tem mais cinco lados e, se ele tivesse engolido o dado, teria engolido era o 21, que é a soma de todos os lados do dado.

A tia, por sua vez, tirou lá da cachola dela que ele devia ter comido uma pedra de dominó: o duplo quatro.

- Bobagem - disse a outra tia, que tinha cara de bolacha. - Pra mim, esse menino é só um maluquinho, feito aquele do livro...

Depois, o menino apareceu com uma outra história.

De que tinha bebido dois copos de nuvem.

E que, por causa disso, estava com medo de avião sumir dentro dele, quando ele tivesse vontade de chover. Todos riram.

Sem entender o porquê de tanto riso, ele foi brincar no quintal, onde foi atravessado por um passarinho que fazia um vôo rasante.

Todo dia, uma história nova.

Uma vez, ele apareceu contando que tinha andado tanto que chegou até o muro do fim do mundo.

- E é longe? - perguntou o tio que era marido da tia com cara de bolacha.

O menino disse que era longe, muito longe, mas que ele não cansou nem um tiquinho porque, na ida, ele foi pulando sílabas e, na volta, pegou carona num vento contrário.

Todo mundo fingiu que tinha acreditado.

Era sempre assim.

Ou ninguém acreditava ou todos fingiam acreditar.

Como no dia em que ele contou, na escola, que o pai dele era azul.

E desde quando um menino esperto e inteligente como ele - que tinha a coleção completa dos gibis do Tarzã, que nadava que nem peixe, que já sabia amarrar o tênis sozinho, que tinha um cachorro chamado Amigão -, desde quando um menino como aquele podia ter um pai azul?

A professora, é certo que ela fingiu acreditar.

Os coleguinhas, eu não sei. Mas acho que eles ficaram com a professora.

Outro dia, ele contou que encheu de risadas todas as gavetas do armário do seu quarto. Disse que era para ele poder usar quando as risadas acabassem.

Todo mundo riu.

Desesperado, ele saiu catando as risadas de todo mundo. Deu para encher mais uma gaveta. Da cômoda.

Num dia em que o sol apagou de repente e caiu uma chuva forte no meio da tarde, o menino estava gripado, com febre, de cama. Quando a mãe foi ver, outra vez, se a febre já tinha baixado, ele perguntou o que devia fazer se o arco-íris quisesse sair depois da chuva.

- O arco-íris sempre sai depois da chuva, meu filho - disse a mãe.

O menino ficou meio triste com a resposta da mãe e ela quis saber por quê.

Então ele contou que tinha dado o arco-íris pro gato comer.

Não demorou muito e lá vinha o menino com outra história.

De que havia convencido a noite a não sair de cima do pé de manga.

De que seus lápis de cor tinham saído da caixa pra ir a uma festinha de aniversário e, no caminho, coloriram a sala toda de roxo, laranja, cinza e amarelo.

De que o espanador tinha botado um ovo deste tamanho. 
De que as letrinhas do jornal tinham virado pipoca doce.

Uma vez ele esburacou todo o jardim da casa. Disse que era pra plantar música de flauta.

O tempo passou e não nasceu música nenhuma no jardim, só rosa e margarida.

Então ele explicou que a música não vingou porque o dó-ré-mi tinha acabado.

Não sei por que, mas as pessoas nunca perdem a mania de perguntar às crianças o que elas vão ser quando crescerem.

Com o menino não foi diferente.

Um dia, uma das tias tirou da bolsa a pergunta e sapecou:

- E o meu sobrinho querido, quando crescer, vai querer ser o quê?

Se, hesitar, e com a boca toda lambuzada de sorvete de chocolate, o menino falou:

- Eu quero ser um astronauta submarino.

Ficou todo mundo olhando um pra a cara do outro, sem entender.

E olhando pra cara do menino, esperando uma explicação. E ele, enquanto acabava o sorvete, foi explicando que queria viajar numa nave espacial para o fundo do mar, pra explorar as estrelas.

Lá veio a tia com cara de bolacha:

- Mas... as estrelas ficam é no céu...

Aí ele explicou que as estrelas do céu todo mundo já conhecia e que o que ele queria explorar eram as estrelas-do-mar.

O tempo foi passando e aconteceu com o menino o que acontece com quase todo mundo: ele cresceu e virou gente grande.

E, aos poucos, ele foi parando de engolir números, beber nuvem, pegar carona em vento contrário, plantar música ou dar arco-íris pro gato comer.

Também nunca mais falou em ser astronauta submarino.

Ele é meu pai e, hoje, trabalha num banco.

Por isso eu perguntei a ele se o banco podia me emprestar uns milhões, que eu queria comprar uma caixa de manhãs de sol, e o dinheiro da mesada era pouco.

Ele riu muito, me deu um abraço apertado, me colocou na cama e disse que ia me contar uma história: a história do menino que engoliu o quatro.

- Engoliu o quatro? - perguntei. E como é que ele fez isso?

- Ninguém sabe como foi - respondeu meu pai. Tudo o que se sabe é que ele engoliu o quatro.

Pelo menos, foi o que ele disse... 